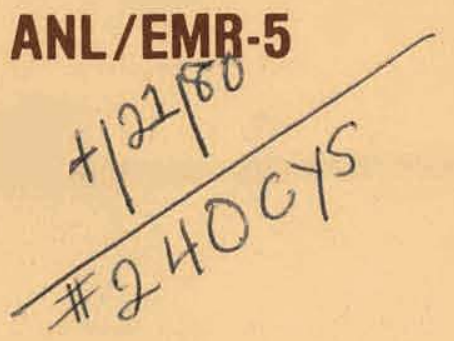

\title{
A BIBLIOGRAPHY OF SELECTED REFERENCES ON THE EFFECTS OF COAL MINE POLLUTANTS ON AQUATIC ECOSYSTEMS
}

\author{
Prepared for the \\ U. S. Department of Energy's \\ Environmental Control Technology Division
}

ENERGY \& MINERAL RESOURCES PROGRAMS

ENERGY \& ENVIRONMENTAL SYSTEMS DIVISION AREONNE NATIONAL LABORATORY 


\section{DISCLAIMER}

This report was prepared as an account of work sponsored by an agency of the United States Government. Neither the United States Government nor any agency Thereof, nor any of their employees, makes any warranty, express or implied, or assumes any legal liability or responsibility for the accuracy, completeness, or usefulness of any information, apparatus, product, or process disclosed, or represents that its use would not infringe privately owned rights. Reference herein to any specific commercial product, process, or service by trade name, trademark, manufacturer, or otherwise does not necessarily constitute or imply its endorsement, recommendation, or favoring by the United States Government or any agency thereof. The views and opinions of authors expressed herein do not necessarily state or reflect those of the United States Government or any agency thereof. 


\section{DISCLAIMER}

Portions of this document may be illegible in electronic image products. Images are produced from the best available original document. 
The facilities of Argonne National Laboratory are owned by the United States Government. Under the terms of a contract (W-31-109-Eng-38) among the U. S. Department of Energy, Argonne Universities Association and The University of Chicago, the University employs the staff and operates the Laboratory in accordance with policies and programs formulated, approved and reviewed by the Association.

\section{MEMBERS OF ARGONNE UNIVERSITIES ASSOCIATION}

The University of Arizona

Carnegie-Mellon University

Case Western Reserve University

The University of Chicago

University of Cincinnati

Illinois Institute of Technology

University of Illinois

Indiana University

The University of Iowa

Iowa State University
The University of Kansas

Kansas State University

Loyola University of Chicago

Marquette University

The University of Michigan

Michigan State University

University of Minnesota

University of Missouri

Northwestern University

University of Notre Dame
The Ohio State University

Ohio University

The Pennsylvania State University

Purdue University

Saint Louis University

Southern Illinois University

The University of Texas at Austin

Washington University

Wayne State University

The University of Wisconsin-Madison

\section{NOTICE}

This report was prepared as an account of work sponsored by an agency of the United States Government. Neither the United States Government or any agency thereof, nor any of their employees, make any warranty, express or implied, or assume any legal liability or responsibility for the accuracy, completeness, or usefulness of any information, apparatus, product, or process disclosed, or represent that its use would not infringe privately owned rights. Reference herein to any specific commercial product, process, or service by trade name, mark, manufacturer, or otherwise, does not necessarily constitute or imply its endorsement, recommendation, or favoring by the United States Government or any agency thereof. The views and opinions of authors expressed herein do not necessarily state or reflect those of the United States Government or any agency thereof.

Printed in the United States of America

Available from

National Technical Information Service

U. S. Department of Commerce

5285 Port Royal Road

Springfield, VA 22161

NTIS price codes

Printed copy: A12

Microfiche copy: A01 
Distribution Category:

Environmental Control Technology and Earth Sciences (UC-11)

ANL/EMR-5

Argonne National Laboratory

9700 South Cass Avenue

Argonne, Illinois 60439

\section{A BIBLIOGRAPHY OF SELECTED REFERENCES \\ ON THE EFFECTS OF COAL MINE POLLUTANTS \\ ON AQUATIC ECOSYSTEMS}

by

Thomas F. Daniels, Lynell K. Daniels, Richard D. O1sen, * and Donald.O. Johnson

Energy and Environmental Systems Division

December 1979

DISCLAIMER

Neither the United States Government nork sponsored by an agency of the Unitred States Governfnent. warranty. express or imolied, or assumes agency thereof, nor any of their employees, makes any completeness, or usetulness of any informy legal liability of responsibility for the accuracy. represents that its use would mi intring prion, apparatus, product, or process disctosed, or commercial product. process, or service by rode ormed rights. Reference herein 10 any soecific nol necesserily constitute or imoly its endoremom. Hadenerk, manufacturer, or otherwise, does Steles Government or any agency thereof. The vius. necessarily state or reflect those of the Unized States Government or authors expressed herein do not

Work sponsored by

Envi ronmental Control. Technology Division

Assistant Secretary for Environment

United States Department of Energy 
ACKNOWLEDGMENTS . . . . . . . . . . . . . . . . . . . v v

ABSTRACT . . . . . . . . . . . . . . . . . . . . . . 1

INTRODUCTION . . . . . . . . . . . . . . . . . . . . . 1

BIBLIOGRAPHIES . . . . . . . . . . . . . . . . . . . . 3

GENERAL REFERENCES . . . . . . . . . . . . . . . . . . . . . . . 7

REFERENCES FOR INDIVIDUAL PARAMETERS . . . . . . . . . . . . . . 59

Acidity . . . . . . . . . . . . . . . . . 59

Alkalinity . . . . . . . . . . . . . . . . 66

Alumi num ...................... . . . 68

Ammonia . . . . . . . . . . . . . . . . . . 70

Ant imony . . . . . . . . . . . . . . . . . . . . 75

Arsenic . . . . . . . . . . . . . . . 76

Bariun . . . . . . . . . . . . . . . . . 79

Beryllium . . . . . . . . . . . . . . . . . . 80

Boron ......................... 80

Cadmium . . . . . . . . . . . . . . . . . . . $B 1$

Calcium . . . . . . . . . . . . . . . . . 95

Chloride . . . . . . . . . . . . . . . . . . . 97

Chromium . . . . . . . . . . . . . . . . . . . 98

Cobalt... . . . . . . . . . . . . . . . 105

Copper . . . . . . . . . . . . . . . . . . . . 107

Cyanide . . . . . . . . . . . . . . . . . . . . 128

Dissolved Solid̈s - Salinity . . . . . . . . . . . . . 130

Fluoride . . . . . . . . . . . . . . . . . . . . . 136

Hardness (Total)................... . . . 137

Iron . . . . . . . . . . . . . . . . . . . . 141

Lead . . . . . . . . . . . . . . . . . . . . 145

Magnesium . . . . . . . . . . . . . . . . . . . . 154

Manganese . . . . . . . . . . . . . . . . . . . 155

Mercury ....................... . . 158

Molybdenum . . . . . . . . . . . . . . . . . . . 178 
Nickel . . . . . . . . . . . . . . . . . 180

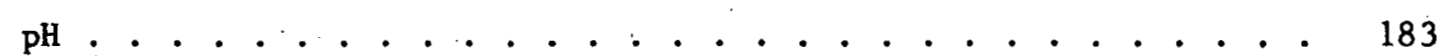

Pheno1 . . . . . . . . . . . . . . . . . . . 189

Potassium . . . . . . . . . . . . . . . . . . 194

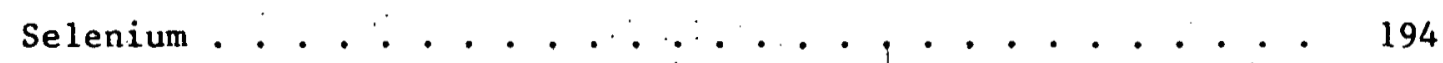

Silver :............, . . . . . . . , . 197

Sodium . . . . . . . . . . . . . . . . . . 199

strontium ....................... . . 199

Sulfate ...................... . . . 200

Sulfide . . . . . . . . . . . . . . . . . 201

Sulfur . . . . . . . . . . . . . . . . . . . . . . 203

Suspended Solids . . . . . . . . . . . . . . . . . . 203

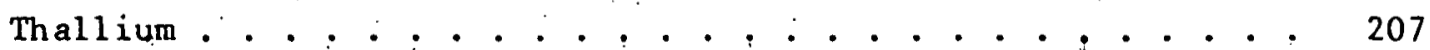

Vanadium .......................... 208

Zinc............................. . . 208

AUTHOR INDEX . . . . . . . . . . . . . . . . . . . . . 229 
The authors would like to acknowledge the invaluable assistance of the individuals listed below.

We thank editors Charles A. Malefyt and Priscilla Grundy for their careful critique, and Maureen Mulroy, Cheryl Archer, and the other Technical Information Services staff at Argonne for their assistance in collecting'data and improving format.

We are especially. grateful to John E. Reiter, and also to Ronald R. MacDonald and Paul R. Smedinghoff, for helpful guidance with the computer systems used in compilation and editing. Madeline Antos was extremely helpful in entering and manipulating references in the WYLBUR text-editing system.

Finally, our thanks to Karen Bfink and Betty Carli for their help in formatting and compilation.

Without the support of these individuals, completion of this bibliography would have been virtually impossible. 


\begin{abstract}
A BIBLIOGRAPHY OF SELECTED REFERENCES
ON THE EFFECTS OF COAL MINE POLLUTANTS

ON AQUATIC ECOSYSTEMS
\end{abstract}

by

Thomas F. Daniels, Lynell K. Daniels, Richard D. Olsen, and Donald 0 . Johnson

\begin{abstract}
This bibliography contains more than 1400 references dealing with field and laboratory research on potential toxicities and disturbances known or postulated to be caused by pollutants found in coal mine effluents. The first of the three sections into which the bibliography is divided contains a select list of published bibliographies and literature reviews. In the second section are references on mine drainage studies, general references on environmental pollutants, and references dealing with two or more specific parameters. The third section includes references for 40 parameters under individual parameter headings. The multi-parameter references in the second section are therefore also listed in the third section under individual headings. An author index is also provided.
\end{abstract}

\title{
INTRODUCTION
}

During the compilation and review of published literature concerning the effects of coal mine pollutants on aquatic ecosystems for Argonne's Environmental Control Technology Program, the need for collation of the information became apparent. Although a number of bibliographies dealing with pollutant toxicities have been published (see Bibliographies section), none has been specifically oriented toward pollutants associated with coal mining and processing. The majority of the information concerning coal effluents was in the form of individual reports or journal articles. Therefore, as part of the Environmental Control Technology Program, a bibliography of the references collected for the project.was prepared. While this bibliography is. not exhaustive, it provides a reference base for researchers and decision-makers conducting assessments of the effects of coal mine pollutants on aquatic ecosystems. 
THIS PAGE

\section{WAS INTENTIONALLY LEFT BLANK}




\section{BIBL I OGR A PHIES}

Becker. C.D.e "Aquatic Bioenvironmental studies in the columbia $P i$ ier at Eanford 1945-1971, A Bibliography with Abstracts," Battelle Pacific Northest Iabosatories, Richland, Hash.. BNGL-173 is (1973).

Clarke. R. MCV.. "The Effects of Effluents from Metal Mines ou Aguaric Bcosystems in Canada," A Iiterature Revier, Department of the Enyirongent, Resource Management Branch, Fish and Marine Service Research and Development Directorate, Technical Report Ho. 488, innipeg, Manitoba, 150 pp. (1974).

Copenhaver, E.D., et al.; "Arsenic in the Environment: An Annotated Bibliography," Oak Ridge National Laboratory, Tenn.. ORNL-EIS-73-16, 304 pp. (1973) .

Copenhaver, E.D.. et al. "Cadmium in the Environment: A Annotated Bibliography," Oak Ridge National Laboratory, Tenn., ORNI-EIS-73-17, $444 \mathrm{pp}$. (1973).

Gapowskyj. M.M. "Annotated Bibliography on the Foology and Reclaration of Drastically Disturbed Areas," U.S. Departuent of Bgriculture Porest Service General. Technical Report NE-21, NE Forest Experiment Station, Upper Darby, Penn.. 98 Pp. (1976).

Doudoroff, P. and M. Ratz, "Critical Review of Literature on the Toxicity of Industrial Hastes and Their components to Fish II, The Metals, as Salts," Sewage and Industrial wastes, $25(7): 802-839(1953)$.

Disler, R.. "Apnotated Bibliography on Biological Effects of aetals in auatic Environments," U, $S_{c}$ Environantal protection Agency, BCological Research. Series EPA-R3-73-007, 287 PP. (9973)。

Eisler, R. and M. Napper, "Secord Ennotated Bibliography on Biological Effects of Metals in aguatic Environments," 0.s. Environaental Protection Agency Beport EPA-600/3-75.008 (1975).

Gleason, V.E. and H.H. Russell, "Coal and the Environment Abstract Series: Mine Drainage Bibliography 1910-1976," Biturinous Coal Research, Inc., Monroeville, Penn.. 288 pp. (1976)。

Glenn-Lewin, D.C. et al.. "Bibliography of Strip Mine Ecology." Iowa state oniversity, Energy and Hineral Resources Research Institute Report No. IS-ICP-20 (1970). 
Great Lakes Laboratory, "Chromium, Cadmium, Arsenic, Selenium, Mercury, and Aquatic Life: A Brief Iiterature Review," state University College at Buffalo, N.Y.. Special Report No. 9 (1971).

Harrison, E.A., (ed.), "Bioindicators of Pollution (A Bibliography with abstracts)." Covering 1964-1976 (Oct. 1976). (NTIS PS-76/0868)

Keeney, D.R., "Pate of Nitrogen in Aquatic Bcosystems," Eutrophication Information Progran, Literature Review No. 3, University of Wisconsin Water Fesource Center, Madison (1972). (NTIS PB-209 217)

LaRiviere, M.G., Et al.." A Bibliography on Cycling of rrace Hetals in Freshwater Ecosystems," Battelle pacific Northwest Laboratory. Richland, Wash., PNI-2706 (1978).

Maynard, E.A.. M.I. Downa, and M.F. LaSher, "Occurrence and Biological Effects of Fluorine Compounds," Annotated

Bibliography, Kettering Laboratory, University of Cincinnati, Ohio (1958).

Natural Resource Ecology Laboratory, "Ecological Effects of coal Strip Mining: A Bibliography with Abstracts," Interagency Energy-Environment Research and Development Program Report, Colorado state noiversity, Fort Collins (Macch 1977) . (NTIS Fis/OBS-77/09)

Office of Water Resources Research, "Chromium in Hater: A Bibliography,"U.S. Department of the Interior, Hashington, D.C.. WRSIC 72-205 (1972).

Office of water Research and Technology, "Acid Mine Water, A Bibliography," U.S. Department of the Interior, Hashington, D.C., WRSIC 75-202, 564 pP. (1975) . (NTIS PB-239 523)

Office of Hater Research and Technology, "Heavy Metals in Water (Excluding Mercury), A Bibliograpby, Volume 1," Report No. OWRT/WRSIC 77-201, U.S. Department of Commerce, NTIS,

Springfield. Va. (1977) .

Office of Hater Research and Technology. "Heavy Metals in Water (Excluding Mercury). A Bibliography. Volume 2,"Report No. OWRT/WRSIC 77-205, U.S. Department of Commerce, NTIS, Springfield, Va. (1977).

Office of water Research and Technology, "Heavy Metals in water (Excluding Mercury). A Bibliography, Volume 3," Report No. OWRT/NRSIC 77-206, U.S: Department of Commerce. NTIS. Springfield, Va. (1977). 
office of Water Research and Technology, "Heavy Metals in water (Excluding Mercury). A Bibliography. Volume 4." Report No. OWRT/WRIC 77-207, J'S. Department of Commerce, NTIS, springfield, Va. (1977).

Office of Mater Research and Technology, "Heavy Metais in water (Excluding Mercury). A Bibliography. Volume 5." Report No. OWRT/WRSIC 77-208, U.S. Department of Commerce, NTIS, Springfield, $\forall a .(1977)$.

Office of Water Research and Technology, "Mercury in hater, A Bibliography, Volume 2, Washington,.D.C. (Hay 1975). (NTIS $P B-242940.1$

Office of Hater Research anj Technology, "Mercury in Hater. A Bibliography, Volume 3," Report No. OWRT/WRSIC 77-202, U.S. Department of Commerce, NTIS, Springfield, Va. (1977).

Parsons; J.H:, "Reference Material on 'Acia Coal line Pollution and Related Subjects," (A selected Bibliography). Journal. of the Tennessee Academy of Science. 28(2):161-162 (1953).

Ralston, Si, et al.." The Ecological Effects of Coal Strip-Mining: A Bibliography with Abstracts," Report No. FWS/OBS-77/09, U.S. Department of the Interior, Office Research and Development, Fish and Vildife Service, Ft. Collins, Colo. $(1977)$.

Robinson, S. and H.B. Scott, "A Selected Bibliography on Hg in the Environment, with subject Listing," The Foyal ontario Museum, Toronto, (1974).

Rudolfs, W.. et al.. "Review of Literature on Toxic Materials Affecting sewage Treatment Processes, Streams, and B.O.D. Determinations," Sewage and Industrial Wastes, $22(9): 1157-1164$ (1950).

Sil1s. J.B.. "A Feview of the Iiterature on the Use of Lime [ $\mathrm{Ca}(\mathrm{OH}) 2, \mathrm{CaO}, \mathrm{CaCO3}]$ in Fisheries," (1974). (NTIS PB-235-449)

Sinha, F.. "Metals as pollutants in Air and Mater: An Anotated Bibliography," Ocean Engineering Information Service, LaJolla, C.alif. (1972).

0.S. Department of the Interior. "Trace Elements in water - A Bibliography," office of Water Resources Research Report HRIC 71-202, 286 pp. (June 19971) - (NTIS PB 201266 )

0.S. Department of the Interior, "Copper in water - A Bibliography," office of Water Resources Research Report WRSIC 71-204, $189 \mathrm{pp}$. (July 1971). (NTIS PB 201269 ) 
U. S. Departoent of phe Interior. "Magnesium in Water Bibliography;" office of hater Resources Research Report; HRIC $790206,152 \mathrm{pP} .(\mathrm{JQ1Y} 9971)=($ NTIS No: PB 201271 )

0.5. Deparenent of the Interioro "Manganese in Hater - A Bibliography;" Dffice of hater Resources Research Report WRSIC $71-205,127 \mathrm{pp}$. (Jul\$ 1371). (NTIS NO. PB 201270 )

G.S. Department of the Interior, "zinc in water - A Bibliography," office of yater Resources Research Report HRIC $71-208_{8} \quad 138 \mathrm{pp}$. (July 1971) . (NTIS PB 201272 )

U.S. Departwent of the Interior, "Arsenic and Lead in Hater Bibliography." Office of Hater Resources Research Report HRSIC 71-209.82 pp. (Sept. 1971) - (NTIS PB 202 578)

U.S. Department of the Interior, "Hercury in Hater - A Bibliography." Vol. I. Office of Vater Resource Research Report URSIC 72-207, 294 pp. (Jan. 1972). (NTIS PB-206-535)

U.S. Department of the Interior "Chromiumin hater - A Bibliography," Office of Hater Resources Researcb Report WRSIC 72-205, $126 \mathrm{pP}$. (June 1972) - (NTIS PB 210 92.1)

U. S. Department of the Interior, "gercury in water - A Bibliography。 Vol. II.: Office of Water Research and Technology Report 0 gRT/ARSIC 75-203,338 pp. (Hay 1975) . (NTIS PB-242-940)

U.S. Department of the Interior, "Mercury in Water - A Bibljogr aphy "Vol. JII. office of Vater Research and Technology Report OURTfBSIC 77-202, 169 po. (April 1977):(NTIS PB-267-079)

T.S. Fryisonental protection Agency, "Biological Aspects of Lead: Ar canotated Bibliography " superintendent of Documents. U.S. Gorerisment PIinting office, washington, D.C., 20402 (1972). $(A P=10$ แ

Hater kesources Scientific Information Center, "Cadmium in Water - Bjbliography," office of Rater Resources Research, U.S. Departien of the Interior, Report No. WRSIC-73-209, 231 pp. $(9973)$.

Wells, P.G., "A Selected Bibliography on Rainbow Trout (Sa gairdneri Richardson) uith particular Reference to studies with Aguatic Joxicants," Report No. EPS-3-AR-77-1, Environmental protection Service Department, Fisheries and Environment, Halifax, Nova Scotia, Canada (1977)..'1 
GENERAL REFERPNCES

Abbott, O.J.. "The Toxicity of Ammonium Molybdate to Marine Invertebrates," Marine Pollution Bulletin, 8:204 (1977).

Academy of Natural Sciences, "The Sensitivity of Aquatic Life to Certair Chemicals comonly Found In Industrial Hastes,"

Philidelphia, Penn. (1960).

adelman, I.R...I. L. Smith, Jr.., and G.D. Siesennop, "Acute Toxicity of Sodium Chloride, Pentachlorophenol, Guthion, and Hexaralent Chromium to Fathead Minnows (ㅁimenhales promelas and

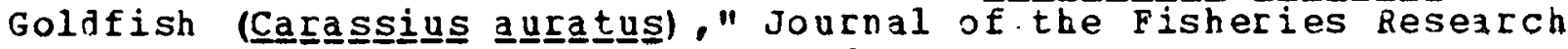
Board of Canada, $33(2): 203-208$ (1976).

Atsanullah, M.; "Acute Toxicity of Cadmium and Zinc to seven Irvertebrate Species from Hestern Port, Victoria," Australian Journal of Marine and Freshwater Research, 27 (2):187-196 (1976).

Alekseenko, V.A., et a l.." "Higration of Lead and zinc in surface waters During the Sharp Enrichment ot the Waters with sulfides of the Metals," Izvestiya Akademii Nauk Kazakhskoi SSR, Seriya. Geologich eskaya (USSR), $30(2): 76$ (1973): Chemical Abstracts, $79: 209$ (1973).

Amiard, J.C., "Phototactic Variations in Crustacean Larvae Due to Diverse Metallic Pollutants: Demonstrated by a Sublethal Toxicity Test," Marine Biology, 34:239 (197E).

Anderson, B.G.. "Toxicity Threshold of Various substances Found

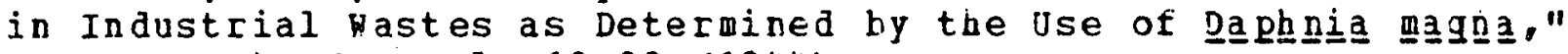
Sewage Works. Journal, 18:32 (1944).

Andersoa, B.G., "Apparent Thresholds of Toxicity to Da for Chlorides of various Metals when Added to lake Erie Water." Transactions of the American Fisheries Society, 78:96-113 (1950).

Anderson, B.A." et al.." "Survival and Growth of Tannyta dissimilas (Chronomidae) Exposed to Copper, cadmium, zinc, and Nickel." National Environmental Fesearch Laboratory, Duluth, Minn., Quarterly Feports (1975).

Anderson, R.V., "Cadmium, Copper, Lead, and zinc: Tracemetal Pollutants in an Bquatic Fcosystem," NSF-SOS Grant GY-10314 Final Report. National Science Foundation, Washington, D.C., 275 pp. (1973). 
Anderson, R.V.. "The Occurrence of Cadminm, Copper, Lead, and Zinc in Macroinvertebrates of the Pox River, Illinois," Unpublished . S. thesis, Department of Biological science, Northern Illinois University. DeKalb, 134 pp. (1975).

Anderson, R.V.. "Concentration of Cadmium, Copper, Lead, and zinc in Thirty-Five Genera of Freshwater Macroinvertebrates from the Pox River. Illinois and Wisconsin," Bulletin of Environmental Contamination and Toxicology, 18(3):345-349 (1977).

Anderson, R. V.. "Concentration of Cadmium, Copper, Lead and zinc in Six Species of Erestwater Clams," Bulletin of Environmental Contamination and Toxicology, $18(4): 492$ (1977).

Andrew, R.W.., et a 1.. (ed.), "Toxicity to Biota of Metal porms in vatural Naters". Proceedings of the International Joint Commission Great Iakes Research Advisory Board Rorkshop, Duluth, Minn. 329 pp. (1976).

Anwar, R.A., C.A. Hoppert, and R.U. Byercum, "Toxicity studies on Cadmium and Hexavalent Chromium," Nater and Serage Works, 107:465 $(1960)$.

Appalachian Pegional Commission, "Acid line-Drainage in Appalachia," U.S. Government Printing office, Hashington, D.C. (1969).

Appelgate, V.C.. et al.. "Toxicity of 4,346 Chemicals to Larval Lampreys and Fishes," O.S. Fish and Wildife Service, special Scientific Report--Fisheries, No. 207. 157 pp. (1957).

Aubert, M., et al., "סtilization of a Trophodynamic Chain of a Pelagic Type for the study of Transfer of Metallic pollution," Revue Internationale d'oceanographie Medicale, 28:27-52 (1972).

Aubert, M., et al., "Ose of a Neritic Trophodynamic Chain of Molluscs for the study of the Transfer of Metallic pollutants," 6th Symposium of the Internationale d oceanographie Medicale, Portoroz, Yugoslavia (Sept. 26-30, 1973); Revue Internationale d'oceanographie Medicale, 33:7-30 (1973). (NTIS CONF-7309103-1)

Barica, J.. M.P. Stainton, and A.L. Hamilton, "Mobilization of Some Hetals in water and Animal Tissue by NTA, EDTA and TPP," Water Research, 7:1791-1804 (1973).

Barnes, H. and F.A. Standbury, "Toxic Action of Copper and Mercury Salts Both Separately and when Mixed on the Harpactacid Copepod Nitoc들 spinines (Boeck)," Journal of Experimental. Bioiogy, 25:270-275 (1948).

Barsdate, R.J., "Pathways of Trace Elements in Arctic Lake Ecosystems," "Iniversity of Alaska; Fairbanks, Institute of Marine science (1972). (NTIS R.LO-2229-T2-1) 
Bartlett, I., F.W. Rabe, and W.H. Funk, "Effects of Copper, zinc

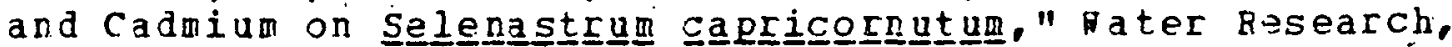
$8(3): 179-185(1974)$.

Battelle Pacieic Northwest Laboratories, "A comparison of tha Lethality of Various Combinations of Heavy Metals and Water Temperature to Juvenile Rainbow Trout," 5 pp. (1973). (NTIS $B N W L-S A-4704)$

Beamish, R.J. and J.C. VanLoon, "precipitation Loading of Acid and Heary Metals to a Small Acid Iake Near Sudbury, Ontario," Journal of the Fisheries Research Board of Canada, 34:649-558 (1977) .

Beamish, R.J., et a1., "An Examination of the Possible Effects of Sudbury Nickel Mining and Smelting operations on Fishes and water Chemistry of Lakes Hithin the Witefish Lake Indian Reserve," U.S. Fisheries and Marire Service Fesearch Division, Technical Report No. 579, 52 pp. (1975).

Becker, C.D.. "gquatic Eioenvironmental studies in the Columbia River at Hanford 1945-1971, A Bibliography with Abstracts," Battelle Pacific Northwest Lahoratories, Richland, Wash., BNWJ, -1734 (1973) .

Becker, C.D. and T.O. Thatcher, (compilers), "Toxicity of Power Plant Chemicals To Aquatic Life," Peport for United stat es Atomic Energy Commission, Battelle Pacific Northwest Laboratories, Richland, Wash. WASH-1249 (1973).

Benes, P. and E. Steinnes, "Migration Forms of Trace Blements in Natural Fresh Waters and the Effect of the Water Storage," Water Research, 9:741-749(1974).

Benjfts-claus, C. and F. Benijts, "Effect of Low lead and zinc Concentrations on the Larval Development of the Mudcrad

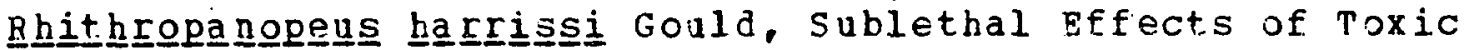
Chemicals on Aquatic Animals," Proceedings of the Swedish-Netherlands Symposium, Wageningen, Neth., 43 (1975).

Bentley-Mowat, J.A. and S.M. Reed, "Survival of Marine Phytoplankton in High Concentrations of Heary Metals, and Uptake of Copper:" Journal of Experimental Marine Biology and Ecology, $26: 249(1977)$.

Eerland, B.R.., et al., "Toxic Effects of Four Heavy Metals on the Growth of Unicellular Marine Algae." Comptes Fendus Hebdomadaires des Seances de l'Academie des Sciences, Serie D: Sciences Naturelles, 282:63j (1976).

Biesecker. J.E. and J.R. George. "Stream ouality in Appalachia as Related to Coa1-Mine Drainage, 19,65," In: Water Quality in a Stressed Environment, W. A. Pettyjohn, (ed.), Burgess, Minneapolis, pp. 45-60 (1972). 
Biesinger, K.E. and G.M. Christensen, "Effects of Various Metals on Survival, Growth, Reproduction, and Metabolism of Daphnia magna ," Journal of the Fisheries Besearch Board of Canada, 29(12): 1691-1700 (1972).

Bilinski, E. and E.E.E. Jonas, "Effects of Cadming and Copper on the oxidation of lactate by Rainbow Trout (Salmo gairdneri) Gills." Journal of the Fisheries Research Board of Canada. $30(10): 1553-1558$ (oct. 1973).

Birge, M.J. and J.J. Just, "Sensitivity of Vertebrate Embryos To Heavy Metals as a Criterion of water Quajity, " Kentucky ater Resources Institute, Lexington (1973). (NTIS PB-226-850)

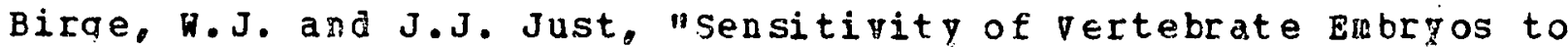
Heary Metals as a Criterion of Hater Quaiity, phase II: Bioassay procedures Using Developmental stages as Test Organisms " kentucky hater Resources Institute, Lexinqton, Report NO. RR-84 (Narch 3975 ). (NTIS PB-240 978, RL)

Birge, H.J., A.G. Mesterman, and 0.R. Roberts, "Lethal and Teratogenic Effects of Metalic Pollutants on Vertebrate Embryos," Trace Contaninants in the Environment, Proceedings of the 2 nd Annual NSF-RAN rrace Contaminants Conference, Asilomarp Pacific Grove, Calif. (Aug. 29-31, 1974).

Birge, W.J., et al.. "Sensitivity of Vertebrate Embryos to Heavy Metals as a criterion of pater Quality. Phase I," Kentucky Water Resources Institute, Lexington (i974). (NTIS PB-226-850/LL)

Birge, H.J., et al.. "Sensitivity of Vertebrate Embryos to Heavy Metals as a Criterion of Water Quality. Phase IIIs Ose of Fish and Amphibian Eggs and Embryos as Bioindicator organisus for. Evaluating Water. Quality。" Kentucky Water Resources Researeh Institute, Lexington, Report RR-91 (Jan, 1976). (NTIS PB-250) 404/IST)

Birge, WoJ., er a $1 .$. "Erbryopathic Effects of waterborne and Sediment-Accumulated Cadmium, hercury, and zinc on Reproduction and Survival of Fish and Amphibian populations in Kentucky." Research Report 100, Water Resources Research Institute, University of Kentucky, Lexington, $28 \mathrm{pp}$. (1977); ONT/A-061-KT(1), D.S. Department of commerce, NTIS, springfield, Va. (1977).

Blaylock, B.G., et al., "Ecoloqy of Toxic Metals," Ecology and Analysis of Trace Contaminants, Oak Ridge National Laboratory Progress Report 1973, pp. 140-175 (1974).

Boccardy, J.A. and W.M. Spaulding, Jr., "Effects of Surface Mining on Fish and Wildife in Appalachia," U.S. Bureau of sport. Fisheries, and wildlife Resources Publication No. 65, 20 pp. $(1968)$. 
Bondietti, E.A., et a 1., "Ecological Research," Ecology and Analysis of Trace contaminants, progress Report. October 1974-December 1975, W. D. Shults and R.I. Van Hook, (eds.), Oak Rj.dge National Latoratory he port ORNL-NSF-EATC-22 (1976).

Boothe, P.N. and G.A. Knauer, "Possible Importance of Fecal Material in the Biological Amplification of Trace and Heavy Metals," Limnoloqy and Oceanography, 17(2):270-275 (1972).

Bothner, M.H. ard R. Carpenter, "Sorption-Desorption Beactions of Mercury ith suspended Hatter in the Columbia Rivero". Presented at the International atomic Energy Aqency symposium on the Interaction of Badioactive contaminants with the constituents of the Marine Environment, Seattle, (July 10-14, 1972).

Bovee, E.C.. "Effects of Certain Chemical Pollutants on Small Aquatic Animals," Kansas Nater Resources Research Institute, Manbattan (Jan. 1975) . (NTIS PB-241336)

Bovee, R.C., "Efferts of Selected Chemicals op Movenent, Growh, and Survival of Certain Aquatic Animal Life," National Technical In formation Service, Re port No. PB-261.388 (1976).

Bowen, H.J.M., "Trace Elements in Biochemistry," Academic Press, New York, 241 pp. (1966).

Boyden, C.R.. "Accumulation of Heavy Metals by Shellfish" Proceedings of the $4 \mathrm{th}$. Shellfish Conference, Shellfish

association of Great Britain, pp. 38-48. (1973).

Boyden, C.R., "Trace Element Content and Body size in Molluscs," Nature, $251: 311-314$ (1974).

Boyden, C.R. and.M.G. Romeril, "A Trace Metal. Problem in Pond oyster Culture," Marine Pollution Eulletin, 5:74-78 (1974).

Boyer, J.F. and V.E. Gleason. "Coal ard Coal Mine Drainage," Journal of the wator pollution Control Federation, $49(6): 1163-1172$ (1977).

Braek, G.S.G.. A. Jensen, and A. Mohus, "Heavy Metal Tolerance of Marine Phytoplankton III. Combined Effects of Copper and Zinc Ions on Cultures of Four Common Species," Journal of Experimental Marine Biology and Ecology, 25(1):37-50 (1976).

Branson, B.A. and D.I. Batch, "Effects of Strip Mining on Smal1-stream Pishes in East-Central Kentucky, "Proceedings of the Biological Society of Washington, 84:507-517 (1972).

Branson, B.A. and D.I. Batch, "Additional observations or the Effects of Strip inina on small-stream. Fishes in East-Central Kentucky," Transactions of the Kentucky Academy of Science $35(3-4): 81-83(1974)$. 
Bremmer, I:, "Heavy-Metal Toxicities," Quarterly Review of Biophysics, $7: 75-124(1974)$.

Brezina, E.R., R.S. Cambell, and J.R. Whitley. "Fffects of Acid Mine Drainage on Water Quality of a Reservoir " Journal of the water Pollution Control Federation, 4:1429 (1972).

Bringmann, G. and R. Kuhn, "The Toxic Effects of Waste Water on Aquatic Bacteria, Algae, and Small Crustaceans,"

Gesundbeits-Ingenieur, 80:115 (1959).

Bringmann, G. and $R$. Kuhn, "yater Toxicity studies with

Protozoans as Test Organisms," Gesundheits-Ingenieur, $80: 239$

(1959).

Brkovic-Popovic, I. and M. Popovic, "Effects of Heavy Metals on Survival and Respiration Rate of Tubificid worms: Part I Effects on Survival," Environmental Pollution, 13:65-72 (1977).

Brkovic-popovic, I. and M. Popovic, "Effects of Heary Metals on Survival and Respiration Rate of Tubificid Horms: Part II -

Effects on Respiration Rate," Environmental Pollution, 13:93-98 $(1977)$.

Brown, B.E., "Observations on the Tolerance of the Isopod Asel $\underline{1} \underline{\underline{u}} \underline{\underline{s}}$

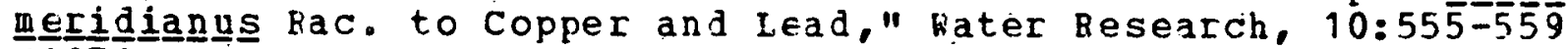
$(1976)$.

Brown, B.E.. "Effects of Mine Drainage on the River Hayle, Cornwall: A) Factors Affecting Concentrations of Copper, Zinc and Iron in water, Sediments and Dominant Invertebrate Pauna," Hyarobiologia, $52(2 / 3): 221-233$ (1977): Blological Abstracts, $13612,(1977)$.

Brown, B.E.. "Uptake of Copper and Lead by a Metal-Tolerant Isopod Aselilus meridianus Rac." "Freshwater Bioloqy. 7 (3):235-244 (1977).

Brown, B.E. and R.C. Newell, "Effect cf Copper and 7 inc on the

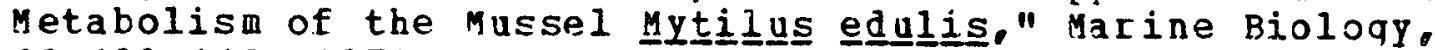
$16: 108-118$ (1972).

Brown, V.M." "The Calculation of the Acute Toxicity of Mixtures of Poison to Bainbow Trout," Water Research, 2(10):723-733

$(1968)$.

Brown, V.M.. "Aspects of Heavy Metals Toxicity in Fresh Waters," Proceedings of the International Joint Commission's horkshop on Toxicity to Biota of Metal Forms in Natural water, october 7-8, 1975, Duluth, Minn.. pp. 59-75 (April.1976).

Brown, V.M. and R.A. Dalton, "The Acute Lethal Toxicity to kainbow Trout of Mixtures of Copper, Phenol, Zinc and Nickel," Journal of Fisheries Biology, 2:211-216 (1970). 
Brown, V.A., D.G. Shurben, and D. Shaw, "Studies on Water Quality and the Absence of Fish From Some Polluted Englisb Fivers," hater Research, 4:363-382 (1970).

Brown, V.M., B.A. Tiller, and D.H.M. Jordan, "Acute Toxicity to Rainbow Trout of Fluctuating concentrations and Mixtures of Ammonia, Phenol, and Zinc," Journal of Fish Biology, 1:1-9 $(1969)$.

Browning, E., "Toxicity of Industrial Metals," Buttervorths, London, 383 pp. (1969).

Brunqs, W. A., et al., "Effects of pollution on Freshwater Fish;" Journal of the Nater pollution Control Federation, $49(6): 1425-1493$ (1977).

Bryan, G.W., "Zinc Regulation in the Freshwater Crayfish (Including some Comparative Copper Analyses)," Journal of Experimental Biology, 46:281-296 (1967).

Bryan, G. M.. "Effects of Heavy Metals (Other than Mercury) on Marine and Estuarine organisms," Proceedings of the Royal society of London, 177:389-410 (1971).

Bryan. G.H., "Occurrence and Seasonal Variation of Trace Metals

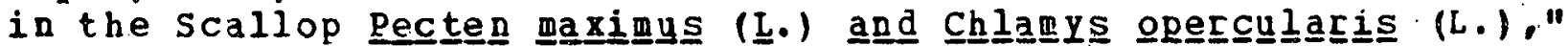
Journal of the Marine Biological Association of the United Kingdom, 53:145-166 (1973).

Bryan, G.H., "Adaptation of an Estuarine Polychaete to sediments Containing High Concentrations of Peavy Metals," Pollution and Physiology of Marine Crganisms, F.J. Vernberg and W.B. Vernberg, (eds.). Academic Press, New York, pp. 123-135 (1974).

Bryan, G. H.. "Heavy Metal Contamiration in the Sea," In: Garine Pollution, R. Johnson, (ed.), Academic Press, New York, 185 pp. (1976).

Bryan, G.H.. "Some Aspects of Heavy Metal rolerance in Aquatic organisms," A.P.M. Lockwood, (ed.); Cambridge University Press, N.Y., 35 pp. (1977) .

Bryan, G.W. and L.G. Humerstone, "Adaptation of the Polychaete Nereis diversicololor to Estuarine sediments Containing High Concentrations of Heavy Metals I. General observations and Adaptation to Copper," Journal of the Marine Biological Association of the United Kingdom, 51(4):845-863 (1971).

Bryar, G.W. and L.G. Hummerstone, "Adaptatior of the Polychaete

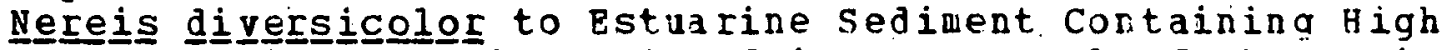
Concentrations of zinc and Cadmium." Journal of the Marine Biological Association of the United Kingdom, 53(4):839-857 (1973). 
Bucke, D., "Neoplasia in Roach (Eutilius rutitilus L.) from a Polluted Environment," Proqress in Experimental Tumor Research, $20: 205(1976)$.

Buikema, A.L., "Effects of Pollution on Freshwater Invertebrates," Journal of the water Pollution Control Federation, 49(6):1493-1506 (June 1977).

Euikema, A.I., Jr., J. Cairns; Jr., and G. T. Sullivan,

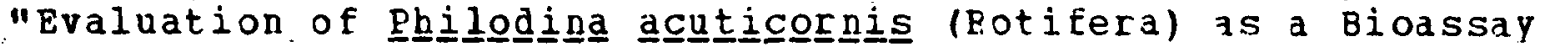
organism for Heavy Metals." Water Resources Bulletin, $10(4): 648-661(1974)$ :

Buikema, A.L., Jr., D.R. Lee, and J. Cairns, Jr., "A Screening Bioassay Using Daphnnia pulex for Refinery Wastas oischarged into Freshwater," Journal of Testing and Evaluaticn, 4 (2):119-125 (1976).

Buikema, A.L., Jr., et al., "Rotifers as Monitors of Heary Metal pollution in Water," Virainia Polytechnic Institute and state University, Water Resources Research Center Pulletin, 71:1 (1974).

Bulthuis, D., et al.. "Metal Dynamics in Municipal Stabilization ponds," Proceedirigs of the 7 th annual conference on Trace Substances in Environmental Health, D.D. Hemphill, (ej.). University of Missouri, Columbia (June 12-14, 1973).

Bumbu, Y.V. and A.S. Mokryak, "Effect of Some Trace Elements on the Development of the Algae scenedesmus euadrica Akademii Nauk. Moldavskoi SSR, Seriya Biologicheskikh i

Khimicheskikh Nauk (USSR), 1 (1973).

Rutler, R.L., et al.," "Fish and Food organisms in Acid Mine Waters of Pennsylvania," U.S. Environmental protection Agency Feport EPA-E3-73-032, 158 Pp. (1973).

Button, D.K. and S.S. Dunker, "Biological Effects of Copper and Arsenic Pollution," University of Alaska, Fairbanks, Institute of Marine Science Report R71-8, 59 Pp. (April 1971). (NTIS PB-201 6481

Cairns, J., Jr., "Effects of Increased Temperatures Upon Aquatic Organisms," Enginfering Bulletin of Purdue University, $40(1): 346$ $(1956)$.

Cairns, J., Jr. and K.L. Dickson, "Reduction and Restoration of the Number of Freshwater Protozoan species Following acute Exposure to Copper and Zinc," Transactions of the Kansas Academy of Science, 73:1-10 (1970). 
Cairns, J.. Jr. and A. Scheier, "Effects of Periodic Low Oxyyen Upon the Toxicity of Various Chemicals to Aguatic organisms." Proceedings of the $12 \mathrm{th}$ Industrial waste conference, Purdue Oniversity Engineering Extension Series, 94:165-176 (1958a).

Cairns, J.. Jr. and A. Scheier, "Relationship of Bluegill Sunfish Body size to Tolerance for some common Chemicals," Industrial Hastes, $3(5): 126$ (1958).

Cairns; J., JI. and A. Scheier, "The Effects of Temperature and Hardness of Water opon the Toxicity of zinc to the pond Snail,

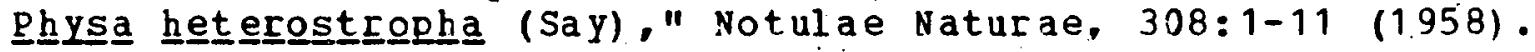

Cairns, J.. Jr. and A. Scheier, "A Comparison of the Toxicity of Some common Industrial waste comporents Tested Individually and Combined," Progressive Fish-Culturist, 30 (1):3-8 (1968)。

Calabrese, A. and D.A. Nelson. "Inbibition of Embryonic

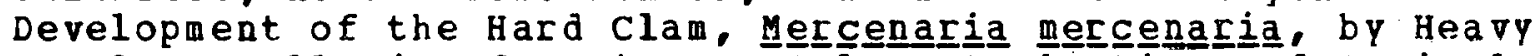
Metals." Bulletin of Environmental Contamination and Toxicology. 11:92-98 (197.3).

Calabrese, A., et al.. "Toxicity of Heavy Metals to Embryos of

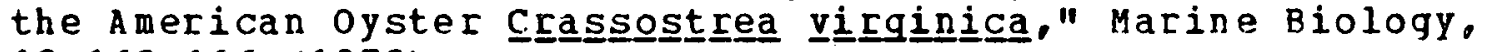
$18: 162-166$ (1973).

Calabrese, A., et al " "Effects of Cadmium, Mercury and Silver on Marine Animals," Marine Fisheries Review, 39:5 (1977).

Calabrese, A.. et al., "Survival.and Growth of Bivalve Larvae under Heavy-Metal Stress," Marine Biology, 41:179-184 (1977).

Calamari, D. and $R$. Marchetti, "Toxicity of Mixtures of Metals

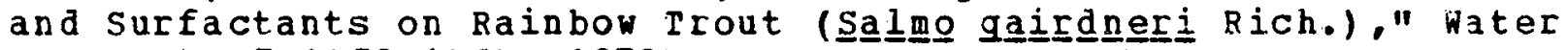
Research, 7:1453-1464 (1973).

Calamari, D. and $F$. Marchetti, "predicted and observed Acute

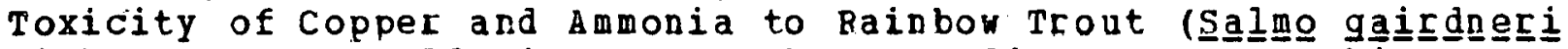
Rich.)," Water Pollution Research Proceedings, S.H. Jenkins, (ed.). Pergamon. New York, pp. 569-576 (1975); Progress in Water Technology, $7(3 / 4): 569-577$ (1975).

Campbell, R.S., et al., "Water Pollution Studies in Acid Strip-Mine. Iakes: Chanqes in Hater Quality and Community structure Associated with Aging." Proceedings of the 1st Symposium on Mire Drainage Research, Cincinnati: Ohio River valley water Sanitation Commission, pp. 188-198 (1965).

Cardwell, R.D., et al.. "Acute Toxicity of Selected Toxicants to Six species of Fish," U.S. Environmental protection Agency. Ecological Research Series Report EPA-600/3-76/008, 117 pP. (1976). 
Carpenter, K.E., "On the Rioloaical Factors Involved in the Destruction of Biver-Fisheries by Pollution Due to Lead "ining," Annals of Applied Biology, 12:1-13 (1925).

Carpenter, K.E.. "Lethal Action of Soluble Metallic salts on Fishes," British Journal of Experimental Bioloqy. 44:378-390 (1927).

Carpenter, K.E., "Further Research on the Action of Metallic Salts on Fishes," Journal of Experimental Zoology, 56:407-422. $(1930)$.

Carriker, N.E., W.T. Gillespie, and P,I, Brezonick, "Boron and Arsenic Studies in Florida Haters," Uniyersity of Florida Nater Resources Research Center, Gainesville, Rublication No. 34, 100 pp. (1976).

Carson, W.G. and W.v. Carson, "Toxicity of Copper and zinc to Juvenile Salmon in the presence of Humic Acid and Lignosulfates;" Fisheries Research Board of Canada uS Report No. 1181, 5 pp. $(1972)$.

Carter, J.W. and I.I. Cameron, "Toxicity Bioassay of Heavy latals in water Usirg Tetrahymena pyriformis." Nater pesearch, $7(7): 951-961(1 \mathrm{c73})$.

Cearley, J.E.. "Toxicity and Bioconcentrations of Cadmium, Chromium and Silver in Micropterus salmoides and Leponis nacrogchicus," Ph.D. thesis, University of Oklahoma, Norman, 76 pp. (1971).

Chapman, G., "Effect of Heavy Metals on Pish," oregon State University water kesources Research Report No. SFMN-WR-D16.73, pp. 141-162 (Jan. 1973).

Chen, C.W. and R.E. Silleck, "A Kinetic Model of Fish Toxicity Threshold," Journal of the Hater pollution Control Federation (Research supplement), 41 (8):R294-R308 (1969).

Cheremisinoff, P. and Y. Habib, "Cadmium, Chromium, Lead, and Mercury - Plenary Account for water Pollution I. Occurrence, Toxicity, and Detection," Water and Sewage Works, 119:73 (1972).

Christensen, G.M.. "Effects of Metal Cations and other chemisals Upon the in vitro Activity of Two Enzymes in the Blood plasma of the white Sucker, Catostormera commersoni (Lacepede)." Chemical-Biological Interactions, 4:351-361 (1971).

Christensen, G.M., "Biochemical Effects of Methylmercuric Chloride, Cadmium Chloride and Lead Nitrate on Embryos and Alevins of the Brook Trout, salvelinnus fontinaliss," Toxicology and Applied Pharmacology, 32:101 (1975). 
Clarke, R. MCV.. "The Fffects of Effluents from Metal Mines on Aquatic Ecosystems in Canada," B Iiterature Review, Department of the Environment. Resource Management Branch, Fish and Marine Service Research and Development Directorate, Technical Report No. 488, Minnipeg, Manitoba, 150 pp. (1974).

clarke, R. McV.. "A Sumary of Toxicity Information for Major Effluent components from Inorganic Chemical Industries." Department of the Environment. Fisheries and Marine servica Technical Report series No. CEN/T-74-9, Winnipeg, Manitoba $(1974)$.

Cleland, K.H., "Heary Metals, Fertilization, and Clearage in the Eggs of psammechinus miliaris," Experimental Cellular Research, $4(1): 246-248(1953)$.

Cole, A.E., "Effects of Pollutional wastes on Fish life," symposium on Hyarobiology. University of tisconsin, Madison, p. 241 (1941).

Coleman, R.D.. R.L. Coleman, and E.L. Rice, "zinc a ná Cobalt Bioconcentration and Toxicity in selected Algal Species," Botanical Gazette, 132:102-109 (1971).

Colmer, A.R. and M.E. Hinkle, "Acid Mine-Drainage Role of Microorganisms," Science. 106:253 (1947).

Conner, P.M. "Acute Toxicity of Heary Metals to some Marine Larvae," Marine Pollution Bulletin, 3(12):190-193 (1972).

Cook, R.H. and R.P. Cote, "Influence of Humic Acids on Toxicity of Copper and zinc to Juvenile Atlantic Salmon as Derived from the Toxic Unit Concept," Canadian Environmental protection Service, SS Feport No. 72-2, 27 pp. (1972).

Cook, R.H. and R.A.W. Hoos, "Base Metal Mine hater Pollution on the Nipisiguit River, New Brunswick," Canadian Research and Development Branch, MS Report 71-2, 27 pp. (1971).

Cook, R.H., R.A.W. Hoos, and R.P. Cote, "Toxicity of Copper and Zinc to Atlantic Salmon: Laboratory and Field Evaluations ith special Emphasis on High Hater Hardness Concentrations," Canadan Research and Development Branch, SS Report 71-16, 88 pp. (1971).

Cooke. H. B.. "our Mouldy Earth. A study in the Fungi of our Enviconment with Emphasis on Nater." Robert A. Taft Water Research Center Advanced waste Treatment Research Laboratory, cincinnati. Ohio (1970). (NTIS PB-217 074)

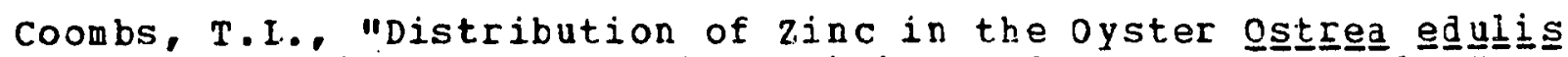
and Its Relation to Enzymatic Activity and to Other Metals," Marine Biology, 12:170-178 (1972). 
Cooper. E.L. and C.C. Wagner, "Effects of Acid Mine Drainage on Fish Population," Fish and Food organisms in Acid Mine Vaters of Pennsylvania, U.S. Environmental protection Agency Report EPA-R 3-73-032, pP. 73-124 (1973).

Corner, P.D.S. and B.H. Sparcow, "Modes of Action of Toxic Agents I. Observation of the Poisoning of Certain Crustaceans by Copper and Mercury." Journal of the Marine Biological Association of the Onited Kingdom, 35:531-548 (1956).

Costa, H.H.." "Response of Gammangus pulex (L.) to Modified Environment I. Reaction to Toxic solutions," Crustaceans, 11:245-256 (1966).

Cote, R.P.." Hardness as a Modifying Factor in Heavy Metal Toxicity." Canadian Research and DEvelopment Eranch, MS Report $71-18,23 \mathrm{pp} .(1971)$.

Coughtrey, P.J. and M.H. Martin, "The Uptake of Lead, Zinc, Cadmium, and Copper by the Pulmonate Mollusc, Helixx a Huller, and Its Relevance to the Monitoring of Heavy Metal contamination of the Environment," Oecologia, 27:65-74 (1977).

Cowell, B.C., "The Effects of sodium Arsenite and silvex on the Plankton Populations in Farm Ponds," Transactions of tbe American Fisheries Society. 94(4):371-377 (1965).

Craig. S., "Toxic Ions in Bivalves," Journal of the American Osteopathic Association, 66:1000-1002 (1972).

Crandall, C.A. and C.J. Goodnight, "The Effects of sublethal Concentrations of Several Toxicants to the Common Guppy, Lẹbistẹs reteticulatus. " Transactions of the American Microscopical Society. $82: 59-73(1963)$.

Cross, F.A. and J.H. Brooks, "Concentrations of Manganese, Iron, and Zinc in Juveniles of Five Estuarine-Dependent Fishes," Radionuclides in Ecosystems, Vol. 2, D.J. Nelson, (ed.), Proceedings of the 3rd National Symposium on Radioecoloqy, Oak Ridge, Tenn.. pp. 769-775 (May 10-12, 1971) . (Available from NTIS)

Czapowskyj, M.M.. "Arnotated Bibliography on the Ecology and. Reclamation of Drastically Disturbed Areas," U.S. Departinent of Agriculture Forest Service General Technical Report. NE-21, NE Forest Experiment Station, Upper Darby, 2enr., 98 pp. (1976).

D'Agostino, A. ard C. Finney, "The Effect of Copper and Cadmium on the Development of Tigriogous japponicus." In: pollution and Physiology of Marine organisms, F.J. Vernberg and (eds.). Academic Press, New York, pp. 445-454 (1974). 
D'Amelio, v., et al., "Effect of Heavy Metals on protein Synthesis in crustaceans and Fish," Revue Internationale d'oceanographie Medicale, 33:111 (1974).

Dahl. J.. "Transformation of Iron and Sulfur Compounds in soil, and Its Relation to Danish Inland Fisheries," Transactions of the American Pisheries Society, 92:260-264 (1963).

Dams, R., et al., "Symposium on Trace contaminants in the Environment," American Institute of Chemical Engineers, New York $(1975)$.

Davies, P.H., "Need to Establish Heavy Metal standards on the Basis of Dissolved Metals," Proceedinas of the International Joint Commission's Workshop on Toxicity to Biota of Metal Forms in Natural water, October 7-8, 1975, Duluth, Minn. (April 1976).

Davies, F.H. and J.P. Goettl, Jr., "Aquatic Life - water Quality Recommendations for Heavy Metal and other Inorganic Toxicants in rresh water," Report for the water quality standards Revision committee and the Colorado water Quality. Control Commision (July, 1976).

Decker, C. and F. Menendez, "ACute Toxicity of Iron and Aluminum to Brook Trout," proceedings of the West virginia Academy of science, 46:159 (1974).

Decker, C.F., C.A. Hoppert, and R.U. Byerrum, "Report on Toxicity Studies of Cadmium and Chromium," Journal of the American Water Works Association, 48:1279 (1956).

De L.G. Solbe, J.F., "Relation Between water quality and the status of Fish Populations in Willow Brook," Water Treatment ad Exanination, $22(1): 41-61$ (1973).

De L.G. Solbe, J.F., "The Toxicity of Zinc sulphate to Rainbow Trout in Very Hard Water," Water Research, 8(6):389-391 (1974).

De. I.G. Solbe, J.F. and V.A. Cooper, "Studies on Toxicity of

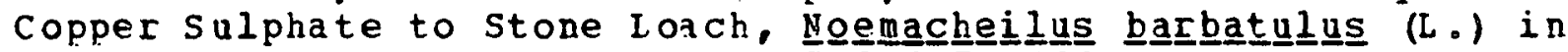
Hard Water," Water Fesearch, 10:523-527 (1976).

De L.G. Solbe, J.F. and V.A. Flook, "Studies on the Toxicity of Zinc sulphate and of Cadmiun Sulphate to stone Ioach Noengachẹe barbatulus (L.) in Hard Hater," Journal of Pish Biology. $7(4): 631-637$ (1975).

Dettman, E.H. and R.D. Olsen, "Assessment of water Quality Impacts of a western Coal Mine," In: The Reclamation of Disturbed Arid Lands, R.A. Wright, (ed.), University of New Mexico Press, Al buquerque, pp. 53-67 (1978). 
Dhar, S.K., (ed.), "Metal Ions in Biological Systems," Advanaes in Experimental Medicine and Biology, Vol. 40, Plenum, New York $(1973)$.

Dieh1. W. T., "A Comparative Study of Plankton Respiration in an Acid Polluted Lake and Acid Free Embayments," Proceedings of the West Virginia Academy of Science, Biolcgy Section, 44(1):24-32 (1972).

Dietz, F." "The Enrichment of Heavy Metals in Suhmerged plants," Advances in Hater Pollution Research," Proceedinqs of the 6th International Conference on. Water Pollution Research, Pergamon, London (1972).

Dilling, W.J. and C.W. Healey, "Irfluerce of lead and the Metallic Ions of Copper, Zinc, Thorium, Beryllium, and Thallium on the Germination of Frogs' Spawn and on the Growth of Tadpoles," Annals of Applied Biology, 13(2):177-188 (1926); Biological abstracts, 2:3485 (1928).

Doudoroff, P.. "Some Recent Developments in the study of Toxic Industrial wastes." Proceedings of the 4 tb annul Pacific Northwest Industrial Waste Conference, Pullman, Hash. (1952).

Doudoroff, R., "Water Quality Requirements of Fishes and Effects of Toxic Substances," The Physiology of Fishes, Vol. 2, M.E. Brown. (ed.). Academic Press, New York, pp.403-430 (1957).

Doudoroff, P. and M. Katz, "Critical Review of Literature on the Toxicity of Industrial wastes and.Their Components to Fish II. The Metals, as Salts," Serage and Industrial Wastes, $25(7): 802-839$ (1953).

Doudoroff, P.. G. Luduc, and C.R. Schneider, "Acute Toxicity to Fish of Solutions Containing Complex Metal Cyanides, in Relation to Concentrations of Molecular Hydrocyanic Acid," Transactions of the merican Fisheries Society, $95(1): 6-22$ (1966).

Dowden, B.F. and H.T. Bennett, "Toxicity of selected Chemicals to Certain Animals." Journal of the Hater Pollution Contrpl Federation, $37(9): 1308-1316$ (1965).

Doun, C.G. and J. Stocks, "Environmental Impact of Mining," wiley, New York, $371 \mathrm{pp}$. (1977).

Drucker, H. and R.E. Wildung, (eds.). "Biological Implications of Metals in the Environment." Energy Research and Development. Administration, Symposium Series No. 42, 1977, Oak Ridge, Tenn.. 682 PP. (1977). (NTIS CONF-750929/RAS)

Dulka, J.J. and T.H. Risby, "Ultratrace Matals in Some Environmental and Biological systems," Anzlytical Chemistry, 48:642-653 (1976). 
Dvorak. A.J.. et al.. "Environmental Effects of using Coal for Generating Electricity." Argonne National Laboratory Report NOEEG-0252 (1977).

Eaton, J.G., "Chronic Toxicity of a Copper, Cadmium and Zinc Mixture to the Fathead Minnow (piquephales promelas Bafinesque)." Nater Res earch, $7(11): 1723-1736$ (1973).

Eaton. J.G.." Testimony in the Matter of Proposed Toxic Pollutant Effluent standards for Aldrin-Dieldrin, et al. ". Federal Hater Pollution Control Administration (307) Docket No. 1 (1974).

Ebeling. G.. "Toxicity of some Heavy Metal Salts," Abwasser, 26:95 (1928).

Ebeling, G.. "Toxicity of Heavy Metals to Rainbow Trout," Journal of the American Water horks Association, 23: 1626 (1931).

Edminster, J.O. and J.W. Gray, "Toxicity Threshold for Three Chlorides and Three Acids to the Fry of the hitefish (Coregonus

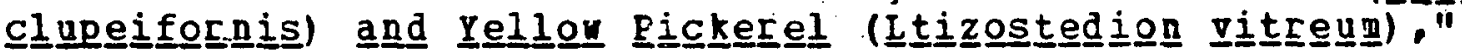

Progressive Fisb-culturist, $10: 105-106$ (1948).

Eisler, R.. "Annotated Bibliography on Biological Effects of Metals in Aquatic Environments," U.S. Environmental protection Agency, Ecological Research Series EPA-R3-73-007, 287 pP. $(1973)$.

Eisler, R.. "Acute Toxicities of selected Heary Metals to the Softshell Clam, 포a a Contamination and Toxicolog $, 1.7: 137$ (1977).

Eisler, R. and G.R. Gardner, "Acute Toxicology to an Estuarine Teleost of lixtures of Cadmium, Copper, and $\mathrm{Z}$ inc Salts," Journal of Fish Biology, 5:131-142. (1973) .

Eisler, R. and R.J. Hennekey, "Acute Toxicities of Cd2t, Crft. Hg2t, Ni2+ and 2n2+ to Estuarine Macrofauna," Archives of Environmental Contamination and Toxicology, $6: 315-323$ (1977).

Fisler, R. and M. Wapper, "Second Annotated Bibliography on Biological Bffects of Metals in Aquatic Environments," U.S. Environmental Protection Agency Report BPA-500/3-75.008 (1975).

Elwood, J.W. and L.D. Eyman, "Test of a Model for Predicting the Body Burden of Trace contaminants in Aguatic Consumers, Journal of the Fisheries Research Board of Canada, 33:1162 (1976).

Elwood, J.W., S.G. Hildebrand, and J.J. Beauchamp, "Contribution of Gut contents to the concentration and Body Burden of elements in ípula spp. from a spring-fed stream," Journal of the Fisheries Research Board of Canada, $33(9): 1930-1938$ (1976). 
Fmerson, K., et a1.. "Aqueous Ammonia Equilihrium Calculations: Effect of $\mathrm{pH}$ and Temperature," Journal of the Pisheries Research Board of Canada, 32 (12):2379-2383 (1975) .

Enk, M.D. and B.J. Gathis, "Distribution of Cadmium and Lead in a stream Ecosystem," Hyarobiologia, 52:153 (1977).

Erichsen, I.V. and K. Kaemmerer, "Effect of line vaste vaters Containing Metal Salts on the Eiological Conditions in a River System," Water Pollution Abstracts, 25 (4):95 (1952).

Establier, R. and E. Pascual, "Studies on Copper, Iron, Manganese, and Zinc in oysters (SEassostrea angulatalu) on the Gulf of Cadiz." Investigacion Pesquera, 38(2):371-384 (Apri1 1974).

Falk, M.R., M.D. Miller, and S.J.H. Kostiuk, "Biological Effects of Mining Nastes in the Northwest Territories," Department of the Environment. Fisheries and Marine Service, Technical Report Series No. CEN/T-73-10, Winnipeg, Manitoba (1973).

Federation of Sewage and Industrial pastes associations, "Toxicity of Mercuric Chloride, Chromic sulfate, and Sodium Chromate in the Dilution B.O.D. Test," Sewage and Industrial Wastes, $26(4)=536-538$ (1954).

Federation of Sewage and Industrial Hastes associations, "Toxicity of Copper and $z$ inc Ions in the Dilution 900 Test," Sewage and Industrial Hastes, $28(9): 1168-1169$ (1956).

Fedkenheuer, P.J., (ed.). "Impact of Lead Mine and Mill Effluent on Aquatic Iife," $47 t h$ Annual Metting and 35 th Annual Mining Symposium, American Institute of Mining, Metallurgical, and Petroleum Engineers, aneral Resources Research.Center, Minneapolis, 150 pp. (1974).

Fitzqerald, G.P.. "Are Chemicals osed in Alqae Control Biodeqradable?," Water and Sewage Horks, 122(5):82-85 (1975).

Fogels, A. and J.B. Sprague, "Comparative Short-Term Tolerance of zebrafish, Flagfish, and Rainbow Trout to Five poisons Including Potential Reference Toxicants," Water Research, 11:811 (1977).

Food and Agriculture organization, "Inventory of Data on Contaminants in Aguatic organisms," FAO Fisheries Circular No. 338. Department of Fisheries, Fome (1976).

Foster, P.. "Concentrations and concentration Pactors of Heavy. Metals in Brown Algae." Environmental Pollution. 13:45-53 (1976).

Fowler, D.B.. "Fecundity of the Brown Bullhead. Ictaㅡ므므ㄴㅡㅗ nebulosus (Le Suer), in a Mine Acid Polluted River," Thesis, West Virginia University, Morgantown (1975). 
Frahm, J.P., "Toxicity Tolerance studies Mtilizing periphyton (Toxitoleranzversuche an wassermoosen)," Gewasser und Abrassor, 57/58:59-66 (1975).

Frazier, J.H., "Current Status of knowledge of Biological Effects of Heavy letals in the chesapeake Bay," army Corps of Engineers, Chesapeake Bay Existing Conditions Report, Appendix C, Vol. 2 , pp. C193-C201 (1973).

Frazier, J.M.. "The Dynamics of Metals in the American Oyster,

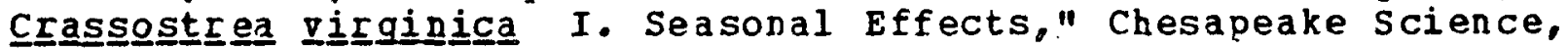
$16(3): 162-171 \cdot(1975)$.

Frazier, J.M., "The Dynamics of Metals in the American Oyster,

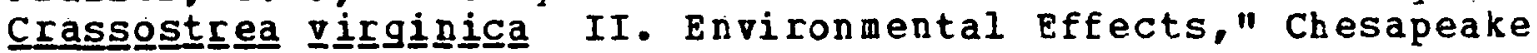
Science, $17(\overline{3}): 188-197$ (1976).

Fromm, P.0.. "Toxic Action of Nater Soluble pollutants on Freshwater Fish," EPA Nater Pollution Control Research Series No. 18050DST, O.S. Government Printing office, washington, D.C. (1970): Michigan State University Water Pollution Control Research Series, East Lansing (1970). (NTIS PB-201 650)

Funk, H.H.. "Biological Impact of Combined letallic and Organic Pollution in the Coeur D'Alene-Spokane River Drainage System," Mashington state oniversity and oniversity of Idaho keport to. OWRR, B- 0.44 wash and B-015 IDA (1973).

Gaechter, R. " Heavy Metal Toxicity ard Synergism to Natural phytoplankton in the Eutrophic Lake alpnach and the Mesotrophic Horw. Bay," Schweizerische Zeitschrift. fur Hydrologie, 38(2):97 (1976).

Gale, N.I., P. Marcellus, and G. Underwood, "Life, Iiberty, and the Pursuit of Lead: The Inpact of Lead Mining and Milling Activities on Aquatic organisms," Trace contaminants in the Environment, Proceedings of the 2 nd annual NSF-FANN Trace Contaminants conference, Asilomar, Pacific Grove, Calif. (Aug. 29-31. 1974).

Gale, N.L., et al.. "Aguatic Organisms and Heavy Metals in Missouri's Neu lead Belt," Bulletin of American water Resources Association, 9:673-689 (1.973).

Gale, N.L.. et al.. "Transport of Trace Pollutants in Lead Mining waste waters," Trace Substances in Environmental Health IV. P. 95 (1973).

Gale, N.L.., et al.." The Impact of Lead Mine and Mill Effluents on Aquatic Life," presented at tbe Environmental Session of the Mining Symposium, Oniversity of Minnesota. Minneapolis (Jan. 1974). 
Gale, N.L.. et a 1.. "Impact of Lead Mine Effluents on Aquatis Life," Proceedings of the 35 th Annual Mining symposium, P.J. Fedkenheuer, (ed.), American Institute of Mining, Metaliurqizal, and Petroleum Engineers, Duluth, Minn. (1974).

Ganther. H.E.. et al.. "Protective Effects of Selenium against Heavy Metal Toxicities," Trace Substances in Environmental Health, Vol. VI, D.D. Hemphill, (ed.), Oniversity of Missouri, Columbia, pp. 247-252 (1972).

Ganther, H.E. et al., "Selenium: Relation to Decreased Toxicity of Methylmercury Added to Diets Containing Tuna," Science, 175: $1122(1972)$.

Gardner, G.R. "Chemically Induced Lesions in Estuarine or Marine Taleosts," Pathology of Fishes, H. E. Pibelin and G. Migaki. (eds.). University of Hisconsin Press, Madison, pp. 657-693 (1975).

Garton, R.R.p "Biological Effects of Cooling Tower Blowdown," Presented at the $71 \mathrm{st}$ annual Meeting of the American Institute for Chenical Enqineers, Dallas, 25 pp. (1972).

Gasper. D.C." "Harmful Impacts of Current surface Mine Reclamation on Infertile Trout Streams and Their Future." Northeast Fish and Hildife Conference, Hershey, Penn. (1976).

Geldiay, R, and H. Uysal, "Comparative Behaviour of Toxic Metals in a Marine Fcosystem," In: Origin and Fate of Chemical Residues in Food, agriculture and Fisheries, proceedings and Report of Two Research Coordination Meetings organized by the Joint FAo/ IAEC Division of Atomic Energy in Food and Agriculture, Vienna, International Atomic Energy Agency, Pp. 69-76 (1975).

Giesy, J.P., Jr. and J.G. Hiener, "Frequency Distribution of Trace Metal concentrations in Five Freshwater Fishes,"

Transactions of the American Fisheries Society, 106(4):393-403 $(1977)$.

Gillette, L.A., D.L. Miller, and H.E. Redman, "Appraisal of a Chemical Waste Problem by Fish Toxicity Test," Sewage and Industrial Wastes, $24(11): 1397-1401$ (1952).

Gleason, V.E. and H.H. Russell, "Coal and the Environment Abstract Series: Mine Drainage Bibliography $1910-1976$," Bituminous Coal Research, Inc., Monroeville, Penn., 288 pp. $(1976)$.

Glenn-Lewin, D.C.. et al., "Bibliography of Strip Mine Ecology," Jowa State University, Energy and Mineral Resources Research Institute Report No. IS-ICP-20 (1970). 
Gooding, D.o "Pollution Research Toxicity Studies," Hashington State Department of Fisheries, 64th hnnul Report, olympia $(1954)$.

Gough, I.P. and H.T. Shacklete, "Toxicity of selected Elements on Plants, Aimals, and Man-an Outline," Geochemical survey Open File Report No. 76-729, Appendix IV (1976).

Grande. H. "Effect of Copper and Zinc on Salmonid Fishes," Advances in rater Pollution Research, Vol. I, proceedings of the 3ra International conference, Nater pollution Control Federation, Washington. D.C., Pp. 97-111 (1967).

Gray. JoS. "Synergistic Effects of Three Heavy Metals on Growth Rates of a Marine Ciliate protozoan," Pollution and Physiology of Marine organisas, F.J. Vernberg and H.B. Vernbera, (eds.). Academic Press, New York, pp. 465-485 (1974).

Gray, J.S. and J.J. Ventilla, "Growth Rates of Sediment-Living Marine Protozoan as a Toxicity Indicator for Heavy Metals" A w bio. $11(4): 118-121$ (1973).

Great Lakes Laboratory, "Chromium, Cadmium, Arsenic, Selenium, Hercury, and Aguatic Iife: A Brief literature Review," State Universit College at Buffalo, N.Y.. Special Report No. 9 (1971).

Greenshields, J.. "Algal Flora of Acid Mine Water Impoundments in Tuscarawas county. Ohio with Special Feference to the Bacillariophyta," ".S. thesis, Kent state University, Kent, Jhio, 120 pp. (1973).

Greichus, I.A., et al.. "Insecticides, Polychorinated Biphenyls and Metals in African Lake Ecosystems. I. Hartbeespoort Dam, Transval, and Voelvlei Dam, Cape Province, Republic of South Africa," Archives of Environmental Contamination and Toxicology, $6: 371-383(1977)$.

Grindley, J., "Toxicity to Rainbow Trout and innows of some Substances known to be Present in Waste Water Discharged to Rivers," Annals of Applied Biology, 33:103-112 (1946).

Guerra, M. and N. Comodo, "Evaluation of Tolerance limits of some Toxic Substances in Industrial waste waters by the Icthyo-Toxicity Test., "Bolletino della societa Italiano di Biologia Sperimental, $48(22): 989$ (1972).

Haberer, K. and S. Normann, "Trace Metals in (Surface) Haters," Von Nasser, 38:156-182 (1971).

Hahne, B.C. and K. KroontJe, "Significance of pH and Chloride Concentration on Behavior of Heavy Metal pollutants: Mercury (II). Caduiun (II), Zinc (II), and Lead (II)." Journal of Environmental Quality; 2:444-451 (1973). 
Hale, J.G.. "Toxicity of Metal Mining Hastes," Rulletin of Environmental Contamination and Toxicology, $17(1): 66-73$ (1977).

Hall. E.P., "Pollution from Mine-Drainage," Encyclopedia of Environmental Science and Engineerinq. Vol. 2, J.P. Pfafflin and E.N. Ziegler, (eds.). Gordon and Breach, New York, pp.694-699 $(1976)$.

Hannan, P.J. and C. Patouillet, "Effect of Mercury on Algal Growth Rates," Biotechnology and Bioengineering, 4:93-101 (1972).

Hara, T.J., et al.. "Effects of Mercury and Copper on olfactory Response in Rainbow Trout, Salmo gairdaneri." Journal of the Fisheries Research Board of Canada, 33:1568 (1976).

Hardisty. M. H.. et al.. "Ecological Implications of Heavy Metal in Fish from the Severn Estuary." Marine pollution Bulletin. 5: $12-15$ (1974).

Hargreaves, J.W. and B.A. Whittor, "Effect of pH on Tolerance of

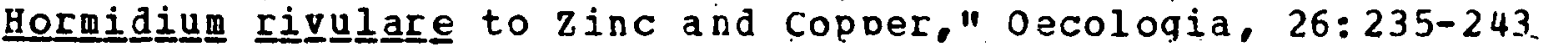
$(1976)$.

Harp, G.I. and B.S. Campbell, "The Distribution of rendipes plumosus (Linne,) in Mineral Acid water," Limnology and oceanography, 12:260-263 (1967).

Harrison, A.D., "Some Environmental Effects of Coal and Gold Mining on the Aquatic Biota," Biological Problems in Mater Pollution, C.M. Tarzwell, (ed.), 0.S. Public Health Service Publication No. 999-WP-13, pp. 270-274 (1962).

Farrison, E.A., (ed.), "Bioindicators of Pollution (A Bibliography with abstracts)," Covering 1964-1976 (Oct: 19761. (NTIS PS-76/0868)

Hart, C.H., Jr, and S.L.H. Fuller, (eds.), "Pollution Ecology of Freshwater Invertebrates," Academic Press. New York, 389 pp. (1974).

Harvey, R.S. and R. Patrick, "Concentration of $137 \mathrm{Cs}, 65 \mathrm{z}$, and $85 \mathrm{Sr}$ by Freshwater Algae," Biotechnology and Bioengineering. $9: 449-456(1967)$.

Hawley, J.R., "The Ise, Characteristics and Toxicity of Mine-Mill Reagents in the Province of Ontario," Ministry of the Environment, $135 \mathrm{st}$. Clair 4ve.. W. Toronto, Ontario, (1972).

Heit, M., "A Review of Current Information on some Ecological and Health Related Aspects of the Felease of Trace Metals into the Environment associated with the combustion of coal, "Health and Safety Laboratory. Energy Research and Development Administration Technical Information Center No. HASL-320 (1977). 
Hellman, H., "Adsorption of Heavy Metals by Suspended Solids in Rhine River. Examination Pertaining to Rhine water Contamination," Deutsche Gewasserkundliche Mitteilungen. 14:42 $(1970)$.

Helz, G.R., R.J. Huggett, and J.H. Hill, "Behavior of Mn, Fe, Cu, $\mathrm{Zn}$. $C \mathrm{~d}$, and $\mathrm{Pb}$ Discharged from a Nastewater Treatment plant into an Estuarine Environment," "rater Research, 9:631-636 (1975).

Hem, J.D. "Chemical Pactors that Influence the Availability of Iron and Manganese in Aqueous systems," Geological society of Anerica Bulletin, 83:443-450 (1972).

Hemphill, D.D., (ed.). Proceedings of the 5tb annual conference on Trace Substances in Environmental Health, June 29-July 1, 1971. University of Missouri, Columbia (1972).

Henly, J.P.. "Stream Botton Fauna: Influences of Strip Mining on the Hydrologic Environment of Parts of Beaver Creek Basin. Ky.. 1955-1966." O.S. Geological survey Professional Paper No. 427-C, pp. C46-C49(1970).

Herbert, D.W.M., "The Toxicity to Rainbow Trout of Spent Still Liquors $f r o m$ the Distillation of Coal," Annals of Applied Biology, $50(4): 755-777$ (1962); Biological Abstracts; $42: 20607$ (1963).

Herbert, D.W.M. and D.S. Shurben, "The Toxicity to Pish of Mixtures of Poisons $I$. Salts of Ammonia and Zinc," Annals of Applied Biology, 53:33-41 (1964).

Herbert, D.H.M. and J.M. VanDyke, "The Toxicity to Fish of Mixtures of Poisons II. Copper-Ammonia and Zinc-Phenol Mixtures," Annals of Applied Biology, 53:415-421 (1964).

Hermann, E.R., "A Toxicity Index for Industrial Hastes," Industrial and Engineering Chemistry, 51:84A-87A (1959).

Herricks, E.E., "Becovery of Stream Macrobenthic Commuities from tbe Effects of Acid Mine-Drainage," Presented at the 4 th symposium on Coal uine-Drainage Research, Pittsburgh, pp. $370-398(1972)$.

Herricks, E.E.. "Becovery of Streams from Chronic Pollutional Stress - Acid Mine-Drainage," Recovery and Restoration of Damaged Ecosystems, J. Cairns, Jr., K. L. Dickson, and E.E. Herricks, (eds.). Oniversity Press of Virginia, Charlottesville, (AQ H540 I71 E) (1977).

Herricks, E.E. and V.O. Shanholtz, "Predictinq the Environmental Impact of Mine Drainage on Stream Biology," Transactions of the American Society of Aqricultural Fngineers, 19(2):271-283 (1976). 
Hildebrand, S.G., R.M. Cushman, and J.A. Carter, "The potential Toxicity and Bioaccumulation in Aquatic Systems of Trace Elements Present in Aqueous Coal Conversion effluents," In: Trace Substances in Environmental health - X. D.D. Hemphill, (ed.), University of Missouri, Columbia, pp. 305-313 (Dec. 1976).

Hill, D.H.." "Stream Faunal Recovery After Manqanese Strip Mine Reclanation," Ph.D. thesis, University of Michigan, Ann Arbor (1972).

Hill, D. and R. Bates, "Acid Mine Drainage and Subsidence Health and Ecological Effects of Increased Coal Utilization," Resource Extraction and Handling Division. Industrial

Environmental Research Laboratory, U.S. Environmental protection Agency (Nov. 4, 1977).

Hill, R.A., "Hater Quality and Biotic Development in and Around Final-cut Reservoirs at the Peabody Coal Co. Will scarlet ine," Peabody Coal Co. Report, St. Louis, Mo., 12 pp. (1976).

Hiltibran, B.C.. "Effects of Cadmium, Zinc, Manganese, and Calcium on Oxygen and Phosphate Metabolis of Bluegill Liver Mitochondria," Journal of the water Pollution Control Federation, $43(5): 818-823(1971)$.

Hoehn. R.C. and D.R. Sizemore, "Acid Mine Drainage (AMD) and Its Impact on a Small Virginia Stream," Water Resources Bulletin, $13(1): 153-160$ (1977).

Holland, G.D., et al., "Toxic Effects of Organic and Inorganic Pollutants on Young Salmon and Trout," Washington Department of Fisheries Research Bulletin, D.S., 5:265 (1960).

Hopkins, R. and J.H. Kain, "Effect of Marine Pollutants on

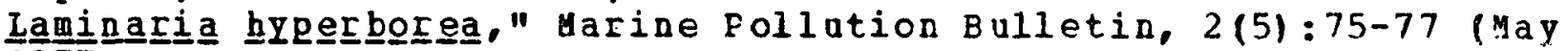
1977).

Howard, A.G.. "The Nature of Heary Metal Complexes in Molluscs," Ph.D. thesis, Oniversity of Bristol, O.K. (1975).

Hublou, W.F.. J.W. Hood, and E.R. Jeffries, "Toxicity of zinc or Cadmium for Chirook Salmon," oregon Fish Commission, Research Briefs, $5(1): 8-14(1954)$.

Huckabee, J.W. and B.G. Blaylock, "Transfer of Mercury and Cadmium from. Terrestrial to Aquatic Ecosystems," Metal Ions in Biological Systems, S.K. Dhar, (ed.), Plenum, New York, pp. $125-160$ (1973).

Huckabee, J.W. and N.A. Griffith, "Toxicity of Mercury and Selenium to the Eggs of Carp (CYprinus carpiol, "Transactions of the American Fisheries society, $103(4): 822-825$ (1974). 
Huckabee, J.W.. C.P. Goodyear, and R.D. Jones, "Acid Rock in the Great Smokies: Onanticipated Impact on Aquatic Biota of Road construction in Regions of Sulfide Mineralization." Transactions of the American Fisheries Society. 104 (4):677-684 (1975).

Hughes, J.S., "Toxicity of some Chemicals to striped Bass (Rogçus saxatilusl." Proceedings of the $22 \mathrm{nd}$ annual conference of the Southeastern Association of Game Fish Commerce, pp. 230-234 $(1969)$.

Hunter, W.R., "Poisoning of Harinogammarus marinus by Cupric Sulphate and vercuric chloride," Journal of Experimental Bioloqy, $26(2): 113-124$ (1949).

Hutchinson, T.C.. "Comparative studies of the Toxicity of Heavy Metals to Phytoplankton and Their synergistic Interactions," water Pollution Research in Canada, 8:68-90 (1973).

Hutchinson, T.C. and H. Czyrska, "Cadoium and zinc Toxicity and Synergisu to Floating Aquatic Plants," Nater Pollution Research in Canada. 7:59-65 (1972).

Hutchinson, T.C. and H. Czyrska, "Heavy Metal Toxicity and synergism to Floating Aquatic Needs," Verhandungen

Internationale Vereinigung fur Theoretische und angewunde Iimologie, 19:2102-2111 (1975).

Hutchinson, T.C., et al., (eds.), "International conference on Heavy.Metals in the Environment," Vol. II., Pathways and Cyclina, Institute of Environmental studies, Dniversity of Toronto, ontario (1977).

Inglis, A. and E.L. Davis. "Effects of Nater Hariness on the Toxicity of Several Organic and Inorganic Herbiciles to Pish," 0.S. Bureau of Sport Fisheries and Wildife Technical paper No. 67. pp. 1-22 (1972).

Ishio, S.. H. Nakagawa, and T. Tomiyama, "Algal Cancer and its Causes. II. Separation of Carcinogenic Compounds from sea Bottom Hud Polluted by wastes of the coal chemical Industry." Bulletin of the Japanese society of Scientific Fisheries, $38(6): 571-576$ (1972). (ORNIJ/tr-2848)

Iwao, T., "Comparative Investigations of the Toxicity of various Metals," Journal of the Nater Pollution Control Pederation, 32:67 $(1.960)$.

Jackim, E., "Influence of Lead and other Metals on Fish Delta-Aminolevulinate Dehydrase Activity," Journal of the Fisheries Research Board of Canada, 30(4):560-562 (1973). 
Jackim, E.. J.M. Hamlir, and S. Sonis, "Effects of Metal Poisoning for Five Liver Fnzymes in the Killifish (Funduuㅡ몽 heteroclittus)," Journal of the Fisheries Research Board of Canada, $27: 383-390$ (1970).

Jenkins, D.R.. "Flow of Toxic Metals in the Environment," International conference on Environmental sensing and assessment. vol. I, Las Vegas, Hev. (Sept. 14-19, 1975).

Jenne, E.A., "Controls on Mn, Fe, Co, $\mathrm{Ni}, \mathrm{Cu}$, and $\mathrm{Zn}$ concentrations in soils and water: The significant Role of Hydrous Mn and Fe Oxides," Advanced Chemistry. 73:337-387 (1968).

Jensen, F.A. and R.H. Hann, Jr., "The Intercelationship of Material Toxicity, Strean Properties and Quartity of spilled Material in assessing the Risk of Hazardous Material spills." Texas A $\mathbf{M}$ Oniversity Sea Grant Program Report, 75-212, 261 pp. (1976).

Johnson, M.G.. M.F.P. Michalski, and A.E. Christie, "grfects of Acid Mine Hastes on Phytoplankton Commities in Two Northern Ontario Lakes," Journal of the Fisheries Research Board of Canada, 27:425-444 (1970).

Jones, A.A. and D.V. Ellis, "Sub-obliterative Rffects of Mine-Tailings on Marine Infaunal Benthos (II). Effect on the Productivity of Ammotrypane aulogaster." Water, Air, and soil Pollution, 5(3): $299-307(1976)$.

Jones, J.R.E.. "Toxic Action of Heavy Metal salts on the

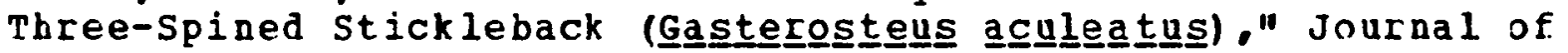
Experimental Biology, 12:165-173 (1935).

Jones, J.R.E.. "The Relative Toxicity of Salts of Lead, Zinc and Copper to the stickleback (Gasterostegus acculeagetus $\tau$. ) and the Effect of calcium on the Toxicity of lead and inc Salts," Journal of Experimental Biology, 15:394-407 (1938).

Jones, J.R.E.. "Antagonism Between Salts of the Heary and Alkaline-Earth Metals in Their Toxic Action on the radpole of the

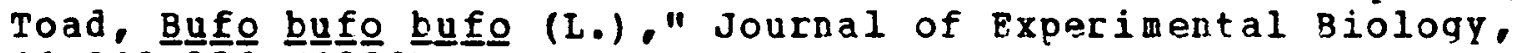
$16: 313-333(1939)$.

Jones, J.R.E., "The Relation Between the Electrolytic solution Pressures of the vetals and Their Toxicity to the stickleback (Gasterosteus açul $16: 425(1939)$.

Jones, J.R.E., "A Study of the Relative Toxicity of anions with Polyceli $\underline{\text { s }}$ nigra as a Test Animal," Journal of experimental Biology, 18:170-181 (1941).

Jones, J.R.E., "A Further study of the Reactions of Pish to roxic Solutions," Journal of Experimedtal Biology, 25:22-34 (1948). 
Jones, M.B.." "Synergistic Effects of Salinity, Temperature, and Heavy Metals on Mortality and osmoregulation in Marine and Estuarine Isopods (Crustacea)," Marine Biology, 30:13 (1975).

Joseph, J.M., "Microbiological Study of Acid Mine Naters: Preliminary Report," Ohio Journal of Science, 53:123 (1953).

Joseph, J.M. and D.E. ShaY, "Viability of Eschererichía coli in Acid uine Haters," American Journal of Public Health, $42: 795$ (1952).

Jude, D.J.. "Sublethal Effects of Ammonia and Cadmium on Growth of Green Sunfish," Onpublished Ph.D. thesis, Michigan State University, East Lansing, 193 pp. (1973).

Kalabina, N.M., et al.. "effects of the Toxic substances in Effluents from Non-Ferrous letal Industries on the Microorganisms and Biochemical processes associated with the self-purification of Hater in Storage Basins," Gigiena (USSR), 9(10): 1 (1944).

Karbe, L.. "Uarine Hydroids as Test organisms for Assessing the Toxicity of Mater Pollutants. Effects of Heavy Metals on

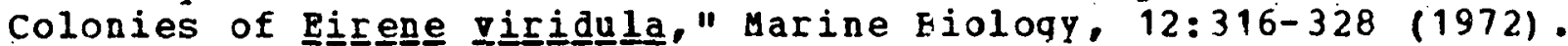

Karbe, L.. et al.. "Influence of Water Quality on Accumulation of Heavy Metals in Aquatic organisms, "Verhandlungen Internationale Vereinigung fur Theoretische und Angewandte Iimnologie, 19:2094 $(1975)$.

Kato, T., "Toxicity of Chemical substances (Heavy Metals, etc.) to Fish and Animals," Nagoya Shiritsu Daiqaku Igakkai Zasshi, $24: 11$ (1973).

Katz, M., "Biological and Ecological Effects of acid Mine Drainage with Particular Emphasis to the Waters of the Appalachian Begion," Impact of Mine Drainage on Recreation and Stream Ecology, Appendix F, Mashington, D.C., Appalachian Regional Commission (June 1969).

Katz, M.. "The Effects of Heavy Metals on Fish and Aquatic. Organisms," In: Heary Metals in the Aquatic Environment, proceedings of a symposium at vanderbilt oniversity. Dec. 4-7. 1973. Nashille, Tenn. (1973).

Kemp. H.T., et al.. "Water Quality Criteria Data Book - Vol. V: Effects of Chemicals on Aquatic Life," O.S. Environmental Protection Agency, Water Pollution Control Research Series Report 18050-HLA-09/73, 537 PP. (Sept. 1973). (NTIS PB-234 435) 
Kerfoot, M.B. and G.A. Kedmann, "Permissible Levels of Heavy Metals in Secondary Bffluent for Use in a Combined Sewage Treatment-Marine Agriculture System II. Development of Guidelines ry Method of Additions," Proceedings of the conference on Wastewater Use in the Production of Food and Fiber, oklahoma City, Okla., pp. 79-101 (March 5-7, 1974).

Ketcham, B.H.. "Problems in aguatic Ecosystems, witb special Reference to Heary Metal pollution of the Marine Environment," In: Ecological Toxicology Research, Effects of Heavy Metal and Organohalogen Compounds, Proceedings of a NaTO science Committee Conference, A.D. McIntyre and C.F. Mills, (eds.), Plenum, New York, pp. 76-90 (1975).

Ketcham, B.H., V. Zitko, and D. Saward, "Aspects of Heary Metal and Organohalogen Pollution in Aquatic Ecosystems," In: Ecological Toxicology Research, Effects of Heary Metal and Organohalogen Compounds, Froceedings of a NaTo science conmittee Conference, A.D. McIntyre and C.F. Bills, (eds.), Plenum, New York, pp. 75-90 (1975).

Kim. J.H., et al.. "Protective Action of Selenium Against Mercury in Northern Creek Chubs," Bulletin of Environmental Contamination and Toxicology, 17:132 (1977):

Knauer, G.A. and J.H. Martin, "Seasonal Variations of Cadmiun, Copper, Manganese, Lead, and zinc in Water and Phytoplankton in Monterey Bay. California," Limnoloay and Oceanography, 18 (4) 597-604 (1973).

Koellirg, J.J., "Relationship of Trace Elements to Algae Growth," $\mathrm{Ph} . \mathrm{D}$. thesis, Washington State University, Pullman (1971).

Kopp, J.F. and R.C. Kroner, "Trace Metals in Waters of the U.S.: A Five Year study of Trace letals in Rivers ard Lakes in the U.S. (Oct. 1, 1962 - Sept. 30, 1967)," O.S. :Department of Interior, Federal water Pollution Control Administration, Cincinnati, ohio, 32 pp. (1968).

Koryak, M.. M.A. Shapiro, and J.I. Sykora, "Riffle Zoobenthos in Streams Receiving Acid Mine Drainage," Water Research, 6(10): 1239-1247(1972).

Rrenkel, P.A., (ed.), "Heavy Metals in the aquatic Environment," Proceedings of the International Conference, Nashville, Tenn.. Pergamon, New York, 352 pp. (1975).

Kronfield, J. and $J$. Navrot, "Transition Metal Contamination in the Qishon River System," Israeli Environmental Rollution, $6: 281-289(1974)$. 
Kuenzler, E.J.. "Elimination of Iodine, cobalt, Iron and zinc by Marine Zooplankton," Symposium on Radioecology, D.J. Nelson and F.C. Evans, (eds.), Oak Bidge, U, S. Atomic Energy Commission Technical Information Division, pp. $462-473$ (1969).

Lackey, J.B.. "Aquatic Iife in Naters Polluted by Acid Mine naste," Public Health Reports, 54:740-746 (1939).

Lande. E.. "Heavy Metal Pollution in Trondheims-fforden. Norway and the Recorded Effects on the Fauna and Flora," Environmental pollution, $11(3): 187$ (1977).

Lanford, C.E.. "Trace Minerals Affect Stream Ecology," 0 il and Gas Journal, 67. (13):82-84 (March 31, 1969).

Lansing, A.I.. "Some Effects of Hydrogen Ion Concentration, Total Salt Concentration, Calcium and citrate on Longevity and

Fecundity of the Rotifer." Journal of Experimental zoology, $92: 195-212 \cdot(1942)$.

LaRiviere, M.G., et al., "A Bibliography on Cycling of Trace Uetals in Freshwater Bcosystems," Battelle Pacific Northwest Laboratory, Richland, Hash., PNL-2706 (1978) .

Lawrence, A.W.." "Kinetics of Microbiologically Mediated Transformations of Heavy Metals in Aquatic Environments," Cornell University, Ithaca,.N.Y.. (1974). (NIIS RB-239.148)

Lee, Y.L., F.M. Patrick, and M.W. Loutit, "Concentration of Metals by a Marine Bacterium Leucothhrix and a periuinkle Melaraphạ." Proceedings of the Oniversity of otago Medical School, Dunedin, New Zealadd, 53(1):17-18 (1975).

Leland, H.V., S.N. Luoma, and D.J. Wilkes, "Heary Metals and Related Trace Elenents," Journal of the water Pollution Control Federation, $46(6): 1340-1368$ (1977).

Lewis, A.G.. P.H. Whitfield, and A. Ramarine, "Some Particulate and Soluble agents affecting the Relationship Between Metal Toxicity and organism Survival in the Calanoid copepod Euch lapanica, " Marine Biology, 17:215-221 (1972).

Lewis, S.D. and W.M. Lewis, "Effect of Zinc and Copper on the

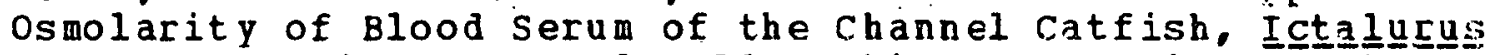
Eunctatus Fafinesque, and Golden Shiner, Notemigonus chrysoleucas vitchili," Transactions of the American Fisheries society. $100(4): 639-643$ (1971).

Liden, L.H. and E.I. Morgan, "Heavy Aetal accumulation by Fish (Teleostei) in the Ococee River: Copper Hill, Tennessee,"ASB Bulletin, 22:63 (1975). 
Lind, 0.T. and R.S. Campbell, "Community Metabolism in acid and Alkaline strip-Mine Lakes," Transactions of the American Fisheries Society, 99 (3):577-582 (July 1970).

Little, A.D.. InC.. "Water Quality Criteria Data Book - Vol. 2: Inorganic Chemical pollution of Freshwater,"U.S. Environmental Protection Agency Project 1,8010-DPV-07/71, 280 pp. (1971).

Lloyd, R., "Effect of Dissolved oxygen Concentrations on the Toxicity of Several poisons to the Rainbow Trout (Salmo gai Richardson)." Journal of Experimental Biology, 38(2):447-455 (1961).

Lloyd, R., "The Toxicity of Mixtures of zinc and Copper sulfates

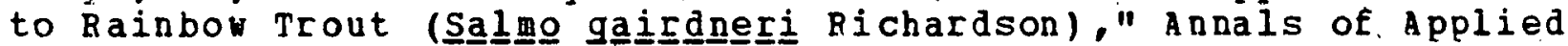
Biology. 49:535-538 (1961).

Lloyd, R., "Factors That Affect the Tolerance of Fish to Heavy Metal Poisoning," Biological Problems in Water Pollution, U.S. Public Health Service Publicatior No. 999-kP-25, Washington, D.C., pp. 181-187 (1965).

Lloyd, R. and D.W.M. Herbert, "The Effect of the Environment on the Toxicity of Poisons to Pish," Journal of the Institution of Public Health Engineers, p.p. 132-145 (July, 1962).

Iockwood, A.P.M.. (ed.). "Effects of Pollutants on Aquatic organisms," Society for Experimental Biology. Seminar Series No. II, Cambridge University Press, Cambridqe, England, 193 pp. $(1976)$.

Loeh, H.A. and W.H. Kelley, "Acute oral Toxicity of 1,496 Chemicals Force Fed to Carp." U.S. Fish and Wildife service, Special Scientific Report--Fisheries, No. 471,124 pp. (1963).

Lorz, H.W. and B.P: UcPherson, "Effects of Copper and $\mathrm{Z}$ inc on Smoltification of Coho Salmon," U.S. Environmental Protection Agency, EPA-600/3-77-032, Corvallis, Ore. (1977) . (NTIS PB-268 $304)$

Loutit, M.W., F.M. Patrick, and B.S. Malthus, "The Pole of Metal-Concentrating Bacteria in a Food Chain in a River Receiving Effluent," Proceedings of the University of otago Medical School, Dunedin, New Zealand, 51:37-38 (1973).

Lu, P., et al., "Model Ecosystem studies of Lead and Cadmium and of Urban sewage sludge Containing These elements," Journal of Enviconaental Quality. 4:505 (1975).

Lubirski, K.S., et al., "Development of Toxicity Indices for Assessing the Quality of the Illinois River," Jniversity of Illinois Hater Resource Center Report UILU-GRC-74-0096, Urbana (DEC. 1974). (NTIS PB-240 855/7ST) 
Lundgren, D.G., J.R. Vestal, and F.R. Tabita, "The Microbiology of Mine Drainage Pollution," Nater Pollution Microbiology. $R$. Mitchell, (ed.), Wiley, New York, pp. 69-88 (1952).

Luona, S.N.. "Detection of Trace Contaninant Effects in Aquatic Ecospstems," Journal of the Fisheries Research Board of Canada, $34: 436$ (1977).

Macinnes, J.B. and F.P. Thurberg. "Effects of Metals on the Behavior and Oxygen Consumption of the Mud snail," Marine Pollution Bulletin, 4(12):185-186 (1973).

McIntosh, A. and W. Bishop, "Distribution and Effects of Heary Metals in a contaminated Lake," Technical Report No. 85. OWRT/A-036-IND (1). U.S. Department of Commerce, NTIS. Sprinafield, Va. (1976).

McIntyre, A.D.. "Effects of Metals in Fertilization and Development in Fish," Proceedings of a seminar conducted by oregon state University. Corvalis (Fall 1972).

MCIntyre, A.D. and C.F. Mills, "Ecological roxicology Research-Vol. 7: Effects of Heavy Metal and Organohalogen Compounds," Plenum, New York (1975).

McIntyre, A.D. and C.F. Mills. "Effects of Heary Metal and organohalogen compounds," Ecological Toxicology Research, Vol, 7. Plenum, New York (1975).

Mckee, J.E. and H.W. Wolf, "Hater Quality Criteria, 2 nd ed.," California state Nater Resources Control Board, Publication No. 3A. 548 P. (1971).

Mackenzie, B.D., C.A. Hoppert, and R.U. Byerrum, "Studies of Cadmium and chromium Solubility and Toxicity," Journal of the american Water works Association, 49:1310 (1957).

MCKin, J.M., et al.. "Rffects of Pollution on Freshwater Fish," Journal of the water pollution control Federation. 45(6): 1370-1407 (June 1973).

Mclean, R.0. and A.K. Jones, "Studies of Tolerance to Heavy Metals, in the Flora of the Rivers ystwyth and clarach, Wales," Freshwater Biology, 5:431 (1975).

MacPhee, C. and R. Ruelle, "Iethal Effects of 1888 Chemicals Upon Four species of Fish from western North America," Oniversity of Idaho, College of Porestry, Wildlife, and Ranqe Sciences. Forest, Nildlife, and Range Experimental station, Bulletin No. 3, Moscow $(1969)$. 
Majori, I. and F. Petronio. "Marine Pollution by Metals and Iheir Accurulation.by Bioloqical Indicators (Accunulation Factor)." Revue Internationale d'Oceanographie Medicale. 31/32:55-90 (1973).

Malacea, I.. "Contributions to the knowledge of Toxic Effects of Cyanides, Ammonia, Mercury, and Arsenic on Some Fish species and on Dáahniía," Studii de Protectia di Epurarea Apelor, 7:751-792 $(1966)$.

Malaney, G.W., W.D. Sheets, and R. Quillen, "Toxic Effects of Metallic Ions on Sewage Microorganisms," Sewage and Industrizl Wastes, 31:1309 (1959).

Maloney, T.E. and M. Palmer, "Toxicity of S1x Chemical Compounds to Thirty Cultures of Algae," Water Sewage Works, 103(11):509-613 $(1956)$.

Martin, J.H.. "Possible Transport of Trace Metals via Moulted Copepod Exoskeletons," Limnology and Oceanography, 15 (5):756-761 $(1970)$.

Mathis, B.J.." "selected Metals in Sediments, Water, and Biota in the Illinois River," Journal of the water pollution control Federation, 45:1573-1583 (1973).

Mathis, B.J. and N.R. Kevern, "Distribution of Mercury, Cadmin, Lead and Thallium in a Eutrophic Lake," Hydrohiologia. $46(2-3): 207-222(1975)$.

Mayer, F.I. and J.L. Hamelink, "Aquatic Toxicology and Hazard Evaluation," American Society for Testing and Materials, STP 634 (1977).

Merlini, M.. et al.. "The Biological Pathway of zinc (65Zn) in Freshwater Fish and Its Alteration by Heavy Metals," Radionuclides in Ecosystems, Vol. I, D.J. Nelson, (ed.). Proceedings of the $3 r$ d National Symposium on Fadioecology, oak. Ridge, Tenn., pp. 285-306 (May 10-12, 1971). (Available from NTIS)

Heyers, S.P., (ed.), "Proceedings of the International Symposium on Marine Pollution Research," Louisiana state Oniversity, Center for Wetland Resources (1976).

Mierle, G. and P.M. Stokes, "Heavy Metal Tolerance and Metal Accumulation by Planktonic Algae," Trace Substances in Environmental Health - X, University of Missouri, Columbia, 113 (1976).

Mills, W. L.. "Water Quality Bioassay Using Selected Protozoa II. The Effects of Zinc on Population Growth of Euglena gracili is." Journal of Environmental Science and Health, 11 (8 and 9 ):567 (1976). 
Minkina, A.I., "On the Action of Iron and Aluminum on Fish," Water Pollution Abstracts, Vol. 23 (1050): Trudy Moskovskogo zooparka (in Russian), 3:23-26 (1946).

Monroe, G.B.. "Mining and the Environment," Mining Congress Journal, $59(9): 32-38$ (1973).

Moran. R.E. and D.A. Wentz, "Effects of Metal Mine Drainaqe on Hater Quality in selected Areas of Colorado, 1972-1973," Colorado Water Conservation Board, Water Besources Circular No. 25 (1974).

Morgan, R.P.. II.. et al., "Sublethal Effects of Baltimore Harbor Water on the White Perch, Morone amergicana, and the Hogchoker,

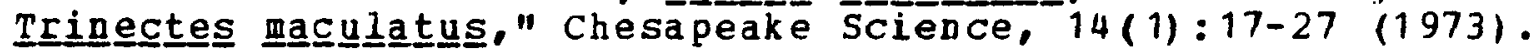

Morris, A.W.. "Trace Metal Variations in Sea Hater of the Menai Straits Caused by a Bloom of Phaeocystis," Nature, 122:427-428 (1971).

Morry. C.J. and L.J. Cole, "Iimnology and Fish Populations of Red Indian Lake, a Multi-Ose Reservoir," Technical Report No. 691. Fisheries and Marine Service, Environment Canada, St. John's, Newfoundland, (1977).

Moulton, E.Q.. "Acid Mine-Drainage problem in Ohio," Ohio state University, Engineering Experimental station Bulletin No. 165 (1957).

Murdock, H.R., "Industrial Hastes: Some Data on Toxicity of Metals in Nastes to Fish Life are Presented," Industrial Engineering and Chemistry, 45:991. (1953).

Nakani, D.V. and H.N. Korsak, "Effect of Chromium, Cadmium, and Zinc on the Rate of Photosynthesis in Short-Term Experiments," Biologicheskie nauki, 19(9): 84 (1976).

Namminga, H.E. and J. Wilhm, "Heary Metals in Water, Sediments, and Chironomids," Journal of the Yater Pollution Control

Federation, 49:1725 (1977).

Namminga, H.E., J.E. Scott, and S.L. Burks, "Distribution of Copper, Lead, and zinc in Selected Components of a Pond Ecosystem," Proceedinas of the oklahoma Academy of science, $54: 62-64(1974)$.

National Academy of Science and National Academy of Engineering. "Water Quality Criteria (1972)," U.S. Government Printing Orfice, Washington, D.C. (1974).

National Coal Association and Bituminous Coal Research, Inc., "5th and 6th Symposium on Coal Mine Drainage Research," Louisville, KY.. NCA/BCR Inc. (1974-1976). 
Natural Resource Ecoloqy Laboratory, "Toxic Effects on the Aquatic Biota from Coal and oil Shale Development: progress Report--Year I," Colorado state University, Fort Collins $(1975-1976)$.

Natural Resource Ecology Laboratory. "Ecological Fffects of coal" Strip Mining: A Bibliography with abstracts," Interaqency Energy-Environment Research and Development Program Report, Colorado State University. Bort Collins (March 1977). (NTIS FWS/OBS-77/09)

Natusch, D.F.S. "Characteristics of Pollutants from Coal Combustion and Conversion Processes," In: Toxic Effects on the Aquatic Biota from coal and oil shale Development, Quarterly Progress Report october-December"1975, Natural Resource Ecology Laboratory. Colorado state University. Fort Collins, pp. 73-90 $(1976)$.

Negilski, D.S., "Acute Toxicity of zinc, Cadmium and Chromium to the Marine Fishes, Yellow-Eye Mullet (Aldrichetta for V.) and Small-Houthed Hardyhead (Atherinasoma microstostoma Whitley)," Australian Journal of Marine and Freshwater Research, $27: 137(1976)$.

Nehring, R.B.. "Heavy Metal Toxicity in Tyo species of Aquatic Insects," M.S. thesis, Colorado state University, port collins, 82 pp. (1973).

Nehring, R.B., "Aquatic Insects as Biological Monitors of Heavy Metal Pollution," Bulletin of Environmental Contamination and Toxicology, $15(2): 147-154^{\circ}$ (1976).

Nelson, D.A., et al.. "Biological Effects of Heary Metals on Juvenile Bay Scallops, Argopecten irradians, in Short-Term Exposures," Bulletin of Environmental Contamination and Toxicology, 16:3 (1976).

Newman, J.P., JI., "Effects of Heary Metals on the Asexual Reproduction of the annelid delosoma headleyi Beddard (1838)," M.S. thesis, Virginia Polytechnic Institute and state University. Blacksburg (1975).

Nicholos, D.J.D. and A.R. Egan, (eds.), "Trace Elements in Soil-Plant-Animal Systems," Academic Press, Ner York, 417 pp. $(1975)$.

Nichols, L.E. and F.J. Bulow, "Effects of Acid line Drainage on the Stream Ecosystem of the East Fork of the obey River, Tenn.." Tennessee Academy of Science Journal, 48:3)-39 (1973).

Nielson, S.S. "Toxicity to Fish of paste Haters containing Iron and Copper," Vater Pollution Abstracts, Vol. 12 (1939): 
Nishikawa, K. and K. Tabata, "studies on the Toxicity of Heavy netals to squatic Animals and the Factors to Decrease the Toxicity III. on the Low Toxicity of Some Heary Metal complexes to Aquatic Animals." Bulletin of Tokai Regional Fisheries Research Laboratory, 58:233-241 (1969).

Nomiyama, R., "Toxicity and Physiology I. Toxicity of Heavy Metals Including Mercury." In: Heary Metals in the Aquatic Environment, Proceedings of a symposium at vanderbilt university, Dec. 4-7, 1973, Nashville, Tenn. (1973).

Nusch, E.A.. "Assessment of Detrimental Effects of Orqanic Chelators and Heavy letal Complexes by Means of Bioassays using Bacteria, Algae, Protozoa, Lower Metazoa and Fish," Zeitschrift fuer Hasser und abwasser Forschung, 10:49 (1977).

Office of Hater Research and Technology, "Acid Mine Mater, A Bibliography." Report No. WRSIC 75-202, 0.S. Department of the Interior, Washington, D.C., 564 PP. (1975). (NTIS PB-239 523)

Office of rater Fesearch and Technology, "Heavy Metals in vater (Excluding Mercury), A Bibliography, Volume 1," Report No. OWRT/WRSIC 77-201, U.S. Department of Commerce, NTIS, Springfield, $\nabla a \cdot(1977)$.

office of water Fesearch and Technology, "Heary Metals in Water (Excluding Mercury). A Bibliography, Volume 2," Report No. ONRT/WRSIC 77-205, U.S. Department of Commerce, NTIS. springfield, Va. (1977).

office of vater Fesearch and Technology, "Heavy (Excluding Mercury), A Bibliography. Volume 3," OWRT HPSIC 77-206 U. S Department of commerco. vis springfield, Va. (1977).

Office of Water Research and Technology, "Heavy Metals in Water (Excluding Mercury). A Bibliography. Volume 4," Report No. OWRT/WRSIC 77-207, 0.S. Department of Commerce, NTIS, springfield, va. (1977).

Office of water Research and Technology. "Heavy Metals in water (Excluding Mercury). A Bibliografhy, Volume 5," Report No. OWRT/WRSIC 77-208, U.S. Departmert of Commerce, NTIS. springfield, Va. (1977).

Olser, R.D. and E.H. Dettman, "Preliminary Results from a study of Coal Mining Effects on Water ouality of the Tongue River. wyoming," Hydrology and Water kesources in arizona and the Southvest, 6:59-67 (1976). 
Olson, G.. S. Turbak, and G. McFeters, "Bioassays Belated to the Effects of Coal Strip Mining and Energy Conversion on the Aquatic Microflora," Proceedings of the Symposiun on Terrestrial and Aquatic Ecological studies of the Northwest, Pheney, Wash. (Iarch $12,1976)$.

Olson, K.R. and F.C. Harrel, "Effect of Salinity on acute Toxicity of Mercury. Copper, and Chromium for Bangia ca cuneatea (Pelecypoda, Mactridae)," Contributions in Marine Science, $17: 9-13(1973)$.

O'Rear, C.H.. Jr., "Some Environmental Influences on the zinc and

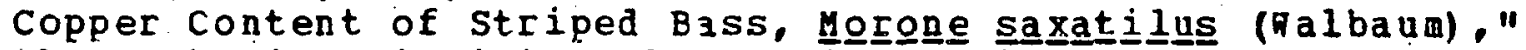
Ph.D. thesis, Virginia Polytechnic Institute and state Uriversity, Blacksburg, 70pp. (1971) .

overnell, J.. "Effects of Heavy Metals on photosynthesis and Loss of Cell potassium in. Two species of Marine Algae, Dunaliella

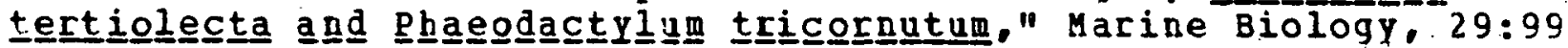
$(1975)$.

Overnell, J., "Inhibition of Marine Algal Photosynthesis by Heary Metals," Marine Biology, 38:335 (1976).

Pagenkopf, G.K., F.C. Russo, and R.V. Thurston, "Effect" of Complexation on Toxicity of Copper to Fishes, "Journal of the Fisheries Research Board of Canada, 31:462-465 (1974).

Parizek, J.. "Interactions of Selenium with Mercury, Cadmium, and Other Toxic Metals," proceedings of the symposium on Trace Element Metabolism in Animals, Oniversity of Wisconsin, Madison (1973).

Parsons, J.D.. "Effects of Acid Strip Mine Pollution on the Ecology of a Central Missouri stream," Ph.D. thesis, gniversity of Missouri, Columbia (1956).

Parsons, J.D., "Effects of Acid strip Mine Effluent on the Ecology of a Stream," Archives of Hydrobiology, 65:25-50 (1968).

Parsons, J.W. "Acid Coal Mine Pollution and Related Subjects," Journal of the Tennessee Academy of Science, $28(2): 160$ (1953).

Parsons, J.W., "Reference Material on 'Acid Coal Mine Pollution. and Related subjects," (A Selected Bibliography). Journal of the Tennessee Academy of Science, $28(2): 161-162$ (1953).

Paschal, D.C. and W. MCNamara, "Optake of Cadmium and Nickel by Sa.IVinia." Transactions of the Illinois state dcademy of science, 68:132 (1975). 
Patrick, F.M. and M.W. Loutit, "Concentration of Metals by a Water Bacterium of the Genus sphaerotilus," Proceedings of the University of Otago vedical school, Dunedin, New Zealand, $50: 30-31$ (1972).

Patrick, P.M. and M. H. Loutit, "Passage of Metals in Effluents, Through Bacteria to Higher Organisms," Water Research, 10:333-335 $(1976)$.

Eatrick, R.. "Effects of Trace Metals in the Aquatic Ecosyste⿴囗" American Scientist, 66:185-191 (March-April 1978).

Patrick, R.. T. Bott, and R. Larson. "The Role of Trace Elements in Management of Nuisance Growths," Environmental Protection Technology Series, Corvallis, Ore., U.S. Environmental protection Agency, E PA $-660 / 2-75-008$ (1975).

Patrick, R..J. Cairns, Jr., and A. Scheier, "Relative Sensitivity of Diatoms, Snails, and Fish to Tuenty Common Constituents of Industrial Nastes," Progressive Fish-culturist, $30(3): 137-140$ (1968).

peden, J.D.. et al.. "Heavy Metals in Somerset Marine Organisms," Marine Pollution Bulletin, 4:7-9 (1973).

Pentreath, R.J.. "The Accumulation and Retention of $65 \mathrm{z}$ and 54 in by the Plaice, pleuronectes platessa L." Journal of Fxperimental Marine Biology and Ecology, 12(1):1-18 (1973).

Pentreath, R.J., "The Accumulation from Hater of $65 \mathrm{zn}, 54 \mathrm{Mn}$, $58 \mathrm{Co}, 59 \mathrm{Fe}$ hy the Mussel Mytilus eduliss," Journal of the Marine Bioloqical Association of the United Kingdom, 53:127-143 (1973).

Perrin,: D. D. and I.G. Sayce; "Computer Calculation of Equilibrium Concentrations in ixtures of Metal Ions and Complexing species," Talanta, 14:833-842 (1967).

Persoone, G. and G. Oyttersprot, "Influence of Inorganic and Organic pollutants on the Rate of Reproduction of a Marine Hypotrichous Ciliate: Euplotes aㅡ믄 Muller," Revue Internationale d'Ocea nographie Médicale, 37/38:125 (1975).

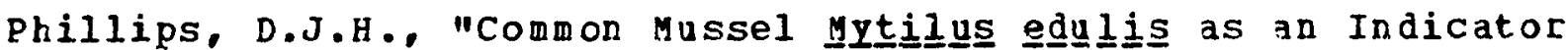
of Poliution by zinc, cadmium, Lead, and copper I. Fefects of Environmental Variables on Uptake of Metals," Marine Biology; 38:59-69 (1976).

Phillips, D.J.H., "The Ose of Biological Indicator Organisms to Monitor Trace Metal Pollution in Marine and Estuarine Environments," Environmental pollution, 13:281 (1977).

Pickering, Q.H. and C. Henderson. "Acute Toxicity of Some Heary Metals to Different Species of Warm Water Fishos," International Journal of Air and Water Pollution, 10:453-463 (1966). 
Pittwell, L.R.. "Metals Coordinated by Ligands Normally Fount in Natural waters," Journal of Hydrology, 21:301-304 (1974).

Poon, C.P.C. and K.H. Bhayahi, "Metal Toxicity to sewage organisms," proceedings of the American Society of Civil Engineers, Jourral of the Sanitary Engineerind Division, Vol. 97 $(1970)$.

Porter, K.R. and D.E. Hakanson, "Toxicity of Mine-Drainage to

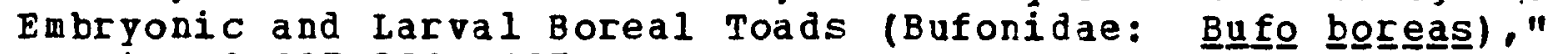
Copeia, 2:327-331 (1976).

Prescott, L.H., et al.. "The Effects of Pesticides, Polychlorinated Biphenyls and Metals on the Growth and Reproduction of Ecanthra amoeba castellanii." Bulletin of Environmental Contamination and Toxicology, 18(1):29 (1977).

Pringle, B.H., et al., "Trace Uetal Accumulation by Bstuarine Hollusks," Journal of the Sanitary Bngineering Division, American Society of Civil Engineers, 94:455 (1968).

"proceedings of the 1st Syposium on acid Mine Drainaqe Research," Ohio River Valley Nater Sanitation Commission, Cincinnati, 232 pp. (1965).

"Proceedings of the 2nd Symposiur on Coal Mine Drainage Research," Ohio River Valley water Saritation Commission, Cincinnati, 406 pp. (1968).

"Proceedings of the 3rd Symposium on coal Mine Drainage Research," Ohio River Valley Nater Sanitation Commission, Cincinnati (1970).

Rabe, F.H.. R.C. Wissmar, and K.F. Hinter, "Plankton Populations and Some Effects of Mine-Drainage on Frimary productivity of the Coeur d'alene River, Delta, and Lake," Oniversity of Idaho, yater Resources Institute Completion Report, Hoscow, 20 pp. (1973). (NTIS PB-216 211)

Ragsdale, E.L. and F.J. Bulow, "Possible Effect of Acid Mine Drainage on the water Quality and Fish Population of Dale Hollow Reservoir. Tennessee and Kentucky." Journal of the Tennessee Academy of Science, 50 (3):91-95 (1975).

Ralston, S., et al., "The Bcological Effects of coal Strip-Mining: A Bibliography with Abstracts, "Report No. FWS/08S-77/09, U.S. Department of the Interior, Office Research and Development, Fish and Wildlife service, Ft. Collins, Colo. (1977).

Ramamoorthy, S. and D.J. Kushner." "Bindinq of Mercuric and other Heavy Metal Ions by Microbial Growth Media," Microbial Ecoloyy. $2: 162$ (1975). 
Rashid, M.A. and J. Leonara, "Modifications in the solubility and Precipitation Behavior of various Metals as a Result of Their Interaction with Sedimertary Humic Acid," Chemical Geology. 11:89-97 (1973) .

Ray, S. and W. White, "Selected Aguatic plants as Indicator Species for Heary Metal pollution," Journal of Environmental. Science and Health, A-11(12):717-725 (1976).

Raymont, J.E.G. and J. Shields, "Toxicity of Copper and Chromi um in the Marine Environment," davances in Hater Pollution Research, E. A. Pearson, (ed.). Macmillan, New York (1964).

Rehwoldt, R., G. Bida, and B. Nerrie, "Acute Toxicity of Copper, Nickel and Zinc Ions to some Hudson River Rish Species," Bulletin of Enviconmental Contamination and Toxicology, $6(5): 445-448$ (1971).

Rehroldt, R., et al., "Effect of Increased Temperature Jpon the Acute Toxicity of Some Heavy Metal Ions," Bulletin of. Environmental Contamination and Toxicology, 8(2):91-96 (1972).

Rehwoldt. R., et al.. "The Acute Toxicity of Some Heary Metal Ions Toward Benthic Organisms," Bulletin of Environmental contauination and moxicology, $10(5): 291-294$ (1973).

Reish, D.J., et al.. "Induction of Abnormal polychaete Larvae by Heavy Metals," Marine Pollution Bulletin, 5(8):125-126 (1974).

Reish, D.J., et a 1.. "The Effect of Heary Metals on Iaboratory Populations of. Two Polychaetes with comparjons to the water Quality Conditions and standards in southern California Marine Waters," Water Pesearch, 10:299-302 (1976).

Richards, J.N.. "Studies of Phytoplankton and soil algae of Tyo Acid Strip Mine Impoundments in Tuscarawas County, Ohio," M.A. thesis, Kent state University. Kent, Ohio, 56 pp. (1974).

Ridley, W.P., et al.. "Biomethylation of Toxic Elements in the Environment." Science, 197:329 (1977).

Riley, C.V., "Fcology of water Areas Associated with coal Strip-Mined Lands in Ohio," Ohio Journal of Science, $60(2): 106-121$ (1960)

Riley, J.P. and I. Roth, "Distribution of Trace Elements in Species of Phytoplankton Grown in Culture," Journal of the Marine Biological Association of the united, kingdom, 51:63 (1971).

Roales, R.R. and A. perlmutter, "Toxicity of Methvlmercury and Copper, Applied Singly and Jointly to the Blue Gourami, Trichogaster trichopterus," Bulletin of Environaental Contamination and Toxicology, 12(5):633-639 (1974). 
Roales, R.R. and A. Perlmutter, "The Effects of Sub-Lethal Doses of Hethylmercury and Copper Applied Singly and Jointly, on the

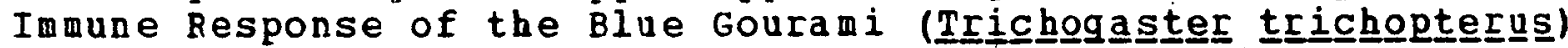
to Viral and Bacterial Antigens," Archives of Environmental Contamination and Toxicoloqy, 5:325-331 (1977).

Roback, S.S. and J.W. Richardson, "Effects of Acid Mine Drainage on Aquatic Insects." Proceedings of the Academy of Natural Sciences, Philadelphia, 121:81 (1969).

Rosco, J.J. and J.H. Rachlin. "Effects of Copper, Zinc, Cobalt, and Manganese on the Growth of the Marine Diatom Nㅡ느므믐 closteri $(1975)$.

Rothstein. A., "Toxicology of the Minor Metals, "Oniversity of Rochester, New York, Atomic Energy Commission Profect $0 R-262$ (June 5, 1953).

Rudolfs, N.. et al., "Review of Literature on Toxic Materials. Affecting Sewage Treatment Processes, Streams, and B. O.D. Determinations," Sewage and Industrial Hastes, $22(9): 1157-1154$ (1950).

Ruesink, B.G. and L.I. Smith, Jr., "Relationship of the 96-Hour LC50 to the Lethal Threshold Concentration of Hexavalent Chromium, Phenol, and Sodium Pentachlorophenate for. Fathead Minnows (Pimephales promelás Bafinesque)." Iransactions of the American Fisheries society, 3:507-569 (1975).

Ruthven, J.A. and J. Cairns, Jr., "Response of Fresh-water protozoan artificial Commuities to Metals," Journal of Protozoology, 20(1):127-135 (1973).

Rzewuska, E. and A. Wernikowska-Ukleja, "Research on the

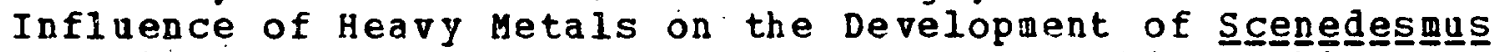
guadricanuda (Turp.) Breb. I. Mercury." Polskie Archivum Hydrobiologie, 21(1):109-117 (1974).

Saliba, L.J. an R.M. Krzyz, "Effect of Heary Hetals on Hatching of Brine Shrimp Eggs," Marine Pollution Bulletin, 7(10):181-182 $(1976)$.

Salzinger, K.. et al.. "Behavior of the Goldfish as an Early Warning system for the Presence of pollutants in Water." Journal of Environmental Systems, 3(1):27-40 (Spring 1973).

Sanborn, N.H., "The Lethal:effect of certain Chemicals on Fresh Nater Fish," Canning Trade, 67 (49): 10-12 (19.45).

Sartory. D.P. and B.J. Lloyd, "The Toxic Effects of selected

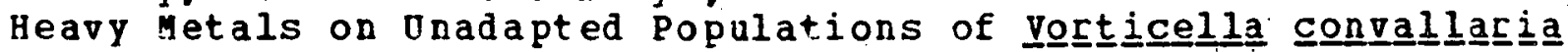
Var Similis," water Research, 10:1123 (1976). 
Saunders, R.I. and J.B. Sprague, "Effects of Copper-zinc Mining Pollution on a Spawning Migration of Atlantic Salmon," Water Research $1(6): 419-4.32$ (1967).

Sauter, S.. et al.. "Effects of Exposure to Heavy Metals on selected Freshwater Fish, Toxicity of Copper, Cadmium, Chromium and Lead to. Eggs and Fry of Seven Fish species," U.S. Environmental Protection Agency Report EPA-600/3-76-105, Duluth, Minn. $75 \mathrm{pp}$. (1976).

Savage, N.I. and F. Rabe, "Effects of Mine and Domestic Wastes on Macroinvertebrate Community Structure in the Coeur D'Alene River." Northwest Science, 47 (3):159-168 (1973).

Savannah River Fcology Laboratory, "proceedinas of the $5 \mathrm{th}$ Symposium on Energy and Environmental Stress in Aquatic Systems," Augusta, Ga.. Nov. 2-4, 1977, J.H. Thorp and J.W. Gibbons, (eds.), USDOE Sympoșium series CONF-771114(1978).

Scheier, A. and P. Kiry. "A Discussion of the Effects of cartain Potential Toxicants on Fish and Shellfish in the Upper Delaware Estuary," Academy of Natural Sciences of Philadelphia, Penn. (Dec. 1973). (NTIS PB-231 423)

Schindler, J.E. and J.J. Alberts, "Behavior of Mercury, Chromium, and Cadmium in Aquatic systems,"U.S. Environmental Protection Agency, EPA-600/3-77-023, Athens, Ga. (1977).

Schmidt-Nielsen, B.. "Osmoregulation: fffect of Salinity and Heavy Metals," Proceedings of the American society of Experimental Biology, 33 (5): 213̣7-2146 (1974).

Schneider, R.F., "Impact of Various Heavy Metals on the Aquatic Environment," U.S. Environmental protection Agency, water Quality office Technical Report No. 2, 22 pp. (Feb. 17, 1971).

Schubert, J.P., F.D. Olsen, and S.D. Zellmer, "Mcnitoring tha Effects of Coal Refuse Disposal and Reclamation on Water Quality in Southwestern Ilinois," In: proceedings of the 4th Joint Conference on sensing of Environmental pollutants, American Chemical Society, pp. 724-731 (1978).

Schweiger, G., "Toxic Action of Heary Metal Salts on Fish and orqanisms on which Fish Feed," Archiv fuer Pischereiwissenschaft, $8: 54-62(1957)$.

seifriz, W.. "Toxicity and the chemical Properties of Ions," Science, 110:193-196 (1949):

Sellers, C.M.. A.G. Heath, and M.I. Bass, "The Effect of Sublethal concertrations of copper and $z$ inc on Ventilatory Activity. Blood oxygen and pH in fainbow Trout (Salmo gairdneril)," Water Research, 9:401-408 (1975). 
Shaikh, Z.A. and.0.J. Lucis, "Biological Differences in Cadmium and zinc Iurnover," Archives of Environmental Health, 24:410-418 $(1972)$.

Sharenkova; K. and K. Gabrorski, "Effect of Molybdenum phosphate Glasses Containing Trace Elements on the productivity of sćenedesmus açutus " " Doklady sel'skokhozyaistvennoi akademii (DSSR), 6:1 (1973).

Shar, T.I. and V.M. Brown, "Heary Metals and the Fertilization of Rainbow Trout eggs," Nature, 203 (5291):251 (1971).

Shaw, H.H.R.." "cation Toxicity and the stability of Transition-Meta 1 Complexes," Nature. 192:754-755 (1961).

Shaw. W,H.R. and B. Grushkin, "The Toxicity of Metal Ions to Aguatic Organisms," Archives of Biochemistry and Biophysics, $67(2): 447-452$ (1957).

Shearer, R.E. and M.A. Everson, "Study of Bacteriophage in Controliing acid Mine later," Symposium on Acid Mine Drainage Research, Pittsburgh, pp. 23-34 (1965).

Sheets, D. " "Toxicity. Studies: of Metal-Finishing Hastes," Sewage and Industrial wastes, $29(12): 1380-1384$ (1957).

Sheridan, J.R., "Fish Population: Influences of Strip Mining on the Hydrobiologic Environment of parts of Beaver Creek Basin. KY.. 1955-1966," U.S. Geological Survey Professional Paper No. $427-\mathrm{C}, \mathrm{pP}, \mathrm{C} 50-\mathrm{C} 53(1970)$.

Shuettle, K.H., (ed.), "Trace Element Problems in Nature, A Symposium," University of Cape Town. Department of Botany, South Afica, 55 pp。(1959).

Shukla, S.S. and H.Y. Leland, "Heary Metals: A Review of Lead," Journal of the water Pollution Control Federation, $45(6): 1319-1331$ (1973)。

Shuster, C. and F.H. Pringle, "Effects of Trace Metals on Estuarine Mollusks," Proceedings of the 1st Mid-atlantic Industrial Waste Conference, Oniversity of Delaware, Newark, pp. 285-304 (1968).

Si.ck, L.B. and H.I. Windon, "Effects of Environmental Levels of Mercury and Cadmium in Rates of Metal uptake and Grouth Physiology of Selected Genera of Marine Phytoplankton," Proceedings of the Symposium on Mineral cycling in southeastern Eccsystems, Augusta, Ga., pp. 239-249 (1975).

Sigel, H., (ed.), "Metal Ions in Biological Systems," Marcel Dekker, New York, $416 \mathrm{pp}$. (1976). 
Silaichuk, E.V.. "The Effects of Waste Waters Containing Cyanides and Hexaralent Chromium on the viability of certain Aquatic organisms," Gigiena i Sanitariya, 34:78-79 (1969).

Sims, R.R. and B.J. Presley, "Heavy Metal Concentrations in organisms from an Actively Dredged Texas Bay," Bulletin of Environmental Contamination and Toxicology, 16:520 (1976).

Singer, P.C.. (ed.), "Trace Metals and Hetal-organic Interactions in Natural waters," Ann Arbor science Publishers, Ann Arbor, Mich.. 380 pp. (1973).

Singh, S.B., S.C. Banerjee, and P.C. Chakrabarti, "preliminary observations on Response of Young. Ones of Chinese Carps to Various Physico-Chemical Factors of Nater, " Proceedings of the National. Academy of Sciences, India, 37 (111):320-324 (1967).

Sinha, E., Metals as Pollutants in Air and water: An Anotated Bibliography," Ocean Engineering Information Service, LaJolla; Calif. (1972).

Sizemore, D.R.. "Effects of Acid Mine Drainage on Chestnut Creek. virginia." M.S. thesis, Virginia Polytechnic Institute and State Oniversity, Blacksburg, 96 P. (1973).

Skidmore, W.J., "An Investigation of Carbon Dioxide, Ammonia, and Hydrogen Sulfide as Pactors Contributing to Fish Kills in Ice Covered lakes," Progressive Fish-Culturist, 19:124-127 (1957).

slatkin, D.. "Comparison of the Lethality of Various Combinations of Heary Metals and Nater Temperature to Jurenile Rainbow Trout," Battelle Pacific Northrest Laboratory, Richland, Washington, Nuclear Science Abstracts, $28(6): 15127$ (1973).

Slonim, C.B. and A.R. Slonia, "Effect of Water Harạness on the Tolerance of the Guppy to Beryllium Sulfate." Bulletin of Enviconmental Contamination and Toxicology, $10(5): 295-301$ (1973).

Smith, E.J., "Effects of Iime Neutralized Iron Hydroxide Suspensions on Selected Species of North American Fish." Ph.D, thesis, University of Pittsburgh, Graduate School of public Health (1973).

Smith, E.J. and J.I. Sykora, "Early Developmental Effects of Iime-Neutralized Iron Hydroxide Suspensions on Brook Trout and Coho Salmon " Transactions of the American Fisheries societya 105: 308 (1976).

Smith, R.H. and D.G. Frey, "Acid Mine pollution Effects on Lake Biology," U.S. Environmental Protection Aqency, water pollution Control Research Series Report EPA-18050-EEC-12/71, 132 pD. (1971). 
Sodergren. S. "Ecological Bffects of Heavy Metal Discharge in a Salmon River," Drottningholm, Sweden. Institute of Freshwater Research, Report 55:91 (1976).

Sparks, R.E., J. Cairns, Jr., and F.B. Cross, "Some Effects of a Neutral Mixture of Calcium oxide and Sulfuric Acid on Channel

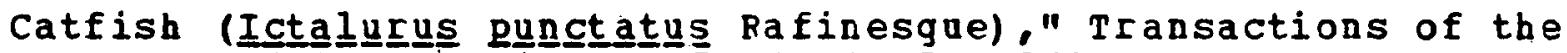
Kansas academy of science, $72(1): 1-15$ (1969).

Spaulding. W.M., Jr. and F.D. Ogden, "Effects of Surface Mining on the Fish and Wildife Resources of the united States," 1.5 . Bureau of Sport, Fisheries, and vildife Resources, publication No. $68,47 \mathrm{pp}$. (1968).

Spehar, R.I., "Cadmium and zinc Toxicity to Jordanella faloridage (Goode and Bean): Effects on Growth, Reproduction, Survival, and Behavior." Thesis, University of Minnesota (1974).

Spehar, R.L.. "Cadmium and zinc Toxicity to flagfish, Juodangella floridae," Journal of the Pisheries Research Board of Canada, 33:1939-1945 (1976).

Spehar, R.I.. "Cadmium and Zinc Toxicity to Jordanell O.S. Environuental Protection AgedCy Feport EPA-600/3-76/096

$(1976)$.

Sprague, J.B., "Avoidance of Copper-zinc Solutions by roung Salmon in the Iaboratory," Journal of the Hater Pollution Control Federation, 36:990 (1964).

Sprague, J.B., "lethal Concentrations of Copper and zinc for Young Atlantic Salmon," Journal of the Fisheries Research Board of Canada, 21:17-26 (1964).

sprague, J.B.. "Effects of Sublethal concentrations of $z$ inc and copper on Migration of atlantic salmon," Biological problems in Water pollution. Third seninar, Cincinnati, Ohio, o.s. Publiz Health Service Publishing No. 999-NP-25, pp. 332-333 (1965) .

Sprague, J.B.. "Promising Anti-Pollutant: Chelating Agents NTA Protects Fish from Copper and Zinc," Nature, 220:1345-1346 (1968).

Sprague, J.B., "Heasurement of Pollutant Toxicity to Pish III. Sublethal Effects and "Safe' Concentrations," "ater Research, $5: 245-266$ (1971).

Sprague, J.B. and D.E. Drury, "Avoidarce Reactions of Salmonid Fish to Representative Pollutants," Advances in vater Pollution Research, Proceedings of the 4 th International conference held in Prague, 1969, Pergamon, Oxford, England, Vol. 1, pp. 169-179 (1969). 
Sprague, J.B. and B.A. Ramsay. "Lethal Levels. of Mixed Copper-zinc Solutions for Juvenile Salmon," Journal of the Fisheries Research Board of Canada, 22:425 (1965).

Sprague, J.B., P.F. Flson, and R.I. Saunders, "Sublethal Copper-zinc pollution in a Salmon River - A Field and Laboratory study." International Journal of Air and water pollution. $9: 531-543(1965)$.

Stanley, R.A.. "Toxicity of Heavy Metals and Salts to Eurasian

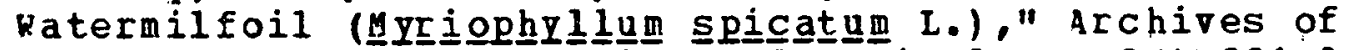
Environmental Contamination and Toxicologr. 2 (4) $331-341$ (1974).

Stebbing, A.R.D., "The Effects of Low Metal Levels on a Clonal Hydroid," Journal of the Marine Biological Association of the onited Kingdom, 55(4):977-994 (1976): Biological Abstracts, Vol. 63. No. $72216(1977)$.

Stein, J.N. and M.D. Miller, "An Investigation into the Effects of a Zinc-Lead Mine in the aquatic Environment on Great slave Lake," Technical Report, Resource Management Branch, Department of the Environment Fisheries and Marine Service, Hinnipeg. Manitoba, $56 \mathrm{pp}$. (1972).

Stiles, ." "Trace Elements in plants and Aninals," Cambidge university press, Cambridge, England, 154 pp. (1951).

Stokes, P.M., "Optake and Accumulation of Copper and Nickel by Metal-Tolerant strains of Scenedesmus," Verhandlungen Internationale vereiniqung fur Theoretische und Angewandte Limologie, 19:2128-2137 (1975):

Stokes, P.M." "Adaptation of Green Algae to High Ievels of Copper and Nickel in Aquatic Environments." International Conference on Heavy letals in the Environment, Vol. IJ. Pathways and Cycling, Institute of Environmental studies, University of Toronto, 137 (1977).

Stokes, P.M.. T.C. Hutchinson, and K. Krauter, "Heavy Metal Tolerance in Algae Isolated from Polluted Lakes Near the Sudbury. ontario Smelters," Mater Pollution Research in Canada, 8:178-201 (1973).

Stokes, P.M., T.C. Hutchinson, ard K. Krauter, "Heary Metal Tolerance in alqae Isolated. From Contaminated Lakes Near Sudbury. Ontario," Canadian Journal of Botany, 51(11):2155-2168 (1973).

Sudo, R. and S. Aiba, "Effect of Copper and Hexavalent chromium on the Specific Growth Rate of Ciliata Isolated from

Activated-Sludge," Rater Research, 7(9):1301-1307 (1973). 
Sullivan, G.W.. "Acute Bioassays for Assessing the roxicity of Six Heavy Metals and Pactors Atfecting zinc Toxicity to the Rotifer, Philodina (near Acuticornis)." M.S. thesis, virginia Polytechnic Institute and state oniversity, Blacksburg (1973).

Sullivan, G. H., A.L. Buikema, and J. Cairns, Jr., "Acute Bioassays for the Assessment of Heavy Metal pollution osing the Freshwater Iittoral Rotifer Philodinㅡㅁ sp. " virginia Journal of science (abstract) (1973).

Sullivan, J. and T.C. Cheng, "Heary Metal Toxicity to Bionghalaria globrata (Holiusca: Pulmonata)," Annals of the New York Acadeny of Science, 266:437 (1975).

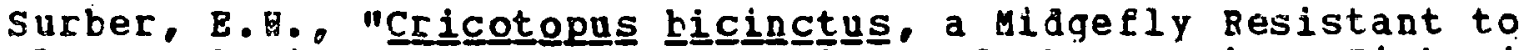
Electroplating Bastes," Transactions of the American Fisheries society, $88(2): 111-116$ (1959): Biological Abstracts, 35:9533 $(1960)$.

Surber, E.H.. "Water Quality Criteria for Freshwater Fishes," proceedings of the $16 \mathrm{tb}$ Annul Conference of the Southeastern Association of Game Fish Commerce, pp. $435-436$ (1965).

Sykora, J.L., E.J. Smith, and M.A. Shapiro, "Chronic Effect of Ferric Hydroxide on Certain Species of Aquatic Animals," proceedings of the $4 \mathrm{th}$ Symosium on Coal Mine Drainage Research, Mellon Institute, Pittsburgh, p. 347 (April 26-27, 1972).

Sykora, J.L., E.J. Snith, and M. Synak, "Effect of lime Neutralized Iron Hydroxide Suspensions on Juvenile Brook Trout (Sal relinuus fongtinalis)." Mater Research, 6(8):935-950 (1972).

Sykora, J.I., et al., "Some observations on Spawning of Brook Trout (Salvelinus fontinalis, itchill) in lime Neutralized Iron Hydroxide Suspensions," Hater Research, 9 (4):451-458 (1975).

Tabata. K., "Studies on the Toxicity of Heary Metals to squatic Animals and the Factors to Decrease the Toxicity $I$. On the Formation and the Toxicity of precipitates of Heavy Metals," Bulletin of Tokai Regional Fisheries Research Laboratory. $58: 203-214(1969)$.

Tabata, K.. "Studies on the Toxicity of Heary Metals to Aquatic Animals and the Factors to Decrease the Toxicity II. Antagonistic Action of Hardness components in water on the Toxicity of Heavy Metal Ions," Bulletin of Tokai Regional Fisheries Research Laboratory, 58:215-232 (1969).

Tabata. K.." "Studies on the Toxicity of Heary Metals to Aquatic Animals and the Factors to Decrease the Toxicity. IV. on the Relatior Between the Toxicity of Heavy Metals and the Quality of Environmental hater." Bulletin of Tokai Regional Fisheries Research Laboratory, 58:243-253 (1969). 
Tarzwell, C.M. and A.R. Gaufin, "Some Important Biological Effects of Poliution often Jisregarded in Stream Surveys," Proceedings of the $8 t h$ Industrial Waste Conference, Purdue University. Lafayette, Ind. (1953).

Tarzwell, C.M. and C. Henderson, "Toxicity of Some of the Less Common Hetals to Fishes," Transactions of the seminar on sanitary Engineering Aspects of the Atomic Energy Industry. Bobert A. Taft Engineerina Center Report TID-7517 (1956):

Tarzwell, C.M. and C. Henderson, "Toxicity of Less Common Metals to Fishes," Industrial wastes, 5:12 (1960).

Taylor, D.. "A Summary of the Data on the roxicity of various Materials to Aquatic Life," Imperial Chemical Industries, vols. 1 and 2 (1977).

Terhaar, C.J., et al.. "A Laboratory Model for Evaluating the Behavior of Heavy Metals in an Aquatic Environment," water Fesearch, 11:101 (1977).

Thomas, A., "Effects of Certain Metallic Salts Upon Pishes," Transactions of the american Fisheries Society, $44(1): 120-124$ (1915).

Thormann, D.. "Effects of Cadmium and Lead Upon the Indigenous Heterotrophic Microflora in the Aqueous Environiment of $t$ he Brackish Estuary water of the River Heser, "Veroeffentiichungen des Instituts fuer Heeresforschung in Bremerhaven, 15:237 (1975).

Thorp, V.J. and P.S. Lake, "Toxicity Bioassays of Cadmium on selected Freshwater Invertebrates and the Interaction of cadmium

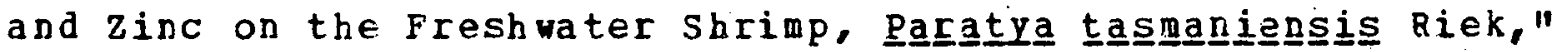
Australian Journal of Maring and Freshwater Research, $25(1): 97-104$ (1974).

Thurberg. F.P.. M.A. Dawson, and B.S. Collier, "Effects of Copper and Cadmium on Osmoregulation and Oxygen consumption in Two

Species of Estuarine Crabs," Marine Biology, 23:171-175 (1973).

Thurston, R.V., R.K. Skogerboe, and R.C. Russo, "Toxic Effects on the aquatic Biota from Coal and oil shale Development. Quarterly Proqress Report July-September 1975," Colorado state university Natural Resource Ecology I aboratory. Fort Collins, and Montana State University $\mathrm{F}$ isheries Bioassay Laboratory, Bozeman, Internal -Project Report No. 2, 230 pp. (1975).

Thurston, R.V.. F.K.' Skogerboe, and R.C. Russo, "moxic Effects on tbe Aquatic Biota from Coal and oil shale Development. Quarterly Proqress Report Sumary. July-september 1975." Colorado State university Natural Resource Ecology Laboratory, Fort Collins, and Montana State University Fisheries Bioassay Laboratory, Bozeman, Internal project Report No. 4, 19 pp. (1975). 
Thurston, R.V.. R.K. Skogerboe, and R.C. Russo, "Toxic Effects on the Aquatic Biota from Coal and oil shale Development. Quarterly Proqress Report, October-December 1975," Colorado State

Oniversity Natural Pesource Ecology Laboratory, Fort Collins, znd Montana State University Fisheries Bioassay Laboratory, Bozenan, Internal project Report No. 5, 199 pp. (1975).

Thurston, F.V., R.K. Skogerboe, and R.C. Russo, "Toxic Effects on the squatic Biota from Coal and oil shale Development. Quarterly Progress Report sumary, Octoher-December 1975," Colorado state University Natural Resource Ecology Laboratory, Fort Collins, and Montana state oniversity Pisheries Bioassay Laboratory, Bozeman, Internal Project Report No. 6, 15 pp. (1975).

Thurston, R.V.. P.K. Skogerboe, and R.C. Russo, "Toxic Effects on the Aquatic Biota from Coal and oil shale Development. Quarterly Progress Beport, January-March 1976," Colorado state university Natural Resource Ecology Laboratory, Fort Coliins, and Montana State oniversity Fisheries Bioassay Laboratory. Bozeman, Internal Project Report No. 7, $191 \mathrm{pp}$. (1976).

Thurston, R.V., R.K. Skogerboe, and R.C. Russo, "Toxic EEfects on the quatic Biota from coal and Cil Shale Development. Quarteriy Progress Report Summary. January-March 1976," Colorado State University Natural Resource Ecology laboratory. Fort Collins, and Montana state University Fisheries Bioassay Laboratory, Bozeman, Internal Project Feport No. 8, 23 pp. (1976).

Thurston, R.V., et al., "Toxic Effects on the Aguatic Biota from coal and oil shale Development: Progress Report--Year 1," Colorado State University Natural Resource Ecology Laboratory, Fort Collins, and Montana state University Fisheries Bioassay Laboratory, Bozeman (July 1975-June 1976).

Tkachenko, V.N., et a 1.. "Method of Toxicological Experiments and Some Results of Toxicological Effects of Heavy Metals on Marine and Freshwater Monocell Algae," Trudy Vsesoyuznoqo

Nauchno-Issledovatel skogo Instituta Morskogo Rybrogo khozyaistra i okeanografic, 100:63 (1974).

Tomkienicz, S.M.. Jr. and W.A. Dunson, "Aquatic Insect Diversity and Biomass in a Strea uarginally polluted by Acid strip Mine Drainage," Water Research, 11:397-402 (1977).

Tomoyeda, M., et al., "Recovery of Heavy Metal Compounds by Hicroorganisms II. Incorporation of Phenylmercuric and Mercuric Acetate into Microorganisms Tolerant to Then." Nippon Noqei Kagaku Kaishi (ir Japanese), 47:51 (1973).

"Toxicity in the Aquatic Environment," Proceedings of the 10th Pacific Northwest Symposium on Nater Pollution Research,

Portland, Ore. (1961). 
Trollope, D.B. and B. Evans, "Concentrations of Copper, Iron, Iead, Nickel and $\mathrm{Zinc}$ in Freshwater Algal Blooms," Environmental pollution, 11:109-116. (1976).

Turnbull, H...J.G. DeMann, and R.F. Weston, "Toxicity of Various Refinery aterials to Freshwater Fish," Industrial Engineering and Chemistry. $46(2): 324-333$ (1954).

Turner, HoR.. "Rffects of Acid Mine Pollution on the Pish Population of Goose Creek, Clay County, Kentucky," Progressive Fish-Culturist, 20:45-46 (1958).

ukeles, R., "Growth of Pure Cultures of Marine Phytoplankton in the Presence of Toxicants," Applied Microbiology. 10(6):532.-537 (1962).

0.S. Department of the Interior, "Surface Mining and our Environment," o.S. Government printing office, Washington, D.C. $(1967)$.

0.S. Department of the Interior. "Trace Elements in water - A Bibliography," office of Water Resources Research Report WRSIC 71-202, 286 pp. (June 1971). (NTIS PB 201266 )

0.S. Department of the Interior. "Arsenic and lead in Hater - A Bibliography," office of Nater Resources Research Report HSIC 71-209, 82 pp. (Sept. 1971). (NTIS PB 202578 )

v.S. Environmental Protection Agency, "Quality Criteria for Water." Office of Hater Planning and standards Report EPA 440/9-76/023, 537 pp. (1976).. (NTIS PE-263 S43/3ST).

U.S. Federal water pollution Control Administration, "strea Pollution hy Coal Mine Drainage in Appalachia," Acid Mine Drainage in Appalachia, Revised Edition, Appendix C - Attachment A. O.S. Government Printing office, Washington, D.C., 261 pp. (1969).

Van Hook, F.I., "Potential Health and Environmental Effects of Trace Elements and Radionuclides from Increased Coal Utilization," Report prepared for the president's committee on Healtb and Ecological Effects of Increased Coal otilization, Environmental Sciences Division, Oak Eidge National Laboratory, Oak Ridge, Tenn. (Nov. 21. 1977).

Van Loon, J.C. and R.J. Beamish, "Heavy Metal Contamination hy Atmospheric Fallout of Several Flin Flon area liakes and the Relation to Fish Populations," Journal of the Fisheries Research Board of Canada, 34:899 (1977).

Varanasi, D., P.A. Robisch, and D.C. Malins, "Structural Alterations in Fish Epidermal Mucus Produced by waterborne Lead and Mercury." Nature, 258(5534):431-432 (1975). 
Vaughan, B.E.. et al.. "Review of Potential Impact on Health and Environmental Quality from Metals Entering the Environment as a Result of Coal Utilization," Battelle Pacific Northwest Laboratories Energy Program Report, Richland, Rash., pp. 1-75 (1975).

Vernberg, F.J., et al.. (eds.), "physioloqical Responses of Marine Biota to Pollutants," Academic Press, New York (1977).

Wahalen, S.C., P.J. Garrison, and R.W. Gregory, "Limnology of the Tongue River Reservoir: Fxisting and potential Impacts of coal Strip Mining," Decker Coal Co., 2nd Progress Report, Sheridan, Wyo.. 70 pp. (April 1976).

Naldichuk, M.." "Some Biological Concerns in Heavy Metals Pollution," In: Pollution and Physiology of Marine Organisms. F.J. Vernberg and W.B. Vernberg, (eds.), Academic Press, New York. pp. 1-57 (1974).

Nalker, J.B.. "Inorganic Microuutrient Reguirements of Chliogrellia. I. Requirements for Calcium (or strontiumi. Copper, and Molybdenum," archives of Biochemistry and Biophysics, 46:1-11 (1953).

Walker, W.T., et al., "A Computer Simulation of the Effects of Superimposed Mortality Due to Pollutants on Populations of Fathead Hinnows (Pimephales pronelass). "journal of the pisheries Research Board of Canada, 28:1107-1112 (1971).

Wallen, I.E.. H.C. Greer, and R. Lasater, "Toxicity to Gąmbuaiaa affinis of Certain Pure Chemicals in Turbid Waters," Sewage and Industrial wastes, 29 (66):695-711 (1957).

Hard, J.V. and S. Canton, "Effects of Coal Mine-orainage on the Macroinvertebrates of Trout creek, Colorado," Colorado State University Natural Resource Fcology Laboratory, Fort Collins, and Montana state University Fisheries Bioassay I aboratory. Bozeman, Interal Project Report No. 2, pp. 185-204 (1975).

Ward, J.V. and S. Canton, "Effects of Coal Mine-Drainage on the Macroinvertebrates of Trout Creek, Colorado," Colorado State University Natural Resource Ecology Lahoratory, Port Collins, and Montana State University Fisheries Bioassay Laboratory. Bozeman, Internal project Report No. 5, pp. 179-195 (1976).

Warner, R.W.. "Distribution of Biota in a stream Polluted by Acid Mine-Drainage," Ohio Journal of Science, 71:202-215 (1971).

Harnick, S.L. and H.L. Bell, "Acute Toxicity of Some Heavy Metals to Different Species of Aquatic Insects," Journal of the Hater pollution Control Pederation, 41(2):280-284 (1969). 
Water Pollution Fesearcb Iaboratory, Stevenage, England, "Fish and Water Quality Criteria," Notes on Nater pollution, No. 65 (June 1974).

Wayland, J.R., et al.. "Heary Metals in Estuarine Benthic Organisms and Sediments: Data and Model," Sandia Laboratories, Albuquerque, N.M., SAND 75-0518 (1975) . (Available from NTIS)

Meaver, R.H. and H.D. Nash, "Effects of Strip Mining on the Microbiology of a strean Free from Domestic pollution." Proceedings of the 2 nd Symposium on Coal Mine Drainage Research, Ohio River valley water Sanitation Commission. Cincinnati. pp. 80-97 (1968).

need, C.E. and C.W. Rutschky, III., "Benthic Macroinvertebrate Conunity Structure in a Stream Receiving Acid Mine-Drainage," proceedings of the pennsylvania Academy of Science, $46: 41-47$ (1972).

Weis, J.S. and P. Weis, "Effects of Heary Metals on Development of the Killfish. Eundulus heteroclitus." Journal of Fish Biology. $11(1): 49-54(1977)$.

Weiss, C.M. and J.C. Bolts, "Factors Affecting the Respopse of Fish to Toxic Materials," Sewage and Industrial wastes. $29: 810-818$ (1957).

Heiss, C.M., T.W. Yocum, and J.E. Minoque, "Further Characterization of the hater Quality of the New Hope and Lower Haw Rivers Including Benthic Macroinvertebrate Diversity and Trace Metal Analysis," North Carolina oniversity Department of Fnvironmental. Science, Chapel Hill, 200 pp. (Nov. 1972). (NTIS $\mathrm{PB}-217883 / 81$

Wel1s, P.G., "A Selected Bibliography on Rainbow Trout (sal gaiㅛ므통 Richardson) with Particular Reference to studies with Aguatic Toxicants," Report No. EES-3-AR-77-1. Enviropmental Protection Service pepartment, Fisheries and Environment, Halifax, Nova Scotia, Canada (1977).

Wentsel, R., et al.. "Sublethal Effects of Heary Metal

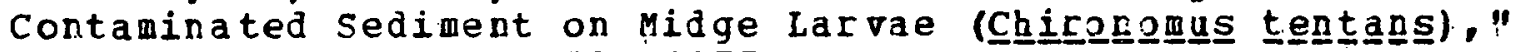
Hydrobiologia, $56(2): 153$ (1977).

Wentz, D.A.. "Effect of Mine Drainage on the Quality of streams in Colorado, 1971-1972," Colorado Water Conservation Board Water Resources Circular No. 21, 117 pp. (1974).

Wentz, D.A., "Stream Quality in Felation to Mine Drainage in Colorado," Hater hesource problews Related to Mining. Amarican Water Resources Association, Proceeding No..1R, Urbana, Ill. (June 1974). 
Whitley, I.M., et al., "Ecological Consequences of Acidic and Heavy Metal Discharges from Sudbury smelters." Canadian Mineralogist, 14:47 (1976).

Whitley, L.S. and R.A. Sikora, "Effect of Three common pollutants on the Respiration Rate of Tubificid worms," Journal of the water pollution Control Federation, Part 2; pp. R57-R56 (197n).

Whitton, B.A., "Toxicity of Heavy Metals to Freshwater Algae: A Review," Phykos, $9(2): 116-125$ (1970).

Whitton, B.A.. "Toxicity of zinc, Copper, and Lead to Chlorophyta from plowing Waters," Archiv fuer Mikrobiologie, 72:353-360 $(1970)$.

Wier, P.A. and C.H.:Hine, "Effects of Various Metals on Behavior of Conditioned Goldfish," Archives of Environmental Health, $20(1): 45-51$ (1970).

Wildish, D.J.. W.G. Carson, and W.V. Carson, "The Effect of Humic

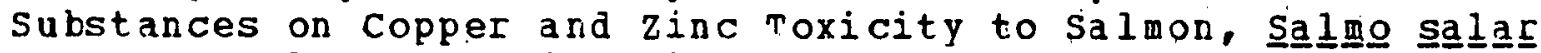
L.." Journal of the Fisheries Research Board of Canada, MS Report. $1160,8 \cdot \mathrm{pp}$. (1971).

Williams, L.G..J.C. Joyce, and J.T. Monk, JI., "Stream Velocity Effects on the Heary Metal Concentrations," Journal of the American Hater Works Association, 65(4):275-279 (1973).

Winkler, L.R. and L. Chi, "Enzymatic Defenses of Certain Snails Against Metal Ions," Veliger, 10:188-191 (1967).

Wisely, B. and B.A.P. Blick, "Mortality of Marine Invertehrate Larvae in Mercury, Copper, and zinc Solutions," Australian Journal of Marine and Freshwater Research, 18(1):63-72 (1967).

nixson, B.G., et al., "An Interdisciplinary Investigation of Environdental pollution by Lead and other Heavy Metals from Industrial Development in the New Lead Belt of Southeastern Missouri," Interim Progress Report for the period of June, 1971 to May, 1972, Submitted to the National Science Foundation, RANN (Research Applied to National Needs) Iead study Program, Vols. I and II (1972).

Wolfe, D.A., et al., "The Flux of Mn. Fe, znd zn in an Estuarine Ecosystem," proceedings of the symposium on Radioactive Contamination of the Marine Environmert, International atomic Fnerqy. Agency, Seattle, Washington, 159 pp. (1973) .

Wolfe, G.R.. "A Survey of Aquatic Insects in an Acid Coal Strip Mine Pond in Tuscarawas County, Ohio," Kent state University Research Report, Kent, Ohio, 9 pp. (1969). 
Wolfe, R.S., "Microbial Concentration of Iron and Manganese in water with Iow Concentrations of These Elements." Journal of the American haterworks Association, 52:1335 (1960).

Nood, J.M., "Metabolic Cycles for Toxic Elements in the Environment: A Study of Kinetics and Mechanism," In: Heavy Metals in the Aquatic Environment, Proceedings of a symposium at vanderbilt University, Dec, 4-7, 1973, Nashville, Tenn. (1973).

Wood, J.M.. "Metabolic Cycles for Toxic Elements in Aqueous Systems," Fevue Irternationale d'oceanographie Medicale, 31/32:7-16 (1973); Biological Abstracts, 58:46415 (1974).

Wuhrmann, Ko and H. Woker, "Toxicology of Fish II. Experimental Investiqations on the Toxicity of Ammonia and cyanide," Biological Abstracts, 25:3960 (1951).

Yager, C. M. and H. H. Harry, "Uptake of Heavy Metal Ions by

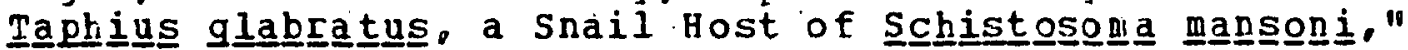
Experimental parasitology, $19: 174-182(1966)$.

Yasunaga, Y.. "The Influence of Some pollutants on the Survival of Eggs and Larvae of Two Species of Flatfish, Lịmangla yokahanamą

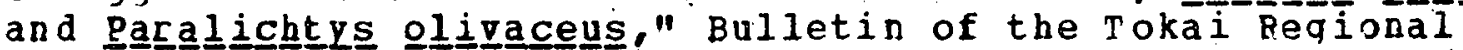

Fisheries Research Laboratory (in Japanese), (86):81-112 (1976).

Yoshii, G., N. Watabe, and Y. Ohada, "Studies on the Uptake of P32. S35, Ca45, Sr89 in the Tissues of Fish," Bulletin of the Japanese Societ. of Science and Fisheries, $22: 240$ (1955).

Young, M.L.. "Transfer of $65 \mathrm{zn}$ and $59 \mathrm{Fe}$ Along Two Marine Food Chains," Ph.D. thesis, University of East Anglia, Noruich, England (1974).

Young, R.G. and D.J. Lisk, "Effect of Copper and Silver Ions on A lgae," Journal of the Water Pollution Control Federation, $44(8): 1643-1647$ (1972).

zitko, v., "Structure Activity Relations and the Toxicity of Trace Elements to Aquatic Biota," proceedings of the International Joint Commission's workshop on Toxicity to Biota of Metal Forms in Natural Hater, R.W. Andrew, P.V. Hodson, and D.E. Konasewich, (eds.). Great Lakes Advisory Board, Windsor, pp.9-33 $(1976)$.

Zitko, V. and W.G. Carson, "A Mechanism of the fiffects of water Hardness on the Lethality of Heavy Metals to Fish, "Chemosphere, 5: $299-303(1976)$. 
REFERENCES FOR INDIVIDUAL PARAMETERS

\section{ACIDITY}

Appalachian Begional Comission, "Acid Mine-Drainage in A palachia," U.S. Government Printing Office, Mashington, D.C. $(1969)$.

Beamish, R.J." "Grouth and survival of white Suckers (Ca commersoni) in an acidified lake," Journal of the Fisheries Research Board of Canada, 31(1):49-54 (1974).

Beamish, R.J.. "Acidification of Lakes in Canada by Acid Precipitation and Resulting Effects of Fishes," Water, Air, and Soil Pollution, 6:501.(1976).

Beamish, R.J. and H.H. Harvay, "Acidification of the La Cloche Mountain Lakes, ontario, and Resulting Fish Mortalities," Journal of the Fisheries Research Board of Canada, 29:1131-1143 (1972).

Beamish, R.J. and J.C. VanLoon, "Precipitation loading of Acid and Heavy Metals to a Small Acid Lake Near Sudbury. Ontario," Journal of the Fisheries Research Board of Canada, 34:649-658 (1977).

Beamish, E.J.. et al.. "Long Tern Acidification of a Lake and Resulting Effects on Fishes," Ambio, 4:98-102 (1975).

Bell. H.I. and A.V. Nebeker, "Preliminary studies on the Tolerance of Aquatic Insects to Iow pH," Journal of the kansas Entomological Society. 42:230-236 (1969).

Bible, J.L., "An Analysis of the zooplankton Community in an acid polluted Reservoir," Proceedings of the West virginia Academy of science, 44:32 (1972).

Boyer, J.F. and V.E. Gleason, "Coal and Coal Mine Drainage," Journal of the water Pollution Control Federation, $49(6): 1163-1172$ (1977).

Brezina, E.R.. F.S. Cambell, and J.R. Whitley, "Effects of Acid Mine Drainage on water quality of a Reservoir," Journal of the water Pollution Control Federation, 4:1429 (1972).

Butler. R.L.. et al., "Fish and Food organisms in acid Mine aters of Pennsylvania," U.S. Envi conmental Protection Aqency Report EPA-R3-73-032, $158 \mathrm{pp}$. (1973). 
Campbell, R.S., et al.. "Water Pollution studies in Acid Strip-ine Lakes: Changes in water Quality and Community Structure Associated with Aging," Proceedings of the 1st Symposium on Mine Drainage Research, Cincinnati: Ohio River valley Water Sanitation Commission, pp. 188-198 (1965).

Carson. W.G.. "Avoidance of Copper in the presence of Humic Acid by Juvenile Atlantic Salmon," Fisheries Research Board of Canada uS Report No. 1237。 9 pp. (1973).

Carson, W.G. and H.V. Carson, "Toxicity of Copper and zinc to Juvenile Salmon in the Presence of Humic Acid and liqnosulfates," Fisheries Research Board of Canada MS Report No. 1181, 5 pp. $(1972)$.

Chapuan, G." "Effect of Heavy Metals on Fish," oregon state University Water Resources Research Report No. SEMN-WR-D16.73, pp. 141-162 (Jan. 1973).

Collett, Mo.g "Toxicity of Acids to Ciliate infusoria," Journal of Experimental zoology, 29:443-4.73 (1919).

Cook, R.H. and R.P. Cote, "Influence of Humic Acids on Toxicity of Copper and zinc to Jurenile Atlantic salmon as Derived from the Toxic onit concept, "Canadian Environmental protection Service, MS Report No. 72-2, 27 pp. (1972).

Cooke, H.B., "Our Mouldy Earth. A Study in the Fungi of our Environment with Emphasis on Water." Eobert A. Taft water Research Center Advanced Haste Treatment Research Laboratory, Cincinnati, Ohio (1970). (NTIS PB-217074)

Cooper, E.L. and C.C. Wagner, "Effects of Acid Mine Drainage on Pish Population," Fish and Food organisms in lcid Mine waters of Pennsylvania, U.S. Environmental Protection Agency Report EEA-R3-73-032, PP. 73-124 (1973).

Crajg. G.K. and W.F. Baksi, "Effects of Depressed pH on Flagfish Reproduction, Growth, and Survival," Water Research, 11:621 (1977).

Czensky, R., "Hydrocyanic Acid, Its Occurrence, netection, and Fffect in Streams," Hater Pollution Abstracts, 25(4):26 (1952).

Daye, P.G. and E.T. Garside, "Histopathologic Changes in Surficial Tissues of Brook Trout, salvelinus fonting (Mitchill). Exposed to Acute and Chronic Levels of pH," Canadian Journal of Zoology . 54:214C-2155 (1976).

Daye, P.G. and E.T. Garside, "Lower Lethal Levels of pH for

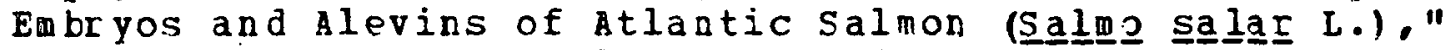
Canadian Journal of Zoology, 55:1504 (1977). 
Diehl. W. T." "A Comparative study of Plankton Respiration in an Acid Polluted Lake and Acid Free Embayments." Proceedings of the vest Virginia Academy of Science, Biology section, 44 (1):24-32 (1972).

Dively, J.L., "Blood, Lipid, protein, and Carbohydrate Changes in Brook Trout (Salvelinus fontinalis of Acidity." Ph.D. thesis, Pennsylvania state University, Joiversity Park (1972).

Dively. J.L., et a1., "Blood P C2, P CO2, and pH Changes in Brook Trout (Salyelinus fontinalis) Exposed to sublethal Levels of acidity." Comparative Biochemistry and Physiology, 57:347 (1977).

Doudoroff, P.. G. Luduc, and C.R. Schneider, "Acute Toxicity to Fish of Solutions Containing Complex Metal cyanides, in Relation to Concentrations of Molecular Hydrocyanic acid," Transactions of the American Fisheries Societv, $95(1): 6-22$ (1966).

Dunson, W.A. and R. Martin, "Survival of Brook Trout in a Bog-Derived Acidity Gradient;" Ecology, 54:1370-1376 (1973).

Dyk, V.. "Ability of Pish to Resist Fluctuations of pH Values and to Recover from Damage by Aciaified Mater," Water Pollution Abstracts, Vol. 17 (1940).

Edminster, J.0. and J.W. Gray, "Toxicity Threshold for Three Chlorides and Three Acids to the Fry of the whitefish (Coregenus

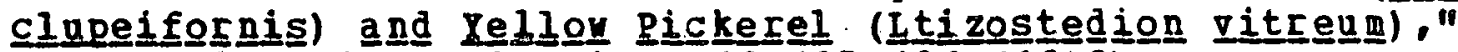
Progressive Fish-culturist, 10:105-106 (1948).

Falk, D.L. and M.A. Dunson, "The Effects of Season and Acute Sublethal Exposure on Survival Times of Brook Trout at Low pH," Water Research, 11:143 (1977).

Fowler, D.B., "Fecundity of the Brown Bullhead. Ictala nebulosus (Le Suer), in a Mine Acid Polluted River," Thesis, ilest Virginia oniversity. Morqantown (1975).

Foy, C.D. and G.C. Gerloff, "Response of chlogorella pyrenoidosa to A luminum and Low pH," Journal of Phycology, 8(3):268-271 (Sept. 1972).

German. M.J., "Effects of Acid Mine wastes on the Chemistry and Ecology of lakes in the Manitouwadge Chain. District of Thunder Bay," Ontario water Research Commission, 26 pp. (1972).

Gosner, K.I. and I.H. Black, "Effects of Acidity on the Development and Hatching of New Jersey Erogs," Ecology. $38: 256-262$ (1957). 
Greenshields. J., "Aloal Flora of Acid Mine water Impoundments in Tuscarawas County, Ohio with Special peference to the Bacillariophyta," M.S. thesis. Kent state oniversity, Kent, Obio, 120 pp. (1973).

Grice, G.D.. P.H. Hiebe, and E. Hoagland, "Acid-Iron Haste as a Factor Affecting the Distribution and Abundance of Zooplankton in the New york Bight I. Laboratory studies on the Effects of Acid waste on Copepods," Bstuarine coastal Marine Science, 1(1):45-50 (1973).

Harp. G.L. and R.S. Campbell, "The Distribution of Tendipes plumosus (Linne, ) in Mineral acid Water," Limnology and oceanography, 12:260-263 (1967).

Harrison, A.D.. "Effects of Sulphuric Acid Pollution on the Biology of streams in the Transvaal, South Africa," verhandlungen Internationale Vereinigung $f u r$ Theoretische und Angewandte Limologie, 13:605-610 (1958).

Harvey, H.H., "Fish Populations in a Large Group of Acid Stressed Lakes," Verhandlungen Internationale Vereinigung fur theoretische und Angewandte Limnologie, 19:2406 (1975).

Haupt, H.." "Death of Pish Caused by Acid Mater," Water Pollution Abstracts, 6 (1933).

Henly, J.P.. "Stream Bottom Fauna: Influences of Strip Minina on the Hydrologic Environment of Parts of Beaver Creek Basin, Ky.. 1955-1066." I.S. Geological Survey Professional Paper No. 427-C, pp. $C 46-C 49(1970)$.

Herricks, E.E.. "Recovery of Stream Macrobenthic Commuities from the Effects of Acid Mine-Drainage," Presented at the $4 \mathrm{th}$ Symposium on Coal Mine-Drainage Research, Pittsburgh, pF. $370-398 \quad(1972)$.

Hill, D. and R. Bates, "Acid Mine Draingge and subsidence Health and Ecological Effects of Increased coal "ltilization," Pesource Extraction and Handing Division. Irdustrial

Environmental Research Laboratory. U.S. Environmental protection Agency (Nov, 4, 1977).

Hoehr, R.C. and D.R. Sizemore, "Acid Mine Drainzae (AMD) and Its Impact on a Small virqinia stream," Water Resources Bulletin, $13(1): 153-160$ (1977).

Huckabee, J.W., C.P. Goodyear, and R.D. Jones, "Acid Rock ir the Great Smokies: Unanticipated Impact on Aquatic Biota of Roa Construction in Regions of Sulfide Mineralization, " Transactions of the American Fisheries Society, 104(4):677-684 (1975). 
Jewel, H.B. and H.W. Brown, "Fishes of an Acid Lake," Transactions of the Ame rican Microscopical society. 43:77-84 (1924).

Johansson, N. and G. Milbrink, "Some Effects of Acidified Hater on the Early Development of Roach (Rutilus rutilius L.) and Perch (Perca El (Feb. 1976).

Johnson, D.W.. "Spawning Behavior and strain Tolerance of Brook Trout (Sa 1 yelinus fontinalis, Mitchill) in Acidified Vater," M.Sc. thesis. Cornell Jniversity, Ithaca, N. I., 100 pp. (1975).

Johnson, M.G., H.F.P. Michalski, and A.E. Christie, "Effects of Acid Hine Hastes on Phytoplankton Communities in Tro Northern Ontario Lakes," Journal of the Pisheries Research Board of Canada, 27:425-444 (1970).

Joseph, J.M., "Microbiological Study of Acid Mine Haters: Rreliminary Report," Ohio Journal of Science, 53:123 (1953).

Joseph, J.M. and D.R. Shay, "Viability of Escherichía colli in Acid Mine Haters," American Journal of Public Health, 42:795 (1952).

Katz. M., "Biological and Ecological Effects of Acid Mine Drainage with Particular Eaphasis to the Haters of the Appalachian Region." Impact of uine Drainage on Recreation and Stream Ecology, Appendix F, Hashington, D.C., Appalachian Regional Commission (June 1969).

Kimel, M.G. and D.C. Hales, "Acute Toxicity of Low pH to Aquatic Insects," Fish Food organisms in acid Mine Haters of Pennsylvania, D.S. Environmental Protection Agency Report EPA-R3-73-032, pp. 25-158 (1973).

Koryak, M.. M. A. Shapiro, and J.L. Sykora, "Riffle Zoobenthos in Streams Receiving Acid घine Drainage," Water Research, $6(10): 1239-1247$ (1972).

Ruain, M. "Effects of Temperature on Development and Survival of Rainbow Trout, Sal mo gairdneri, in Acid Waters," Journal of the Fisheries Research Board of Canada, 32:493-497 (1975).

I.ackey, J.B., "Aquatic Life in Haters Polluted by Acid Mine Maste," Public Health Reports, 54:740-746 (1939).

Leivestad, H. and I.P. Muniz. "Fish Kill at Low pH in a Norvegian River," Nature, 259:391 (1976).

Iind, O.T. and R.S. Campbell, "Community Metabolism in Acid and Akaline Strip-uine Lakes," Transactions of the american

Fisheries Society. 99 (3):577-582 (July 1970). 
Lloyd, R. "Water Quality criteria for European Freshwater Fish. Report on Extreme pH Values and Inland Fisheries," European. Inland Fisheries Advisory Commission Technical Paper No. $4^{\circ}$ (1968).

Lloyd, R. and D.H.M. Jordan, "Some Factors Affecting the Resistance of Rainbow Trout (Salngo gairdneri Richardson) to Acid Waters," International Journal of Air and Water Pollution, $8: 393-40.3(1964)$.

Mahdi. M.A., "Studies of Factors Affectinq Survival of Nile Fish in the sudan. I. The Effect of Hydrogen Ion concentration," varine Bioloqy, $18(2): 89-92$ (1973).

Menendez, R." "Chronic Effects of fieduced $\mathrm{pH}$ on Brook Trout

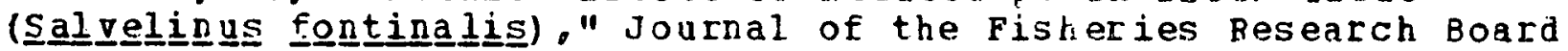
of Canada, 33:118-123 (1976).

Mierle, G. and P.M. Stokes, "Heavy Metal Tolerance and Metal Accumulation by Planktonic alqae," Trace subsiances in Environmental Health - $X$, University of Missouri, Columbia, 113 (1976).

Milbrink, G. and N. Joharsson, "Some Effects of Acidification on

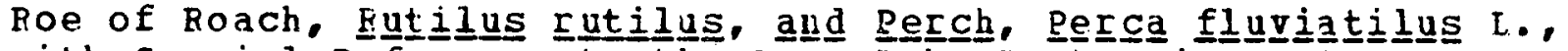
with Special Reference to the Avaa lakesystem in Eastern

sweden," Institute of Freshwater Fesearch,. Drottningholi, 54:52 $(1975)$.

Moulton, E. O.. "Acid Mine-Drainạe problem in Ohio," Ohio state University. Engineering Experimental Station Bulletin No. 166 (1957) .

Mount, D.I., "Chronic Effect of Low pH on Fathead Minnow Survival, Growth, and keproduction," Water Research, 7(7):987-993 (1973).

Nichols, L.E. and F.J. Bulow. "Effects of Acid Mine Drainaqe on the Stream Ecosystem of the East Fork of the Obey River, Tenn.." Tennessee Academy of Science Journal, 48:30-39 (1973).

Office of Water Research and Technology, "Acid Mine Hater, A Bibliographv," Report No. WRSIC 75-202, U.s. Department of the Interior, Washington, D.C., $564 \mathrm{pF}$. (1975). (NTIS PB-239 523)

Orciari, R.D. and H.D. Hummon, "A Comparison of Benthic oligochaete populations in acid and Neutral Ientic Environments in Southwestern Ohio." Ohio Journal of Science, 75(1):44-49 (1975).

Overrein. L.N.. "A Presentation of the Norwegian Profect 'Acid Precipitation-Effects on Forest and Fish," Water, Air, and soil pollution, 6:167-172 (1976)。 
Parsons, J.D., "Effects of Acid strip Mine Pollution on the Ecology of a central Missouri stream," Ph.D. thesis, University of Missouri, Columbia (1956).

Parsons, J.D., "Effects of Acid Strip Mine Effluent on the Ecology of a Stream," Archives of Hydrobiology, 65:25-50 (1968).

Parsons, J.W.. "Acid Coal Mine Pollution and Related Subjects," Journal of the Tennessee Academy of Science, 28:160 (1953).

Pegg, W.J. and C.R. Jenkins, "Physiological Effects of Sublethal Levels of Acid Hater on Fish." Hest Virginia University, Water Research Institute, Morgantown (1976). (NTIS PB-253 958)

Phillips, A.M., Jr.. "Reduction of the Toxicity of Copper Sulphate to Pour species of Trout by the Use of Sodium Chloride and Acetic Acid," Cornell University Abstracts of Theses, 1939. Ithaca, N.Y.. pp. 297-299 (1940).

Ragsdale, E.I. and F.J. Bulow, "Possible Effect of Acid Mine Drainage on the water Quality and Fish population of Dale Hollow Reservoir. Tennessee and Kentucky." Journal of the Tennessee Acadeng of science, 50(3):91-95 (1975).

Rashid, H.A. and J. Leonard, "Modifications in the Solubility and Precipitation Behavior of Various letals as a Result of Their Interaction with sedinentary Humic Acid," Chemical Geology, 11:89-97 (1973).

Richards, J.N., "Studies of Phytoplankton and soil Algae of Two Acid Strip Mine Impoundments in Tuscarawas County. Ohio," M.A. thesis, Kent State University; Kent, Ohio, 56 pp. (1974).

Roback, S.S. and J.R. Richardson, "effects of Acid Mine Drainage on Aquatic Insects," Proceedings of the Academy of Natural Sciences, Philadelphia, 121:81 (1969).

Robinson, G.D.. et al.. "Differences in Low pH Tolerance Among strains of Brook Trout (Salvelinus fontinalis Biology, 8:5-17 (1976).

Ruby. S.M.. et al., "Effects of Depressed pH on Oogenesis in

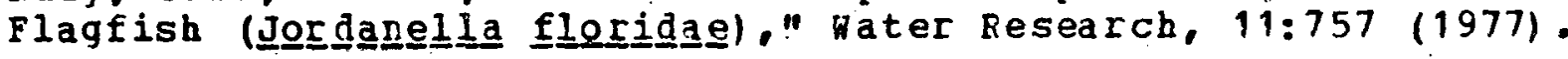

Buthren, J.A. and J.Cairns, Jr.: "Response of Presh-Water protozoan Artificial Communities to Metals," Journal of Protozoology. 20(1):127-135 (1973).

Sakurayama, H.. "studies on selenium Poisoning 7. Bxperimental studies on Rearing of Fishes, Shells and Duckweed in selenious Acid Solution," Shikoku acta medica, 16:122-127 (1960). 
Schmitt, J.B., "Breeding of Anophelia crucians in Highly Acil Haters in Abandoned Clay Pits in Middlesex County, New Jersey," Water Pollution Abstracts, 17 (June 1944).

Schofield, C.L.. "Acid Precipitation Effects on Fish," Ambio, $5: 228(1976)$.

Shearer, R.E. and H.A. Everson. "Study of Bacteriophage in Controliing Acid Mine 月ater," Symposium on Acid Mine Drainage Research, Rittskurgh, pp. 23-34 (1965).

Sheridan, J.R.. "Pish Population: Influences of Strip Mining on the Hydrobiologic Environment of Parts of Beaver Creek Basin, Ky., 1955-1966," 0.S. Geol sgical Survey Professional Paper No. $427-\mathrm{C}, \mathrm{pp} . \mathrm{C} 5)-\mathrm{C} 53(1970)$.

Sizemore, D.R.. "PfEects of Acid Mine Drainage on Chestnut Creek, Virginia," M. S. thesis, Virginia Polytechnic Institute and state University, Blacksburg, 96 pp. (1973).

Smith, R.W. and D.G. Frey, "Acid Mine Pollution Effects on Lake Bioloqy," D.S. Environmental Protection Aqency, water Pollution Control Research Series Report EPA-18050-BBC-12/71, $132 \mathrm{pp}$. (1971).

Sparks, R.E.. J. Cairns, Jr., and F.B. Cross, "Some Effects of a Neutral Mixture of Calcium oxide and Sulfuric Acid on Channel

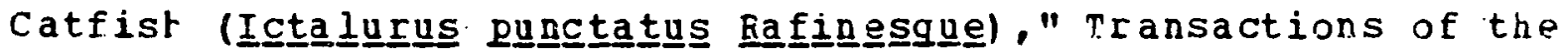

Zitko, V., W.V. Carson, and W.G. Carson, "prediction of Incipient Jethal Levels of copper to Juvenile Atlantic salmon in the Presence of Humic Acid by Cupric Electrode," Bulletin of Environmental Contamination ard Toxicology, 10(6):265-271 (1973).

\section{ALKALINITY}

Brkovic-popovic, I. and . Popovic, "fffects of Heavy Metals on Survival and Respiration Rate of Tubificid Norms: Part I Effects on Survival," Environmental Pollution, 13:65-72 (1977).

Brown. V.M., "The Calculation of the Acute roxicity of Mixtures of Poison to Rainbor Trout," Hater Research, 2(10):723-733 $(1968)$.

Chapman, G.. "Effect of Heary Metals on Fish," oregon State University water Resources Research Eeport No. SEMN-WR-D16.73, pp. 141-162 (Jan. 1973). 
Daye, P.G。 and E.T. Garside, "Histopathologic Changes in Surficial Tissues of Brook Trout, Salyelinus fontinalis (aitchill). Exposed to Acute and chronic Levels of pH." Canadian Iotenal of 20010gY, 54:2140-2155 (1976).

Breeman. R.A. end H.H. Everhart, Moxicity of aluminum Hydroxide Complexes in feutral and Basic Hedia to Rainbow Trout " Trassactions of the Arerican Fisberies society, $100(4): 644-658$ $(9971)=$

Huckabee, J.H. C. P. Goodjear, and R.D. Jones, "Acid Rock in the Great Smokies: Unanticipared Impact on Aquatic Biota of Boad Construction in Regions of Sulfide Hineralization " Transactions of the American Fisheries Society, 104(4):677-684 (1975).

Kigal, H.G. and D.C. Hales, "Acute Toxicity of Lou pH to aquatic Insects," Fish Food organisns in Acid Mine waters of Pennsylvania, 0.S. Environgental protection Agency Report EPA-R3-73-032, DP. $125-158(1973)$.

Koelling, J.J.o "Relationship of Trace Elements to Algae Growth," Ph.D. thesis. Washington State University, Pullman (1971).

lind, O.T. and R.S. Campbell, "Community Metaboliso in Acid and Alkaline Strip-tine Lakes," Transactions of the American Fisheries Society, 9,9(3):577-582 (July 1970).

Lloyd, R. "Rater quality Criteria for European Freshuter Fish. Report on Extreme pH Values and Inland Fisheries," European Inland Fisheries Advisory Comission Technical Paper No. 4 (1968).

Mahdi, A.. "Studies of Factors Afecting Surviral of Hile Fish in the sudan. I. The Effect of Hydrogen Ion concentration," Mariae Biology. $18(2): 89-92$ (1973).

Maine Departwent of Environental Protection. "Policy Regarding the ose of Copper Compounds as Aguatic Herbicides in Maine." Report by the Division of Lakes and Biological studies, Augusta (Feb. 1976).

Bount, D.I., "Chronic Effect of Low pH on Fathead Minnow Survival, Grouth, and Reproduction," Water Research, 7(7):987-993 (1973).

Neel. J.K.g "Biotic Character as Related to Stream Mineral content," Transactions of the American Microscopical society, $92(3): 404-415$ (1973).

Pagenkopf, G.K..R.C. Russo, and R.V. Thurston, "Effect of Couplexation on Toxicity of Copper to Fishes " Journal of the Fisheries Research Board of Canada, 31:462-465 (1974). 
Singh, S.B.. S.C. Banerjee, and P.r. Chakrabarti, "preliminary observations on Besponse of Young ones of Chinese Carps to

Various Physico-Chemical Pactors of Water," Froceedinqs of the National Academy of Sciences. India, 37 (111):320-324 (1967).

Smith, E.J., "Effects of Lime Neutralized Iron Hydroxide Suspensions on Selected Species of North American Fish," Ph.D. thesis, Oniversity of Pittsiurgh, Graduate School of Public Health (1973).

Stiemke, R.E. and W.W. Eckenfelder, "Practical Method for Predicting the fffect of Common Acids and Alkalies on the Survival of Fish," Abstracts of the Sewage Norks Journal, 20:592 (1948).

Sykora, J.I., E.J. Smith, and M.A. Shapiro, "Chronic Effect of Ferric Hydroxide on Certain species of aquatic Animals," Proceedings of the 4 th Symposium on Coal line Drainage Research, Mellon Institute, Pittsburgh, p. 347 (April 26-27, 1972).

Sykora, J.L., F.J. S四ith, and M. Synak, "Effect of Iime Neutralized Iron Hydroxide Suspensions on Juvenile Brook Trout

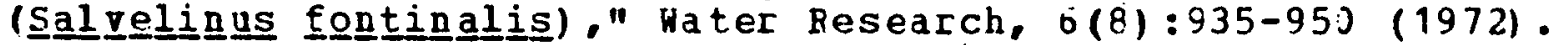

Sykora, J.L., et al.." "Some Observations on Spawning of Brook

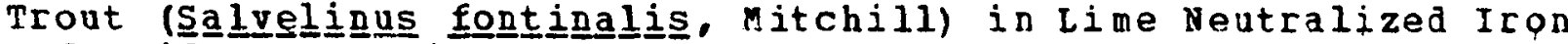
Hydroxide Suspensions," Hater Research, 9(4):451-458 (1975).

Hells. H.H." "Reactions and Fesistance of Fishes in the Natural Environment to Acidity. Alkalinity, and Neutralit.," Biological Bulletin, 29:221-257 (1915).

Went, A.E.J. and W.E. Frost, "River Liffey survey $V$. Growth of

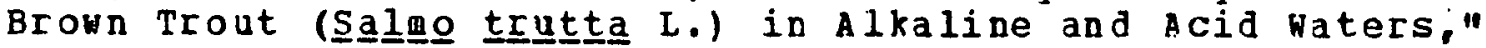
Proceedings of tbe Royal Irish Academy. Vol. 68, Section B, No. 7 . pp. $67-84$ (1942).

Young, R.T., "Resistance of Fish to Salts and Alkalinity," American Journal of Physiolody. 63:373 (1923).

\section{ALUMINUA}

Burrows, H.D., "Aquatic Aluminum: Chemistry, Toxicology, and Environmental Prevalence," CRC Critical Revieus in Environmental Control, $7(2): 167-216$ (1977) .

Calabrese, A., et al.. "Toxicity of Heavy Metals to Embryos of

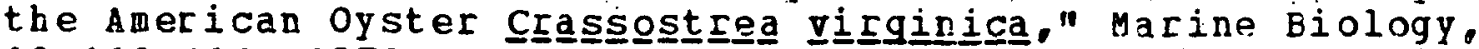
$18: 162-166$ (1973). 
Decker, C.F. and B: Menendez, "Acute Toxicity of Iron and Aluminum to Brook Trout," Proceedings of the vest Virginia Acaden of science. 46:159 (1974).

Everhart, H.H. and R.A. Freeman, "Effects of Chemical Variations in Aquatic Environments: Volume II. Toxic Effects of Aqueous Aluminum to Rainbow Trout," O.S. Environuental Protection Agency Report BPA-B3-73-0116 (1973). (NTIS PB-221344).

Poy. C.D. and G.C. Gerloff, "Response of chlorella pyrengoido dosa to A Iuninut and Low pH," Journal of Phycology, 8(3):268-271 (Sept. 15721 .

Freeman, R.A. "A Constant Flow Delivery Device for Chronic Bioassay, "Transactions of the American Pisheries Society. $100(1): 135-136$ (1971).

Ereeman, R.A., "Recovery of Rainbow Trout from Aluainu Poisoning." Transactions of the american Fisheries society. $102: 152$ (1973).

Freeman, R.A. and W.H. Everhart, "Toxicity of Aluminum Hydroxide Complexes in Neutral and Basic ledia to Rainhow Trout," Transactions of the American Fisheries society, 100(4):644-658 (1971).

Hoffer, K.. "Action of Aluminum Salts on Spirogyra and zygema," protoplasma, $49: 248$ (1958).

Mayer, F.I. and J.L. Hamelink, "Aquatic Toxicology and Hazard Evaluation," merican Society for Testing and Materials, STP 634 (1977).

Minkina, A.L., "On the Action of Iron and Aluminum on Fish," Water Pollution Abstracts, Vol. 23 (1950): Trudy Moskovskogo zooparka (in Russian), 3:23-26 (1946).

Pulley, T.E., "Affect of Aluminum Chloride in Small concentrations on Various Marine organisms," Texas Journal of Science, 2: 405-411 (1950).

Ruthren, J.A. and J. Cairns, JI," "Response of Fresh-Water Protozoan Artificial Conmuities to Metals," Journal of Protozoology, 20(1):127-135 (1973).

Salzinger, K.., et al.. "Behavior of the Goldfish as an Early Warning systen for the Presence of pollutants in Water," Journal of Environmental Systems, 3(1):27-40 (Spring 1973).

Sanborn, N.H.. "The Lethal Bffect of Certain Cheticals on Fresh nater Fish," Canning Trade, 67(49): 10-12 (1945). 
Scheier, A. and P. Kiry, "A Discussion of the effects of Certain Potential roxicants on Fish and Shellfish in the Upper Delaware Estuary," Academy of Natural Sciences of Philadelphia, Penn. (Dec. 1973). (NTIS PB-231 423)

Wallen, I.E., W.C. Greer, and R. Lasater, "Toxicity to Gagnguusia affinis of Certain pure Cheaicals in Turbid Waters," Sewage and Industrial hastes, 29 (66):595-711 (1957).

\section{AMMONI A}

Abbott, 0.J.. "The Toxicity of Amonium Molybdate to Marine Invertebrates," Marine Follution Bulletin, 8:204 (1977).

-Academy of Natural sciences, "The sensitivity of Aquatic Life to Certain Chemicals Commonly Found In Industrial Hastes," Philidelphia, Penn. (1960).

Alabaster, J.S. and D.M. Herbert, "Influence of Carbon Dioxide on the Toxicity of Ammonia," Nature 174 (4426):404 (1954).

Anderson, B.G.. "susceptirility of Salmonid Fish to poisons Under Estuarine Conditions II. Ammonium Chloride," International Journal of Air and Hater Pollution, 9:89-91 (1965).

Ea11. I.R.. "Relative Susceptibilities of Some species of Freshwater Fish to poisons I. Ammonia," water Research, 1:767-775 (1967).

Brown; V.M., "The Calculation of the Acute Toxicity of Mixtures of Poison to Rainbow Trout," water Research, 2(10):723-733 $(1968)$.

Brown, V.M.. B.A. Tiller, and D.H.M. Jordan, "Acute Toxicity to Rainbow Trout of Fluctuating Concentrations and Mixtures of Amonia, Phenol, and Zinc," Journal of Fish Biology, 1:1-9 $(1969)$.

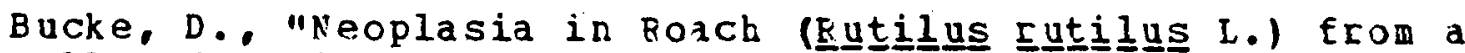
Polluted Environvent;" proqress in Experimental Tumor Research, $20: 205(1976)$.

Buikema, A.L., Jr.. D.R. Lee, and J. Cairns, Jr., "A Screening Bioassay Using Dạphniaㅡ pullex for Refinery Wastes Discharged into Freshwater," Journal of Testing and Evaluation, 4(2):119-125 (1976).

Burkhalter, D.E. and C.M. Kaya, "Effects of Rrolonged exposure to Ammonia on Fertilized Eqgs and Sac Fry of Rainhow Trout (Sa

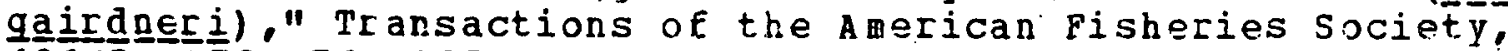
$106(5): 470-476$ (1977). 
Burroys, R.E.. "Effects of Accumulated Excretory Products on Hatchery-reared Salmonids," Bureau of sport Fisheries and Hildife Research Report 66 , 0.S. Government Printing office, Hashington, D.C. (1964).

Calari. D. and R. Marchetti. "predicted and observer Acute Toxicity of Copper and Amonia to Rainbow Trout (sa Rich.l "rater Pollution Research Proceedings, S.H. Jenkins, (od.). Bergaron, Ney Pork, pp. 569-576 (1975); Progress in Hater Technology, $7(3 / 4): 569-577$ (1.975).

Cole. A.E. "Effects of pollutional Hastes on Fish Life," Symosiug on Hydrobiology, Tniversity of Wisconsin, Madison, p. $241(1941)$.

Colt, J. and G. Tchobanoglous, "Evaluation of the short Term Toxicity of Nitrogenous Compounds to Channel Catfish, Ictalu픈 punctatús," Aguaculture, 8:209-224 (1976).

De L.G. Solbe, J.F.. "Relation Bet ween water quality and the Status of Fish Populations in Hillow. Brook," pater Treatment and Exarination, 22(1):41-61 (1973)。

Downing, K.M. and J.C. Merkens, "The Influence of Dissolved oxygen Concentration on the Toxicity of Un-ionized Ammonia to

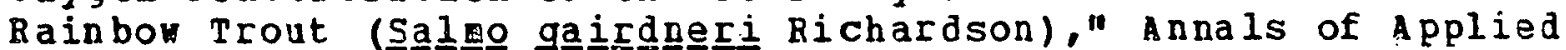
Biology, $43(2): 243-246(1955)$.

Emerson. K.. et al.. "Aqueous Amonia Equilitrium Calculations: Effect of $\mathrm{pH}$ and Teperature," Journal of the Fisheries Research Board of Canada. 32(12):2379-2383 (1975).

Epifanio, C.C. and R.F. Srna, "Toxicity of Amonia, Nitrite Ion, Hitrate Ion, and Orthophosphate to Mercenaria mercenaria and Crossostrea víxginica," Marine Biology, $33: 241-246$ (1975).

European Inland Fisheries Adisory Commission, "water Quality Criteria for European Freshwater Fish, Report on Amonia and Inland Fisheries," Water Besearch, 7(7):1011-1022 (1973).

Fitzgerald, G.P., "Are Chemicals Used in Algae control Biodegradable?" " Nater and Sewage Works, 122(5):82-85 (1975).

Flis, J., "Anatonico-Histopathological Changes Induced in Carp (Cyprinus carpio L.) by Ammonia water I. Effect of Toxic Concentrations II. Effects of Sub-Toxic concentrations," Acta Hydrobiologica, 10:205-238 (1968).

Frahn. J.P.s "Toxicity Tolerance studies otilizing Periphyton (Toxitoleranzversuche an Wassermoosen)." Gewasser und abwasser, $57 / 58: 59-66$ (1975). 
Fromm, P.o.. "Toxic Action of rater soluble pollutants. on Freshwater Fish." BPA Nater Pollution Control Research Series No: 18050DST, U.S. Government Printing Office, Washington, D.C. (1970): Michigan State University Water Pollution Control Research Series, East Lansing (1970). (NTIS PB-201 650)

Funk, H.H., "Biological Impact of Combined Hetallic and organic pollution in the Coeur DPlene-Spokane River Drainage system." Hashington State Oniversity and University of Idaho Report to OWRR, B-044 wash and B-015 IDA (1973).

Guerin-Ancey, O., "Experimental study of the Nitrogen Excretion

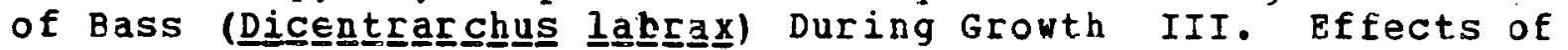
Hater Volume and Initial Amonia Concentration on the Excretion of Amonia and urea," Aguaculture (in Prench), 9:253 (1976).

Hampson, B.L., "Ammonia Concentration in Relation to Ammonia Toxicity During a Rainboy Trout Rearing Experiment in a closed Freshwater-Seawater systen," Aguaculture, 9:61-70 (1976).

Hattingh, J., "Blood Sugar as an Indicator of stress in Freshwater Fish, Iabeo capensis (Smith)," Journal of Fish Biology. 10:191-195 (1977).

Herbert, D.H.M. and D.S. Shurben, "The Toxicity to Fish of Mixtures of Poisons $I$. Salts of Amonia and Zinc," Annals of Applied Biology, 53:33-41 (1964).

Herbert, D.H.H. and D.S. Shurben. "The Susceptirility of Salmonid Fish to poisons onder Estuarine conditions II. Ammonium Chloride," International Journal of air and Nater pollution 9:89-91 (1965).

Herbert, D.W.M. and J.M. VanDyke, "The Toxicity to Fish of Mixtures of Poisons II. Copper-Ammonia and Zinc-Phenol bixtures." Annals of Applied Biology, 53:415-421 (1964).

Ito; T. "Optake of Dissolved ammoniun and Nitrate Ion by the Fry of Common Carp, Crucian Carp, and Loach from Surrounding water," Bulletin of the Freshrater Pisheries Research Laboratory, Tokyo, $26(1): 27-33$ (1976): Aquatic Sciences and Fisheries Abstracts, $7(7): 708561(1977)$.

Johnson. W.W. and H.O. Sanders. "Chemical Forest Fire Retardants: Acute Toxicity to Five Freshwater Fishes and a Scud," Technical Report No. 91, 0.S. Department of the Interior, Fish and wilalife Service, Washington, D.C. (1977).

Jude, D.J.. "Sublethal Effects of Ammonia and Cadmium on Growth of Green Sunfish," Unpublished Ph.D. thesis, Michigan State University. East Lansing. 193 pp. (1973). 
Keeney, D.R., "Fate of Nitrogen in Aquatic Ecosystems," Eutrophication Information Progran, Literature Review No. 3 , University of Wisconsin Water Resource Center, Uadison (1972). (NTIS $\mathrm{PB}-209$ 217)

Knepp, G.L. and G.P. Arkin, "Ammonia Toxicity Levels and Nitrate Tolerance of Channel Catfish," Progressive Pish-Culturist, $35(4): 221-224$ (1973).

Kurihara, T., et al.. "Studies on the Tolerance of the Guppy, Poecilia reticulata (Peters). A Natural Enemy of Mosquito Larvae, to the Septic Pollution of Water," Japanese Journal of Sanitation and Zoology, 24(2):165-174 (1973).

Lloyd, R.. "Effect of Dissolved oxygen Concentrations on the Toxicity of several poisons to the Rainbow rrout (Sallmo gai Richardson)," Journal of Experimental Biology, $38(2): 447-455$

(1961).

Lloyd, R., "Toxicity of Ammonia to Rainbow rrout (ㅁal Richardson)." Water and Waste Treatment Journal, $8: 27 \overline{8}-27 \overline{9}$ (1961).

Lloyd, R. and D.H.M. Herbert, "The Influence of Carbon Dioxide on the Toxicity of Un-ionized mmonia to Rainbow Trout (Sal gairdneri Richardson)." Journal of Experimental Biology. $48(2): 299-404(1960)$.

Lloyd, R, and L.D. Orr, "Diuretic Besponse by Rainbow Trout to sublethal concentrations of Ammonia," Hater Research, 3:335-344 (1969).

Malacea, I.. "Contributions to the Knowledge of Toxic Effects of Cyanides, Amonia, Mercury, and Arsenic on Some Fish species and on Dạphniia." Studii de Protectia di Epurarea Apelor, 7:751-792 $(19 \overline{6} \overline{6})$.

Natarajan, K. V.. "Toxicity of mmonia to Marine Diatoms," Journal of the Nater pollution Control Federation, 42(5):R184-190 (1970).

Neel. J.K.. "Biotic Character as Pelated to Stream Mineral Content," Transactions of the A merican Microscopical society, $92(3)=404-415$ (1973).

Neilson, A.H. and M. Doudoroff; "Amonia Assimilation in Blue-Green Algae," Archiv fuer aikrobiologie, 89:15-22 (1973).

Patrick, R.. "Effects of Varying Aoounts and Ratios of Nitrogen and Phosphates on Algal Blooms," proceedings of the $21 \mathrm{st}$ Industrial waste Conference, Purdue oniversity, Lafayette, Ind. (vay 3-5, 1966). 
Patrick, R., J. Cairns, Jr., and A. Scheier, "Relative Sensitivity of Diatoms, Srails, and Fish to Tuenty common Constituents of Industrial wastes," Progressive Fish-culturist, $30(3): 137-140 \quad(1968)$.

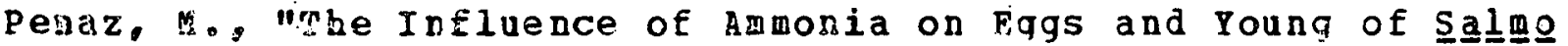
trutta ש. fario," Zoologicke listy, 14(1):47-54. (1965) Biolojical Atistracts, 48:31990 (1967).

Rabin, A.J. and A. Elmaraghy, "studies on the Toxicity of monia, Nitrate, and Their Mixtures to the Common Guppy," Ohio Water Resources Center. Columbus (1976). (HTIS PB-255 721)

Rice, S.D. and P.M. Stokes, "Hcute Toxicity of Ammonia to Several

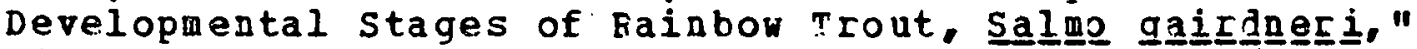
Fisheries Bulletin. 73 (1):237-211 (1975).

Robinette, H.R.. "Effect of Selected Sublethal Levels of Ammonia. on the Growth of Channel Catfish (Ictaluㄷuㅗㅡ pungctaㅡuㅡㄴ)."

Progressive ish-Culturist, $38(1): 26-29$ (1976).

Rosehool, D.P. and D.L. Richey, "Acute Toxicity of Residual Chlorine and Ammia to Some Native Illinois Fishes," Illinois State .

Selesi。 D. and P. Vamos, "Mortality Pactors of Amonia in Fish Ponds." Acta Biologica Jugoslavica: Serija D: Ekoloja, 8(1): 115-121 (1976); Aquatic Sciences and Fisheries abstracts, $7(4): 724543(1977)$.

Singer. P.C.. (ed.). "Trace Metals and Metal-organic Interactions ir Natural aters,". Ann Arbor Science Publishers, Ann Arbor, Mich.. 380 pp. (1973).

Singh, S.B.. S.C. Banerjee, and P.C. Cbakrabarti, "Preliminary observations on Response of young ones of Chinese Carps to Various Pbysico-Chemical Pactors of pater," Proceedings of the National Acadery of Sciences, India, 37 (111):320-324 (1967).

Skidmore, H. " "an Investigation of Carbon Dioxide, ammonia, and Hydrogen sulfide as Factors contributing to Fish Kills in Ice Covered Lakes." Progressive Fish-Culturist, 19:124-127 (1957).

Smart, G, "Effect of Ammonia on Gill structure of the Rainbow

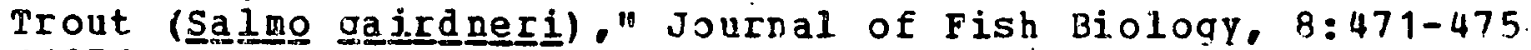
$(1976)$.

Sobsey, M.. et al.. "Kinetics of Algal Systems in waste Treatment - Ammonia-Nitrogen as a Growth Iimiting Factor and other Pertinent Topics" Sanitary Engineering Research Laboratory, university of California. Berkeley. Pinal keport, Part Ir (Sept. 1970). 
Steffens. H.. "NH3 Sensitivity of Rainbow Trout (Sa Iq음

gairdneri $)$ " Zeitschrift fuer Bienenforschung, 23(10):315-319

(1976); Aquatic sciences and Fisheries Abstracts. $7(10): 7013684$ (1977):

Toetz, D. H. " noptake and Translocation of Amonia by Freshwater Hydrophytes," Ecology. 55:199-201 (1974).

Trussel, R.P.. "The Percent Un-Ionized Ammonia in Aqueous Amonia Solutions at Different $\mathrm{pH}$ Levels and Temperatures," Journal of the Pisheries Research Board of Canada, 29(10):1505-1507 (1972).

Viner, A.B.. "Responses of a lixed Phytoplankton Population to Nutrient Enrichments of Ammonia and phosphate, and some Associated Ecological Implications," Proceedings of the Royal Society of London, Series B. 183(1073):351-370 (1970).

Water Pollution Research Laboratory. Stevenage, England, "Pish and Nater Quality Criteriz," Notes on Nater Pollution. No. 65 (June 1974).

Nillngham, T.. "Ammonia Toxicity and Its Remoral from Hastewaters," U.S. Environnental Protection Agency, Region VIII, Engineering Section, Enforcement Division (No-Date) •

Milson, R.P., R.O. Anderson, and B.A. Bloomfield, "Ammonia Toxicity. in selected Fishes," Comparative Biochemistry and Physiology. 28:107-118 (1969).

Wuhrmann, K. and $\mathrm{H}$. Hoker, "Toxicology of Fish II. Experimental Investigations on the Toxicity of Amonia and cyanide," Biological Abstracts, 25:3960 (19.51).

\section{A NTIMONY}

Aniard, J.C., "Experimental study of Acute Toxicity of Salts of Cobalt, Antimony, strontium and Silver in Crustaceans and Their Larvae and in Some Teleosts," Fevue Internationale d'Oceanographie sedicale, (in French), 43:79-95 (1976); Selected Dater Resources abstracts, 10:177-07.728, (1977).

Bringmann, G. and R. Kuhn; "The Toxic Effects of waste Water on Aguatic Bacteria, Algae, and Small crustaceans," Gesundheits-Ingenieur, 80:115 (1959).

Gringmann, G. and R. Ruhn, "Water Toxicity studies with

protozoans as Test Organisms," Gesundheits-Ingenieur, 80:239 (1959). 
Jenkins, D.W., "Flow of Toxic Metals in the Environment," International Conference on Environmental sensing and assessient. Vol. I, Las Vegas, Nev. (Sept. 14-19, 1975).

Koeliting, J.J.. "Relationship of Trace Elements to Algae Grotis, Ph.D. thesis, Washington State University, Puliman (1971)。

Tarzueld, C.H. and C. Henderson, "Toxicity of some of the tess

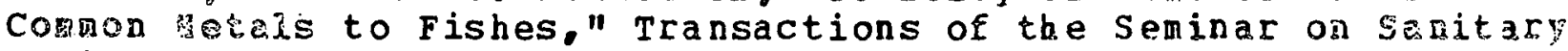
Engiaeering aspects of the Atomic Energy Industry. Robers a. Iaft Fingineering Center Report TID-7517 (1956).

Iaszello 6.0 . and C. Henderson, "Toxicity of Less Common letals to Fishes : Industrial Hastes, 5:12 (1960).

Yasunaga, Iog The Influence of Some pollutants on the Suryival.

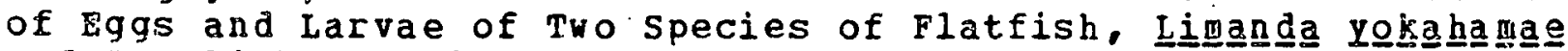
and Paralichtys olivaceus," Bulletin of the Tokai Regional

Fisheries Besearch Laboratory (in Japanese), (86):31-112 (1976).

\section{ARSENIC}

Alderdice, D.F. and J.R. Brett, "Toxicity of sodiun arsenite to Young Chum Salmon," Progress Report of the Pacific Coastal station, Journal of the Fisheries Research Board of Canada. $108: 27-29$ (1957).

Anderson, B.G.. "Toxicity Threshold of various sutstances found

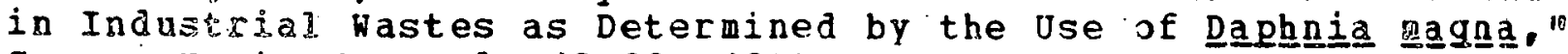
Sevaci Horks Journal, 18:32 (1944).

Andesฐon, B.G.. "Toxicity Thresholds of Various Sodiuin Salts

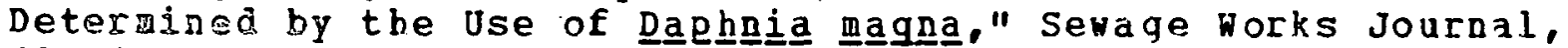
$18: 82(1946)$.

Beppu ${ }_{g}$. and $K$. Arima. "Decreased Permeability as the Mechanisn of Arsenite Resistance in pse Bact ex jology. 88(1):151-157 (1964).

Boothe, Pol. and G.A. Knauer, "Possible Importance ô Fecal Marerial in the Biological Amplification of Trace and Heavy Metals $\theta^{\prime \prime}$ isingology and Oceanography. 17(2):270-275 (1972).

Boschetti. M. and T.F. Mcloughlin. "Toxicity of sodium Arsenite to innogs, Sanitalk, $5(4): 14-18$ (1957).

Eraman, R.S. and C.C. Foreback, "Methylated Forms of Arsenic in the Engironment," Science, 182:1247-1249:(1973).

Buchanan, 日.D.., "Toxicity of Arsenic Compounds," Elsevier, Ansterdang. $155^{\circ}$ p. (1962). 
Button, D.K. and S.S. Dunker, "Biological Effects of Copper and Arsenic Pollution," Oniversity of Alaska, Fairbanks, Institute of Marine Science Report R71-8, 59 pp. (April 1971) . (NTIS PB-201 648)

Carriker, M.E., W.T. Gillespie, and P.L. Brezonick, "Boron and Arsenic Studies in Florida Naters," Oniversity of Florida water Resources Research Center, Gainesville, Publication No. 34, 100 pp. (1976).

Copenhaver, E.D.. et al.. "Arsenic in the Environment. An Annotated Bibliography," Oak Ridge National Laboratory, Tenn.. ORNL-EIS-73-16, 304 pp. (1973).

Covell, B.C.," The Effects of sodiun Arsenite and Silvex on the Plankton Populations in Farm Ponds," Transactions of the American Fisheries society, 94(4):371-377 (1965).

Cox, D.P. and M. Alexander. "Production of Trimethylarsine Gas from Various arsenic Compounds by Three sewage Fungi," Bulletin of Environmental Contamination and Toxicology,n 9 (2):84 (1973).

Dabrowski, K.R.. "The Effect of Arsenic on Embrional Development

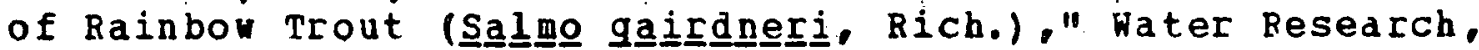
$10: 793-796(1976)$.

Gilderhus, P.A., "Some Effects of Sublethal Concentrations of Sodium Arsenite on Bluegills and the Aquatic Environment," Transactions of the American Fisheries Society, $95(3): 289-296$ $(1966)$.

Great Lakes Laboratory, "Chromiun, Cadmium, Arsenic, Selenium, Mercury, and Aguatic Life: A Brief Literature Review," State Oniversit 7 College at Buffalo, N.Y... Special Report No. 9 (1971).

Grindley, J.. "Toxicity to Rainbow. Trout and Minnows of Some Substances known to be present in Waste Water Jischarged to Rivers," Annals of Applied Biology, 33:103-112 (1946).

Inglis, A. and E.I. Davis, "fffects of water Hardness on the Toxicity of Several organic and Inorqanic Herbicides to Fish," U.S. Bureau of Sport Fisheries and Nildife Technical Paper No. 67. pp. 1-22 (1972).

Jenkins, D.W., "Plow of Toxic Metals in the Environment," International corference on Environmental Sensing and Assessment, vol. I, Las Vegas, Nev. (Sept. 14-19, 1975).

Lawrence, J.M., "Recent Investigations on the Use of Sodium arsenite as an Algacide and Its Effects on Fish Production in Ponds,". Proceedings of the 11th Annual Conference of the Southeastern Association of Game Fish Commerce, 11:281-287 (1958). 
Lueschow, L.A., "Effects of Arsenic Trioxide Used in Aquatic Hed Control Operations on Selectea espects of the Bio-Environment," M. S. thesis, University of Hsconsin, sadison (1964).

Luh, H.D. R.A. Baker, and D.E. Henley, "Arsenic Analysis and Toxicity - A Revier," Science of the Total Environmental, 2:1-12 (1973).

Iunde, G.. "The Absorption and besaboljsm of Arsenic in Fish," Fiskeridirektoratets Skrifter. Serie Taknologiske ondersoekelser. 5(12):1-16 (1973): In: The Analysis and Characterization of Trace Elenents, in Particular. Bronipa, Selenium, and Arsenic, in Marine organisms. Central Institute for Industrial Research, oslo, Nor way (1973).

Iunde, G.. "The Synthesis of Fat and water soluble afseno-oraanic Compounds in Marine and Limnetic Algae, "Acta Chemica

Scandinavica, 27:5 (1973).

Iunde, G., "Occurrence and Tranformation of Arsenic in the racine Environment," Environmental Health Perspectives, 19:47 (1977).

MCBride, B.C. and R.S. Holfe, "Biosynthesis of Dinethylarsine by Methano-Bacteriun," Biochenical Journal, 10:4312 (1971).

Halacea. I.. "Contributions to the Knowledge of Toxic Effects of Cyanides, Ammonia, Mercury, and Arsenic on some Fish species and

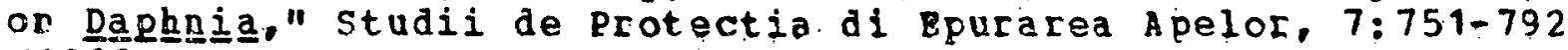
$(1966)$.

Myers, D.J., et a 1.. "Arsenic oxidation state in the presence of hicroorganisms," Environmental Letters, 5:53 (1973).

Nelson, D.A., et a 1., "Biological Effects of Heary Hetals on Juvenile Bay Scallops, Argopecten ifradians, in Short-Term Exposures," Bulletin of Environmental Containation and Toxicology, 16:3 (1976).

Penrose, W.R., "Arsenic in the Marine and Aquatic Environments: Analysis, Dccurrence, and significance," CKC critical Reviews in Euvironmental control, 4:465-48: (1974).

Pencose, W.R.. "Biosynthesis of organic Arsenic compounds in

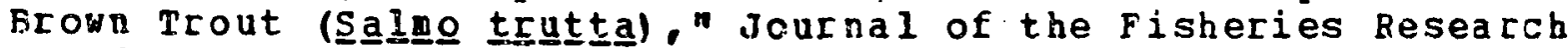
Board of Canada. $32(12): 2385-2390$ (1975).

Reay, P.F.. "The Accumulation of Arsenic from Arsenic-Rich Natural Naters by Aquatic Plants," Journal of Applied Ecoloqy, 9:2 (1972).

Ridiey, H.P., et al.. "Biomethylation of Toxic slements in the Envíconment," science, 197:329. (1977): 
Sorensen, B.M.B., "Thermal Effects on the Accumulation of Arsenic in Green Sunfish, Leponis cyanellus," Archives of Environmental contamination a nd Toxicology. 4:8-17 (1976).

Sorensen, E.M.B., "Toxicity and Accumulation of arsenic in Green Sunfish, Leponis cyanellus. Exposed to Arsenate in water," Bulletin of Environmental Contamination and Toxicology. $15(6): 756-761$ (1976).

Surber, E.H. and O.I. Mechan, "Lethal Concentrations of arsenic for Certain aguatic organisms." reansactions of the amican Fisheries Society, 61:225-239 (1931).

o.S. Department of the Interior. "Arsenic and Lead in Mater - A Bibliography," Office of Nater Resources Research Report WRSIC 71-209, 82 pp. (Sept. 1971). (NTIS PB 202 578)

Wier, P.A. and C.H. Hine, "ieffects of Various vetals on Beharior of Conditioned Goldfish," Archives of Environmental Health. $20(1): 45-51$ (1970).

Wood, J.M." "Hetabolic Cycles for Toxic Eleaénts in Aqueous Systems," Revue Internationale doceanographie Medicale. 31/32:7-16 (1973); Biological Abstracts. 58:46415 (1974).

Woolson, E.A.: et al : "Distribution and Isolation of radioactivity from $74 \mathrm{As}-$ arsenate and $14 \mathrm{C}$-Methanearsenic acid in an Aquatic Model Ecosysten;" Pesticide Biochemistry and Physiology, 6:261 (1976).

\section{BARIOM}

Biesinger, K.E. and G.M. Christensen, "Effects of Various Metals on Survival, Growth, Reproduction, and Metabolisw of Dạphnia magna," Journal of the Fisheries Research Board of Canada, 29(12): 1691-1700 (1972).

Hutchinson, T.C. "Comparative Studies of the Toxicity of Heavy Meta is to Phytoplankton and Their synergistic Interactions," Water Pollution Research in Canada, 8:68-90 (1973).

Jones, J.R.P.. "Antagonism Between Salts of the Heary and Alkaline-Earth Metals in Their Toxic action on the Tadpole of the

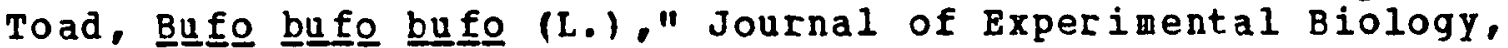
$16: 313-333(1939)$.

Jones, J.R.F., "The Relation Between the Blectrolytic Solution Pressures of the Metals and Their Toxicity to the stickleback

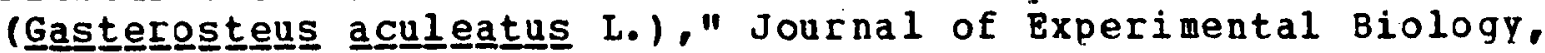
$16: 425(1939)$. 


\section{BER YLL IUM}

Dilling. H.J. and C.H. Healey, "Influence of Lead and the Metallic Ions of Copper, Zinc, Thorium, Beryllium, and Thallium on the Germination of Frogs' spawn and on the Grouth of Tadpoles," Annals of Applied Biology, 13(2):177-188 (1926): Bioloqical Abstracts, $2: 3485$ (1928).

Leclecc, E. "Self-purification of Streams and the Relationship Retween chenical and Biological Tests," Proceedinas of the 2nd Symposiun on Treatment of Waste Haters, P.C.G. Isaacs, (ed.), Perganon, Lond on, Pp. 281-316 (1960).

Pomela, C.S., "Toxicity of Beryllium," Sewage and Industrial Nastes, 25:1424-1428 (Dec. 1953).

Slonim. A.R.. "Acute Toxicity of Bervllium sulfate to the Comon Guppy," Journal of the Water Pollution Control Pederation. $45(10): 2110-2122(1973)$.

Slonim, A.B. and.F.E. Ray, "Acute Toxicity of Bervlliun Sulfate to Salamander Larvae (Ambystoma spp);" Bulletin of Environmental Contamination and Toxicology, 13(3):307-312 (1975).

Slonim, C.B. and A.P. Sionin, "Effect of water Hardness on the Tolerance of the Guppy to Berylliu日 sulfate," Bulletin of Environmental Contamination and Toxicology, 10(5):295-301 (1973).

Tarzwell, C.M. and C. Henderson, "Toxicity of Some of the Less Common Metals to Fishes," Transactions of the seminar on sanitary Engineering Aspects of the Atomic Energy Industry, Robert . Taft Engineering Conter Report TTD-7517 (1056).

\section{$B O B O N$}

Anderson, B.G.. "Toxicity Thresholds of Various Sodium Salts Determined by the Jse of Daghngia magna," Sewage Works Journal, $18: 82(1946)$.

Antia, N.J, and J.Y. Chenq. "Culture Studies on the Effects from Borate pollution on the Grouth of farine Phytoplankters," Journal of the Fisheries Besearch Board of Canada, $32(12): 2487-2494$ $(1975)$.

Birqe, W.J. and J.A. Black, "Sensitivity of Vertebrate Bnbryos to Boron Compounds," U.S. Environmental Protection Aoency. Washington, D.C., EPA-560/3-76-008 (1977). 
Carriker, N.E., w.T. Gillespie, and P.I. Brezonick, "Boron and Arsenic Studies in Florida Waters," Oniversity of Florida Mater Resources Research Center, Gainesille, Publication No, 34, 100 pp. (1976).

Sheets, M.D., "Toxicity studies of Metal-Finishing Nastes," Sewage and Industrial Nastes, 29(12):1380-1384 (1957) .

Spraque, R.R., "Ecological Significance of Boron," U.S. Borax Research Corporation, Anaheim, Calif. (1972).

Thompson, J.A.J.. et al.. "Toxicity, Optake, and Survey Studies of Boron in the Marine Environment," Water Research, 10:869 $(1976)$.

Turnbull, H., J.G. Dellann。 and R.F. Heston, "Toxicity of Various Refinery letals to Freshwater Fish." symposium on Maste Disposal in the petroleum Industry. Industrial Engineering and Chenistry, $46: 324(1954)$.

0. S. Bnvironmental Protection Aqency." Preliminary Investigation of effects on the Environment of Boron. Indium, Nickel, Selenium, Tin, Vanadium, and Their Compounds I. Boron," Report EPA

$560 / 2-75 / 005 a$ (Aug. 1975): (NTIS PB-245 984/05T)

Wallen, I.E., W.C. Greer, and P. Lasater, "Toxicity to Gạmbuaia affinis of Certain Pure Chemicals in Turbid Waters," Sewage and Industrial Hastes, 29 (66):695-711 (1957).

neeth, H.J. and G.H. Green, "An Ecological Investigation of the Accuracy of the Federal standard of Permissible Boron Levels to Water Resources," Nevada University Desert Research Station, Reno (Oct. 1974). (NTIS PB-238-298).

Burty. A.. "Action of Boric Acid on Certain Fish: Trout, Roach, Rudd," Water Pollution Abstracts; 20:1653 (1947).

\section{CADMIDM}

Ahsanullah, M.." Acute Toxicity of Cadmiun and zinc to seren Invertebrate species from Nestern Port. Victoria," Australian Journal of Marine and Freshwater Research, 27 (2):187-196 (1976).

Anderson, R.A., et al.. "Survival and Growth of Tanzetąㅗuㅗ dissingilas (Chronomidae) Exposed to Copper, Cadmium, Zinc, and Nickel," National Environmental Research Laboratory, Duluth, Minn., Quarterly Reports (1975). 
Anderson, R.V., "Cadmium, Copper, Lead, and 7inc: Tracemetal Pollutants in an Aquatic Ecosystem," NSF-SOS Grant GY-10814 Final Report, National Science Foundation, Nashinqton, D.C., 275 pp. (1973).

Arderson, R.V., "The Dccurrence of Cadmium, Copper, I,ead, and zinc in Macroinvertebrates of the Fox River, Jilinois," Unpublished M.S. thesis, Department of Biological Science, Northern Illinois University, DeKalb, 134 pp. (1975).

Anderson, R.V., "Concentration of Cadmium, Copper, Lead, and zinc in Thirty-Five Genera of Freshwater Macroinvertebrates From the Pox River, Illinois and Hisconsin," Bulletin of Environmental Contamination and Toxicology, 18(3):345-349 (1977).

Anderson, B.V., "Concentration of Cadmium, Copper, Lead and zinc in Six Species of Freshwater Clams," Bulletin of Environmental contamination and Toxicology, 18(4):492 (1977).

Anderson, R.V.. W.S. Vinikolr, and J.E. Brower, "The Distribution of $c d, C u, P b$ and $z n$ in the Biota of Two Freshwater sites with Different Trace Metal Inputs," Holarctic Ecology, 1:377-384 $(1.978)$.

Anwar, R.A., C.4. Hoppert, R.U. Byerrum, "Toxicity studies on Cadmium and Hexavalent Chromium," Water and Sewaqe Works, 107:465 $(1960)$.

Ba11, I.R.. "Toxicity of Cadmium to Rainbow Trout (Salmo

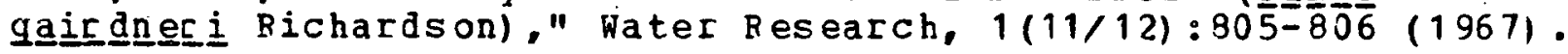

Bartlett, L., F.W. Rabe, and W.H. Funk, "Effects of Copper, Zinc and Cadmium on sele $8(3): 179-185(1974)$.

Benayoun, G., S.W. Fowler, and B. Oregioni, "Flux of Cadmium throuqh Euphausids," Marine Biology, 27:205-212 (1974).

Bengtsson, B.-E., et al., "Vertehral Damage in Minnows, phonoxịngus phoxiㅁus I.. Exposed to Cadmium," Ambio, 4 (4) 166-168 (1975).

Benoit, D.A., et al., "Toxic Effects of Cadmium on Three

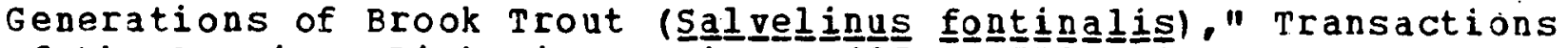
of the American Fisheries Society. $105(4): 550(1976)$.

Biesinger, K.E. and G.M. Christensen, "Effects of Various Metals

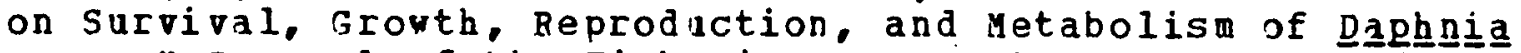
magna," Journal of the Fish 29(12): 1691-1700 (1972).

Bilinski, E. and.R.E.E. Jonas, "Fffects of Cadmium and Copper on

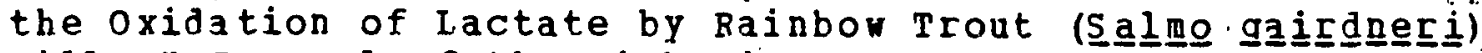
Gills," Journal of the Fisheries Besearch Board of Canada. $30(10): 1553-1558$ (oct. 1973). 
Birge, ".J. and J.J. Just, "Sensitivity of Vertebrate Embryos To Heary letals as a Criterion of Hater Quality," Kentucky Nater Resources Institute, Lexington (1973) - (NTIS PB-226-850)

Birge, W.J.. et al.. "Sensitivity of vertebrate Embryos to Heavy Metals as a criterion of Water Quality. Phase I," Kentucky Hater Resources Institute, Lexington (1974). (NTIS PB-226-850/LL)

Birge, W.J., et al., "Embryopathic Effects of Waterborne and Sediment-Accumulated Cadmium, Mercury, and zinc on Reproduction and Survival of Fish and Amphibian Populations in Kentucky," Research Report 100, water Resources Research Institute, Oniversity of Kentucky, Lexington, 28 pp. (1977);

OHRT/A-061-KY(1), U.S. Department of Commerce, NTIS, Springfield, Va. (1977).

Bondietti, E.A., et al., "Ecological Research," Ecology and Analysis of Trace contaminants, Progress Report, October 1974-December 1975. W.D. Shults and R.I. Van Hook, (eds.), Oak Ridge National Laboratory Report ORNL-NSF-BATC-22 (1976).

Boothe, P.N. and G.A. Knauer. "Possible Importance of Fecal Material in the Biological amplification of Trace and Heary Metals," Iimnology and Oceanography, 17(2):270-275 (1972).

Bovee, B.C.. "Effects of Selected Chemicals on Movement, Growth, and Survival of Certain Aquatic Animal Life, "National Technical Information service, Report No. PB-261388 (1976).

Brkovic-popovic, I. and M. Popovic, "Effects of Heavy Metals on Survival and Respiration Rate of Iubificid Norms: Part I Effects on Survival," Environmental pollution, 13:65-72 (1977).

Brkovic-popovic, I. and H. Popovic, "Effects of Heary Hetals on Survival and Respiration Rate of Tubificid Horms: Part II Effects on Respiration Rate," Environmental Pollution, 13:93-98 (1977).

Brown. V.M., "Aspects of Heavy Metals Toxicity in Fresh Naters," Proceedings of the International Joint Commission's workshop on Toxicity to Biota of Metal Porms in Natural Nater, october 7-8, 1975, Duluth, Minn.., pp. 59-75 (April 1976).

Bryan, G.W. and L.G. Hummerstone, "Adaptation of the Polychaete Nereis diversicolor to Estuarine sediment containing High Concentrations of Zinc and Cadmium,in Journal of the Marine Bioloqical Association of the United Kingdom, 53(4):839-857 $(1973)$.

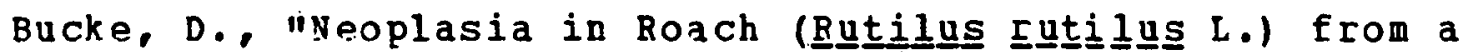
Polluted Bnvironment," Progress in Experimental Tumor Research, $20: 205(1976)$. 
Buehler, K. and H.I. Hirshfield, "Cadmium in an Aquatic F.cosystem: . Effects on Planktoric Orqanisms," In: Trace Contaminants in the Environment, Proceedings of the 2 nd Annual NSF-RANN Contaminants Conference, Asilomar, Pacific Grove, Calif., Aug. 29-31, 1974, LBL-3217, Lawrence Borkeley Laboratory. Berkeley, Calif.; pp. 283-299 (1974).

Buikema, A.L.. Jr., J. Cairns, Jr., and G.W. Sullivan,

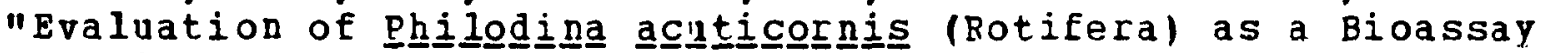
orqanism for Heavy Metals," water Resources Bulletin, $10(4): 648-661(1974)$.

Calabrese, A.. et al.. "Toxicity of Heavy Metals to Embryos of

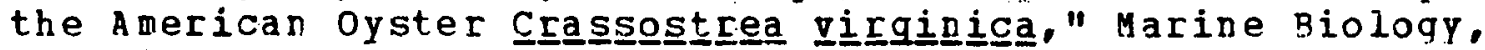
$18: 162-166$ (1973).

Calabrese, A.. et al., "Effects of Cadmium, Mercury and silver op Marine Animals," Marine Fisheries Review, 39:5 (1977).

Carter, J.W. and I.I. Cameron, "Ioxicity Bioassay of Heary Metals

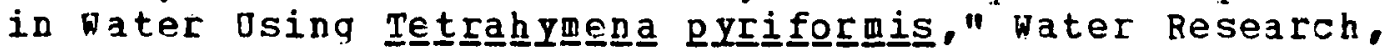
$7(7): 951-961$ (1973).

Cearley, J.E., "Toxicity and Bioconcentrations of Cadmium, Chromium and Silver in Mícㄷoterus salmoides and Lepomis macㅗ으느는," Ph.D. thesis, "Iniversity of Oklahoma, Norman, 76 pp. $(1971)$.

Cearley, J.E. and R.L. Coleman, "Cadmium Toxicity and Accumulation in Southern Naiad," Bulletin of Environmental Contamination and Toxicology, 9(2):100-101 (1973).

Cearlev, J.E. and R.L. Coleman, "Cadmium Toxicity and Biocentration in I argemouth Bass and Blueqill," Bulletin of Environmental Contamination and roxicology, 11 (2):146-151 (1974).

Chapman, G.. "Effect of Heavy Metals on Fish," Oregon State University Water Resources Research Report No. SEMN-NR-D16.73, pp. 141-162 (Jan. 1973).

Cheremisinoff, P. and Y. Habib, "Cadmium, Chromium, Lead, and Mercury - Plenary Account for water Pollution I. Occurrence, Toxicity, and Detection," Water and Sewage works, 119:73. (1972).

Christensen, G.M., "Biochemical Effects of Methylmercuric Chloride, Cadmium Chloride and Lead Nitrate on Embryos and

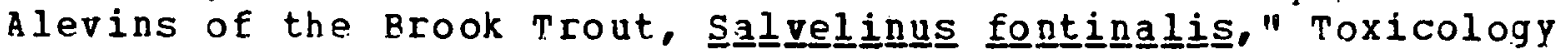
and Applied Pharmacology, $32: 191$ (1.975).

Clubb, R.W.. A.R. Gaufin, and J.L. Lords, "Acute Cadmium Toxicity Studies Upor Nine Species of. Aquatic Insects," Environmental Research, 9(3):332-341 (1975). 
Clubb, R.H., A.R. Gaufin, and J.L. Lords, "Synerqism Between Dissolved Oxygen and Caduium Toxicity in Five Species of aquatic Insects," Environmental Research, 9(3):285-289 (1975).

Collier, R.S., et al., "physiological Response of the Mud Crab,

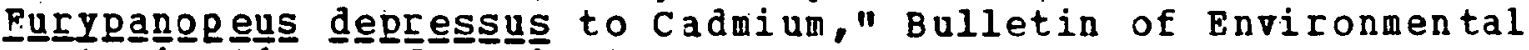
Contamination and Toxicology, 10(6):378-382 (1973).

Copenhaver, E.D.. et al. "Cadmium in the Environment: An Annotated Bibliography," Oak Ridge National Iaboratory, Tenn., ORNL-EIS-73-17, 444 pP. (1973).

Cossa. D.. "Sorption of Cadmium by a Population of the Diaton

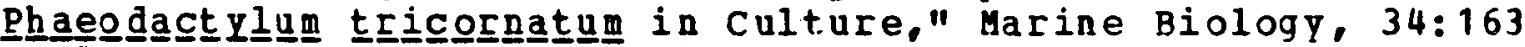
$(1976)$.

Coughtrey, P.J. and M.H. Martin, "The Uptake of Lead, Zinc, Cadmium, and Copper by the Rulmonate Mollusc, Helix a Muller, and Its Relevance to the Monitoring of Heavy Metal Contamination of the Environment," Decologia, 27:65-74 (1977).

D'Agostino, A. and C. Finney, "The Effect of Copper and Cadmi um on the Development of Tiqrígous iaponicus," In: Pollution and Physiology of Marine organisms, F.J. Vernberg and W. B. Vernberg, (eds.). Academic Press, New York, pp. 445-464 (1974).

Davies, P.H.. "Need to Establish Heavy Metal Standards on the Basis of Dissolved Metals," Proceedings of the International Joint Commission's workshop on Toxicity to Biota of Metal Forms in Natural Water, October 7-8, 1975, Duluth, Minn. (April 1976).

Decker, C.F., C.A. Hoppert, and R. J. Byerrum, "Report on Toxicity Studies of Cadmium and Chromium," Journal of the American water Works Association, 48:1279 (1956).

De I.G. Solbe, J.F., "Relation. Between Water Quality and the Status of Fish Populations in Willow Brook," Water Treatment and Examination, $22(1): 41-61$ (1973).

De I.G. Solbe, J.F. and V.A. Cooper, "Studies on Toxicity of

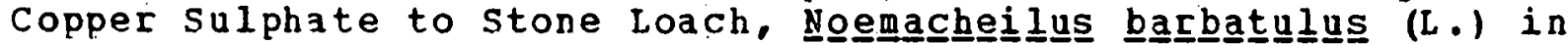
Hard Nater," Water Research, 10:523-527 (1976).

De L.G. Solbe, J.F. and V.A. Flook, "Studies on the Toxicity of

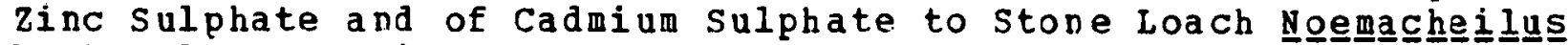
barbatulu us (L.) in Hard Nater." Journal of Fish Biology. $7(4): 631-637(1975)$.

Eaton, J.G.. "Chronic Toxicity of a Copper, Cadmium and zinc Mixture to the Fathead Minnow (Piqephales promela water Research, $7(11): 1723-1736$ (1973). 


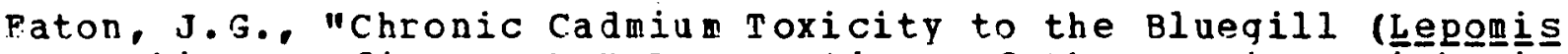
macroch Society, $103(4): 729-735$ (1974).

Eaton. J.G., "Testinony in the Matter of Proposed Toxic Pollutant Effluent Standards for Aldrin-Dieldrin, et al." "Federal vater Pollution Control Administration (307) Docket No. 1 (1974).

Eisler, R., "Cadmium Poisoning in Fundullus heteroclitús (Pisces: Cyprinodontidae) and other Marine organisms," Journal of the Fisheries Research Board of Canada, 28(9):1225-1234 (1971).

Fisler, R., "Acute Toxicities of Selected Heavy Metals to the Softshell clam, Mya arenariza," Bulletin of Environmental contamination and Toxicology, 17:137 (1977).

Eisler, R. and G.R. Gardner, "Acute Toxicology to an Estuarine Teleost of Mixtures of Cadmium, Copper, and Zinc Salts," Journal of Fish Biology, 5:131-142 (1973).

Eisler, R, and R.J. Hennekey, "Acute Toxicities of Ca2t, Cr6+, Hg2+, Ni2t and $\mathrm{Zn} 2+$ to Fistuarine Macrofauna, "Archives of Environmental Contamination and Toxicology, 6:315 (1977).

Enk, M. D. and B.J. Mathis, "Distribution of Cadmium and Lead in a Stream Ecosystem," Hydrobiologia, 52:153 (1977).

European Inland Fisheries Advisory Commission, "Water Quality Criteria for European Freshwater Fish, Report on Cadmium and Freshwater Fish," EIFAC Technical Paper No. 30, FAo, Rome (1977).

Flick, D.F., H.F. Kraybill, and J.M. Dimitroff, "Toxic Effects of Cadmium: A Review," Environtaental Research, 4:71-85 (1971).

Fowler, S.W. and G. Benayoun, "Experimental Studies on Cadmium Flux through Marine Biota," Comparative studies of Food and Environmental Contamination. International Atomic Energy Agency, vienna, pp. 159-178 (1974).

Frazier, J.M., "The Dynamics of Metals in the American Oyster,

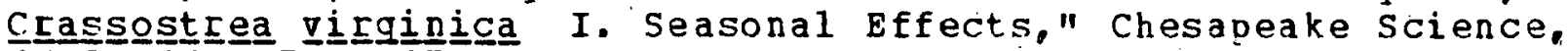
$16(3): 162-171(1975)$.

Frazier, J.M., "The Dynamics of Metals in the American Oyster.

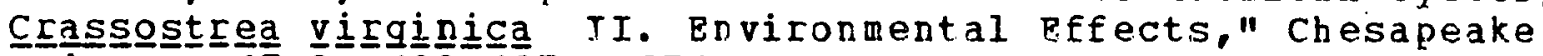
Science, $17(\overline{3}): 188-197(1976)$.

Friherg, L., M. Piscator, and G.F. Nordberg, "Cadmium in the. Environment," CRC Press, Cleveland, 166 pp. (1971): 2nd edition, 248 pp. (1974). 
Gaechter, R.. "Heavy Metal Toxicity and Synergism to Natural Phytoplankton in the Eutrophic Lake Alpnach and the Mesotrophic Horw Bay." Schweizerische Zeitschrift fur Hydroloqie, $38(2): 97$ (1976).

Gardner, G.R.. "Chemically Induced Lesions in Bstuarine or Marine Teleosts," Pathology of Pishes, H. Ribelin and G. Migaki. (eds.). Oniversity of Disconsin Press; Madison, pp. 657-693 $(1975)$.

Gardner, G.R. and P.P. Yevich, "Toxicological Effects of Cadmium

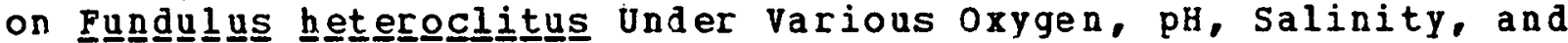
Temperature Begimes," American: Zoologist, 9(4):1096 (1969).

Gardner, G.R. and P.P. Yevich, "Histological and Hematological Responses of an Estuarine Teleost to Cadmium," Journal of the Fisheries Research Board of Canada, 27(12):2185-2196 (1970).

George, S,C. and T.L. Coombs. "The Effects of Chelating agents on the Uptake and Accumulation of Cadmium by Mytíi Bioloay. 39:261 (1977).

Giesy, J.P., et al.. "Effects of Naturally occurring Aquatic organic Fractions on Cadmium Toxicity to sịmoceph

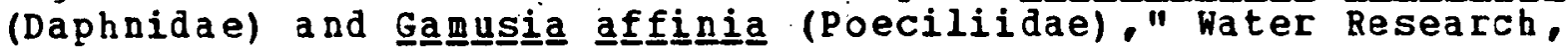
$11: 1013(1977)$.

Great Lakes Laboratory, "Chromium, Cadmium, Arsenic, Selenium, Hercury, and Aquatic Life: A Brief Literature Review," State University College at Buffalo, N.Y.. Special Report No. 9 (1971).

Hahne, H.C. and W. Kroontje, "Significance of pH and Chloride Concentration on Behavior of Heavy Metal Pollutants: Mercury (II). Cadmium (II), Zinc (II), and Lead (II), "Journal of Enviconmental Quality, 2:444-451 (1973).

Hannan, P.J. and C. Patouillet, "Effect of Mercury on algal Growth Rates," Biotechnology and Bioengineering, 4:93-101 (1972).

Helz, G.R., R.J. Huggett, and J.H. Hill, "Behavior of Mn, Fe, Cu, Zn, $c d$, and Pb Discharged from a Wastewater. Treatment Plant into an Estuarine Environment," Vater Research, 9:631-636 (1975).

Hiatt, V. and J.E. Huff, "The Environmental Impact of Cadmium: An Overview," International Journal of Environmental studies, $7: 277-285$ (1975).

Hiltibran, B.C., "Effects of Cadmium, Zinc, Manganese, and Calcium on oxygen and Phosphate Metabolism of Bluegill Liver Mitochondria," Journal of the Hater Pollution Control Federation, $43(5): 818-823$ (1971). 
Hublou, W.F.. J.W. Wood, and E.R. Jeffries, "Toxicity of Zins or Cadmium for Chinook Salmon," Oregon Fish Commission, Research Briefs, $5(1): 8-14$ (1954).

Huckabee, J.W. and B.G. Blaylock, "Transfer of Mercury and Cadmium from Terrestrial to Aquatic Ecosystems, "Metal Ions in Biological Systems, S.K. Dhar, (ed.), Plenum, New York, pp. $125-160$ (1973).

Hutchinson. T.C., "Comparative studies of the roxicity of Heary Metals to Phytoplankton and Their synergistic Interactions," Water Pollution Research in Canada, 8:68-90 (1973).

Hutchinson, T.C. and H. Czyrska, "Carmium and zinc Toxicity and Synergism to Floating Aquatic Plants," Water Pollution Research in Canada, 7:59-65 (1972).

Butchinson, T.C. and H. Czyrska, "Heavy Metal Toxicity and Synergism to Floating Aquatic Weeds," Verhandlungen Internationale Vereinigung $f$ ur Theoretische und Angewundte Limnologie, 19:2102-2111 (1975).

Jackim; E.. "Influence of Iead and Other Metals on Fish Delta-Aminolevulinate Dehydrase Activity." Journal of the Fisheries Research Board of Canada, 30(4):560-562 (1973).

Jackim, E., et al.. "Effects of Fnvironmental Factors on Radio-cadmium Uptake by Four species of Marine Bivalves," Marine Biology, 40:303 (1977).

Jenkins, D.W. "Flow of Toxic Metals in the Environment," International Conference on Environmental Sensing and Assessuent, vol. I, Las Vegas, Nev. (Sept. 14-19, 1975).

Jude, D.J.. "Sublethal Effects of Ammonia and Cadmium on Growth of Green Sunfish," Unpuhlished Ph.D. thesis, Michigan state University, East Lansing, $193 \mathrm{pp}$. (1973).

Kerfoot, H.B. and G.A. Redmann, "Permissible Levels of Heavy Metals in Secondary Effluent for ose in a Combined sewage Treatment-Marine Agriculture system II. Development of Guidelines by Method of Additions," proceedings of the Conference on wastewater use in the production of Food and Fiber, oklahoma City, Okla., pp. 79-101 (March 5-7, 1974).

Kinkade, M.L., "Behavior of Cadmium in a Simulated Aquatic Fcosystem," Ph.D. thesis, Texas Woman's oniversity, Denton $(1974)$.

Kinkade, M.L. and H.E. Erdman, "The Influence of Hardness Components (Ca2t and $M g 2+)$ in water on the Uptake and Concentration of Cadmium in a simulated Freshwater Ecosystem," Enviconmental Research, 10:308-313 (1975). 
Klass, E., D.N. Rowe, and E.J. Massaro, "Effect of Cadmium on

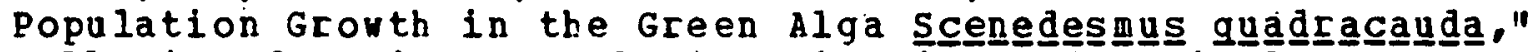
Bulletin of Environmental Contamination and Toxicology, $12(4): 442-445(1974)$.

Knauer, G.A. and J.H. Martin, "Seasonal Variations of Cadmium, Copper, Manganese, Lead, and $\mathrm{Zinc}$ in Water and Phytoplankton in Monterey Bay, California," Limnology and Oceanography, 18 (4) 597-604 (1973).

Kneip. T.J., T. Hernandez, and G. Re, "Cadmium in an Aquatic Ecosystem: Transport and Distribution," Proceedings of the 2 nd Annual NSF-RANN Trace contaminants Conference, Asilomar, Pacific Grove, Calif. Aug. 29-31, 1974, 279-282. (1974); Cited in the 13 th Annal Report, Institute of Environgental Medicine, New York University Medical Center, A. Segal, (ed.), Grant ES00260 (1976).

Kneip, T.J., G. Re, and T. Hernandez, "Cadmium in an Aquatic Ecosystem: Distribution and Effects," 8th 5ymosium on Trace Substances in Environmental Health, D. D. Hexphill, (ed.). University of Missouri, Columbia, pp. 173-177 (1974): Cited in the 13th Annual Report. Institute of Environmental Hedicine, New York University Medical Center, A. Segal, (ed.). Grant Es00260 $(1976)$.

Kumada, H.. et al.. "Acute and Chronic Toxicity, Optake and Retention of Cadmium in Freshwater organisms." Bulletin of the Freshwater Fisheries Laboratory. Tokyo, 22(2):157-165 (1972).

Lake, R.S. and V.J. Thorp, "The Gill Lamellae of the Shrimp Paratya tasmaniensis. (Atyidae: Crustacea), Normal oltrastructure and Changes with Low Levels of Cadmiun," Proceedings of the 8 th International Congress of Electron ticroscopy, 2:448 (1974).

Landner, L. and'A. Jernelov, "Cadmium in Aquatic Systems," Swedish Natural Sciences Research Council, Ecological Research Commission Bulletin, stockholm; 5:47-54 (1969).

Larsson. A. "Some Biological Effects of Cadmium on Pish," Sublethal Effects of Toxic Chemicals on Aquatic Animals, proceedings of the Swedish-Netherlands Symposium, Hageningen, Netherlands (1975).

Lu, P., et al.. "Hodel Ecospstem Studies of Iead and Cadmium and of Orban Sewage sludge Containing These Elements," Journal of Environmental Quality, 4:505 (1975) .

McCarty, L.S. and A.H. Houston, "Effects of Exposure to Sublethal Levels of Cadmium Opon Nater-Electrolyte status in Goldfish

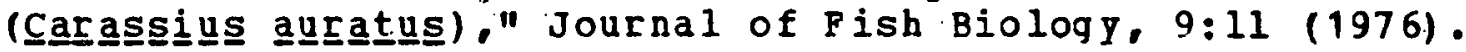


McCarty, L.S., J.A.C. Henry, and A.H. Houston, "Toxicity of

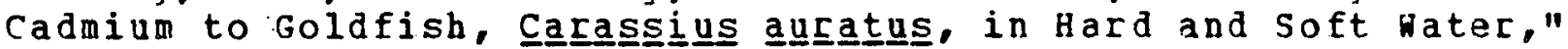
Journal of the Fisheries Besearch Board of Canada, 35(1):35-42 (1978).

MacInnes, J.R., et al., "Long-term Cadmium stress in the Cunner,

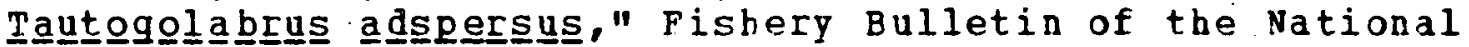

Oceanic and Atmospheric administration of the U.S., $75(1): 199$ $(1977)$.

McIntosh, A, and W. Bishop, "Distribution and Effects of Heary Metals in a Contaminated Lake," Technical Report No. 85, OWRT/A-036-IND. (1); U.S. Department of Commerce, NTIS, Springfield, Va. (1976).

Mackenzie, R.D., C.A. Hoppert, and R.D. Byercum, "Studies of Cadmium and Chromium 'Solubility and Toxicity." Journal of the American Water works Association, 49:1310 (1.957).

Majori, L. and F. Petronio. "Marine Pollution by Metals and Their Accumulation by Biological Indicators (Accumulation Pactor)." Revue Internationale d'oceanographie Medicale, 31/32:55-90 (1973).

Mand, S. and F. Broda, "Influence of Cadmium on the Growth of Chㅡ느으르ㄴㅡㅡ," Na turwissenschaften, 63 (6):295 (1976).

Mathis, B.J. and N.F. Kevern, "Distribution of Mercury, Cadinum, Lead and Thallium in a Eutrophic Lake," Hydrobiologia, $46(2-3): 207-222(1975)$.

Mayer, F.L. and.J.L. Hamelink, "Aquatic Toxicology and Hazard Evaluation," American Society for Testinq and Materials, STP 634 $(9977)$.

Middaugh, D.P., et al., "Response of Larval Fish, Lei xantbuㄷuㅗ, to Environmental Stress Following sublet.hal Cadmium Exposure," Contributions in Marine Science, 19:13 (1975).

Mills, L..."Water Quality Bioassay Usinq Selected Protozoa II. The Effects of Zinc on Population Growth of Eيqulena gra Journal of Fnvironmental Science and Health; $\frac{1}{1} \frac{1}{8}$ and 9$): 567$ (1976).

Horgan, R.P., II., et al.. "Sublethal Effects of Baltimore Harbor

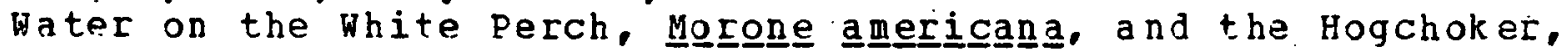

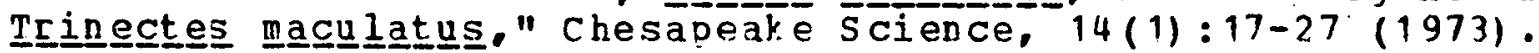

Nakani, D.V. and M.N. Korsak, "Effect of Chromium, Cadmium, and Zinc on the Rate of Photosynthesis in. Short-Term Experinents," Biologicheskie nauki, $19(9): 84$ (1976). 
Negilski, D.S. "Acute Toxicity of zinc, Cadmium and Chromium to the Marine Pishes; Yellow-Bye Mullet (Ald V.) and Smal1-Mouthed Hardyhead (Atherina Whitley)." Australian Journal of Marine and Freshwater Research, $27: 137$ (1976).

Nelson, D.A., et al., "Biological Effects of Heary Letals on

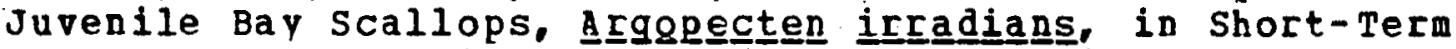
Exposures," Bulletin of Environmental Contamination and Toxicology, 16:3 (1976).

Nilsson, R.. "Aspects on the Toxicity of Cadmium and Its Compounds," Swedish Natural sciences Research Council, Ecological Research Commission Bulletin, Stockholm, 7:49 (1969).

o'Hara, J.. "Cadmium Optake by Fiddier crabs Exposed to Temperature and Salinity stress," Journal of the Pisheries Research Board of Canada 30:846-848 (1973).

O'Hara, J., "Influence of Temperature and salinity on the Toxicity of Cadmium to the Fiddler Crab, 므므 pug gil Fisheries Bulletin. 71 (1):149-153 (1973).

Overnell. J., "Inbibition of Marine Algal Photosynthesis by Heavy Metals," Marine Bioloqy, $38: 3.35$ (1976).

Parizek, J.. "Interactions of Selenium with Mercury, Cadmium, and Other Toxic Metals," Proceedings of the Symposium on Trace Element Metabolism. in Animals, Oniversity of nisconsin, Madison (1973).

Pascha 1, D.C. and . MCNamara, "Optake of Cadmium and Nickel by Salvinina," Transactions of the Illinois state Academy of Science. $68: 132(1975)$.

Pascoe, D. and P. Cran. "The Effect of Parasitism on the Toxicity of Cadmium to the Three-Spined Stickleback, Gastengos

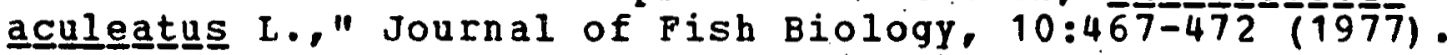

Pascoe, D. and D.L. Mattey, "Studies on Toxicity of Cadmium to 3-Spined Stickleback (Gastêrosteus aculeatuuㅗ L.)," Journal of Pish Bioloqy, 11:207 (1977).

Pavicic, J. and T. Jarvenpaa, "Cadmiun Toxicity in adults and Early Larval stages of the Mussel Mytilus galloprovincialis Lan." Comparative Studies of Food and Environmental Contamination. International Atomic Enerqy agency Report TAEA-SH-175-28 (1973).

Phillips, D.J.H., "Common ussel Mytilus eduli is as an Indicator of Pollution by Zinc, Cadmium, Lead, and Copper $I$. Effects of Environmental Variables on Uptake of Metals, " Marine Biology, $38: 59-69(1976)$. 
Pickerinq, Q.H. and M.H. Gast, "ACute and Chronic Toxicity of Cadmium to the Fathead Minnow (pimephales promelaas)," Journal of the Fisheries Research Board of Canada, 29(8):1099-1106 (1972).

Pickering, Q.H. and C. Henderson, "Acute Toxicity of Some Heavy Metals to Different Species of Warm Hater Fishes," International Journal of Air ard Water Pollution, 10:453-463 (1966).

Ray, S. and W. White, "Selected Aguatic Plants as Indicator Species for Heavy Metal Pollution," Journal of Environmental science and Health, A-11(12):717-725 (1976).

Rehvoldt, R., et al.. "Effect of Increased iemperature Upon the Acute Toxicity of Some Heavy Metal Ions, "Bulletin of Environmental Contamination and roxicology, 8(2):91-96 (1972).

Rehwoldt, R., et al... "The Acute Toxicity of Some Heary Metal Ions Toward Benthic Organisms," Bulletin of Environmental Contamination and Toxicology, 10(5):291-294 (1973).

Reish, D.J., et al.. "The Effect of Heavy Metals on Laboratory Populations of Two polychaetes with Comparisons to the Vater Quality Conditions and standards in Southern California Marine Waters," Water Research, 10:299-302 (1976).

Rosenherq, R. and J.D. Costlow, Jr.. "Synergistic Effects of Cadmium and salinity Combined with Constant and Cycling Temperatures on the Larval Development of Two Estuarine Crab species," Marine BioloqY, 33:291 (1976).

Salzinqer, K., et al.. "Behavior of the Goldfish as an Early. Varning System for the Presence of Pollutants in Water," Journal of Environmental systems, 3(1):27-40 (Sprinq 1973).

Sanqalanq. G.B. and H.C. Freeman, "Effects of Sub-Lethal Cadmium on Maturation and Testosterone and 11-Ketotestosterone Production in 므믕 in Brook Trout," Bioloqy of Reproduction, 11:429 (1974).

Sanqalang. G.B. and M.J. O'Halloran," Cadmium-induced Testicular Injury and Alterations of Androgen Synthesis in Brook Trout," Nature, $240: 470-471$ (1972).

Sangalang. G.B. and M.J. O'Halloran, "Adverse Effects of Cadmium on Brook Trout Testis and on In Vitro Testicular androgen

Synthesis," Biology of Reproduction, 9:394-403 (1973).

Sauter, S., et al., "Effects of Exposure to Heavy Metals on Selected Freshwater Fish, Toxicity of Copper, Cadmium. Chromium and Lead to Eggs and Fry of Seven Fish species," U.S. Environmental. Protection Agency Feport EPA-600/3-76-105, Duluth, vinn. 75 pp. (1976). 
Sayrs, R.L.. Jr., "Lethal and Sublethal effects of Cadmiul on Daphnia (Crustacea: Cladocera)," H.S. thesis, oniversity of Tennessee, Rnoxville, (1975).

Scheier, A, and P. Kiry, "A Discussion of the Bffects of Certain Potential Toxicants on Fish and Shellfish in the opper Delaware Estuary," Academy of Natural Sciences of Philadelphia, Penn. (Dec. 1973). (NTIS PB-231 423)

Schindler, J.E. and J.J. Alberts, "Behavior of Mercury, Chromium, and Cadmium in Aguatic systems," o.s. Environmental protection Agency, EPA-600/3-77-023, Athens, Ga. (1977).

Shaikh, Z.A. and O.J. Lucis, "Biological Differences in Cadmium and Zinc Turnover," Archives of Environmental Health, 24:410-418 (1972).

Sick, L.B. and H.I. Windom, "Effects of Environmental Levels of Mercury and Cadmium in Rates of Metal Optake and Growth Physiology of Selected Genera of Marine Phytoplankton," Proceedings of the Symposium on Mineral Cycling in Southeastern Ecosystems, Augusta, Ga., pp. 239-249 (1975).

Silverberg, B.A., "Cadmium Induced oltrastructural Changes in Mitochondria of Freshwater Green Algae," Phycologia, 15:155 (1976).

Smith, B.D., et al., "Acute Effects of Cadmium on Ictala u든 punctatus (Catfish)," Bulletin of Environmental Contamination and TOxicology, 15:271 (1976).

Spehar, R.L., "Cadmium and Zinc Toxicity to Jogrdanell (Goode and Bean): Effects on Growth, Reproduction, Survival, and Behavior," Thesis, Oniversity of Minnesota, (1974).

Spehar, R.L., "Cadmium and Zinc Toxicity to flagfish, Jorgangell floridae. "Journal of the Fisheries Research Board of Canada, 33:1939-1945 (1976).

Spehar, R.L., "Cadmiun and $\mathrm{z}$ inc Toxicity to Jorgannell o.S. Environmental Protection Agency Report EPA-600/3-76/096 (1976).

Tabata, K., "Studies on the Toxicity of Heary Metals to aquatic Animals and the Factors to Decrease the Toxicity I. On the Formation and the Toxicity of Precipitates of Heary Metals," Bulletin of Tokai Regional Pisheries Research Laboratory, $58: 203-214$ (1969).

Tabata, K., "Studies on the Toxicity of Heary Metals to Aquatic Animals and the Pactors to Decrease the Toxicity II. Antagonistic Action of Hardness components in water on the Toxicity of Heary Metal Ions," Bulletin of Tokai Regional Fisheries Research Laboratory, 58:215-232 (1969). 
Tabata, K. "Studies on the Toxicity of Heavy Metals to Aquatic Animals and the Factors to Decrease the Toxicity IV. on the Relation Between the Toxiciey of Heavy fetals and the Quality of Environmental hater," Bulletin of Tokai Regional Fisheries Research Laboratory, 58:243-253 (1969).

Taylor, D. "A Sumary of the Data on the Toxicity of various laterials to Aquatic ifife," Irperjal Cherical Industries, Vols. $p$ and 2 (1977).

Thomann, R.V., et al. "B Food Chain Rodel of Cadaium in Lake Erie," Hater Eesearch, 8:841-349 (1974).

Thormann, D.. "EEfects of Cadmium and Lead opon the Indigenous Heterotrophic Microflora in the Aqueous Environment of the Brackish Bstuary later of the Biver Veser," Veroeffentlichungen des. Instituts fuer Geeresiorschung in Bremerhaven, 15:237 (1975).

Thorp, V.J. and P.S. Lake, Toxicjty Bioassays of Cadmium on Selected Freshuter Invertebretes and the Interaction of Cadmium

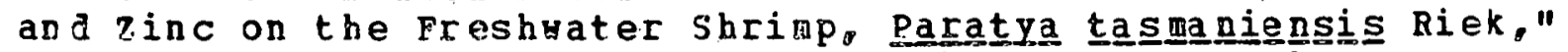
A ustralian Journal of Marine and Freshwarer Besearch. 25(1): 97-104 (1974).

Thurberg, F.P.o.A. Dawson, and R.S. Collier, "Effects of Copper and Cadmium on osmoregulation and oxyqen Consumption in $\mathrm{T}$ Ho species of Estuarine Crabs," Harine Bioloqy, 23:171-175 (1973).

Vernberg, w.B.. "Effects of sublethal Concentrations of Cadmiun on Adult palaeㅡ을 Conditions," Bulletin of Enviconmental Contamination and Toxicology, $17(1): 16-24$ (1977).

Von testernhagen, $H_{0} g H_{n}$ Rosenthal, and K.R. Sperlinq, "Combined Effects of Cadium and Salinity on Development and Survival of Herring Eggs," Helgolaender uissenschaftliche Meer esuntersuchungen, 26:416-433 (1974).

Voyer, R.A.. "Effect of Dissolved oxygen Concentration on the acute Toxicity of Cadmiun to the Mumichoq. Fundulus heteroclitus (I.), at Various Salinities," Transactions of the parican Fisheries society. $104(1): 129-134$ (1975).

Marnick, S.L. and H.L. Bell, "Acute Toxicity of Some Heavy Metals to Different Species of Aquatic Insects," Journal of the ter Pollution control Federation, 41(2):280-284 (1969).

Water Pollution Research Laboratory, Stevenaqe, England, "Fish and Water Quality Criteria," Notes on Water Pollution, No. 65 (June 1974). 
Water Resources Scientific Information Center. "Cadmium in Water - A Bibliography." office of Nater Resources Research, U.S. Department of the Interior, Report No. NRSIC-73-209, 231 pp. $(1973)$.

Wier, C.F, and M.M. Malter, "Toxicity of Cadmium in the Preshwater Snail, Physa gyrína Say," Journal of Environmental Quality, 5(4): 359-362 (1976) .

Zitko, V. and H.G. Carson, "A Mechanism of the Effects of water Hardness on the Lethality of Heavy Metals to Fish," Chemosphere, $5: 299-303(1976)$.

\section{CALCIOU}

Bodine, J.H.. "Action of Sodium, Potassium, and Calcium Chlorides on the Egg of Pundulus," Proceedings of the National Academy of Sciences of the U.S.A.. 13:698-699 (1927).

Bodine, J.H., "Action of salts on Fundulus Egg I. Action of Na,

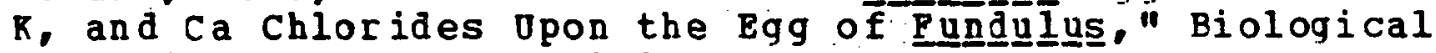
Bulletin, 54:396-404 (1928).

Bovee, E.C., "Effects of Selected Chemicals on Movement, Growth, and Survival of Certain Aquatic Animal Life, "National Technical Information service, Report No. PB-261388 (1976).

Fraha, J.P., "Toxicity Tolerance studies otilizing Periphyton (Toxitoleranzversuche an Rassermoosen)." Gewasser und abwasser, 57/58:59-66 (1975).

Hargreares, J.W. and B.A. Whitton, "Effect of pH on Tolerance of

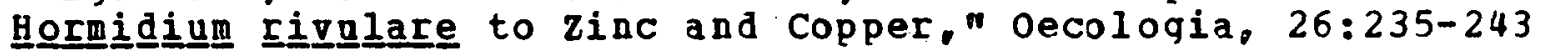
$(1976)$.

Hiltibran, R.C.. "Effects of Cadmium, Zinc, Manganese, and Calcium on Oxygen and Phosphate Metabolism of Bluegill Liver Mitochondria," Journal of the Water pollution control Federation, $43(5): 818-823 \cdot(1971)$.

Jewell, M.E.. "An Ecological study of the Preshwater sponges of Visconsin II. Influence of Calcium," EcologY, 10:11-28 (1939).

Jones, J.R.E.. "The Relative Toxicity of Salts of Lead, Zinc and Copper to the stickleback (Gasterosteus acululeatus $L$.) and the Effect of Calcium on the Toxicity of Lead and Zinc Salts," Journal of Experimental Biology, 15:394-407 (1938). 
Kinkade, M.I. and H.E. Erdman, "The Influence of Hardness Components (Ca2+ and Mq24) in Water on the Uptake and

concentration of Cadrium in a simulated Freshuater Ecosystem," Environaental Research $10: 308-313$ (1975).

Iansing. A.I., "Sone Effects of Hydrogen I on Concentration, Totaj. Salt concentration. Calciun and citrate on Longevity and Fecundity of the Rorifer," Journal of Experimental zoologys 92:195-212 (1942).

Matthiessen, D. and A.E. Brafield, "Optake and Loss of Dissolved Zinc by the stickleback Gasterosteus aculeatus L." Journal of Fish Biology. 10(3):399-410 (1977).

Mierle, G. and P.M. Stokes. "Heavy Metal Tolerance and Metal Accumulation by planktonic Algae," Trace substances in Environmental Health - X, oniversity of issouri, Columbia, 113 $(1976)$.

Neel, J.K., "Biotic Character as Related to Stream Mineral Content," Transactions of the American Microscopical Society, 92 (3): $404-415(1973)$.

Salzinger, K., et al., "Behavior of the Goldfish as an Early Harning System for the Presence of pollutants in Hater, Journal of Environmertal Systems. 3(1):27-40 (Spring 1973).

Sil1s. J.B.. "A Reviev of the Iiterature on the Dse of Lime [Ca(OH) 2, CaO, CaCO3] in Fisheries," (1974). (NTIS PB-235-449)

Smith, E.J., "Effects of Line Neutralized Iron Hydroxide Suspensions on Selected Species of North American Fish," Ph.D. thesis, University of Pittsburgh, Graduate school of Public Health (1973).

Sparks, R.E., J. Cairns, Jr., and F.B. Cross, "Some Effects of a Neutral Mixture of Calcium oxide and sulfuric Acid on Channel

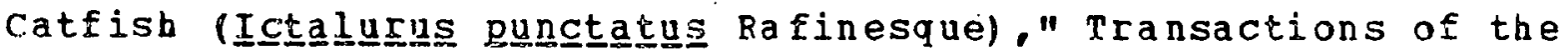
Kansas Academ of science. $72(1): 1-15$ (1969).

Sykora, J.L., E.J. Smith, and M.A. Shapiro, "Chronic Effect of Ferric Hydroxide on Certain Species of Aquatic Animals," proceedings of the is th symposium on Coal Mine Drainage Research, Mellon Institute; Pittsburqh, p. 347 (April 26-27, 1972).

Sykora, J.L., E.J. Smith, and M. Synak, "Effect of Lime Neutralized Iron Hydroxide Suspensions on Juvenile Brook Trout

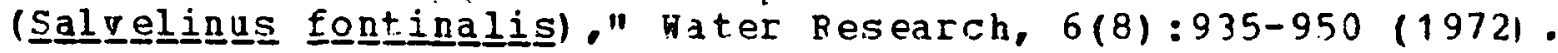

Sykora, J.L., et al.. "some observations on spawning of Brook

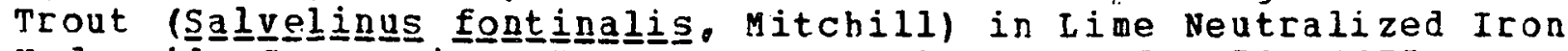
Hydroxide Suspensions," Water Research, 9(4):451-458 (1975). 
Trama, P.B., "Acute Toxicity of some common salts of sodium. Potassiun, and Calcium to the Common Bluegill (Leponis macro으른 Sciences of Philadelphia. 106:185-205 (1954).

vinikour, H.S., "Concentrations of Zinc, Copper, Cadmium, and Iead in selected Fish species of the Fox River from Locations with Varying Potential Metal Inputs," M.S. thesis, Northern Illinois University, DeKalb, 103 pp. (Dec. 1977).

Walker, J.B.. "Inorganic Micronutrient Requirements of Chlogrellila. I. Requirements for Calcium (or strontium), Copper, and Molybdenum," Archives of Biochemistry and Biophysics, 46:1-11 (1953).

Water Pollution Research Laboratory. Sterenage, England, "Fish and Nater Quality Criteria," Notes on Nater Pollution, No. 65 (June 1974).

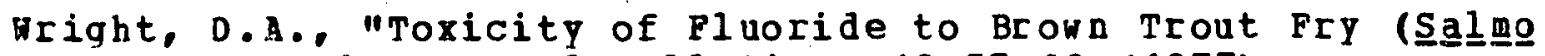
truttal)." Environmental pollution, 12:57-62 (1977).

Yoshii, G..N. Natabe, and. Y. Ohada, "studies on the Uptake of P32, S35, Ca45, Sr 89 in the Tissues of Fish," Bulletin of the Japanese Society of Science and Fisheries, 22:240 (1955).

\section{CHLOBIDE}

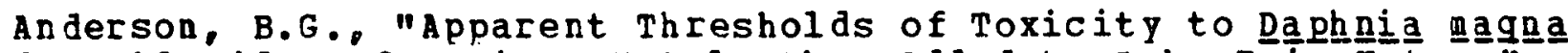
for Chlorides of Various Metals when Added to Lake Brie nater." Transactions of the American Fisheries society, 78:96-113 (1950).

Bodine, J.H., "Action of Solium, Potassium, and Calcium Chlorides on the Egg of Fundulus," Proceedings of the National Academy of Sciences of the U.S.A.. 13:698-699. (1927).

Bodine, J.H., "Action of Salts on Fundulus Egg I. Action of Na,

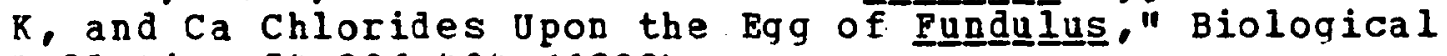
Bulletin, 54:396-404 (1928).

Edminster, J.O. and J.H. Gray, "Toxicity rhreshold for Three Chlorides and Three Acids to the Fry of the whitefish (coregonus

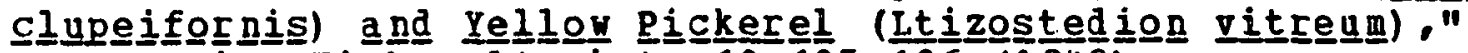

Progressive Fish-culturist, 10: 105-106 (1948).

Hahne, H.C and Hroontje, "Significance of pH and Chloride Concentration on Behavior of Heary Metal pollutants: Mercury (II), Cadmiun (II), Zinc (II), and Lead (II), "Journal of Environuental Quality. 2:444-451 (1973). 
Hahne, H.C. and $W$. Kroontje, "simultaneous effect of pH and Chloride Concentrations Upon Mercury (II) as a pollutant," Proceedings of the soil science Society of america, 37:838-84.3 (1974).

Jones, J.R.F.. "A Study of the Pelative Toxicity of Anions with

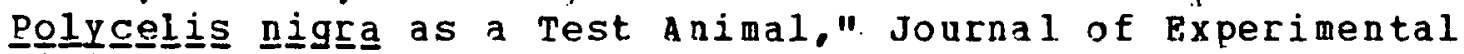
Bioloqy. 18:170-181 (1941).

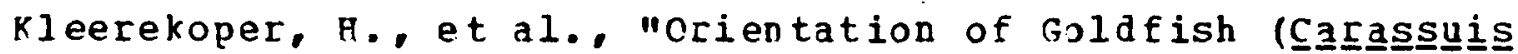
auratus Concentration of copper in an open Field, "Journal of the Fisheries Research Board of Canada, 29(1):45-54 (1972).

Roesijadi, G., et al.. "Survival and Chloride Ion Regulation of

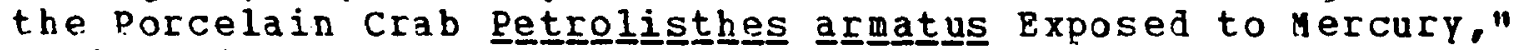
Marine Biology, 27:213-217 (1974).

\section{C.HROMIDM}

Abeqq, R., "Some Effects of Inorqanic Salts on the Blood Specific

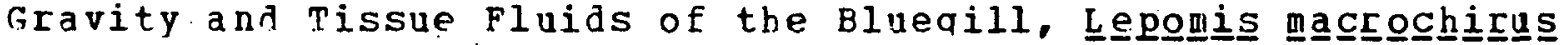
Raf.," Physiological Zoology, 23:124 (1950).

Adelman, I.R., I.I. Smith, Jr., and G.D. Siesennop, "Acute Toxicity of Sodium Chloride, Pentachlorophenol, Guthion, and

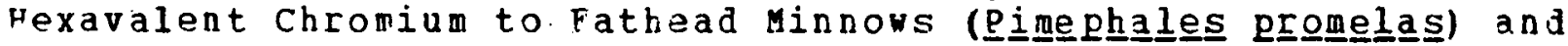

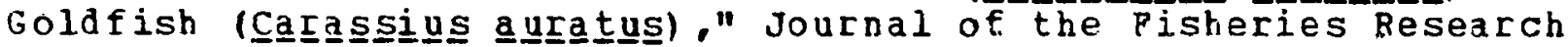
Board of Canada. $33(2): 203-208$ (1976).

Anwar, R.A.. C.A. Hoppert, R.U. Byerrum, "Toxicity studies on Cadmium and Hexavalent Chromium," Water and Sewage Works, 107:465 $(1960)$.

Associate Committe on Scientific Criteria for Environmental Quality, "Effects of Chromium in the Canadian Environment," National Research Council of Canada, NRCC No. 15017, 168 p. $(1976)$.

Aubert, M.. et al., "lutilization of a Trophodynamic Chain of a Pelaqic $T y p e$ for the study of Transfer of Metallic pollution," Revue Internationale d'oceanographie Medicale, 28:27-52 (1972).

Aubert, M.. et al.. "Use of a Neritic Trophodynamic Chain of Molluscs for the study of the Transfer of Metallic pollutants," 6th Symposium of the Internationale doceanographie Medicale, Portoroz, Yuqoslavia (Sept. 26-30, 1973); Revue Internationale d'oceanographie Medicale, 33:7-30 (1973). (NTIS CONF-7309103-1) 
Barica, J.. M.P. Stainton, and A.L. Hamilton, "Mobilization of Some Hetals in water and Animal rissue by NTA, EDTA and TPP," water Research, 7:1791-1804 (1973).

Benoit, D.A.. "Toxic Effects of Hexavalent Chromiun on Brook

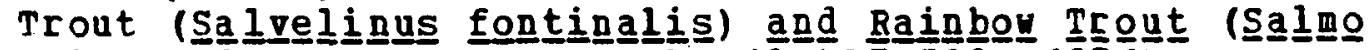
gairgnesill," Hater Research, 10:497-500 (1976).

Boothe, P.N. and G.A. Knauer, "Possible Importance of Fecal Material in the Biological aplification of Trace and Heavy Hetals," Limnology and Oceanography. 17(2):270-275 (1972).

Brinqmann, G. and R. Kuhn, "The Toxic Effects of waste pater on Aguatic Bacteria, Algae, and Small Crustaceans," Gesundheits-Ingenieur, 80:115 (1959).

Bringmann, G. and R. Kuhn, "Water Toxicity studies with Protozoans as Test orqanisms," Gesundheits-Ingenieur, 80:239 (1959).

Brkovic-Popovic, I. and M. Popovic, "Effects of Heary Metals on Survival and Respiration Rate of Tubificid Norms: Part I Effects on Survival," Environmental Pollution, 13:65-72 (1977).

Brkovic-popovic, I. and M. Popovic, "Effects of Heavy Hetals on Survival and Respiration Rate of Tubificid Horms: Part II -

Effects on Respiration Rate," Environmental Pollution, 13:93-98 (1977).

Brown, V.H., "Aspects of Heavy Metals Toxicity in Fresh Waters," Proceedings of the International Joint Commission's Morkshop on Toxicity to Biota of Metal porms in Natural water, October 7-8, 1975. Duluth, Minn.., pp. 59-75 (April 1976).

Buikema, A.L., Jr., J. Cairns, Jr., and G.H. Sullivan,

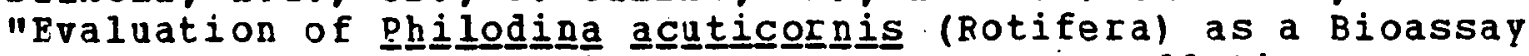
organism for heavy Metals," Hater. Resources Bulletin, $10(4): 648-661(1974)$.

Buikema, A.L., Jr., D.R. Lee, and J. Cairns, Jr., "A Screening Bioassay Using Daphnia pulex for Refinery hastes Discharged into Freshwater," Journal of Testing and Evaluation, $4(2): 119-125$ (1976).

Cairns, J., Jr.. "Effects of Increased Temperatures Opon Aquatic Organisms," Engineering Bulletin of Purdue University, $40(1): 346$ (1956).

Cairns, J.. Jr. and A. Scheier, "Effects of Temperature and Hardness of Water opon the Toxicity of Potassium Dichromate to the Common Bluegill sunfish," Transactions of the Northeastern wildife Conference, 10th Annual Meeting, Montreal, pp. 86-98 (Jan. 4-7, 1958). 
Cairns, J., Jr. and A. Scheier, "Relationship of Bluegill Sunfish Body Size to Tolerance for Some common Chemicals," Industrial Wastes, $3(5): 126$ (1958).

Cairns, J.. Jr. and $\Lambda$. Scheier, "Effects of periodic Low Oxygen "pon the Toxicity of Various Chemicals to Aquatic organisms," proceedings of the 12 th Industrial Waste Conference, Purdue Iniversity Enqineering Extension Series, 94:165-176 (1958).

Cairns, J., Jr, and A. Scheier, "A Comparison of the Toxicity of Some Common Industrial waste components Tested Individually and Combined," Progressive Bish-Culturist, 30 (1):3-8 (1968).

Calabrese, A., et al., "Toxicity of Heavy Metals to Embryos of

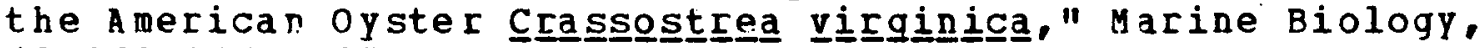
$18: 162-166$ (1973).

Cearley, J.E., "Toxicity and Bioconcentrations of Cadmium,

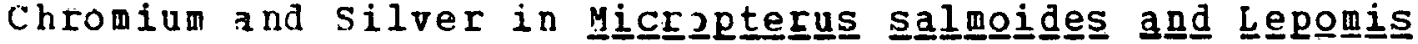

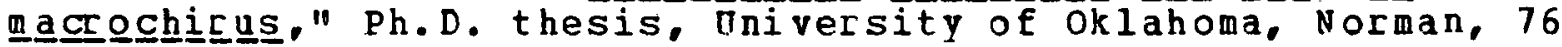
pp. (1971).

Chaisemartin, C., "pefects of Chromium (K2Cr04) on Respiratory Metabolist and water and Mineral Balance in Tuo Freshwater Benthic Insect T.arvae." Societe de Biologique de Poitiers, $169: 384$ (1974).

Cheremisinoff, P. and Y. Habib, "Cadmium, Chromium, Lead, and Mercury - Plenary Account for water Pollution $I$. Occurrence, Toxicity, and Detection," tater and Sewage Works, 119:73 (1972).

Decker, C.F., C.A. Hoppert, and B.U. Byerrum, "Report on Toxicity studies of Cadmium and Chromium," Journal of the American Water works Association, $48: 1279$ (1956).

Pisler, R. and P.J. Hennekey, "Acute Toxicities of Cd2+, Cr6+, Ha2+, Ni2+ and Zn2+ to Estuarine Macrofauna," Archives of Environmental Contamination and Toxicology, 6:315 (1977).

Fairchild, E.J.. "Low Dissolved Oxyqen: Effect Tpon the Toxicity of Certain Inorqanic Salts to the Aguatic Invertehrate ㅁạnh maqㅡㅁ. " Louisiana State Tniversity Engineering Research Bulletin, Baton Rouge, 51:95-102 (1955).

Federation of Sewage and Industrial wastes Associations, "Toxicity of Mercuric Chloride, Chromic Sulfate, and Sodium Chromate in the Dilution B.O.D. Test," Sewage and Industrial wastes, $26(4): 536-538$ (1954).

Fromm, P.o.. "Toxic Action of water soluble pollutants on Freshwater Fish," EPA Hater Follution Control Research Series No. 18050 ST, U.S. Government Printing office, Washington, D.C. (1970): Michigan State Oniversity Water Pollution Control Research Series, East Iansing (1970). (NT IS PB-201 650) 
Fromm, P.O. and R.H. Schiffman, "Toxic Action of Hexavalent r.hromium on Larqemouth Bass," Journal of Hildife Management, $22(1): 40-44(1958)$.

Fromm, P. O. and R.M. Stokes, "Assimilation and Elimination of Chromium by Trout," Journal of the Water Pollution Control Feder ation, 34 (11): 1151-1155 (1962).

Garton, R.R., "Biological Effects of Cooling Tower Blowdown," Presented at the $71 \mathrm{st}$ Annual Meeting of the American Institute for Chemical Engineers, Dallas, 25 pp. (1972).

Graham, D.H., "Chromium - A Water and Sewage Problem," Journal of the American Water Horks Association, 35:159 (1943).

Great Lakes Laboratory, "Chromium, Cadmium, Arsenic, Selenium, Mercury, and Aquatic Life: A Brief Iiterature Review," state University College at Buffalo, N. I.. Special Report No. 9 (1971).

Grindley, J., "Toxicity to Rainbow. Trout and Iinnows of Some Substances Known to be Present in Naste Water Discharged to Bivers," Annals of Applied Bioloqy, 33:103-112 (1946).

Hermann, E.R., "A Toxicity Index for Industrial Hastes," Industrial and Fngineering Chemistry, 51:84A-87A (1959).

Hervey. J.R., "Effect of Chromium on the Growth of onicellular Chlorophyceae and Diatoms," Botanical Gazette, 3(1):1-11 (1949).

Ingols, R.S., "Toxicity of Hexavalent Chromiun to Bluegills," Journal of the water pollution Control Federation, 32:869-877 $(1960)$.

Ingols, R.S. and E.S. Kirkpatrick, "Study of Chromiun Toxicity by Several oxygen Demand Tests," Analytical Chemistry, $24(12): 1881-1884$ (1952).

Jenkins, D.W.. "Flow of Toxic Metals in the Environment," International Conference on Environmental sensing and assessment, Vol. I, I as Vegas, Nev. (Sept. 14-19, 1975).

Jones, J.R.F.. "Antagonism Between Salts of the Reavy and Alkaline-Earth Metals in Thoir Toxic action on the Tadpole of the

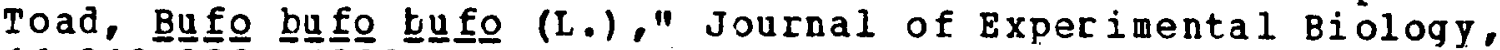
$16: 313-333(1939)$.

Jones, J.R.F.. "The Relation Between the Electrolytic solution Pressures of the llals and Their Toxicity to the stickleback

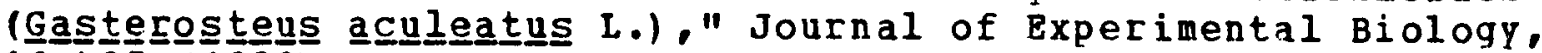
$16: 425(1939)$.

Jones, J.R.E., "A Study of the Relative Toxicity of Anions with

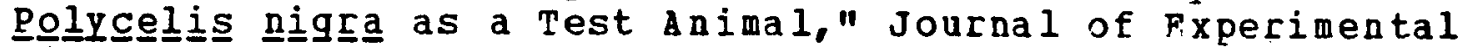
Bioloqy, 18:170-181 (1941). 
Kerfoot, H.B. and G.A. Redmann, "Rerwissible Levels of Heavy Metals in Secondary Effluent for use in a Combined Sewage Treatment-harine Agriculture system II. Development of Guidelines by fethod of Additions, "proceelings of the conference on rastenter Use in the production of pood and Piber, oklahona city, Okla., pp. 79-101 (March 5-7, 1974).

Klassen, C.W.., H. Haseurther, and M.K. Yound, "Toxjcity of Hexavalent Chromiug to Suntish ard Bluegills," Proseedings of the 4th Industrial. Haste Conference, Purdue oniversity Engineering Bulletin, Extension Sories No. 68:229-237 (1949).

Koelling, J.J.. "Relationship of Trace Elements to Algae Growth" $\mathrm{Ph} . \mathrm{D}$. thesis, Hashirgton state oniversity, pullman (1971).

Kopp, J.F. and F.C. Kroner. "Trace Metals in katers of the U.S.: A Five Year Study of Trace tetals in Rivers and Lakes in the G.S. loct. 1, 1962 - Sept. 30, 1967), U.S. Department of Interior, Federal ater pollution control a üministration, cincinnati, Jhio, 32 pp. (1968).

McIntosh, A, and Bishop, "Distribution and Effects of Heary Metals in a Containated Lake, Technical Report No. 85. OHRT/A-036-IND (1), U.S. Department of Commerce, NTIS. springfie1d。

Mackenzie, R.D."C.A. Hoppert, and R.U. Byerrua, "Studies of Cacomiun and Chromiun solubility and Toxicity "Journal of the Allerican Hater Norks Association, 49:1310 (1957).

Moraan, R.P." II. et al." "Snblethal effects of Raltimore Harbor Water on the Hhite Perch, Morone arericana, and the Hogchoker,

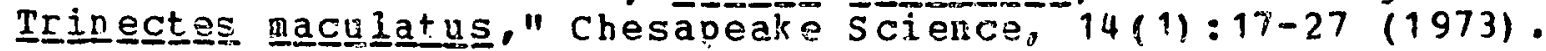

Murdock, H.R., "Industrial lastes: Some Data on Toxicity of Metals in wastes to Fish Li $\in$ s are presented," Industrial Frgineering and chemistry. 45:998 (1953).

Nakani, D. V. and M.N, Korsak; "Effect of Chromium, Cadmium, and zinc on the Rate of Photosynthesis in Short-Term Experiments," Bioloqicheskie na uki, 19(9):84 (1976).

Negilski, D.S. "Acute Toxicity of Zinc, Cadmium and Chromium to the Marine Fishes, Yellow-Eye Mullet (s ld Iichetha forsterí C. \& $\nabla$.$) and Sma 11-Monthed Hardyhead (Atherinasoma microstoma$ whitleyl, "Australian Journal of Marine and Freshwater Research, 27:137(1976).

Office of water Resources Research, "Chromium in vater: A Bibliography," U. S. Department of the Interior, Mashington, D.C., WBSIC $72-205(1972)$. 
Olson. K.R. and R.C. Harrel, "Fffect of Salinity on acute

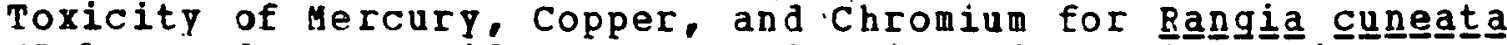
(Pelecypoda, Mactridae)," Contributions in Marine Science, $17: 9-13(1973)$.

olson, P.A.. "Comparative Toxicity of $\mathrm{Cr}$ (VI) and Cr(III) in Salmon," Hanford Biology Research Annual Report for 1957, Report No. HW-53500, p. 215 (1958).

Olson, P.A. and B.F. Foster, "Effect of Chronic Exposure to Sodium Dichromate on Young Chinook. Salmon and Rainbow Trout," Battelle Pacific Northwest Laboratory Report Hn-41500, pp. 34-47 (1956).

Oshida, P.S.." "A Safe Level of Hexavalent Chromium for a Marine Polychaete," Coastal Rater Research Project Annual Report, 169 (1977).

Patrick, F.M. and M.W. Loutit., "Passage of Metals in Effluents, Through Bacteria to Higher Organisms," Water Research, 10:333-335 (1976).

Pickering, O.H. and C. Henderson, "Acute Toxicity of Some Heavy Metals to Different Species of Narm Nater Fishes, "International Journal of Air and Water Pollution, 10:453-463 (1966).

Poon, C.P.C. and K.H. Bhayahi, "Metal Toxicity to Sewage Organisms," proceedings of the American Society of Civil Engineers, Journal of the Sanitary Engineering Division, Vol. 97 $(1970)$.

Preston, E.M.. "The Importance of Inqestion in Chromium-51

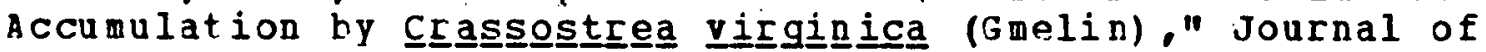
Experimental Marine Biology and Ecology, 6:47-54 (1971).

Raymont, J.E.G. and J. Shields, "Toxicity of Copper and Chromium in the Marine Environment," Advances in Water Pollution Research, E.A. Pearson, (ed.), Macmillan, New York (1964).

Reish, D.J., et al., "The Effect of Heavy Metals on Laboratory populations of. Two Polychaetes with Comparisons to the Water Quality conditions and standards in Southern California Marine Waters," Water Besearch, 10:299-302 (1976).

Ruesink, R.G. and L.L. Smith, Jr., "Relationship of the 96-Hour IC50 to the Lethal Threshold Concentration of Hexavalent Chromium, Phenol, and sodium Pentachlorophenate for Fathead

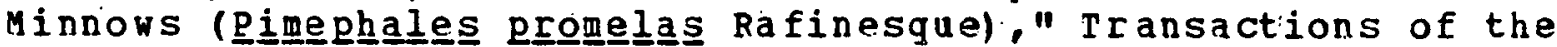
American Eisheries society. 3:507-569 (1975).

Ruthven, J.A. and J. Cairns, Jr., "Response of Fresh-Water Protozoan Artificial Communties to Metals," Journal of Protozooloqy. 20(1):127-135 (1973). 
Saurent, P., "Resistance of Freshwater crustaceans to the Action of Sodium Chromate," Verhandlungen Internationale Vereinigung fur Theoretische und Angevandte Iimnologie, 14:590 (1956).

Sauter, S., et al., "Effects of Exposure to Heavy Metals on Selected Freshuater Fish, Toxicity of Copper, Cadmium, Chromium and lead to Eggs and Pry of Seven Fish Species," U.S.

Environmental Protection Agency Report EPA-60n/3-76-105, Duluth, Minn., 75 po. (1976).

Schaefer, E.D. and H.O. Pipes, "Temperature and the Toxicity of

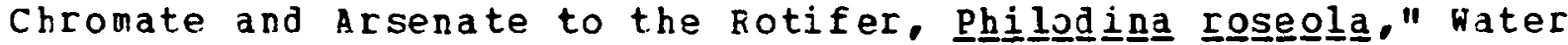
Research, 7(12): 1781-1790 (1973).

Scheier, A. and P. Kiry, "A Discussion of the Effects of Certain Potential Toxicants on Fish and shellfish in the Upper Delaware Estuary," Academy of Natural Sciences of Philadelphia. Penn. (Dec. 1973). (NTIS PB-231423)

Schiffman, R.b. and P.D. Fromm, "Chromium-Induced changes in the

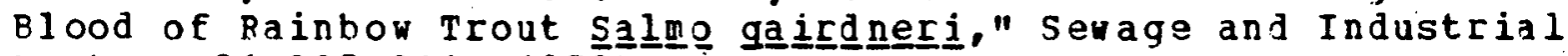
Wastes, 31:205-211 (1959).

Schindler,.J.F. and J.J. Alberts, "Behavior of Mercury, Chromium, and Cadmium in Aguatic Systems," O.S. Environmental protection agency, EPA-600/3-77-023, Athens, Ga. (1977).

Silaichuk, F.V.. "The Effects of waste waters Containing Cyanides and Hexavalent Chromium on the viability of certain Aquatic orqanisms," Gigjena i Sanitariya, 34:78-79 (1969).

Strik, J., et al.. "Toxicity of Chromium (VI) in Fish, with special Reference to organoweights. Liver, and Plasma Enzyme Activities, Blood Parameters ard Histological Altorations," Sublethal Effects of Toxic Chemicals on Aquatic Animals, proceedings of the Swedish-Netherlands Symposium, raqeningen, Netherlands, vol. 31 (1975).

Sudo, G. and S. Aiba, "Effect of Copper and Hexavalent Chromium on the Specific Growth Rate of Ciliata Isolated from Activated-sludge," Water Research, 7(9):1301-1307 (1973).

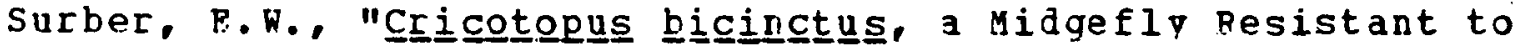
Electroplatinq Wastes." Transactions of the American Fisheries Society. 88(2):111-116 (1959); Biological Abstracts, 35:9533 $(1960)$.

Trabalka, J.R. and C. T. Gehrs, "An Observation of the Toxicity of Hexavalent Chromium to Daphnnia magnga," Toxicology Letters, 1:131 $(1977)$.

Trama, F.B. and P.J. Benoit, "Acute Toxicity of Hexavalent Chromium to the common Eastern Sunfish," presented at the 134th Meeting of the American Chenical society. Chicago (1958). 
Trama, F.B. and R.J. Benoit, "Toxicity of Hexavalent Chromi um to Bluegills," Journal of the Nater Pollution Control Federation, $32(8): 868-877(1960)$.

Turnbull, H., J.G. DeMann, and R.F. Weston, "Toxicity of Various Refinery Metals to Freshwater Fish." symposium on Waste Disposal in the Petroleum Industry. Industrial Engineering and Chemistry, $46: 324(1954)$.

U.S. Department of the Interior. "Chromium in Water - A Bibliography," office of Water Resources Research Beport WRIC 72-205, 126 pp. (June 1972). (NTIS PB 210921 )

Narnick, S.L. and H.L. Bell, "Acute Toxicity of some Heavy Metals to Different species of Aquatic Insects," Journal of the Water Pollution Control Federation, 41(2):280-284 (1969).

Whitton, B.A., "Toxicity of Heavy Metals to Freşhater Algae: A Review,": Phykos, 9 (2): 116-125 (1970).

Zehmpfenning. R.G.. "Possible Toxic Effects of Cyanates, Thiocyanates, Ferricyanates, Ferrocyanides and chromates Discharged to surface Nater," proceedings of the 22 nd Industrial Waste Conference. Engineering Bulletin of Purdue University. $52(3): 879-883$ (July 1968).

\section{COBALT}

Amiard; J.C., "Experimental study of Acute Toxicity of Salts of Cobalt, Antimony, strontium and Silver in Crustaceans and Their Larvae and in Some Teleosts," Revue Internationale d'Oceanographie Medicale, (in French), 43:79-95 (1976): Selected Water Resources Abstracts, 1C: $177-07728$ (1977).

Andrew, R.H., K.E. Biesinger, and G.E. Glass, "Effects of

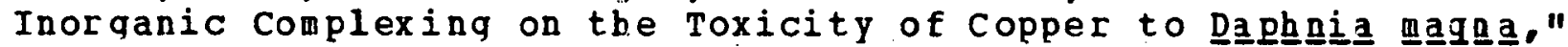
Water Research, 11:309-315 (1977).

Boothe, P.N. and G.A. Knauer, "Possible Importance of Fecal Material in the Biological ampification of Trace and Heary Metals," Limnology and Oceanograph.y. 17(2):270-275 (1972).

Buikema, A.L., Ir., J. Cairns, Jr., and G.W. Sullivan,

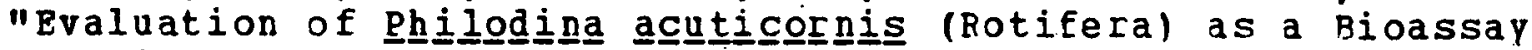
organism for Heavy Hetals," water Resources Bulletin, $10(4): 648-661(1974)$.

Carter, J.W. and I.L. Cameron, "Toxicity Bioassay of Heavy Metals

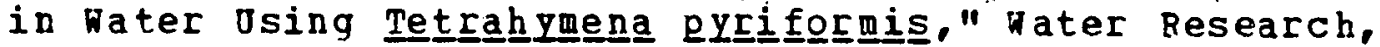
7(7): $951-961$ (1973). 
Coleman, R.D.. R.I. Coleman, and E.L. Rice, "Zinc a nd cobalt Rioconcentration. and Toxicity in selected Algal species," Botanical Gazette, 132:102-109 (1971).

Hutchinson, T.C., "Comparative studies of the Toxicity of Heary Metals to phytoplankton and Their synerqistic Interactions," water Dollution Research in Canada, 8:68-90 (1973).

Jenkins, D.W." "Flow of Toxic Metals in the Environment," International conference on Environmental sensinq and Assessment, Vol. I, Las Vegas, Nev. (Sept. 14-19, 1975).

Jenne, E.A., "Controls on Mn, Fe, Co, Ni, Cu, a nd $\mathrm{Zn}$ Concentrations in Soils and water: The Siqnificant Role of Hydrous Mn and Fe Oxides," Advanced Chemistry, 73:337-387 (1968).

Koelling, J.J.. "Relationship of Trace Elements to Alqae Growth," Ph.D. thesis, Washington state University. Qullman (1971).

Kuenzler, E.J.. "Elimination and Transport of Cobalt by Marine Zooplankt on," Symposium on Radioecology. D.J. Nelson and F.C. Evans, (eds.), Oak Ridge, U.S. Atomic Enerqy Commission Technical Information Division, pp. 483-492 (1969).

Kuenzler, E.J., "Elimination of Iodine, Cobalt, Iron and zinc by Marine Zooplankton," Symposium on Radioecology. D.J. Nelson and F.C. Evans, (eds.), Oak Ridge, U.S. Atomic Energy Commission Technica 1 Information Division, pp. 462-473 (1969).

Nakahara, M., et al.. "Concentration of Radioactive Cobalt by Seaweeds in the Food Chain," Impact of Nuclear Releases into the Aquatic Environment. International atomic snergy aqency Report IAF - SM-3-1 (1975).

Nishikawa, K. and K. Tabata, "Studies on the Toxicity of Heavy Metals to Aguatic Animals and the Factors to Decrease the Toxicity III. On the Low Toxicity of Some Heary Metal complexes to Aquatic Animals," Bulletin of Tokai Reqional Fisheries Research Laboratory, 58:233-241 (1969).

Pentreath, R.J.. "The Accumulation from water of $65 \mathrm{zn}, 54 \mathrm{Mn}$, 58Co, 59Fe by the Mussel Mytillus eduliss," Journal of the larine Bioloaical Association of the United kingdom, 53:127-143 (1973).

Rosco, J.J. and J.H. Rachlin, "Effects of Copper, Zinc, Cobalt;

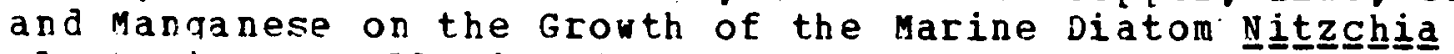
closteㅗ프므," Bulletin of the Torrey Botanical Club, 102:100 $(1975)$.

Ruthven, J.A. and J. Cairns, Jr.. "Response of Fresh-Water protozoan Artificial Communities to Metals," Journal of Protozoology. 20(1):127-135 (1973). 
Salzinger, K., et al., "Behavior of the Goldfish as an Early Marning system for the presence of pollutants in Nater," Journal of Environmental Systems, 3(1):27-40 (Spring 1973).

Slater, J.V.. "Influence of Cobalt on the Growth of the Protozoan, Tet

Soder gren, S., "Ecological Effects of Heary Metal Discharge in a Salmon River," Drottningholm, Sweden, Institute of Freshwater Research, Report 55:91 (1976).

Tabata, K., "Studies on the Toxicity of Heavy Metals to Aquatic Animals and the Factors to Decrease the Toxicity I. On the Formation and the Toxicity of Precipitates of Heary letals," Bulletin of Tokai Regional Pisheries Research Laboratory, $58: 203-214(1969)$.

Tabata, K.. "Studies on the Toxicity of Heary Metals to Aquatic Animals and the Factors to Decrease the Toxicity II. Antagonistic Action of Hardness Components in Mater on the Toxicity of Heavy Metal Ions," Bulletin of Tokai Regional Pisheries Research Laboratory, 58:215-232 (1969).

Tabata, K., "Studies on the Toxicity of Heary Metals to Aquatic Animals and the Pactors to Decrease the Toxicity IV. On the Relation Between the Toxicity of Heavy llats and the Quality of Environmental Water," Bulletin of Tokai Regional Pisheries Research Laboratory, 58:24 3-253 (1969).

\section{COPPEB}

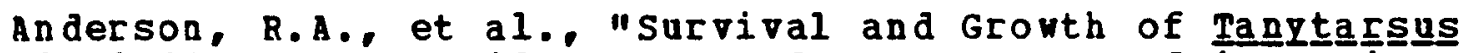
dissisimilas (Chronomidae) Exposed to Copper, Cadmium, zinc, and Nickel," National Environgental Research Laboratory, Duluth, Minn., Quarterly Reports (1975).

Anderson, R.V., "Cadmium, Copper, Lead, and Zinc: Tracemetal Pollutants in an Aquatic Ecosystem," NSE-SOS Grant GY-10814 Final Report, National Science Foundation, Rashington, D.C., 275 pp. (1973).

Anderson, R.V.. "The Occurrence of Cadniut, Copper, Lead, and zinc in Macroinvertebrates of the Fox River, Illinois," Onpublished M.S. thesis, Department of Biological science, Northern Illinois Oniversity, DeKalb, 134 pp. (1975).

Anderson, R.V., "Concentration of Cadmium, Copper, Lead, and zinc in Thirty-Five Genera of Preshwater Macroinvertebrates From the Fox River, Illinois and Risconsin," Bulletin of Environmental Contamination and Toxicology, 18(3):345-349 (1977). 
Anderson, R.V., "Concentration of Cadmium, Copper, Lead and zinc in Six species of Freshwater Clams," Bulletin of Environmental Contamination and Toxicology, 18(4):492 (1977).

Anderson, R.V., H.S. Vinikour, and,J.E. Brower, "The Distribution of $\mathrm{Cd}, \mathrm{Ca}, \mathrm{Pb}$ and $\mathrm{Zn}$ in the Biota of Two Freshwater Sites with Different Trace Metal Inputs." Holarctic Ecology, 1:377-384 $(1978)$.

Andrew, R.R.. K.E. Biesinger, and G.E. Glass, "Effects of Inorganic Complexing on the Toxicity of Copper to Dạphania magana.," nater Research, 11:309-315 (1977).

Arthur, J.W. and E.N. Leonard, "rffects of Copper on Gammaraús pseudolimnaeus, physa integra, and Campelona decisung in soft vater," Journal of the Fisheries Research Board of Canada, 27 (7): 1277-1283 (1970) .

Aubert, M., et al., "Otilization of a Trophodynamic Chain of a Pelagic Type for the Study of Transfer of Metallic Pollution," Revue Internationale d'oceanographie redicale, 28:27-52 (1972).

A ubert, M... et al.. "Bse of a Neritic Trophodynamic Chain of Molluscs for the study of the Transfer of Metallic Pollutants," 6 th symposium of the Internationale doceanographie lledicale, Portoroz, Yugoslavia (Sept. 26-30, 1973); Revue Internationale d'Oceanographie Medicale, 33:7-30.(1973). (NTIS CONP-7309103-1)

Baker, J.T.P., "Histological and Electron Microscopical Observations on Copper Poisoning in the winter plounder

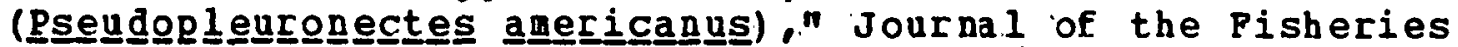
Research Board of Canada, 26:278:5-279.3 (1969).

Barica, J.. M.P. Stainton, and A.L. Hamilton, "Hobilization of Some Metals in vater and Animal rissue by. NTA, EDTa and TPP," water Res earch, 7:1791-1804 (1973).

Barnes, H. and F.A. Standbury, "Toxic Action of copper and Mercury Salts Both Separately and When Mixed on the Harpactacid

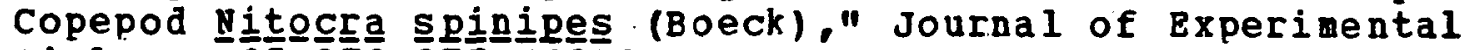
BioloqY, $25: 270-275$ (1948).

Barsdate, R.J., "Pathways of Trace Elements in Arctic Lake Ecosystems," University of llaska, Fairbanks, Institute of Marine Science, (1972). (NTIS RLO-2229-T2-1)

Bartlett, L.. F.. . Rabe, and R.H. Bunk, "Effects of Copper, Zinc

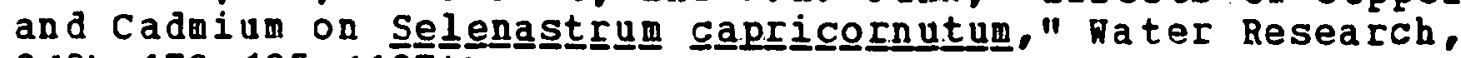
$8(3): 179-185(1974)$.

Beers, J.R., G.I. Stevart, and R.D. Hoskins, "Dynamics of Micro-zooplankt on Populations Treated with Copper: Controlled Ecosystem Pollution Experiment," Bulletin of Marine science, $27(1): 66-79$ (1977). 
Benoit, D.A., "Chronic Effects of Copper on Survival, Growth, ard Reproduction of the Bluegill (Lepomis macrochirgus), "Transactions of the merican Fisheries Society, $104(2): 353-358$ (1975).

Bentley-Howats J.A. and S.M. Peed, "Survival of Marine Phytoplankton in Bigh Concentrations of Heary Hetals, and Uptake of Copper." Journal of Experimental Marine Bioiogy and Ecology. $26: 249(1977)$.

Betzer, S.B., "Copper Metabolism, Copper Toxicity, and a Review of The Function of Hemocyanin in Busycon canaliculatug $\ldots$., $P h . D$. dissertation, University of Rode Island, 133 pp. (1972).

Betzer, S.B. and M.E.Q. Pilson, "The Seasonal Cycle of Copper concentration in Buㅗ프음 canal $146(2): 165-175(1973)$.

Betzer. S.B. and H.E.0. Pilson, "Copper uptake and Excretion by Busycon canaliculatug L. " Biological Bulletin, 148(1):1-15. $(1975)$.

setzer, S.B. and P.P. Yevich, "Copper Toxicity in Busycon

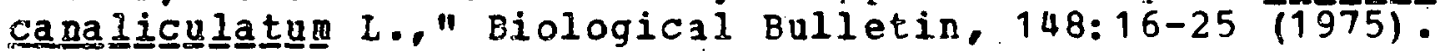

Geyerly, G.B. and J.E. Williams "Attempted Control of Bluegill tieproduction in Lakes by the Application of Copper sulfate Erystals to sparning Nest," Progressive Fish-Culturist, $29(3): 150-155(1967)$.

Biesinger, K.E. and G.M. Christensen, "Effects of Various Metals on Survival, Growt heproduction, and Metabolisa of Dáphngia magna." Journal of the Fisheries Research Board of Canada, $29(12): 1691-1700$ (1972).

Bilinski, E. and R.E.E. Jonas, "Effects of Cadmium and Copper on the Oxidation of Lactate by Rainbow Trout (salㅡㅇㅡ qai Gills," Journal of the Fisheries Research Board of Canada. $30(10): 1553-1558 \cdot($ oct. 1973).

Black, G.A.P., et al.. "Annotated List of copper concentrations Found Harmful to Aquatic Organisms," Fisheries and Marine Service Technical Report No. 603, Environment Canada, Burlington, ontario. $44 \mathrm{pp}$. (1976).

Black, J.A., "Effect of Certain Organic pollutants on Copper Toxicity to Fish," Ph.D. thesis, University of Michigan, Ann Arbor (1974).

Blaxter, J.H.S., "The Effect of Copper on the Eggs and Larvae of Plaice and Herring," Journal of the Marine Biological Association, $57: 849$ (1977). 
Boothe, P.N. and G.A. Knauer, "Possible Importance of Fecal Material in the Piological Amplification of Trace and Heavy Metals," Limnology and oceanography, 17(2):270-275 (1972).

Bovee, E.C.. "Effects of Selected Chemicals on Movement, Growth, and Survival of Certain Aqutic Animal Life," National Technical Information Service, Report No. PB-261 388 (1976).

Rraek, G.S.G., A. Jensen, and A. Mohus, "Heavy Metal Tolerance of Marine Phytopiankton III. Combined Effects of Copper and Zinc Ions on cultures of Four Common Species," Journal of Experimental Marine Biology and Ecology, 25(1):37-50 (1976).

Bringmann, G. and R. Kuhn, "The Toxic Effects of waste water on Aquatic Bacteria, Alqae, and Small Crustaceans," Gesundheits-Ingenieur, 80:115 (1959).

Brinqmann, G. and R. Kuhn, "water Toxicity studies with Protozoans as Test Orqanisms," Gesundheits-Inqenieur, 80:239 $(19.59)$.

Brkovic-Popovic, I. and M. Popovic, "Effects of Heavy Metals on Survival and Respiration Rate of Tubificid Worms: Part I Effects on Survival," Environmental Pollution, 13:65-72 (1977).

Brkovic-Popovic, I. and M. Popovic, "Effects of Heavy Metals on Survival and Respiration Rate of Tubificid Horms: Part II Pffects on Respiration Rate," Environmental Pollution, 13:93-98 $(1977)$.

Brown. B.E.. "Observations on the Tolerance of the Isopod Asellus

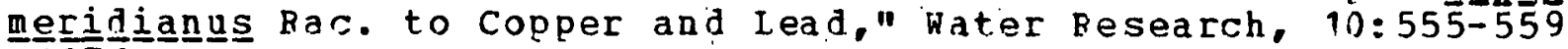
$(1976)$.

Brown, B.E.. "Fffects of Mine Drainage on the River Hayle, Cornwall: A) Factors Affecting concentrations of copper, zinc and Iron in water. Sediments and Dominant Invertebrate Fauna," Hydrobiologia, $52(2 / 3): 221-233$ (1977): Biological Abstracts, $13612(1977)$.

Brown. B. B., "Uptake of copper and Lead by a Metal-Tolerant

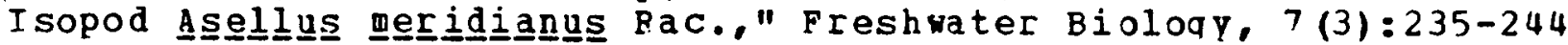
$(1977)$.

Brown. B.E. and R.C. Newell, "Effect of Copper and zinc on the Metabolism of the Mussel Mytilus edulis," Marine Biology. $16: 108-118$ (1972).

Brown, V.M.. "The Calculation of the Acute roxicity of Mixtures of Poison to Rainbow Trout." Water Research, 2(10):723-733 $(1968)$. 
Brown, V.M.. "Aspects of Heavy Metals Toxicity in Presh Waters," Proceedings of the International Joint Commission's Workshop on Toxicity to Biota of Metal Porms in Natural water, october 7-8, 1975. Duluth, Minn..,pp. 59-75 (April 1976).

Brown, V.M. and R.A. Dalton, "The lcute Lethal Toxicity to Rainbow Trout of Mixtures of Copper, Phenol, Zinc and Nickel, Journal of Fisheries Biology, 2:211-216 (1970).

Brown, V.M.. T.I. Shaw, and D.G. Shurben, "Aspects of Nater Quality and the Toxicity of Copper to Rainbow Trout," Mater Research, 8:797-803 (1974).

Brungs, W.A., J.R. Geckler, and M. Gast, "Acute and Chronic Toxicity of Copper to the Fathead Minnow in a Surface Nater of Variable Qualit,$"$ Water Research, 10:37-43 (1976).

Brungs, M.A., E.N. Leonard, and J.M. MCKim, "Acute and Long-Term

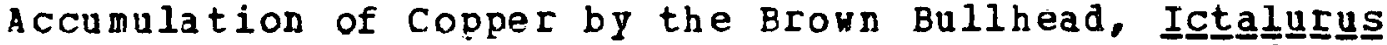
nebulosus." Journal of the Pisheries Research Board of Canada, $30(4): 583-586(1973)$.

Brungs, W.A., et al.. "Acute and chronic Toxicity of copper to the Fathead Minnow in a Surface Water of Variable Quality," Nater Research, 10:37 (1976).

Bryan, G.W.. "Zinc Requlation in the Preshwater Crayfish (Including some Comparative Copper Analyses). "Journal of Experimental Biology, 46:281-296 (1967).

Bryan. G.W:. "Some Aspects of Heavy Metal Tolerance in Aquatic Organisms," A.P.M. Lockwood, (ed.), Cambridge University Press, N.Y., 35 pp. (1977).

Bryan, G.W. and I.,G. Hummerstone, "Adaptation of the Polychaete Nereis diversicolor to Estuarine sediment Containing High Concentrations of Heary Metals $I$. General observations and Adaptation to Copper," Journal of the Marine Biological Association of the United Kingdom, 51 (4): 845 (1971).

Bryan, G.H. and L.G. Hummerstone, "Adaptation of the polychaete

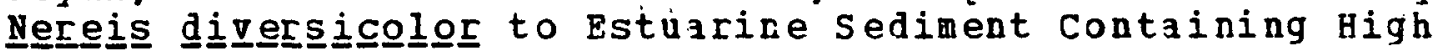
Concentrations of Zinc and Cadmium," Journal of the Marine Biological Association of the United Kingdom, 53(4):839-857 (1973).

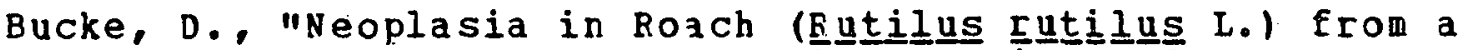
Polluted Environment," Progress in Experimental Tumor Research. $20: 205(1976)$.

Buikena, A.L., Jr., J. Cairns, Jr., and G.H. Sullivan, "Evaluation of Philodina acuticornis (Rotifera) as a Bioassay orqanism. for Heavy Metals," Water Resources Bulletin. $10(4): 648-661(1974)$. 
Button, D.K. and S.S. Dunker, "Biological effects of Copper and Arsenic Pollution," Oniversity of Alaska, Fairbanks, Institute of Marine science Report R71-8, 59 pp. (April 1971). (NTIS PB-201 648)

Cairns, J., Jr, and K.L. Dickson, "Reduction and Restoration of the Number of Freshwater Protozoan Species Pollowing acute Exposure to Copper and Zinc," Transactions of the kansas Academy of science, 73:1-10 (1970).

Calabrese, A.. et al.. "Toxicity of Heavy Meta is to Bmbryos of

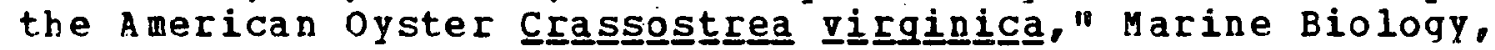
$18: 162-166$ (1973).

Calabrese, A.. et al.. "Survival and Growth of Bivalve Larvae under Heavp-Metal Stress," Marine Biology, 41:179-184 (1977).

Calamari, D. and R. Marchetti, "Predicted and observed Acute

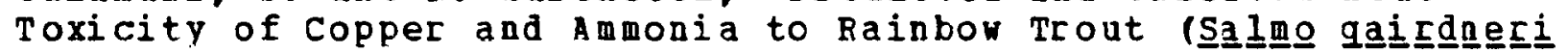
Rich.)." Water Pollution Research Proceedings, S.H. Jenkins, (ed.). Perqamon. New York, pp. 569-576 (1975) : Progress in Water Technology, $7(3 / 4): 569-577$ (1975) .

Carson, W.G." "Avoidance of Copper in the presence of Humic Acid by Juvenile Atlantic Salmon," Fisheries Research Board of Canada us Report No. 1237, 9 pp. (1973).

Carson, W.G. and H.V. Carson, "Toxicity of Copper and zinc to Juvenile salmon in the Presence of Humic Acid and Lignosulfates," Fisheries Research Board of Canada MS Report No. 1181, 5 pp. (1972).

Cedenoma, A. and J.A. Swader, "Studies on Mechanism of Copper

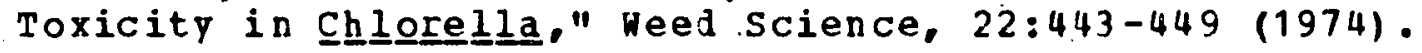

Chapman, G.. "Effect of Heavy Metals on Fish," oregon State University Water Resources Research Report No. SEMN-NR-D 16.73, pp. 141-162 (Jan. 1973).

Chena, T.C. and J. Sullivan, "Mode of Entry, Action, and Toxicity of Copper Molluscicides," Molluscicides in Schistosomiasis Control, T.C. Cheng, (ed.), Academic Press, New York, pp. 89-153 (1974).

Christensen, G.M. et al.. "Changes in the Blood of the Brown

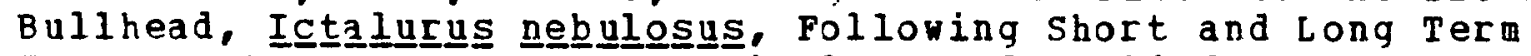
Exposure to Copper (II)." Toxicology and Applied Pharmacology. $23(3): 417-427$ (1972).

Conner, D.M. "Acute Toxicity of Heavy Metals to Some Marine Larvae," Marine Pollution Bulletin, 3(12):190-193 (1972). 
Cook, R.H. and R.P. Cote, "Influence of Humic Acids on Toxicity of Copper and zinc to Juvenile Atlantic salmon as Derived from the Toxic onit Concept," Canadian Environmental Protection Service, US Report No. $72-2,27$ pp. (1972).

Cook, R.H. and R.A.H. Hoos, "Base Metal Mine Water Pollution on the Nipisiquit River, New Brunswick," Canadian Research and Development Branch, MS Report 71-2, 27pp. (1971).

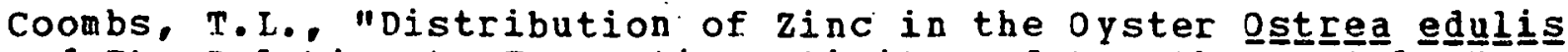
and Its Relation to Enzymatic Activity and to other retals," Marine Biology, 12:170-178 (1972).

Corner, B.D.S. and B. H. Sparrow, "Modes of Action of Toxic Agents I. Observation of the Poisoning of Certain crustaceans by Copper and Mercury," Journal of the Marine Biological Association of the United Kingdom, 35:531-548 (1956).

Coughtrey. P.J. and M.H. Martin, "The Uptake of Lead, Zinc, Cadmium, and Copper by the Pulmonate Mollusc, Helix Muller, and Its Relevance to the Monitoring of Heavy Metal Contamination of the Environment," Oecologia, 27:65-74 (1977).

Courtois, L.A., "Copper Intoxication - A Possible Biochemical Homologue." Bulletin of Environmental Contamination and Toxicology, $15(2): 205-210$ (1976).

Crance, J.H., "Effects of Copper Sulfate on Microcystis and Zooplankton in Ponds," Progressive Fish-culturist, 25 (4):198-202 (1963).

D'Agostino, A. and. C. Finney, "The Effect of Copper and Cadmium

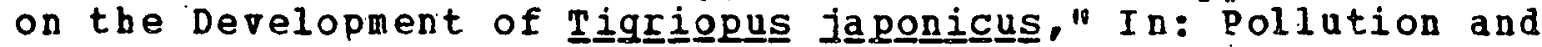

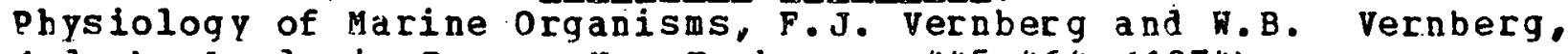
(eds.). Academic Press, New York, pp. 445-464 (1974).

Danie1s, R.R.. B.E. Struckmeyer, and L.A. Peterson, "Copper

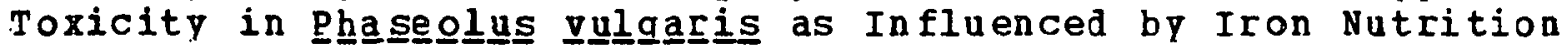
II. Elemental and Electron Microscope Analysis," Journal of the American Society for Horticultural Science, 98:31-34 (1973).

Davenport., J., "A Study of the effects of Copper Applied Continuously and Discontinuously to specimens of 보느는 ed (L.) Exposed to steady and Fluctuating Salinity Levels," Journal of the Marine Biological Association, 57:63 (1977).

De Calventi, I.B.. "Copper Poisoning on the snail Helixㅗ poomatia and Its Effect on Mucous Secretion." Annals of the New York Academy of Sciences, $118(24): 1015-1020$ (1965).

De L.G. Solbe, J.F. and V.A. Cooper, "Studies on Toxicity of Copper Sulphate to $S$ tone Loach, №enacheilus barbatuulus (L.) in Hard Nater," Hater Research, 10:523-527 (1976). 
Delhaye, W. and D. Cornet, "Contribution to the study of the Effect of Copper on Eytilus edulis During Reproductive Period," Comparative Biochemistry and Physioloqy, 50A:511-518 (1975).

Dilling, H.J. and C.H. Healey, "Influence of Lead and the Metallic Ions of copper, Zinc, Thorium, Beryllium, and Thallium on the Germination of Frogs' Spawn and on the Growth of Tadpoles," Annals of Applied Biology, 13(2):177-188 (1926) ; Biological Abstracts, $2: 3485$ (1928).

Doudoroff, P.. "Some Recent Developments in the study of Toxic Industrial wastes," Proceedings of the $4 \mathrm{th}$ Annul Pacific. Northwest Industrial Waste Conference, Pullman, Hash. (19.52).

Drummond, R.A.. W.A. Spoor, and G.F. Olson, "Some Short-term Indicators of Sublethal Effects of Copper on Brook Trout, Salvelinus fontinalis." Journal of the Fisheries Research Board of Canada, $30(5): 698-701$ (1973).

Eaton, J.G." "Chronic Toxicity of a Copper, Cadmiun and zinc

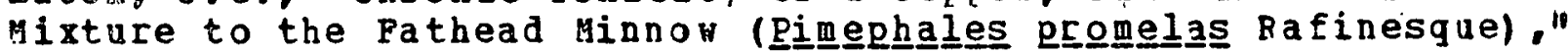
Hater Research, $7(11): 1723-1736$ (1973).

Risler, R., "Bcute Toxicities of Selected Heary Metals to the Softshell clam. ya arenarian," Bulletin of Environmental Contamination and Toxicology, 17:137 (1977).

Eisier, R, and G.R. Gardner, "Acute Toxicology to an Estuarine Teleost of Hixtures of Cadmium, Copper, and Zinc Salts," Joural of Fisb Biology, 5:131-142 (1973).

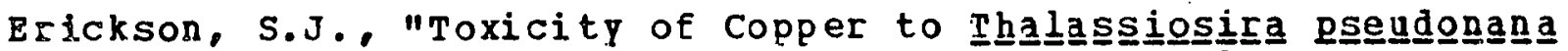
in Unenciched Inshore Seawater," Journal of Phycology. $8(4): 318-323(1972)$.

Establier, R. and E. Pascual, "Studies on Copper, Iron,

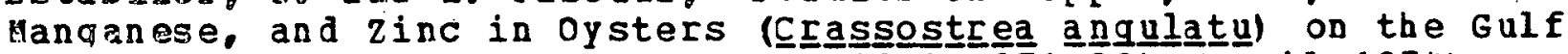
of Cadiz," Investigacion Pesquera, 38(2):371-384 (April 1974).

Federztion of Sewage and Industrial wastes associations, "Toxicisy of Copper and zinc Ions in the Dilution BOD Test," Sewaqe and Industrial wastes, $28(9): 1168-1169$ (1956).

Fielding, A.H. and G. Russell, "The Effect of Copper on Competition Between arine Alqae," Journal of Applied Ecology. 13:871 (1976).

Fingal. W. and H.M. Kaplan, "Susceptibility of Xenonous le Copper sulfate," Copeia, pp. 155-156 (1963).

Fisher, A." "Effect of Copper sulfate on Some Microorganisms in Pish Ponds," Bulletin of Pish Culture in Israel, $8(2): 21-27$ (1956). 
Fitzqerald, G.P., "Are Chemicals used in Algae control. Bioaeqradable? " Water and Sewage Norks, 122 (5):82-85 (1975).

Fitzgerald, G.P. and S.I. Falist. "Factors Affecting the Algicidal and Algistatic Properties of Copper," Applied Microbioiogy. $11(4): 345-351$ (1963)。

Poge1s. A and J.B. Sprague, "Comparative Short-Terni Tolerance of zebrafish, Fladish, and Rainbos Trout to five poisons Including potential Reference moxicants," Hater Research, 11:811 (1977).

Frazier, J.R.. "The Dynanics of Metals in the American oyster,

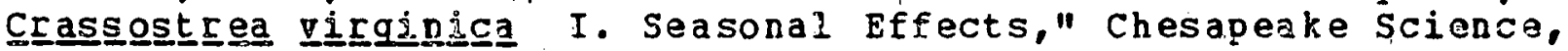
$16(3): 162-171(1975)$.

Frazier, J. H,. "The Dynamics of Metals in the American Oyster, Crassostrea vígGigica. II. Environmental Effects," Chesapeake Science, $17(3): 188-197$ (1976).

Fujiya, " Seawater on Oysters," Bioloqical Abstracts, 38:8677 (1962).

Gaechter, R.. "Heavy Metal Toxicity and Synergism to Natural Phytoplanston in the Eutrophic Lake Alpnach and the Mesotrophic Horw Bay," Schweizerische Zeitschrift fur Hydroloaie, $38(2): 97$ (1976).

Gaechter, R.. K. Lum-Shue-Chan, and L.K. Chan, "Complexing capacity of the Nutrient uedium and Its Relation to Inbibition of Algal photosynthesis by Copper," Schweizerische zeitschrift fur Hydrologie. 35:252-261 (1973).

Garảner, G.R., "Chemically Induced Lesions in Estuarine or Marine Teleosts," Pathology of Fishes, H. E. Ribelin and G. Migaki, (eds.). University of visconsin Press, Madison, pp. 657-693 $(1975)$.

Gardner, G.R. and G. Lapoche, "Copper Induced Lesions in Estuarine Teleosts," Journal of the Fisheries Research Board of Canada, 30(3):363-368(1973).

Geckler, J.P.. et al.. "Validity of Laboratory Tests for Predicting Copper Toxicity in streams," EPA-600/3-76-116, U.S. Bnvironmental Protection Agency, Duluth, Minn. (1976).

Gibson, C.E.. "The Algicidal Effect of Copper on a Green and Blue-Green Alga and Some Ecological Implications," Journal of A pplied Ecoloqy, 9:513-518 (1972).

Gibson, C.I., T.O. Thatcher, and C.V. Apts, "Some Effects of Temperature, chlorine and Copper on the Survival and Growth of the Coonstripe Shrimp. Pandalus danae," Battelle pacific Northwest I.aboratories, Bichland, Wash., BNWL-SA-5344 (1975): 
Gibson, V.R. and G.D. Grice, "Response of Macro-zooplankton Populations to Copper: Controlled Ecosystem Pollution Fxperiment," Bulletin of Marine Science, $27(1): 85-91$ (1977).

Goering, J.J., D. Boisseau, and A. Hattori, "Effects of Copper on Silicic Acid Uptake by a Marine Phytoplankton Population: Controlled Ecosystem Pollution Experiment," Bulletin of Marine science, $27(1): 58-65(1977)$.

Grande, ... "Effect of Copper and Zinc on Salmonid Fishes," Advances in vater pollution Research. Vol. I, Proceedings of the 3 rd International conference, Water pollution Control Federation, washington, D.C.. pp. 97-111 (1967).

Gross, R.E.. P. Puqno, and W.M. Dugger, "Observations on the Mechanism of Copper Damage in Chlㅡ으릴. 46:183-185 (1970).

Hannan, P.J. and C. Patouillet, "Effect of Mercury on algal Growth Rates," Biotechnology and Bloengineering, 4:93-101 (1972).

Hara, T.J.. et al.. "Effects of Mercury and Copper on olfactory Response in Rainhow Trout, Salmo gai Fisheries Research Board of Canada, 33:1568 (1976).

Hargreaves, J.H. and B.A. Whitton, "Effect of pH on Tolerance of

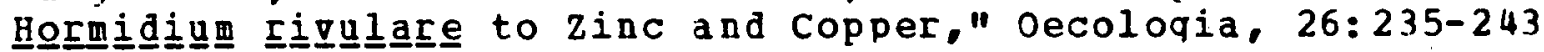
$(1976)$.

Harrison, S.E.. "Factors Influencing the Acute Toxicity of Copper Sulphate to Rainbow Trout." Canadian Fisheries and Marine Service Technical Report No. 573, Minniped, Manitoba (1975).

Harrison, H.G..R.R. Eppley, and E.H. Renqer, "Phytoplankton Nitrogen Metabolism, Nitrogen Budgets, and observations on Copper Toxicity: Controlled Ecosystem Pollution Experiment," Bulletin of Marine science, $27(1): 44-57$ (1977).

Hassall, K.A." "A Specific Effect of Copper on the Respiration of

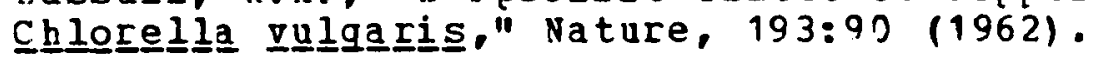

Hassall, K.A.. "Iptake of Copper and Its physiological Effect on

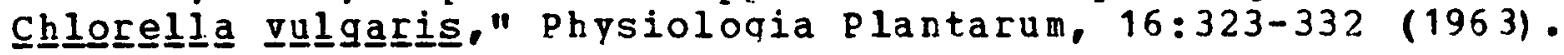

Haze1, C.R. and S.J. Meith, "Bioassay of King Salmon Eggs and SaC Fry in Copper Solutions," California Fish and Game, $56(2): 121-124$ $(1970)$.

Helz, G.R., R.J. Huggett, and J.M. Hill, "Bebavior of Mn, Fe, Cu, Zn, $C d$, and $\mathrm{Pb}$ Discharqed from a an Estuarine Environment," Water Research; 9:631-63.6 (1975). 
Herbert, D.W.M. and J.M. Vandyke, "The Toxicity to Fish of Mixtures of poisons II. Copper-Ammonia and Zinc-Phenol Mixtures," Annals of Applied Biology, 53:415-421 (1964).

Hill, C.H. and G. Matrone, "Chemical Parameters in the Study of

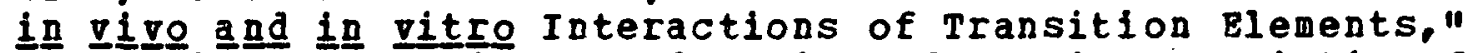
Federation proceedings. Fedaration of american societies for Experimental Biology, 29:1474-1481 (No date).

Horne, A. and C.R. Goldman. "Suppression of Nitrogen Fixation by Blue-Green Algae in a Eutrophic Lake with Trace Additions of Copper," science, 183:409-411 (1974).

Hubschman, J.H., "Effects of Copper on the crayfish orconectes rusticus (Girard) I. Acute Toxicity." Crustaceana, $12: \frac{1}{3}-4 \frac{1}{2}$ $(1967)$.

Hueck, H.J. and D. Adema, "Toxicological Investigations in an Artifical Ecosystem: A Progress Report on Copper Toxicity Toward Algae and Daphnae," Helgolaender Nissenschaftiche Meeresunt ersuchungen, 17: 188 (1968).

Hunter, W.R., "Poisoning of Harinogammarus marinus by Cupric Sulphate and Mercuric Chloride," Journal of Experimental Biology. $26(2): 113-124(1949)$.

Hutchinson, T.C., "Comparative studies of the Toxicity of Heary Metals to phytoplankton and Their synergistic Interactions," Water Pollution Research in Canada, 8:68-90 (1973).

Hutchinson, T.C. and H. Czyrska, "Heavy Metal Toxicity and synergism to Floating aquatic Needs," Verhandlungen Internationale Vereinigung fur Theoretische und Angewunde Limnologie, 19:2102-2111 (1975).

Inglis, A. and E.L. Davis, "Effects of water Hardness on the Toxicity of Several organic and Inorganic Herbicides to Fish," U.S. Bureau of sport Fisheries and nildlife Technical Paper No. 67. PD. 1-22.(1972).

Ishak, M.M. and A.M. Mohaned, "Effects of Sublethal Doses of Copper sulfate and Bayluscide on Survival and oxygen Consumpion

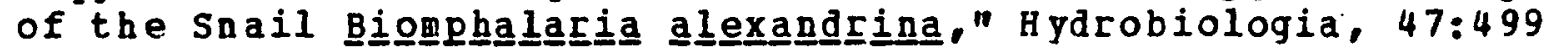
(1975).

Jackim, B.. "Influence of Lead and other Metals on Fish Delta-Aminolerulinate Dehpdrase Activity." Journal of the Fisheries Research Board of Canada, 30(4):560-562 (1973).

Jenkins, D.W., "Flow of Toxic Metals in the Environment," International conference on Environmental sensing and Assessment, Vol. I, Las Vegas, Nev. (Sept. 14-19, 1975). 
Jenne, E.A., "Controls on Mn, Fe, Co, Ni, Cu, and $\mathrm{Zn}$ Concentrations in Soils and Hater: The significant Role of Hydrous Mn and Fe oxides," Advanced Chemistry, 73:337-387 (1968).

Jones; J.R.E., "The Relative Toxicity of Salts of Lead, zinc and Copper to the Stickleback (Gasterosteus aculeatus L.) and the Effect of Calcium on the Toxicity of Lead and zinc salts," Journal of Experimental Biology. 15:394-407 (1938).

Jones, I.H.. N.V. Jones, and A.J. Radlett, "Some Effects of Salinity on the Toxicity of Copper to the Polychaete Nereis diversic의음," Fstuarine and Coastal Marine science, 4(1):107-112 $(1976)$.

Kapkor, V.T.. "Toxicity of Copper Complexes to Freshwater Mollusks," Pochvovedenie, 26 (2) (1971). (NTIS AD-763 967)

Kaplan, H. H. and L. Toh, "Toxicity of Copper for Frogs," Herpetologica, 17 (2):131-135 (1961).

Kapoor, M.N. and W. Griffiths; "The Effect of copper on the Oxygen Consumption Rates of the Stonefly Nymph, phasganophora capitata (Pictet) (Plecoptera)," Zoological Journal of the Iinnean Society, 59 (2):209-2.15 (1976).

Kerfoot, W.B. and G.A. Redmann, "Permissible Levels of Heavy Metals in secondary effluent for ose in a Combined sewage Tr eatment-Marine agriculture System II. Development of Guidelines by lethod of Additions," Proceedings of the conference on Wastewater Use in the production of Food and Fiber, oklahoma City; Okla.. pp. 79-101 (March 5-7, 1974).

Khobot'ev, V.G., V.I. Kapkov, and E.G. Rukhadze, "The Toxicity of Copper Complexes Towards scenedesmus quadriciauda Breb. " Hicrobiology (USSR), 38 (5):729-731 (1969).

Kimball; K.D., "Seasonal Fluctuations of Ionic Copper in Knights Pond, Massachusetts," Limnology and Oceanography, 18:169 (1973).

Kleer ekoper, H.. J.B. Waxman, and.J. Matis "Interaction. of Temperature and copper Ions as Orientating stimuli in tise Locomotor Behavior of the Goldfish (Carassiugs auratauㅗㄱ) "Journal of the Fisheries Research Board of Canada, $30: 725-728$ (1973).

Kleerekoper, H., et al., "Orientation of Goldfish (Ca auratus) in Besponse to a Shallow Gradient of a sublethal Concentration of copper in an Open Field," Journal of the Fisheries Research Board of Canada, 29(1):45-54 (1972).

Knauer, G.A. and J.H. Martin, "Seasonal Variations of Cadmium, Copper, Manganese. Lead, and zinc in Water and Phytoplankton in Monterey Bay. California," Limnology and Oceanography, 18 (4) 597-604 (1973). 
Lelt, P.F., et al.. "Effect of copper on some Aspects of the

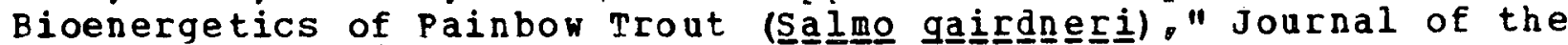
Fisheries Research Board of Canada, $33: 1335(1976)$.

Lewis, A.G., P.H. Whitfield, and A. Ramnarine, "Reduction of Copper Toxicity in a Marine Copepod by sediment Extract," Limnology and oceanography, 18(2):324-326 (1973).

Lewis, S.D. and H.M. Lewis, "Effect of Zinc and Copper on the Osmolarity of Blood serum of the channel Catfish. Ictalu punctatus Rafinesque, and Golden Shiner, Notemigonus chrysoleucas Mitchili," Transactions of the American Fisheries society, $100(4): 639-643$ (1971).

Iipschuetz, M. and A.I. Cooper, "Comparative Toxicities of Potassiun Cyanide and Potassium Cuprocyanide to the western

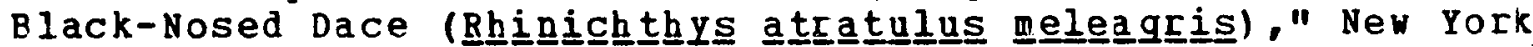
Fish and Game Journal, 2:194 (1955).

Lloyd, R., "The Toxicity of Mixtures of Zinc and Copper Sulfates to Rainbow Trout (Sal mo gair $\underline{\text { dneri }}$. Richardson)." Annals of applied Biology, 49:535-538 (1961):

Lorz, H.W, and B.P. McPherson; "Effects of Copper and Zinc on Smoltification of Coho Salmon," U.S. Fnvironmental protection Agency, EPA-600/3-77-032, Corvallis, Ore. (1977). (NTIS PB-268 3041

Lu, P., et al., "Model Ecosystem Studies of Lead and Cadmium and of Urban Sewage sludge Containing These Elements," Journal of Environmental Quality, 4:505 (1975) .

McIntosh, A.W. and N.R. Kevern, "Toxicity of Copper to Zooplankton," Journal of Environmental Quality, $3(2): 166-170$ $(1974)$.

Mackenthun, K.M. and H.I. Cooley. "Biological Effects of Copper Sulfate Treatment on Lake Ecology." Mater pollution Abstracts. $26: 8223(1953)$.

Mackereth, F.J. and W.J.P. Smyly, "Toxicity of copper in Solution to the Stone Loach," Nature, 168:1130 (1951).

Mckin, J.M. and D.A. Benoit, "Effects of Long-Term Exposures to Copper on Survival, Growth, and Feproduction of Brook Trout

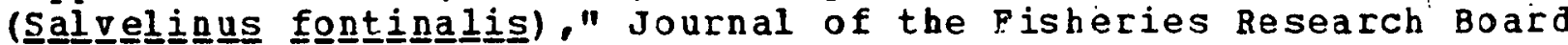
of Canada, $28(5): 655-662$ (1971).

MCKin, J.M. and D.A. Benoit, "Duration of Toxicity Tests for Establishing 'No Effect' Concentrations for Copper with Brook

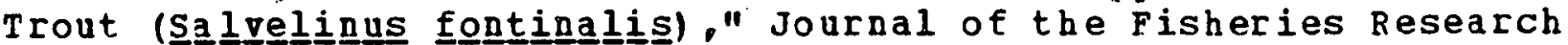
Board of Canada, $31(4): 449-452$ (1974). 
McKim, J.H., G.M. Christensen, and E.P. Hunt, "Changes in the Blood of Brook Trout (Salvelinus fontinalis) after Short-Term and Long-Term Exposure to Copper." Journal of the Pisheries Research Board of Canada, 27(10):1883-1889 (1970) .

Mclease, D.N.. "Toxicity of Copper at Two Temperatures and Three Salinities to the American Lobster (Homarus americanus of the Pisheries Research Board of Canada, 31(12):1949-1952 $(1974)$.

Mclusky, D.S. and C.N.K. Phillips; "Some Effects of Copper on the Polychaete phyllodoce ㅁacuculata," Estuarine and Coastal Marine science, $3(1): 103-108$ (1975).

Maine Department of Environaental Protection, "policy Regarding the Ise of Coppe: Compounds as Aquatic Herbicides in Maine," Report by the Division of Lakes and Bioloqical studies, augusta (Feb. 1976).

Majori, L. and F. Petronio, "Marine Pollution by Metals and Their Accumulation by Bioloqical Indicators (Accumulation Factor)," Revue Internationale d'oceanographie Medicale, 31/32:55-90 $(1973)$.

Maloney, T.E. and H. Palmer, "Toxicity of Six Chemical Compounds to Thirty Cultures of Algae," Nater Sewaqe Norks, 103(11):509-613 $(1956)$.

Mandelli. B.F., "The Inhibitory Effects of Copper on Marine phytoplankton," Contributions in Marine Science, oniversity of Texas, 14:47-57:(1969).

Marvin,.K.T., C.M. Lansford, and R.S. Wheeler, "Effects of Copper Ore on the Ecology of a Lagoon," D.S. Fish and Wildlife service, Fisheries Bulletin,: $184(61): 153-160$ (1961).

Mills. W.L.; "Water Quality Bioassay Using Selected Protozoa II. The Effects of Zinc on Population Growth of Euglena gracili Journal: of Environmental Science and Health, 11 (8 and 9):567 (1976).

Morgan. R.P.. II.. et al.. "Sublethal effects of Baltimore Harbor Water on the white perch, Morone americana, and the Hogchoker, II inectes macul latus, " Chesapeake science, 14(1):17-27 (1973).

Morris, 0.P. and G. Russell, "Effect of Chelation on Toxicity of Copper," Marine Pollution Bulletin, 4(10): 159-160 (1973).

Morry. C.J. and I.J. Cole, "Limnology and Fish Populations of Red Indian Lake, a Multi-Use Reservoir," Technical Report No. 691. Fisheries and Marine Service, Environment Canada, St. John's, Newfoundland, (1977). 
Mount, D.I., "Chronic Toxicity of Copper to Fathead Minnows (pimephales progmelas Rafinesque)," Hater Research, 2:215-223 $(1968)$.

Mount, D.I. and C.E. Stephen, "Chronic Toxicity of Copper to the

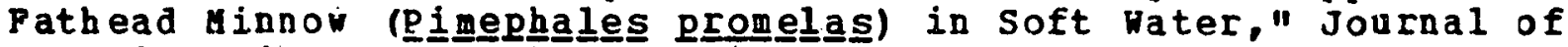
the Fisheries Research Board of Canada, $26(9): 2449-2457$ (1969).

Namminga, H.E., J.E. Scott, and S.I. Burks, "Distribution of Copper, Lead, and $\mathrm{Zinc}$ in selected conponents of a Pond Ecosystem." Proceedings of the oklahoma Academy of science, $54: 62-64(1974)$.

National Research Council, "Copper," O.S. Environmental Protection Agency, Research Triangle Park, N.C., BPA-600/1-77-003 (1977) .

Nielson, S.S., "Toxicity to Fish of Haste haters Containing Iron and Copper," Water Pollution Abstracts, Vol. 12 (1939).

Nishikawa, K. and $K$. Tabata, "Studies on the Toxicity of Heary Metals to Aquatic Animals and the Factors to Decrease the Toxicity III. On the Low Toxicity of Some Heary Hetal Complexes to Aquatic Animals." Bulletin of Tokai Regional Fisheries Research Laboratory. 58:233-241 (1969) .

O'Hara, J.. "Alterations in 02 Consumption by Bluegills Exposed to Sublethal Treatment witb Copper," Water Research, 5(6):321-327 (1971).

Okazaki, R.K.. "Copper Toxicity in the Pacific Oyster çrossostrege gigas," Bulletin of Environmental Contamination and Toxicology. $16(6): 658-664(1976)$.

Olson, R.R. and R.C. Harrel, "Effect of Salinity on acute Toxicity of lercury, Copper, and Chromium for Rangia cuneata (Pelecypoda, Mactridae)." Contributions in Marine Science, 17: $9-13$ (1973).

O'Rear, C.W.. Jr.. "Some Environmental Influences on the zinc and Copper Content of striped Bass, yorone saxatilus (Malbaum)," Ph.D. thesis, virginia Polytechnic Institute and state oniversity, Blacksburg, 70pp. (1971).

Overnell. J.: "Inhibition of Marine Algal Photosynthesis by Heavy Metals," Marine Biology. $38: 335$ (1976).

Pagenkopf, G.K., R.C. Russo, and B.V. Thurston, "Effect of Complexation on Toxicity of copper to Fishes, "Journal of the Fisheries Research Board of Canada, 31(4):462-465 (1974).

Patrick, F.M. and M. H. Loutit, "Passage of Metals in Effluents, Through Bacteria to Higher Organisms," Water Research, 10:333-335 (1976). 
Phillips, A.M., Jr.. "Reduction of the Toxicity of copper Sulphate to Pour species of Trout by the Use of Sodium chloride and Acetic Acid," Cornell Oniversity Abstracts of Theses, 1939. Ithaca, N.Y.. pp. 297-299 (1940).

Phillips, D.J.H., "Common Mussel Mytilus edulis as an Indicator of Pollution by Zinc, Cadmium, Lead, and Cooper I. Effects of Environmental variables on Uptake of Metals," Marine Biology. 38:59-69 (1976).

Pickering, $O . H$. and $C$. Henderson; "Acute Toxicity of Some Heavy Metals to Different Species of Warm Water Fishes," International Journal of Air and Water Pollution, 10:453-463 (1966).

Poon, C.P.C. and K.H. Bhayahi, "Metal Toxicity to sewage organisms," proceedings of the American Society of Civil Engineers, Journal of the Sanitary Engineering Division, Vol. 97 (1970).

Porter, K.R. and D.E. Hakanson, "Toxicity of Mine-Drainage to Embryonic and Larval Boreal Toads (Bufonidae: Buuoㅇ boㅡ르오)." Copeia, $2: 327-331$ (1976).

Rábe, F.H., R.C. Hissmar, and K.F. Winter, "Plankton Populations and Some Effects of Mine-Drainage on primary productivity of the Coeur d'Alene Biver, Delta, and Lake," University of Idaho, Hater Resources Institute Completion Report, Moscow, 20 pp. (1973). (NTIS PB-216 211)

Ray, S. and W. White, "Selected Aquatic plants as Indicator Species for Heavy. Metal Pollution," Journal of Environmental Science and Health, A-11(12):717-725 (1976).

Raymont, J.E.G. and J. Shields, "Toxicity of Copper and Chromiun in the Marine Environment," Advances in Water pollution Research, E.A. Pearson, (ed.). Macmillan, New York (1964).

Peeve, M.R.. J.C. Gamble, and M.A. Walter, "Experimental Observations on the Effects of Copper on Copepods and other zooplankton: Controlled Ecosystem Pollution Experiment, "Bulletin of Marine Science, 27 (1):92-104 (1977).

Rehwoldt, R., G. Bida, and B. Nerrie, "Acute Toxicity of Copper, Nickel and Zinc Ions to some Hudson River Fish Species," Bulletin of Environmental Contamination and Toxicology, 6(5):445-448 (1971).

Rehwoldt, R., et al.. "Effect of Increased Temperature Upon the Acute Toxicity of Some Heavy Metal Ions," Bulletin of

Environmental contamination and Toxicology, 8 (2):91-96 (1972).

Rehwoldt, R.. et al., "The Acute Toxicity of Some Heary Metal Ions Toward Benthic Orqanisns," Bulletin of Environmental

Contamination and Toxicology, 10(5):291-294 (1973). 
Reish, D.J., et al., "The Effect of Heary Metals on Laboratory Populations of Two polychaetes with Comparisons to the water Quality Conditions and Standards in Southern California Marine Waters," Water Research, 10:299-302 (1976).

Roales, R.R. and A. Perlmutter, "Toxicity of Methylmercury and Copper, applied Singly and Jointly to the Blue Gourami.

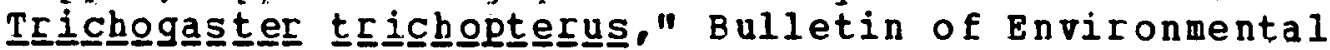
Contamination and Toxicology, 12(5):633-639 (1974).

Poales, P.R. and A. Perlmutter, "The Effects of Sub-Lethal Doses of Wethylmercury and Copper Applied Singly and Jointly, on the Immune Response of the Blue Gourami (Trichhogasten tricichopterus to Viral and Bacterial Antigens," Archives of Environmental contamination and Toxicology, 5:325-331 (1977).

Rodsaether, M.C., J. Olafsen, and J.Raa, "Copper as an

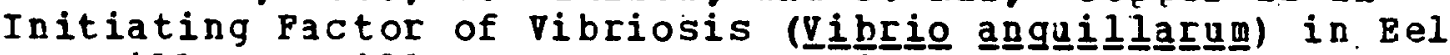
(Anguiㅣㄹㅡ angquilla a)," Journal of Fish Biology, 10:17 (1977) .

Rosco, J.J. and J.H. Rachlin, "Effects of Copper, Zinc, Cobalt, and Manganese on the Growth of the Marine Diatom Nitzchia clososteriug." Bulletin of the Torrey Botanical Club, $102: 100$ $(1975)$.

Russell, G. and O.P. Morris, "Copper Tolerance in the Marine

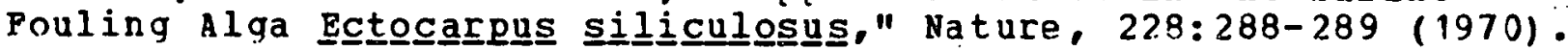

Ruthven, J.A. and J. Cairns, Jr., "Response of Fresh-1ater Protozoan Artificial Commuities to Metals," Journal of Protozoology, 20(1):127-135 (1973).

Saliba, L.J. and M. Ahsanullah, "ACclimation and Tolerance of

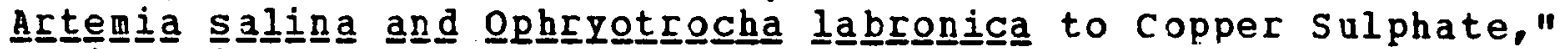
Marine Bioloqy, 23:297-302 (1973).

Saliba, L.J. and R.M. Krzyz, "Acclimation and Tolerance of

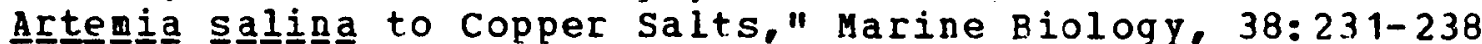
$(1976)$.

Saliba, I..J. and R.M. KIZYz, "Fffect of Heavy Metals on Hatching of Brine Shrimp Eggs," Marine Pollution Bulletin, $7(10): 181-182$ $(1976)$.

Saunders, R.L. and J.B. Sprague, "Effects of Copper-Zinc Mining Pollution on a Spawing Migration of Atlantic Salmon, "Water Research $1(6): 419-432$ (1967).

Sauter, S., et al., "Effects of Exposure to Heary Metals on Selected Preshwater Fish, Toxicity of Copper, Cadmium, Chromium and Lead to Eggs and Pry of Seven Fish species," I.S.

Enviconmental Protection Agency Report EPA-600/3-76-105, Duluth, Minn.. 75 Dp. (1976). 
Saward, D.. et al.. "Experimental studies or the Effects of Copper on a Marine Food Chain," Marine Bioloqy, 29:351-361 $(1975)$.

Scheier, A. and P. Kiry, "A Discussion of the Effects of Certain Potential Toxicants on Fish and Shellfish in the Upper Delaware Estuary," Academy of Natural Sciences of Philadelphia, Penn. (Dec. 1973). (NTIS PB-231423)

Scott, D.M. and C.W. Major, "Effect of Copper (II) on Survival,

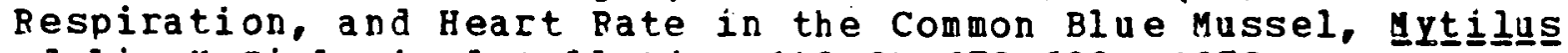
edulis.," Biological Bulletin, 143 (3):679-688 (1972).

Sellers, C.M.. A.G. Heath, and M.L. Bass, "Ihe Effect of Sublethal concentrations of copper and zinc on ventilatory Activity. Blood Oxygen and $p H$ in Rainhow Trout (Saㅡㅛㅡㅇㅡ gairg므티)." Water Research, 9:401-408 (1975).

Shav, T.L. and V.H. Brown, "The Toxicity of some Forms of copper to Rainbow Trout," Water Research, 8(6):377-382 (1974).

Shaw, H.H.R. and B. Grushkin, "The Toxicity of Metal Ions to Aquatic Orgarisms," Archives of Biochemistry and Biophysics, $67(2): 447-452$ (1957).

Smith, M. W. "Copper Sulfate and Rotenone as Fish Poisons," Transactions of the American Fisheries Society, 69:141-157 (1939).

Sodergren, S.. "Ecological Effects of Heavy Metal Discharge in a Salmon River," Drottningholm, Sweden. Institute of Freshwater Besearch, Report 55:91 (1976).

Spraque, J.B., "Avoidance of Copper-zinc Solutions by Young Salion in the Laboratory," Journal of the Hater Pollution Control Feder ation, 36:990 (1964).

Spraque, J.B.. "Lethal Concentrations of copper and zinc for Yound Atlantic Salmon," Journal of the Pisheries Research Board of Canada, 21:17-26 (1964).

Spraque, J.B.. "Effects of sublethal concentrations of $\mathrm{z}$ inc and Copper on Migration of Atlantic Salmon, "Biological problems in water Pollution. Third seminar, Cincinnati, Ohio, o.s. Public Health Service Publishing No. 999-np-25, pp. 332-333 (1965).

Sprague, J.B., "Promising anti-Pollutant: Chelating Agents NTA Protects Pish fron Copper and Zinc," Nature, 220:1345-1346 $(1968)$.

Spraque, J.B. and B.A. Ramsay, "Lethal Levels of Mixed Copper-7inc Solutions for Juvenile Salmon, "Journal of the Fisheries Research Board of Canada, 22:425 (1965). 
Sprague, J.B.; P.F. Elson, and R.L. Saunders, "Sublethal Copper-Zinc Pollution in a Salmon River - Field and Laboratory Study." International Journal of Air and Nater Pollution. $9: 531-543(1965)$.

Steemann Nielsen, E. and L.H. Bruun, "Effects of CuSO4 on the Photosynthetic Rate of Phytoplankton in Four Danish Lakes," oikos, $27: 239$ (1976).

Steemann Nielsen, E, and S. Wium-Anderson, "Copper Ions as Poison in the Sea and in Freshwater," Marine Biology, 6(2):93-97 (1970).

Steemann Nielsen, E. and S. Wium-Anderson, "Influence of Copper on Photosynthesis and Growth of Diatoms," Physiologia Plantarum. $24: 480-484(1971)$.

Steemann Nielsen, E.. I. Kamp-Nielsen, and S. Wium-Anderson, "The Effects of Deleterious Concentrations of Copper on the

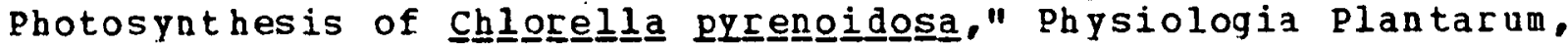
22:1121-1133 (1969).

Stokes, P.M., "Uptake and Accumulation of. Copper and Nickel by Metal-Tolerant strains of scenedes $\underline{\text { su}} \underline{\text { s. }}$. " Verhandlungen

Internationale vereinigung fur Theoretische und Angewandte Limnologie, 19:2128-2137 (1975).

Stokes, P.M., "Adaptation of Green Alqae to High Levels of Copper and Nickel in Aquatic Environments," International Conference on Heavy Metals in the Environnent, Vol. II. Pathways and Cycling, Institute of Environmental Studies, Oniversity of Toronto, 137 $(1977)$.

Sudo, R. and S. Aiba, "Fffect of Copper and Hexavalent Chromium on the Specific Growth Rate of Ciliata Isolated from Activated-Sludge," Water Research, 7(9):1301-1307 (1973).

Sunda, W. and R.I. Guillard, "The Relationship Between Cupric Ion Activity and the Toxicity of copper to Phytoplankton," Journal of Marine Research, 34:511 (1976).

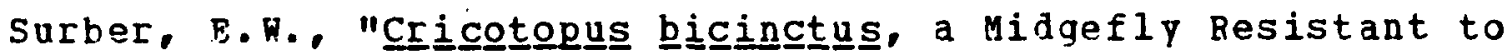
Electroplating Wastes," Transactions of the a merican Fisheries society, 88(2):111-116 (1959); Biological Abstracts, 35:9533 $(1960)$.

rabata, K.. "Studies on the Toxicity of Heary Metals to Aquatic Arimals and the Factors to Decrease the Toxicity $I$. On the Formation and the Toxicity of Precipitates of Heavy letals," Bulletin of Tokai Reqional Pisheries Research Laboratory, 58:203-214 (1969). 
Tabata, K.. "Studies on the Toxicity of Heary Metals to Aquatic Animals and the Factors to Decrease the roxicity II.

Antagonistic Action of Hardness components in Nater on the Toxicity of Heavy Metal Ions," Bulletin of Tokai Regional Fisheries Research Laboratory, 58:215-232 (1969).

Tabata. K.. "Studies on the Toxicity of Heavy Metals to Aquatic Animals and the Factors to Decrease the Toxicity IV. on the Relation Between the Toxicity of Heavy Metals and the Quality of Environmental Water," Bulletin of Tokai Regional Fisheries Research Laboratory, 58:243-253 (1969).

Thomas, W.H. and D.L.K. Seibert, "Effects of Copper on the Dominance and Diversity of Algae: Controlled Ecosystem Pollution Experiment," Bulletin of Marine Science, 27:23 (1977).

Thomas, W.H., et al.. "Effects of copper on Phytoplankton Standing crop and Productivity: Controlled Ecosystem pollution Experiment," Bulletin of Marine science, 27(1):34-43 (1977).

Thurberg, F.P., M.A. Dawson, and R.S. Collier, "Effects of Copper and Cadmium on nsmoregulation and oxygen Consumption in Two Species of Estuarine Crabs," Marine Biology, 23:171-175 (1973).

Trollope, D.R. and B. Evans, "Concentrations of Copper, Iron, Lead. Nickel and zinc in Freshwater algal Blooms," Environmental Pollution, 11:109-116 (1976).

Turnbul1-kemp. P. St. J.. "Trout in Southern Rhodesia v. On the Toxicity of Copper Sulfate to Trout," Rhodesia aqricultural Journal, 55(6):637-640 (1958).

U.S. Department of the Interior, "Copper in water - A Bibliography." office of Water Resources Research Report WRSIC 71-204, 189 pP. (July 1971). (NTIS PB 201260 )

Vaccaro; R.F., et al.. "Response of Natural Marine Bacterial Populations to Copper: Controlled Ecosystem pollution Experiment," Bulletin of Harine Science, 27:17 (1977) .

Van Loon, J.C. and R.J. Beamish, "Heary Metal Contamination by Atmospheric Fallout of sereral Flin flon Area iakes and the Relation to Fish. Populations," Journal of the Fisheries Research Board of Canada, 34:899 (1977).

Vinikour, N.S., "Concentrations of zinc, Copper, Cadmium, and lead in. Selected Fish species of the Fox River from Locations with Varying Potential Metal Inputs," M.S. thesis, Northern Illinois oniversity. DeKalb, 103 pp. (Dec. 1977).

Naiwood, K.G.. "Effects of Copper; Hardness and pH on Swiming Performance and Growth of Rainbow Trout (Sal mo gairranerin)." Dissertations Abstracts, 38 (1977). 
Malker, J.B.. "Inorganic Micronutrient Requirements of Chlo으르늠. I. Requirements for Calcium (or Strontium). Copper, and Molybdenum," Archives of Biochemistry and Biophysics, 46:1-11 (1953).

Whitton, B.A.. "Toxicity of Heavy Metals to Freshuater Algae: A Beriew," Phykos, $9(2): 116-125$ (1970).

Whitton, B.A., "Toxicity of zinc, Copper, and Lead to Chlorophyta fron Flowing Naters," Archiv fuer Mikrobiologie, 72:353-360 $(1970)$.

MIldish, D.J..W.G. Carson, and W.V. Carson, "The Effect of Humic Substances on Copper and zinc Toxicity to Salmon, sal 1 mo sala L.." Journal of the Fisheries Research Board of Canada, hS Report 1160,8 pp. (1971).

Milson, R.C.H.. "Prediction of Copper Toxicity in Receiving Daters," Journal of the Fisheries Research Board of Canada, $29(10): 1500-1502(1972)$.

Winner, R.W.. "Toxicity of Copper to Daphnids in Reconstituted and Natural Waters," O.S. Environmental Protection Agency Report EPA-600/3-76/051(1976).

Winner, R.W. and M.P. Farrell, "Acute and Chronic Toxicity of Copper to Four Species of Daphnia," Journal of the Fisheries Research Board of Canada, 33:1685 (1976).

Winner, R.W., et al.. "Response of the Macroinvertebrate Fauna to a Copper Gradient in an Experimentally Pollated stream"

Verhandlungen Internationale Vereinigung fur Theoretische and Angewandte Limnologie. 19:2121 (1975).

Winner, R.W., et al., "Effect of Food Type on the acute and Chronic Toxicity of Copper to Daphngia magnan, "Freshwater Biology. $7: 343(1977)$.

Wisely, B. and R.A.P. Blick, "Mortality of Marine Invertebrate Larvae in Mercury, Copper, and Zinc Solutions," Australian Journal of Marine and Freshwater Research, $18(1): 63-72$ (1967).

Young. R.G. and D.J. Lisk, "Effect of Copper and Silver Ions on Algae," Journal of the Nater Pollution Control Federation, $44(8): 1643-1647$ (1972).

Zitko, V. and W.G. Carson. "A Mechanism of the Effects of Hater Hardness on the Lethality of Heavy Metals to Fish," Chemosphere, 5:299-303 (1976).

Zitko, V.. W.V. Carson, and .G. Carson, "prediction of Incipient Lethal Levels of Copper to Juvenile Atlantic Salmon in the Presence of Humic Acid by Cupric Electrode," Bulletin of Environmental Contamination and Toxicology, $10(6): 265-271$ (1973). 
CYANIDE

Bridges, W.R.. "Sodium Cyanide as a Fish Poison," O.S. Fish and Wildife Service, Special Scientific Peport--Fisheries, No. 253, $11 \mathrm{pp}$. (1958).

Broderius, S.J.; "Determination of Molecular Hydrocyanic Acid in water and studies of the Chemistry and Toxicity to Fish of the Nickelocyanide.complex," M.S. thesis, oregon state oniversity. corvalis (1970).

Brown. V.M. "The Calculation of the Acute roxicity of uixtures of Poison to Rainbow Trout," Water Research, 2(10):723-733

$(1968)$.

Burdick, G.E. and M. Lipschuetz, "Toxicity of Perro and Ferricyanide Solutions to Fish and Deternination of the cause of Mortality." Transactions of the American Fisheries society. $78: 192-202$ (1948).

Burdick, G.E., et al.. "Toxicity of Cyanide to Brown Trout and Smallmouth Bass," New: York Pish and Game Journal, 5:133 (1958).

Cairns, J..J Jr. and A. Scheier, "Environmental Effects Opon Cyanide Toxicity to Fish," Notulae Naturae, 361, 11 pp. (1963).

Clauqh, G.W., "Poi soning of Animals by Cyanides Present in some Industrial Effluents," Mater Pollution abstracts, Vol. 7 (1934).

Costa, H.H.." "Responses of Freshwater Animals to sodium Cyanide Solutions," Ceylon Journal of Sciences, Blological sciences, 5:41 (1965).

Czensky, R., "Hydrocyanic acid, Its Occurrence, Detection, and Bffect in streams," Water Pollution Abstracts, 25(4):26 (1952).

Doudoroff, P.. "Some Experiments on the Toxicity of complex Cyanides to Fish," Sevage and Industrial wastes, 28:1020 (1956).

Doudoroff, P.. "Toxicity to Fish of Cyanides and Related Compounds, A Review," U.S. Environmental Protection Agency, Ecoloqical Research Series Report ERA-600/3-76/038, 155 pP. $(1976)$.

Doudoroff, R.. G. Luduc, and C.R. Schneider, "Acute Toxicity to Fish of Solutions Containing. Complex Metal Cyanides, in Relation to Concentrations of Molecular Hydrocyanic Acid," Transactions of the American Fisheries Society, 95(1):6-22 (1966).

Downing, K.M., "Influence of Dissolved oxpgen on the Toxicity of Potassium cyanide to Rainbow Trout," Journal of Experimental Biology, 31:161 (1954). 
Henderson, C., et al.. "Effect of Some organic Cyanides (Nitriles) on Fish," proceedings of the 15th Industrial Waste Conference (1960). Bngineering Bulletin of Purdue University. $45(2): 120-130(1961)$.

Herbert, D.H.M. and R. Downing, "A Further study of the Toxicity of Potassium Cyanide to Rainbow Trout (Salmo gair Richardson)," Annals of Applied Bioloqy, 43:237 (1955).

Herbert, D.W.M. and J.C. Merkens, "Toxicity of Potassium Cyanide to Prout," Journal of Experimental Biology, $29: 532$ (1952).

Karsten, A." "Investigation of the Effect of Cyanide on Black Hills Trout," Black Hills Engineer, 22:145 (1934).

Koenst, M.M.. et al.. "Effect of Chronic Exposure of Brook Trout to Sublethal Concentrations of Hydrogen Cyanide," Environmental Science and Technoloqy. 11:883 (1977).

Leduc, G.. "Some Physiological and Biochemical Responses of Rish to Chronic Poisoning by Cyanide," Ph.D thesis, Oregon state Iniversity. Corvallis (1966).

Lehmann, C., "Effects on Fish of Effluents Containing Cyanide," Journal of the American Water Works Association, 22:998 (1930).

Lind, D.T., L.L. Smith, Jr., and S.J. Broderius, "Chronic Effects of Hydrogen Cyanide on the Pathead Minnow," Journal of the Hater Pollution Control Federation, $49(2): 262-268$ (1977).

Lipschuetz, and A.I. Cooper, "Comparative Toxicities of Potassium Cyanide and Potassium Cuprocyanide to the Hestern

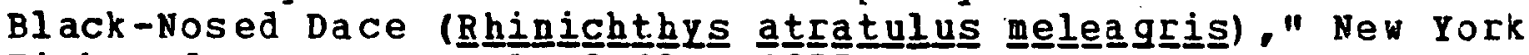
Fish and Game Journal, 2:194 (1955).

Malacea, I., "Contributions to the Rnowledge of Toxic Effects of Cyanides, Ammonia. Mercury, and Arsenic on Some Fish species and on Dạphñía," studii de Protectia di Epurarea Apelor, 7:751-792 $(1966)$.

Neil, J.H.. "Toxicity of Cyanides to Fish," Presented at the $3 r d$ Ontario Industrial naste conference, Toronto (1956).

Neil, J.H., "Some Effects of Potassium Cyanide on Speckled Trout

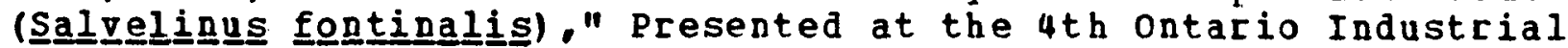
waste conference, Toronto (1957).

Pace, E. and B. McCashland, "Effects of Low Concentrations of Cyanide on Growth and Respiration in Pelom wilson," proceedings of the society for Experimental Biology and Medicine, 76:165 (1951). 
Silaichuk, E.V. the effects of waste haters containing Cyanides and Hexaralent Chromium on the viability of Certain Aquatic organisms." Gigiena i Sanitariya, 34:78-79 (1969).

Smith, R.T., "Cyanide Bearing Ore Mill Refuse as a Menace to Fish Life." Sciẹce, 87:552 (1938).

southqate, C.A. inet al. "Toxicity of Trout to Potassium Cyanide and p-cesol in water containing Different concentrations of Dissolied 02, "Biochemical Journal, 27:983-985 (1933).

Surber, Eon., "Cricotopus bicingctus, a Midgefly Resistant to Electroplating Mastes " Transactions of the American Pisheries Society, $88(2): 111-116$ (19.59); Biological Abstracts, $35: 9533$ (1960).

Tupholme, C.H.S. "Death of Fish fron Cyanides in coke oven Effluents, industrial and engineering Chemistry, News Edition, $11: 211(1973)$.

Water Pollution Research Laboratory, Stevenage, England, "Fish and Mater Quality Criteria," Notes on Nater Pollution, No. 65 (June 1974).

Wuhrmann, K. and H. Hoker, "Toxicology of Fish IT. Experimental Investigations on the Toxicity of Amonia and cyanide," Bioloqical abstracts, 25:3960 (1951).

Zehmpfening, R.G., "Possible Toxic Effects of Cyanates, Thiocyanates, Ferricyanates, Perrocyanides and Chromates Discharged to surface Nater," Proceedings of the 22 nd Industrial Waste Conference, Engineering Bulletin of purdue oniversity. 52 (3) : 879-883 (July 1968).

\section{DISSOIVED SOLIDS - SALINITY}

Ategg, R. Msome Implications from the Changes of the Hucous covering of Fish subjected to salt Solutions," proceedings of the Louisiana Academy of Sciences, 12:7-1n (1949).

Abegq, R. " "Some Effects of Inorganic Salts on the Blood specific Gravity and Tissue Fluids of the Bluegill, Lepomis maccrochírus Raf.," Physioloqical zoology, 23:124 (1950).

Adelman, I.R., I.I. Smith, Jr., and G.D. Siesennop, "Acute Toxicity of Sodium chloride, Pentachlorophenol, Gutbion, and Hexaralent Chromium to Fathead Minnows (Pinephales pronelass) and Goldfish (Carassius auratus) " Journal of the Fisheries Research Boar d of Canada, $33(2): 203-208$ (1976): 
Anderson, B.G.. "Toxicity Thresholds of Various Sodium Salts

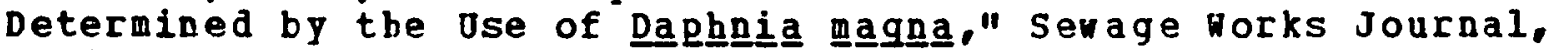
$18: 82(1946)$.

Andrew, R.R.. K.E. Biesinger, and G.E. Glass, "Bffects of Inorganic Complexing on the Toxicity of Copper to Dạphngia magqua.." vater Research, 11:309-315 (1977).

Biebl, R. and C.P. McRoy, "Rlasmatic Resistance and Rate of Respiration and Photosynthesis of Zostera maiㅡ믐 at Different Salinities and Tenperatures," Marine Biology, 8:48 (1971).

Binet, L. and P. Nicolle, "Influence of the Salinity of the Ambient Hedium on the Toxicity of Mercuric chloride for the Stickleback," Water Pollution Abstracts, Vol. 15 (Jan. 1942).

Bodine, J.H.. "Action of Sodium, Potassium, and Calcium Chlorides on the Egg of Fundulus," Proceedings of the National academy of Sciences of the 0.S.A.. 13:698-699 (1927).

Bodine, J.H.. "Action of Salts on Fundulus Egg I. Action of Na, $K$, and Ca Chlorides Upon the Egg of Funduuuㅗ. "Biological Bulletin, 54:396-404 (1928).

Brown, V.M.; "The Calculation of the Acute roxicity of Mixtures of Poison to Rainbow Trout," Water Research, 2(10):723-733 (1968).

Brown, V.M., D.G. Shurben, and J.K: Fawell, "Acute Toxicity of Phenol to Rainbow Trout in Saline Waters," Mater Research, $1: 683-685(1967)$.

Brungs, M.A.. et a 1." "Bffects of Pollution on Freshwater Fish," Journal of the Water pollution Control Pederation, $49(6): 1425-1493$ (1977).

Charnot, A., "Effect of Certain Mineral Compounds on the Toxicity of Calcium Fluoride," Journal of the American Nater Norks Association, 31:1081 (1939).

Clemens, H.P. and J.C. Finnell, "Biological Conditions in a Brine-Polluted Stream in Oklahoma," Transactions of the American Fisheries Society. 85:18 (1955).

Clemens, H.P. and W.H. Jones, "Toxicity of Brine Water from $0 i l$ Wells," Transactions of the American Fisheries Society, 84:97 (1954).

Davenport, J.. "A Study of the Effects of Copper Applied Continuously and Discontinuously to specimens of Mytilus edulis (L.) Exposed to steady and Fluctuating Salinity Levels," Journal of the Marine Biological Association, 57:63 (1977). 
Davies, P.H., "Need to Establish Heavy Metal standards on the Rasis of Dissolved Metals," Proceedings of the International Joint Commission's Norkshop on Toxicity to Biota of letal porms in Natural Nater, October 7-8, 1975, Duluth, Minn. (April 1976).

Dowden, B.F., "Cumulative Toxicities of certain Inorganic Salts

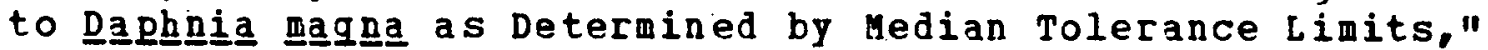
proceedings of the Louisiana Academy of science, 23:77-85 (1960).

Fairchild, E.J., "Low Dissolved oxygen: Effect opon the Toxicity of Certain Inorganic Salts to the Aquatic Invertebrate Daphnhia nagnă." Louisiana state Oniversity Engineering Research Bulletin, Baton Bouge, 51:95-102 (1955).

Frabm, J.P., "Toxicity Tolerance studies Utilizing Periphyton (Toxitoleranzversuche an Hassermoosen)." Gewasser und abwasser, 57/58:59-66 (1975)。

Garrev, W.C., "Resistance of Presh-Water Fish to Changes of osmotic and Chemical Conditions," American Journal of Physiology, $39: 313(1916)$.

Herbert, D.W.M. and D.S. Shurben, "The Susceptibility of Salionid Fish to Poisons under Estuarine Conditions - II. Ammonium Chloride," International Journal of Air and Water Pollution 9:89-91 (1965).

Hodgson. E.S.. "Reaction Thresholds of an Aquatic Beetle Lacccophil us máculolosis to Salts and Alcohols," Physiological Zooloqy, $24: 131$ (1951).

Houston, A.H.. "Osmorequlatory Adaptation of steelhead Trout

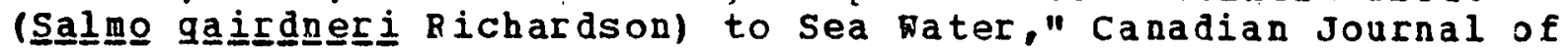
zoology, $37: 729-748$ (1959).

Jones, M.B.." "synergistic Effects of salinity, Temperature, and Heavy Metals on Mortality ad osmoregulation in Marine and Estuarine Isopods (Crustacea)." Marine Biology, 30:13 (1975).

Karpevich, A.P. and A.T. Shurin, "Effect of Different Salinities and Manqanese Ion on the Survival Respiration of the Baltic Flounder [ le leur Riqa," Journa if Ichthyology, 5:753-763 (1973).

Keckes, S. and J.K. Miettinen, "A Review of Mercury as a Marine pollutant," FAO Technical Conference on Marine pollution and its Fffects on Living Resources ard Fishing, Food and Agriculture organization, Rome (Dec. 9-18, 1970).

Keeney, D.R., "Fate of Nitrogen in Aquatic Rcosystems," Eutrophication Information Prooran. Iiterature Reviev No. 3. University of Wisconsin Hater Eesource Center, Madison (1972). (NTIS PB-209 217) 
Kleerekoper, H., et al.. "Orientation of Goldfish (Ca auratus) in Response to a Shallow Gradient of a sublethal Concentration of copper in an Open Field," Journal of the Fisheries Research Board of Canada, 29(1):45-54 (1972).

Iansing, A.I.. "Sone Ef fects of Hydrogen Ion Concentration, Total Salt concentration, Calcium and citrate on Longevity and Pecundity of the Rotifer," Journal of Experimental Zoology. $92: 195-212(1942)$.

McGahee, C.F. and G.J. Davis, "Photosynthesis and Respiration in Myriophylluuㅡ spicatum L. as Related to Salinity," Limnology and oceanography. 16:826-829 (1971).

Mckim, J.M., et al.. "Effects of Pollution on Freshwater Fish," Journal of the Water Pollution Control Federation. $45(6): 1370-1407$ (June 1973).

Mclease, D.H.. "Toxicity of Copper at Two Temperatures and Three

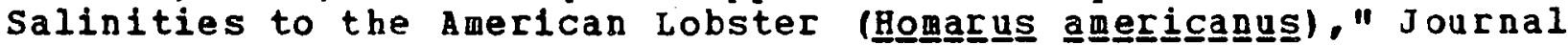
of the Fisheries Research Board of Canada, 31(12):1949-1952 $(1974)$.

Gyers, V.B., R.L. Iverson, and R.C. Harriss, "The Effect of Salinity and Dissolved Organic Matter on Surface Charge Characteristics of Some Euryhaline Phytoplankton," Journal of Experimental Marine Biology and Ecology, 17:59-68 (1975).

Neel, J.K.. "Biotic Character as Related to stream Mineral Content," Transactions of the American Microscopical society, $92(3): 404-415$ (1973).

O'Hara, J., "Cadmium Optake by Fiddler Crabs Exposed to Temperature and Salinity Stress," Journal of the Fisheries Research Board of Canada 30:846-848 (1973).

O'Hara, J.. "Influence of Temperature and Salinity on the Toxicity of Cadmium to the Fiddler Crab, ㅁa pagiliategr." Fisheries Bulletin, 71(1):149-153 (1973).

Olson, R.R. and R.C. Harrel, "Effect of Salinity on acute Toxicity of Mercury. Copper, and Chromium for Rangia canneanta (Pelecypoda, Mactridae)," Contributions in Marine Science, $17: 9-13$ (1973).

Pagenkopf, G.K., R.C. Russo, and R.V. Thurston, "Effect of Complexation on Toxicity of copper to Fishes," Journal of the Fisheries Research Board of Canada, 31:462-465 (1974).

Phillips, A.M.. Jr., "Reduction of the Toxicity of Copper Sulphate to Four Species of Trout by the Jse of sodiun Chloride and Acetic Acid," Cornell University abstracts of Theses, 1939. Ithaca, N.Y.. pp. 297-299 (1940). 
Phillips, A.M., Jr.. "The Physiological Effect of Sodiul Chloride Upon Brook Trout," Transactions of the American Fisheries society. 74:297-309 (1944).

Phillips, D.J.H.. "Effects of Salinity on the Net optake of zinc

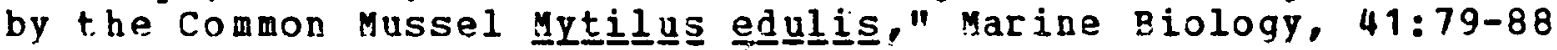
$(1977)$.

Pollard, C.B., "physiological Effects of Mineral salts in Natural waters," Journal of the American Water Norks Association, 28:1038 $(1936)$.

Powers, E.B.. "Influence of Temperature and concentration on the Toxicity of Salts to Pishes," Ecology, 1:95-111 (192)).

Powers, E.B., "A Comparison of the Electrical Conductance of Electrolytes and their Toxicities to Fish," American Journal of Physiology, 55:197-200 (1921).

Raymont, J.E.G. and J. Shields, "Toxicity of Copper and Chromiun in the Marine Environment;" Advances in Water Pollution Research, E.A. Pearson, (ed.), Macmillan, New York (1964).

Roberts, B.A. and E.C. Ja, "Beport No. 38 on the Influence of Common Salt on Freshwater Fish, Being an Bccount of Experiments Carried out at the Pisheries Experiment Station. Alresford, New Hampshire," Salmon and Trout Magazine, 32:129-135 (1923).

Rosenberg, R. and J.D. Costlow, Jr.. "Synergistic effects of Cadmium and Salinity Combined with Constant and Cycling Temperatures on the Larval Development of Tro Estuarine Crab Species," Marine Biology, 38:291 (1976).

Scheuring, L.. "Experiments on the Action of $N a 2 s 04$ on Fish and Other Water Orqanisms," Biological Abstracts, 25:26463 (1951); Nater Pollution Abstracts, $27(8): 191$ (1952).

Schmidt-Nielsen, B.. "Osmorequlation: Effect of Salinity and Heavy Metals," Proceedings of the American. Society of Experimental Biology, $33(5): 2137-2146$ (1974).

Seifriz, W.." "Toxicity and the Chemical Properties of Ions," Science, 110:193-196 (1949).

Shumay, S.E.. "Effect of Salinity Pluctuation on the osmotic Pressure and $\mathrm{Nat}, \mathrm{Ca} 2+$ and $q 2+$ Ion Concentrations in the Hemolymph of Bivalve Molluscs," Marine Biology, 41:153-177 $(1977)$.

Sinqh, S.B., S.C. Banerjee, anit P.C. Chakrabarti, "preliminary observations on Response cf Young Ones of Chinese Carps to various physico-Chemical Fastors of Water, "Proceedings of the National Academy of sciences, India, 37 (111):320-324 (1967). 
Smith, M.M. and J.R. Saunders, "Movements of Brook Trout,

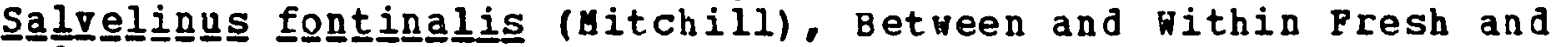
Salt Water," Journal of the Fisheries Research Board of Canada, $15(6): 1403-1449$ (1958).

Styron, C.E., et al.. "Effects of Temperature and Salinity on Growth and Optake of Zn65 and Cs137 for Six Marine Algae," Journal of the Marine Biological Assoclation of the onited Kingdon, 56:13-20 (1976).

Teeter, J.W., "Effects of Sodium Chloride on the Sago Pondweed," Journal of Wildlife Management, 29:838-845 (1965).

Thurberg, F.P.. A. Calabrese, and M.A. Dawson, "Effects of Silver on Oxygen Consumption of Bivalves at Various Salinities," Pollution and Physiology of Organisms, F.J. Vernberg and . B. Vernberg, (eds.). Academic Press, New York, pp. 67-78 (1974).

Trama, F.B.. "Acute Toxicity of Some common salts of Sodium, Potassium, and Calcium to the Common Blueaill (Lepomis macrochirus Raf.) ." Proceedings of the Acadeng of Natural Sciences of Philadelphia, 106:185-205 (1954).

Van Winkle, H.. Jr. "The Effects of Season, Temperature and Salinity on the oxygen Consumption of Bivalve Gill Tissue," Comparative Biochemistry and Physiology, 26:69-80 (1968).

Vernberg. H.B.." "Synergistic Effects of Temperature, Salinity, and Mercury on Survival and Metaboliso of the Adult Fiddler Crab, 므르 pugilatator," Fisheries Bulletin, 70:415-420 (1972).

Vernberg, N.B. and J. O'Hara, "Tenperature-Salinity Stress and Mercury optake in the Fiddler Crab, Uca pugilatoror," Journal of the Pisheries Research Board of Canada, 29(10):1491-1494 (1972).

Veselor. E.A.. "Influence of Salinity of the Extra Medium on the Intensity of Respiration of Fish," Zoologicheskii Zhurnal, $28(1): 85-98(1949)$.

Von Nesternhagen, H.; H. Rosenthal, and K.R. Sperling, "Combined Effects of Cadmium and Salinity on Development and Survival of Herring Bggs," Helgolaender Bissenschaftliche Meeresunt ersuchungen, 26:416-433 (1974).

Nater Pollution Research Laboratory, Stevenage, England, "Fish and Water Quality Criteria," Notes on Nater Pollution, No. 65 (June 1974).

Nells, M. H., "Reactions and Resistance of Fishes in Their Natural Environments to Salts," Journal of Experimental Zoology. 19:243-283 (1915). 
Whitfield, A.K. and S.J.M. Blaber, "Effects of Temperature and

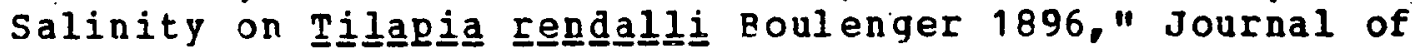
Fisheries Biology. 9:99(1976).

Wiebe, A.H., J.G. Burr, and H.E. Faubin, "Problem of Stream Pollution in Texas with special Reference to salt pater from oil Fields," Transactions of the American Fisheries Society, 64:81 (1934).

Young, R.T., "Resistance of Fish to Salts and Alkalinity." American Journal of Physiology, 63:373 (1923).

\section{FLUORIDE}

Angeloric, J.H.. W.F. Sigler, and J.H. Neuhold, "Eefects of Temperature on the Incidence of Fluorosis in Rainbow Trout," Proceedings of the $15 \mathrm{th}$ Industrial Nastes Conference, Purdue Engineering Bulletin, 45(2):496-507 (1961).

Angelovic, J.W., W.F. Siqler, and J.H. Neuhold, "Temperature and Fluorosis in Rainbow Trout," Journal of the Nater Pollution control Federation, $33(4): 371-381$ (1961).

Brinamann, G. and R. Kuhn, "The Toxic Effects of raste Water oa Aquatic Bacteria. Alqae, ani Small Crustaceans," Gesundheits-Ingenieur, 80:115 (1959) .

Charnot, A.. "effect of Certain Mineral Compounds on the Toxicity of Calcium Fluoride," Journal of the American Nater Morks Association, 31:1081 (1939).

deroos, C.D.. "The Effects of Sodium Fluoride on the reight Gain and Gills of the Common Goldfish," M.S. thesis, Utah state oniversity. Logan, 40 pp. (1957).

Groth, E.. III., "An Evaluation of the Potential for Ecological Damage by Chronic, Low-Level Environmental pollution by Pluoride," Fluoride, 8:224-240 (1975).

Hemens, J. and R.J. Marwick, "Effects of Fluoride on Estuarine organisms," Water Research, 6:1301-1308 (1971).

Hemens, J.. R.J. Warwick, and W.D. Oliff, "Effect of Extended Fxposure to Low Fluoride Concentration on Estuarine Fish and crustacea," water Pollution Research Proceedinqs, S.H. Jenkins, (ed.l. Pergamon. New York, pp. 579-585 (1975): Progress in water Technology, $7(3 / 4): 579-585$ (1975).

Herbert, D.W.M. and D.S. Shurben, "Toxicity of Fluoride to Rainhow Trout," Water and. Niste Ireatment Journal, 10:141-142 $(1964)$. 
Maynard, E.A., M.L. Downa, and M.F. LaSher, "Occurrence and Bioloqical Effects of Fluorine compounds," Annotated Bibliography, Kettering Laboratory, Oniversity of Cincinnati, Ohio $(1958)$.

Neff, A." "The Effect, of Fluorine in Natural waters on the Teeth of Small Fish," Science. 82:301 (1935)...

Neuhold, J.M. and W.F. Sigler, "Fffects of sodium Fluoride on Carp and Rainbow Trout," Transactions of the American Fisheries society, $89(4): 358-370$ (196)).

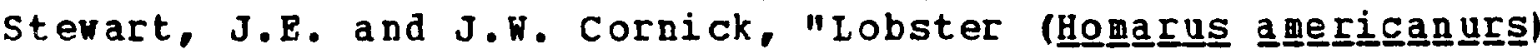
Tolerance for Tris Buffer, Sodium Fluoride, and Seawater Extracts of Various Hoods," Journal of the Fisheries Research Board of Canada, $21(6): 1549-1557$ (1964).

Wallen, I.E., W.C. Greer, and R. Lasater, "Toxicity to Gambuuㅗaㅡ affinis of Certain Pure Chemicals in Turbid Waters," Sewage and Industrial Wastes, 29 (66):695-711 (1957).

Wrigbt, D.A., "Toxicity of Pluoride to Brown Trout Fry (ㅁa므o truttal)." Environmental Pollution, 12:57-62 (1977).

\section{HARDNESS (TOTAL)}

Brkovic-poporic, I. and M. Popovic, "Effects of Heavy vetals on Survival and Respiration Rate of Tubificid Worms: Part I Effects on Survival," Environmental Pollution, 13:65-72 (1977).

Brkovic-poporic, I. and M. Popovic, "Effects of Heavy Metals on Survival and Respiration Rate of Tubificid Norms: Part II Effects on Respiration Rate," Environmental Pollution, 13:93-98 (1977).

Brown: V.M.." The Calculation of the Acute Toxicity of Mixtures of Poison to Rainbow Trout," Hater Research, $2(10): 723-7.33$ $(1968)$.

Brown, V.M." "Aspects of Heary Metals Toxicity in Fresh Waters," Proceedings of the International Joint Commission's Workshop on Toxicity to Biota of Metal Porms in Natural water, october 7-8, 1975. Duluth, Minn.. pp. 59-75 (April 1976)...

Brown, V.M.. D.H.M. Jordan, and B.A. Tiller, "Effect of Temperature on the Acute Toxicity of Phenol to Rainbow Trout in Hard Nater," Water Research, 1:587-594 (1967). 
Cairns, J., Jr. and A: Scheier, "Bffects of Temperature and Hardness of later. Opon the Toxicity of zinc to the Common Blueqill (Leponis macrochirus Rafinesque)." Notulae Naturae, 299:12 (1957).

Cairns, J.. Jr. and A. Scheier. "The Effects of Temperature and Hardness of Water opon the Toxicity of zinc to the Pond snail, Physa het e므오통pha (Say)," Notulae Naturae, 308:1-11 (1958) •

Cairns, J.. Jr. and A. Scheier, "The Effects of Tenperature and Hardness of Hater Jpon the Toxicity of Potassium Dichromate to the Comon Blueqill Sunfish," Transactions of the Northeastern nildife Conference, 10 th annual Meeting, Montreal, pp. 86-98 (Jan. 4-7, 1958).

Chapman. G., "Effect of Heavy Metals on Fish," Oregon State University Water Resources Research Report No. SEMN-RR-D16.73. pp. 141-162 (Jan. 1973).

Charnot, A.. "Effect of Certain uineral compounds on the Toxicity of Calcium Fluoride," Journal of the American Nater Horks Association, 31:1081 (1939).

Cook, R.H.. R.A.W. Hoos, and R.P. Cote; "Toxicity of copper and zinc to atlantic Salmon; Laboratory and Field Evaluations with Special Buphasis on Hiqh Nater Hardness Concentrations," Canadian Research and Development Branch. MS Report 71-16, 88 pp. (1971).

Cote, R.P.. "Hardness as a Modifying Factor in Heavy Metal Toxicity," Canadian Research and Development Branch, uS Report $71-18,23$ pp. (1971).

Davies, P.H.. "Need to Establish Heavy Metal standards on the Basis of Dissolved Metals," Proceedings of the International Joint Commission's Horkshop on Toxicity to Biota of Metal porms in Natural Hater, October, 7-8, 1975, Duluth, Minn. (April 1976).

Davies, P.H., et al.. "Acute and Chronic Toxicity of Lead to Bainbow Trout, Salmo gairdneri, in Hard and Soft Nater," Nater Resear ch, $10(3): 199-276 \cdot(1976)$.

De I.G. Solbe, J.F.. "The Toxicity of zinc sulphate to Rainbow Trout in Very Hard Vater," Water Research, $8(6): 389-391$ (1974).

De I.G. Solbe, J.F. and V.A. Cooper, "Studies on Toxicity of Copper Sulphate to stone Loach, Noemacheilus barbatuuuㅡㄴ (L.) in Hard Water," Nater Research, 10:523-527 (1976).

De I.G. Solbe, J.F. and V.A. Flook, "Studies on the Toxicity of zinc Sulphate and of Cadmium sulphate to stone Loach Noenacheilus bachatulus (L.) in Hard Hater," Journal of Fish Bioloqy. $7(4): 631-637(1975)$. 
Premling, C.R., "Acute Toxicity of the Lampricide 3-Trifluoromethyl-4-Nitrophenol (TFM) to Nymphs of Mayflies (Hexagenia sp.)." Investigations in Pish Control, U.S. Department of the Interior, Fish and Wildife Service, Washington, D.C. $(1975)$.

Inglis, A. and E.L. Davis, "Effects of Water Hardness on the Toxicity of Several organic and Inorganic Herbicides to Fish," U.S. Bureau of Sport Fisheries and 67. pp. 1-22 (1972).

Kawatski, J.A. and M.A. Bittner, "Dptake, Elimination and Biotransformation of the Iampicide 3-Trifluoromethyl-4-Nitrophenol (TFN) by larvae of the Aquatic

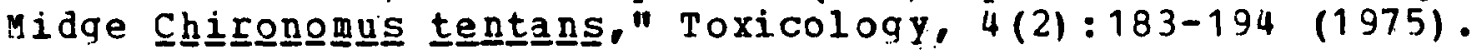

Kinkade, M.L. and H.E. Erdman, "The Influence of Hardness Components (Ca2t and Mg2t) in water on the optake and Concentration of Cadmium in a simulated Freshwater Bcosystem," Environmental Research, 10:308-313 (1975).

McCarty, L.S., J.A.C. Henry, and A.H. Houston, "Toxicity of

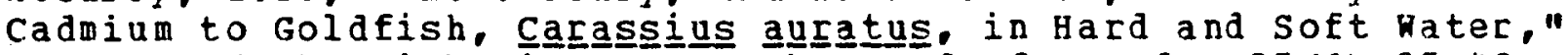
Journal of the Fisheries Research Board of Canada, 35(1):35-42 $(1978)$.

Maine Department of Environaental Protection, "Policy Regarding the Use of Copper Compounds as Aguatic Herbicides in Maine," Report by the Division of Iakes and Biological studies, Augusta (Feb. 1976).

Marking, L.L: and L.E. Olson, "Toxicity of the Lampricide 3-Trifluoromethyl-4-Nitrophenol. (TFM) to the Nontarget Fish.in static Tests," Investigations in Fish Control, U.S. Department of the Interior, Fish and Wild ife Service, Nashington, D.C. (1975).

Mitrovic, V.V., et al." "Some pathological Effects of Sub-acute and Acute poisoning of Rainbow Trout by Phenol in Hard Hater." vater Research, 2:249-254 (1968).

Mount, D.I.. "Effect of Total Hardness and pH on Acute Toxicity of Zinc to Fish," International Journal of Air and Water pollution, 10:49-56 (1966).

Neel. J.K., "Biotic Character as Related to stream Mineral Content," Transactions of the American Microscopical societ $92(3): 404-415$ (1973).

Pollard, C.B., "Physiological Effects of Mineral salts in Natural Waters," Journal of the American Water Works Association, 28:1038 $(1936)$. 
Salzinger, K.. et al.. "Behavior of the Goldfish as an Early Narning system for the presence of Pollutants in vater," Journal of Environmental systems, 3(1):27-40 (Spring 1973).

Sinley, J.R.. J.P. Goettl, Jr., and.P.H. Davies, "The Effects of Zinc on Rainbow Trout (Salng gairgdneri) in Hard and Soft Water." Bulletin of Environmental Contamination and Toxicology. $12(2): 193-201$ (1974).

Slonim, C.B. and A.R. Slonin, "Effect of Nater Hardness on the Tolerance of the Guppy to Beryllium Sulfate, "Bulletin of Fnviconmental Contamination and Toxicology, 10(5):295-301 (1973).

Sullivan, G. D. and A.L. Buikema, "The Effect of Hardness on the Toxicity of zinc sulfate to the Botifer Philodina sp.." ASB Bulletin 19:104 (abstract) (1972).

Tabata, K.. "Studies on the Toxicity of Heary yetals to aquatic inimals an the Factors to Decrease the Toxicity $I$. On the Formation and the Toxicity of Precipitates of Heary letals," Bulletin of Tokai Regional Fisheries Research Laboratory. $58: 203-214$ (1969).

Tabata, K.. "Studies on the Toxicity of Heary Metals to Aquatic Animals and the Factors to Decrease the roxicity II. Antaqonistic Action of Hardness Components in water on the Toxicity of Heavy Metal Ions," Bulletin of Tokil Regional Pisheries Research Laboratory, 58:2:15-232 (1969).

Tabata, K.. "Studies on the Toxicity of Heary Hetals to aquatic Animals and the Factors to Decrease the Toxicity. IV. on the Relation Between the Toxicity of Heary retals and the Quality of Environmental Nater," Bulletin of Tokai Regional Fisheries Research Laboratory, 58:243-253 (1969).

Trojnar, J.R.. "Egq and Larval Survival of Hhite Suckers (Castostomus commers Research Board of Canada, 34:262-266 (1977).

Troinar, J.R., "Egg Hatchability and Tolerance of Brook Trout (Salvelinus fontinalis) Fry at Low pH," Journal of the Fisheries Research Board of Canada, 34:574-579 (1977).

Wairood, K.G.. "Effects of Copper, Hardness and pH on suinming Performance and Growth of Rainbow Trout (Salego gaird므록)." Dissertations Abstracts, 38 (1977).

Younq, R.T., "Resistance of Fish to saits and alkalinity." American Journal of Physioloqy. $63: 373$ (1923). 
Zitko, v.. "Structure Activity Relations and the Toxicity of Trace Elements to Aquatic Biota," proceedings of the

International Joint Commission's workshop on Toxicity to Biota of Metal Forms in Natural Mater, R. H. Andrew, P.V. Hodson, and D.E. Konasewich, (eds.), Great Lakes Advisory Board, Findsor, pp.9-33 $(1976)$.

Zitko, V. and W.G. Carson, "A Mechanism of the Effects of Hater Hardness on the Lethality of Heavy Metals to Fish," Chemosphere, $5: 299-303$ (1976).

I RON

Ashley, L.M., "Action of Iron Salts in Solution on Goldfish," Progressive Fish-Culturist, 32:109 (April 1970).

Barica, J., M.P. Stainton, and A.L. Hamilton, "Mobilization of, Some Metals in vater and Animal Tissue by NTA, EDTA and TPP," water Research, 7:1791-1804 (1973).

Becker, A.J., Jr. and E.C. Keller, Jr., "Effects of Iron and Sulfate Compounds in the Growth of Chlorellag, " Proceedings of the West Virginia Academy of Science, 45:127 (1973).

Biesinger, R.E. and G.M. Christensen, "Effects of Various Metals on Survival, Growth, Reproduction, and Metabolism of Danghnia magna." Journal of the Fisheries Research Board of Canada. $29(12): 1691-1700$ (1972).

Boothe, P.N. and G.A. Knauer, "Possible Importance of Fecal Material in the Biological Amplification of Trace and Heavy Metals," Limnology and Oceanography. $17(2): 270-275$ (1972).

Bovee, B.C.. "Effects of Selected Chemicals on Movement, Growth, and Survival of Certain Aquatic Animal Life," National Technical In formation Service, Report No. PB-261388 (1976).

Brown, B. B.. "Effects of Mine Drainage on the River Hayle, Cornuall: A) Factors Affecting Concentrations of copper, zinc and Iron in ater. Sediments and Dominant Invertebrate Fauna," Hydrobiologia, $52(2 / 3): 221-233$ (1977); Biological Abstracts, 13612 (1977).

Cross, F.A. and J.H. Brooks, "Concentrations of Manganese, Iron, and 7inc in Juveniles of Five Fstuarine-Dependent Fishes," Radionuclides in Ecosystems, Vol. 2, D.J. Nelson, (ed.), Proceedings of the 3rd National Symposium on Radioecology, Oak Ridge, Tenn., po. 769-775 (tay 10-12, 1971). (Available from NTIS) 
Dah1. J.. "Transformation of Iron and Sulfur Compounds in soil, and Its Relation to Danish Inland Fisheries," Transactions of the merican Fisheries Society. 92:260-264 (1963).

Danie1s, R.R.. B.E. Struckmeyer, and I.A. Peterson, "Copper Toxicity in Rhaseolus vulgacis as Influenced by Iron Nutrition II. Elemental and Electron Microscope Analysis," Journal of the A werican Society for Horticultural Science, 98:31-34 (1973).

Decker, C.F. and P. Menendez, "Acute Toxicity of Iron and Aluminum to Brook Trout." Proceedings of the nest Virqinia academy of Science, 46:159 (1974).

Ebeling, G.. "Toxicity of Heavy Metals to Rainbow Trout," Journal of the American Water Norks Association, 23:1626 (1931).

Elder, J.F. and A.J. Horne, "Biostimulatory Capacity of Dissolved Iron for Cvanophycean Blooms in a Nitrogen-Rich Beservoir," Chemosphere, 9:525 (1977).

Establier, R. and E. Pascual, "Studies on Copper. Iron.

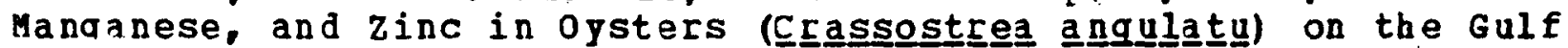
of Cadiz," Investiqacion Pesquera, 38(2):371-384 (April 1974).

Frahm, J.P., Noxicity Tolerance studies ntilizing Periphyton (Toxitoleranzversuche an Nassermoosen)." Gewasser und abwasser. 57/58:59-66 (1975).

Frazier, J.H.. "The Dpnamics of Metals in the American oyster,

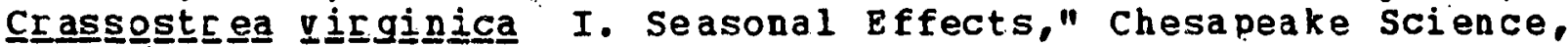
$16(3): 162-171(1975)$.

Frazier, J.M., "The Dyramics of Metals in the American Oyster.

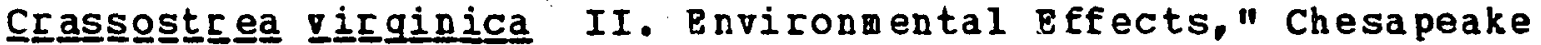
Science, $17(3): 188-197$ (1976).

Greenfield, J.P. and M.P. Ireland, "A Survey of the Macrofauna of a Coal-Waste Polluted Lancashire Fluvial System," Environmental Pollution, 16:105 (1978).

Helz, G.R., R.J. Buggett, and J.M. Hill, "Beravior of Mn, Pe, Cu, $\mathrm{Zn}$, $\mathrm{Cd}$, and $\mathrm{Pb}$ Discharqed from a Wastewater Treatment plant into an Estuarine Environment," Water Research, 9:631-636 (1975).

Hem, J.D. "Chemical Factors that Influence the Availability of Iron and Manganese in aqueous systems," Geological society of America Bulletin, 83:443-450 (1972).

Huckabee, J.W., C.P. Goodyear, and R.D. Jones, "ACid Rock in the Great Smokies: Unanticipated Impact on Aquatic Biota of Road construction in Regions of sulfide Mineralization," Transactions of the American Fisheries Society. 4:677-684 (1975). 
Jenne, E. A., "Controls on Mn. Fe, Co, Ni, Cu, and $\mathrm{Zn}$ Concentrations in Soils and Water: The significant Role of Hydrous Mn and Fe Oxides," Advanced Chemistry, 73:337-387 (1968).

Koelling, J.J., "Relationship of Trace Elements to Alqae Growth," $\mathrm{Ph}$.D. thesis, Washington State University, Pullman (1971).

Kuenzler, E.J.. "Flimination of Iodine, cobalt, Iron and zinc by Marine Zooplankton," Symposium on Radioecology, D.J. Nelson and F.C. Evans, (eds.), Oak Ridge, U.S. Atomic Energy Commission Technical Information Division, pp. 462-473 (1969).

LaRoze, A., "A Contribution to the study of the Toxic Action of Iron on Pish," Biological Abstracts, 31:1379 (1957).

Levis, W.M." "Suitability of Well-Hater with a High Iron Content for Narm-Mater Fish Culture," Progressive Fish-Culturist, 22:79 (1960).

Minkina, A.L.. "On the Action of Iron and Aluminum on Fish," water Pollution Abstracts, Vol. 23 (1950); rrudy Moskorskogo zooparka (in Russian); 3:23-26 (1946).

Morgan, R.P., II.. et al.," "Sublethal Effects of Baltimore Harbor Water on the white perch, arone angericana, and the Hogchoker,

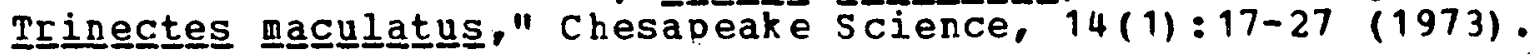

Murphy, T.P., et al.. "Blue-Green Algae: Their Excretion of Iron-Selective Chelators Enables them to Dominate Other Algae," Science, 192:900 (1976).

Nielson, S.S.. "Toxicity to Pish of Waste Waters Containing Iron and Copper." Water Pollution Abstracts, Vol. 12 (1939).

Patrick, F.M. and M.W. Loutit, "Passage of Metals in Effluents, Through Bacteria to Higher Organisms," Water Research, 10:333-335 $(1976)$.

Pentreath, R.J., "The Accumulation from Nater of $65 \mathrm{za}, 54 \mathrm{n}$, $58 \mathrm{Co}, 59 \mathrm{Fe}$ by the Mussel Mytilus edulis," Journal of the Marine Biological Association of the United Kingdom, 53:127-143 (1973).

Porter, K.R. and D.E. Hakanson, "Toxicity of Mine-Drainage to Embryonic and Larval Boreal Toads (Bufonidae: Bufo booreass)." Copeia, 2:327-331 (1976).

Saliba, L.J. and R.M. Krzyz, "Effect of Heary Metals on Hatching of Brine Shrimp Eggs," Marine Pollution Bulletin, 7(10):181-182 $(1976)$.

Scheier, A. and P. Kiry, "A Discussion of the Effects of Certain Potential Toxicants on Fish and Shellfish in the opper Delaware Estuary," Academy of Natural Sciences of Philadelphia, Penn. (Dec. 1973). (NTIS PB-231 423) 
Smith, E.J., "Effects of Line Neutralized Iron Hydroxide Suspensions on Selected Species of North American Fish;" Ph.D. thesis, Dniversity of Pittshurgh, Graduate school of public Health (1973).

Smith, E.J. and J.L. Sykora, "Early Developmental Effects of Lime-Neutralized Iron Hydroxide Suspensions on Brook Trout and Coho Salmon," Transactions of the merican Fisheries society. 105: $308(1976)$.

Sodergren, S., "Ecological Effects of Heavy Metal Discharge in a Salmon River," Drottningholm, Sweden. Institute of Freshwater Research, Report 55:91 (1976).

Starkey, R.I.., "Transformations of Iron by Bacteria in 420 ," Journal of the American Rater Horks Association, 37:963 (1945).

Sykora, J.I., E.J. Smith, and M.A. Shapiro, "Chronic Effect of Ferric Hydroxide on Certain species of Aquatic Animals," Proceedings of the 4 th symposium on Coal line Drainage Research, Mellon Institute, Pittsburgh, p. 347 (April 26-27, 1972).

Sykora, J.I., E.J. Smith, and M. Synak, "Effect of Lime Neutralized Iron Hydroxide Suspensions on Juvenile Brook Trout

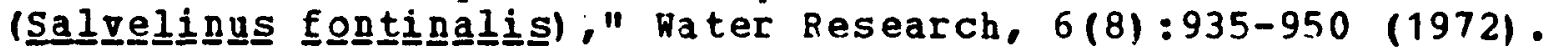

Sykora, J.L., et al.. "Soue Observations on spawning of Brook Trout (Salveiinus fontinalis, Mitchill) in Lime Neutralized Iron Hydroxide Suspensions," Water Research, 9 (4):451-458 (1975).

Trollope, D.R. and B. Evans, "Concentrations of Copper, Iron, Lead, Nickel and zinc in Freshwater Algal Blooms," Environmental Pollution, 11:109-116 (1976).

Warnick, S.L. and H.L. Bell, "Acute Toxicity of Some Heary Metals to Different Species of Aquatic Insects," Journal of the Water pollution Control Pederation, $41(2): 280-284$ (1969).

Holfe, D.A., et al.. "The Flux of Mn. Fe, and $\mathrm{Zn}$ in an Estuarine Ecosysten." proceedings of the Symposium on Radioactive Contamination of the Marine Fnvironment, International Atomic Energy Aqency, Seattle, Washington, 159 pp. (1973).

Wolfe, R.S.. "Microbial Concentration of Iron and Manganese in water with Low Concentrations of These Elements," Journal of the American Vaterworks Association, 52:1335 (1960).

Young. M.L., "Transfer of $65 \mathrm{zn}$ and $59 \mathrm{Fe}$ Along Two Marine Food Chains," Ph.D. thesis, University of East Anqlia, Norwich, Finaland (1974). 
L RAD

Adams, E.S., "Effects of Lead and Hydrocarbons from snowmobile Exhaust on Brook Trout (Salvelinus fontinzlisis)," Transactions of the American Fisheries Society. 104(2):363-373 (1975).

Alekseenko, V.A.. et al.. "Migration of Lead and zinc in surface Waters During the sharp Enrichment of the Naters with sulfides of the Metals," Izvestiya Akademii Nauk Kazakhskoi SSR, Seriya Geoloqich eskaya (OSSR) , $30(2): 76$ (1973); Chemical Abstracts, $79: 209$ (1973).

Anderson, R. V., "Cadmiun, Copper, Lead, and zinc: Tracemetal Dollutants in an Aquatic Ecosystem," NSF-SOS Grant GY-10814 Final Report, National science Foundation, Washington, D.C., 275 pp. (1973).

Anderson, R.V., "The Occurrence of Cadmium, Copper, Lead, and Zinc in Macroinvertebrates of the Fox River, Ilinois,"

nnpublished M.S. thesis, Department of Biological science, Northern Illinols University, DeKalb, 134 pp. (1975).

Anderson, R.V., "Concentration of Cadmium, Copper, Lead, and zinc in Thirty-Five Genera of Freshwater Macroinvertebrates From the Fox River, Illinois and Nisconsin," Bulletin of Environmental contamination and Toxicology, 18(3):345-349 (1977).

Anderson, R.V.. "Concentration of Cadmium, Copper, Lead and zinc in Six Species of Freshwater Clams," Bulletin of Environmental contamination and Toxicology, 18(4):492 (1977).

Anderson, R.V., H.S. Vinikour, and J.E. Brower, "The Distribution of $C d, C u, P b$ and $\mathrm{Zn}$ in the Biota of Two Freshwater sites with Different Trace Metal Inputs," Holarctic Ecology, 1:377-384 (1978).

Aronson, A.L.." "Bioloqical Effects of Lead in Fish," Journal of the Washington Academy of Science, $61(2): 124-128$ (1971).

Aubert, M., et al.. "Utilization of a Trophodynamic Chain of a Pelaqic Type for the study of Transfer of Metallic Pollution," Revue Internationale d'Oceanographie Medicale, 28:27-52 (1972).

Aubert, M.. et al.. "Use of a Neritic Trophodynamic Chain of Molluscs for the study. of the Transfer of Metallic Pollutants," 6 th Symosium of the Internationale doceanographie Medicale, Portoroz, Yuqoslavia (Sept. 26-30, 1973): Revue Internationale d'oceanographie Medicale. 33:7-30 (1973). (NTIS CONF-7309103-1)

Barica, J., M.P. Stainton, and A.L. Hamilton, "Mobilization of Some Metals in Water and Animal rissue by NTA, EDTA and TRP," Hater Res earch, 7:1791-1804 (1973). 
Barsdate, R.J.. "Pathways of Trace Elements in Arctic Lake Ecosystems," Dnjuersity of Alaska, Fairbanks; Institute of Marine science, (1972). (NTIS RLO-2229-T2-1)

Benifts-claus, C. and F. Benijts, "Effect of Low lead and zinc Concentrations on the Larval Development of the Hudcrab

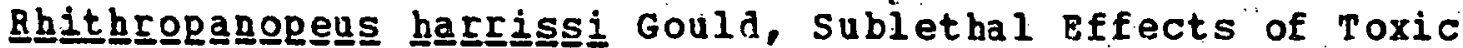
Chemicals on Aquatic animals." proceedings of the Swedish-Netheriands Symposium, Nageningen, Neth.. 43 (1975).

Birge, H.J. and J.J. Just, "sensitivity of Vertebrate Embryos To Heary Metals as a Criterion of Water Quality," Kentuck Mater Resources Institute, Lexington (1973): (NTIS PB-226-850)

Birge, W.J.. et al.. "Sensitivity of Vertebrate Embryos to Heary Metals as a criterion of Water Quality. Phase I," Rentuck Water Resources Institute, Lexington (1974). (NTIS PB-226-850/LI)

Boothe, P.N. and G.A. Knauer, "Possible Importance of Fecal Material in the Biological ampification of Trace and Heavy Metals," Limnology and Oceanography, 17(2):270-275 (1972).

Brown. B.E.. "observations on the Tolerance of the Isopod Aselly

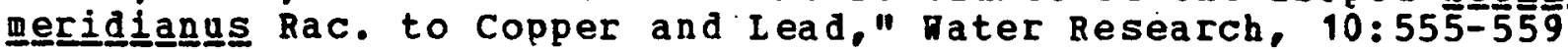
$(1976)$.

Brown. B. E.. "Optake of Copper and Lead by a Metal-Tolerant Isopod Aselius mexidiannus Rac.," Freshwater Biology. 7 (3):235-244 (1977).

Brown. V.H.. "The Calculation of the Acute Toxicity of uixtures of Poison to Rainbow Trout," Water Research, $2(10): 723-733$ $(1968)$.

Bryan, G.H.. "Some Aspects of Heavy Metal Tolerance in Aquatic organisms," A.P.M. Lockrood, (ed.). Cambridge Oniversity press, N.Y.. 35 pp. (1977).

Bucke, D.. "Neoplasia in Roach (Rutilus rutuilus L.) from a polluted Environment," Progress in Experimental Tumor Research, $20: 205(1976)$.

Buikema, A.L.. Jr.. J. Cairns, Jr., and G. M. Sullivan, "Evaluation of philodina acuticornis (Rotifera) as a Bioassay Orqanism for Heavy Metals," Water Resources Bulletin, $10(4): 648-661(1974)$.

Carpenter, K.E. "On the Biological Factors Involved in the Destructicn of River-Pisheries by pollution Due to. Lead Mining," Annals of Applied Biology. 12:1-13 (1925).

Carter, J.W. and I.I. Cameron, "Toxicity Bioassay of Heary Metals

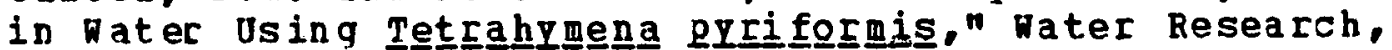
$7(7): 951-961$ (1973). 
Chapman, G., "Effect of Heary Metals on Fish," Oregon State University Water Resources Research Peport No. SEMN-WR-D16.73, pp. 141-162 (Jan. 1973).

Cheremisinoff, P. and Y. Habib, "Cadmium, Chromium, Lead, and Mercury - Plenary Account for water Pollution I. Occurrence. Toxicity, and Detection," Water and Sewage Works, 119:73 (1972).

Chow, T.J., H.G. Snyder, and.C.B. Snyder, "Mussels (Mytilus sp.) as an Indicator of Lead Pollution," The Science of the Total Environment, $6: 55-63(1976)$.

Christensen, G.M., "Biochemical Effects of Methylmercuric Chloride, Cadmium Chloride and Lead Nitrate on Embryos and

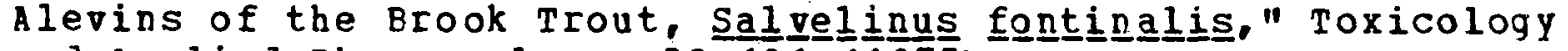
and Afplied Pharmacology, 32:191 (1975).

Cole. A.E.. "Effects of Pollutional Wastes on Fish Life," Symposium on Hydrobiology, Oniversity of Wisconsin, Madison, $p$. $241(1941)$.

Coughtrey, P.J. and M.H. Martin. "The Uptake of Lead, Zinc, Cadmium, and Copper by the Pulmonate Mollusc, Helíx a Muller, and Its Relevance to the Monitoring of Heavy. Metal Contamination of the Environment," Decolodia, 27:65-74 (1977).

Crandall, C.A. and C.J. Goolnight, "The Effects of Sublethal Concentrations of Several Toxicants to the common Guppy. Lebistes reticula $82: 59-73-(1963)$.

Davies, P.H., "Chronic Toxicity of Lead to Rainbow Trout," M.S. thesis, Colorado state oniversity. Fort Collins (1972).

Davies, P.H.. "Need to Establish Heavy Metal Standards on the Basis of Dissolved Metals," Proceedings of the International Joint Commission's vorkshop on Toxicity to Biota of Metal Forms in Natural water, October 7-8, 1975, Duluth, Minn. (April 1976).

Davies, P.H. and H.H. Everhart, "Fffects of Chemical Variations in Aquatic Environments III. Lead Toxicity to Rainbow Trout and Testing Application Pactor Concept," 0.5 . Environmental Protection Agency. Ecological Research Series Report EPA-R 3-73-011C (1973).

Davies, P.H., et al., "Acute and chronic Toxicity of lead to

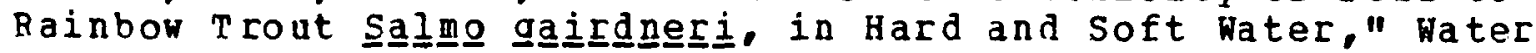
Research, $10(3): 199-206(1976)$.

Dawson, A.B., "Hemopoietic Response in the Catfish, Aquei $\underline{\underline{u}} \underline{\underline{u}} \underline{\underline{S}}$ neh hul los Hole, Mass.), 68:335-346 (1935). 
Dayton, L. and R.A. Lewin. "Effect of Lead on Algae III. Effects of Lead on Population Growth Curves in Tro-Membered Cultures of Phytoplankton," Archiv fuer Hydrobiologie, supplementband, 49:25 (1975).

Dilling, H.J. and C.H. Healey. "Influence of Lead and the Metallic Ions of Copper, Zinc, Thorium, Beryllium, and Thallium on the Germination of Frogs' Spawn and on the Growth of Tadpoles," Annals of Applied Biology. 13(2):177-188 (1926): Biological Abstracts, 2:3485 (1928).

Dorfman, D. and W.R. Whitworth, "Effects of Fluctuations of Lead, Temperature, and Dissolved oxygen on the Growth of Brook Trout," Journal of the Fisheries Research Board of Canada, 26:2493-2501 (1.969).

Eisler, R." "Acute Toxicities of Selected Heavy Metals to the Softshell clam. ㅂya a Contamination and Toxicology, 17:137 (1977).

Enk. M.D. and B.J. Mathis, "Distribution of Cadmiun and Lead in a Stream Ecosystem," Hydrobiologia, 52:153 (1977).

Fedkenheuer, P.J., (ed.). "Impact of lead Mine and Mill Effluent on Aquatic Life," $47 \mathrm{th}$ Annul Meeting and $35 \mathrm{th}$ Annual Mining symposium, American Institute of Mining, Metallurgical, and petroleun Enqineers, Mineral Resources Research Center. Minneapolis, 150 pp. (1974).

Fiussello, N., "Lead Pollution Effects on Chlorophyll," Informatore Botanico Italiano, 5:107-108 (1973).

Gaechter, R., "Heavy Metal Toxicity and synergism to Natural Phytoplankton in the Eutrophic lake Alpnach and the llesotrophic Horv Bay," Schweizerische Zeitschrift fur Hydrologie, 38(2):97 $(1976)$.

Gale, N.L., P. Marcellus, and G. Onderwood, "Life, Liberty and the Pursuit of I.ead: The Impact of Lead Mining and rilling. Activities on aquatic organisms," Trace contaminants in the Environment, Proceedings of the 2 nd Annual NSF-FANN Trace Contaminants Conference, Asilomar, Pacific Grove, Calif. (Aug. 29-31, 1974).

Gale, N.L.., et al.. "Aquatic Organisms and Heavy Hetals in Missouri's New Lead Belt," Bulletin of American nater Resources Association, 9:673-688 (1973).

Gale, N.L.., et al.. "Transport of Trace Pollutants in Lead Mining Waste Waters," Trace substances in Environmental Health IV, p. 95 (1973). 
Gale, N.L... et al.. "The Impact of Lead Mine and Mill Effluents on Aguatic Life," Presented at the Environmental session of the Mining Symosium, University of Minnesota, Minneapolis (Jan. 1974).

Gale, N.L., et al.. "Impact of Lead Mine Effluents on Aquatic I.ife," Proceedings of the $35 t h$ Annual Mining Symposium, P.J. Fedkenheuer, (ed.), American Institute of Mining, Metallurgical, and Petroleum Engineers, Duluth, Minn. (1974).

Gray. J.S.. "Synergistic Effects of Three Heavy Metals on Growth Rates of a Marine Ciliate Protozoan," In: Pollution and Physiology of Marine Organisms, F.J. Vernberg and H.B. Vernberg, (eds.). Academic Press, New York, pp. 465-485 (1974).

Gray, J.S. and R.J. Ventilla, "Growth Rates of sediment-living Marine Protozoan as a Toxicity Indicator for Heavy Metals," Ambio, $11(4): 118-121$ (1973).

Hahne, H.C. and H. Kroontje, "Significance of pH and Chloride Concentration on Behavior of Heavy Metal Pollutants: Mercury (II), Cadmium (II), Zinc (II), and Lead (II), "Journal of Environmental Quality, 2:444-451 (1973).

Haider, G.. "Studies on the Heavy Metal Poisoning of Fishes I.

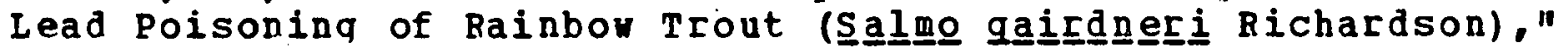
zeitschrift fuer Angewandte zoologie, 51:347-366 (1964).

Hannan, P.J. and C. Patouillet, "Effect of Mercury on Algal Growth Rates," Biotechnology and Bioengineering, 14:93-101 (1972).

Helz, G.R., R.J. Huggett, and J.M. Hill, "Behavior of Mn, Fe, Cu, $\mathrm{Zn}$. $\mathrm{Cd}$, and $\mathrm{Pb}$ Discharged from a Wastewater Treatment Plant into an.Fstuarine Environment," Water Research, 9:631-636 (1975).

Hessler, A.. "Effects of Lead on Algae II. Mutagenesis Experiments on platymonas sub volvocales)." Mutation Research, 31:43-47 (1975).

Holcombe, G.W., et al.. "Long-Term Effects of Lead Exposure on Three Generations of Brook Trout (Salvelinus fontingali Journal of the Fisberies Research Board of Canada, $33: 1731-1741$ (1976).

Hutchinson, T.C., "Comparative studies of the Toxicity of Heary Metals to phytoplankton and Their synergistic Interactions," Rater Pollution Research in Canada, 8:68-90 (1973).

Jackim, E.." "Influence of Lead and other Metals on Fish Delta-Aminolevulinate Dehydrase Activity," Journal of the Fisheries Research Board of Canada, 30 (4):560-562 (1973). 
Jackim, E., J.M. Hamlin, and S. Sonis, "Effects of Hetal Poisoning for Five'Liver Enzymes in the Rillifish (Funduulus heteroclitusl." Journal of the Fisheries Research Board of Canada, 27:383-390 (1970).

Jenkins, D.W., "Flow of Toxic Metals in the Environment," International Conference on Environmental Sensing and Assessment, Vol. I, Las Vegas, Nev. (Sept. 14-19, 1975).

Jones, J.R.E.. "Relative sensitivity of Aquatic species to Lead in Solution," Appendix of Animal Ecology. 7:287-289 (1928).

Jones, J.R.E.. "The Relative Toxicity of Salts of Lead, zinc and Copper to the stickleback (Gasterosteus aculeatus $L$.$) and the$ Effect of Calcium on the Toxicity of Lead and zinc salts," Journal of Experimental Biology, 15:394-407 (1938).

Jones, J.R.E., "Fanna of the River Melindur, a Lead Polluted Trlbutary of the River Rheidol in North Cardiganshire, Nales," Journal of Animal Ecology, 9:188-201 (1940).

Ralabina, N.M.. et al.. "Effects of the Toxic Substances in Effluents from Non-Fercous letal Industries on the Microorganisms and Biochemical processes Associated with the self-purification of Water in Storage Basins," Gigiena (USSR), 9(10): 1 (1944).

Kerfoot, T.B. and G.A. Redmann, "Permissible Levels of Heavy Metals in Secondary Effluent for ose in a Combined Sewage Treatment-Marine Agriculture system II. Develooment of Guidelines by Method of Additions," proceedings of the conference on Nastewater Use in the Production of Food and Fiber. Oklahoma city, Okla.. pp. 79-101 (March 5-7, 1974).

Kinnison, R.R.. "Pb:," Environmental Science and Technology. $10: 644-649(1976)$.

Knauer, G.A. and J.H. Martin, "Sea sonal Variations of Cadnium, Copper, Manganese. Lead, and zinc in pater and Phytoplankton in Monterey Bay, California," Iimnology and Oceanography, 18(4) 597-604 (1973).

Leland; H.V. and J.M. McNurney, "Lead Transport in a River Ecosystem, " Presented at the International conference on Transport of Persistent Chemicals in Aquatic Ecosystems. The National Research Council of Canada, 25 pp. (1974).

Lu. P., et al.. "Hodel Ecosysten Studies of Lead and Cadmium and of Urban Sewage sludge Containing These Elements," Journal of Environuental Quality. 4:505 (1975).

McIntosh, A. and W. Bishop. "Distribution and Effects of Heary Metals in a Contaminated Lake," Technical Report No. 85. OWRT/A-036-IND (1), U.S. Department of Commerce, NTIS, Sprinqfield, Va. (1976). 
Mafori, L and F. Petronio, Marine Pollution by Metals and Their Accumulation by Biological Indicators (Accumulation Factor)," Revue Internationale d'oceanographie Medicale, 31/32:55-90 (1973).

Malanchuk, J,L. and G.K. Gruendling, "Toxicity of Lead Nitrate to Algae," water, Air, and Soil Pollution, 2 (2):181-190 (1973).

Matbis, B.J. and N.R. Kevern; "Distribution of Mercury, Cadmium, Lead and Thallium in a Eutrophic Lake," Hydrobiologia, $46(2-3): 207-222$ (1975).

Merlini, M. and G. Pozzi, "Lead and Freshwater Fishes: Part 1 Lead ccumulation and Nater pH," Environmental Pollution, $12: 167-172$ (1977).

Merlini, M. and G. Pozzi, "Lead and Freshwater Fishes: Part 2 Ionic Lead Accumulation," Environmental Pollution, 13:119-126 $(1977)$.

Namminqa, H.E., J.E. Scott, and S.L. Burks, "Distribution of copper, Lead, and zinc in selected components of a pond Ecosystem," Proceedings of the oklahoma Academy of science, $54: 62-64(1974)$.

Patrick, F.M. and M.H. Loutit, "passage of vetals in Effluents, Through Bacteria to Higher Organisms," Water Research, 10:333-335 $(1976)$.

Phillips, D.J.H., "Common Musel Mytilius eduiㅗ을 as an Indicator of Pollution by zinc, cadmium, Lead, and copper I. Effects of Environmental Variables on Uptake of Metals," Marine Biology. $38: 59-69(1976)$.

Ray, S. and H. Wite, "Selected Aquatic Plants as Indicator Species for Heary letal Pollution," Journal of Environmental Science and Health, A-11(12):717-725 (1976).

Reish, D.J., et al., "The Effect of Heary Metals on Laboratory Populations of Tro polychaetes with comparisons to the Hater ouality conditions and standards in Southern California darine Waters," Water Research, 10:290-302 (1976).

Ridler, ..P., et al.. "Biomethylation of Toxic Elements in the Environment," Science, 197:329 (1977).

Ruthven, J.A. and J. Cairns, Jr.. "Response of Fresh-Hater Protozoan Artificial Com unities to Metals," Journal of Protozoology, 20(1):127-135 (1973).

Saliba, L.J. and R.H. Rrzyz, "Effect of Heary Metals on Hatching of Brine Shrimp Eqgs," Marine Pollution Bulletin, $7(10): 181-182$ $(1976)$. 
Salzinger, R.. et al.. "Behavior of the Goldfish as an Early Warnina system for the Presence of Pollutants in Water," Journal of Enviconmental systems. 3(1):27-40 (Spring 1973).

Sartory, D.P. and B.J. Lloy,. "The Toxic Effects of selected

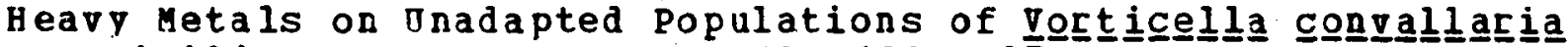
Var Similis." Water Research, 10:1123 (1976).

Sauter, S., et al.." "Effects of Exposure to Heavy Metals on Selected Freshwater Fish, Toxicity of Copper, Cadmium, Chromium and Lead to Eggs and Fry of Seven Fish Species," U.S. Environmental Protection Agency Report EPA-600/3-76-105, Duluth。 Minn., 75 pp. (1976).

Scheier, A. and P. Kiry, "A Discussion of the Effects of Certain Potential Toxicants on Fish and Shellfish in the Upper Delaware Estuary." Academy of Natural Sciences of Philadelphia. Penn. (Dec. 1973). (NTIS PB-231423)

Schulz-Baldes. M.. "Lead Optake from Seawater and Food, and Lead Loss in the Common Mussel, Mytilius eduliss," Marine Biology. 25:177-193 (1974).

Schulz-Baldes, M. and R.A. Lewin, "Lead Optake in Two Marine Phytoplankton Organisms," Biological Bulletin, 150:118 (1976).

Shukla, S.S. and H.V. Leland, "Heavy Metals: A Review of Lead," Journal of the water pollution Control Federation, $45(6): 1319-1331$ (1973).

Stein, J.N. and M.D. Miller, "An Investigation into the Effects of a zinc-lead Mine in the quatic Environment on Great slave Lake," Technical Report, Resource Management Branch, Department of the Environment Fisheries and Marine Service, Winnipeg, Manitoba. $56 \mathrm{pp}$. (1972).

Sterart, J.G.. "Effects of lead on the Growth of Four species of Red Algae," Phycologia, 16: 31 (1977).

Stupka, R.C., "An Analysis of the Behavior and Effects of Lead Pollution on a Terrestrial and Aquatic Ecosystem in the opper Great Lakes Region," Final Project Report, National science Foundation Grant No. GY-9135, 176 pp. (1971).

Tarzwell, C.M. and C. Henderson, "Toxicity of Some of the Less Common Metals to Fishes," Transactions of the seminar on Sanitary Engineering Aspects of the stomic Energy Industry, Robert A. Taft Engineering Center Report TID-7517 (1956).

Tarzwell, C.M. and C. Henderson, "Toxicity of Less Common Metals to Fishes," Industrial hastes, 5:12 (1960). 
Thormann, D., "Fffects of Cadmium and Lead opon the Indigenous Heterotrophic Microflora in the Aqueous Environment of the Brackish Bstuary water of the River Neser," Veroeffentlichungen des Instituts fuer Meeresforschung in Bremerhaven, 15:237 (1975).

Trollope, D.R. and B. Evans, "Concentrations of Copper, Iron, Lead. Nickel and Zinc in Freshwater Algal Blooms," Environmental pollution, 11:109-116 (1976).

Turnbull, H., J.G. DeMann, and R.F. Neston, "Toxicity of Various Refinery Metals to Freshwater Fish," symposium on haste Disposal in the petroleun Industry. Industrial Enqineering and Chemistry, $46: 324(1954)$.

U.S. Department of the Interior. "Trace Elements in water - A Bibliography," office of Nater Resources Research Report WRSIC 71-202, 286 pp. (June 1971). (NTIS PB 201 266)

U.S. Environmental Protection Agency, "Biological Aspects of Lead: An Annotated Bibliography," superintendent of Documents. U.S. Government Printing office, Washington, D.C., 20402 (1972). $(\mathrm{AP}-104)$

Varanasi, D., P.A. Robisch, and.D.C. Malins, "Structural Alterations in Fish Epidermal Mucus Produced by Waterborne Lead and Mercury," Nature, 258 (5534):431-432 (1975).

Vinikour. W.S." "Concentrations of Zinc, Copper, Cadmium, and Lead in selected Fish species of the Fox River from Locations with Varying Potential Metal Inputs;" M.S. thesis, Northern Illinois University, Dekalb, 103 pp. (Dec. 1977).

Warnick, S.L. and H.L. Bell, "Acute Toxicity of Some Heary Metals to Different Species of Aquatic Insects," Journal of the Water Pollution Control Federation, 41(2):280-284 (1969).

Whitley, L.S. and R.A. Sikora, "Effect of Three common Rollutants on the Respiration Rate of Tubificid Norms," Journal of the Hater Pollution Control Federation, Part 2, pp. R57-R66 (1970).

Whitton, B.A., "Toxicity of Heavy Metals to Freshwater Algae: A Review," Phykos, 9 (2):116-125 (1970).

Whitton, B.A., "Toxicity of zinc, Copper, and Lead to Chlorophyta from Flowing. Waters," Archiv fuer Mikrobiologie, 72:353-360 $(1970)$.

Wier, P.A. and C.H. Hine, "Effects of Various Metals on Behavior of Conditioned Goldfish," Acchives of Envicormental Health, $20(1): 45-51(1970)$. 
Wixson, B.G., et al., "An Interdisciplinary Investigation of Environmental pollution by Lead and other Heavy Metals from Industrial Development in the New Lead Belt of Southeastern Missouri," Interim Progress Report for the Period of June, 1971 to May. 1972. Submitted to the National science Poundation, BaNN (Research Applied to National Needs) Lead Study Prograt, Vols. I and II (1972).

MoolerY, M.L. and R.A. Lewin, "The Effects of Lead on Algae IV. Effects of Lead on Respiration and Photosynthesis of.

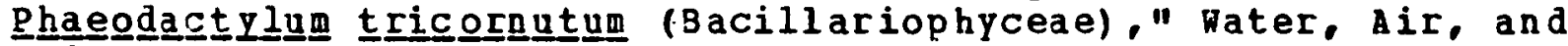
Soil poliution, 6(1):25-31 (1976).

Zavodnik, N.. "Note on the Effects of Lead on Oxygen Production of Several Littoral Seaweeds of the Adriatic sea," Botanica.

Marina, 20:167 (1977).

MAGNES IOH

Braek, G.S.G., A. Jensen, and A. Mohus, "Heavy Metal Tolerance of Marine Phytoplankton III. Combined Effects of Copper and zinc Ions on cultures of Four Common species," Journal of Experimental Marine Biology and Ecology, 25(1):37-50 (1976).

Hutchinson, G.F.. "Experimental studies in Ecology I. The Magnesium Tolerance of Daphniidae and its Ecological Significance," International Review of Hydrobioloqy, 28:90-108 (1933).

Kinkade, M.I. and H.E. Erdman, "The Influence of Hardness Components ( $\mathrm{Ca} 2+$ and $\mathrm{Mg} 2+$ ) in water on the Optake and Concentration of Cadmium in a Simulated Freshwater Ecosysten," Environmental Research, 10:308-313 (1975).

Neel. J.K.. "Biotic Character as Related to stream Mineral Content," Transactions of the American Microscopical Society. $92(3): 404-415$ (1973).

Pfeifer, E., "Maqnesium Necrosis in Carp," Archives of Fxperimental Pathology and Pharmacology, 216:375-380 (1952).

Salzinger, R., et al., "Behzvior of the Goldfish as an Early Warning system for the presence of Pollutants in Mater," Journal of Enviconmental Systems, 3(1):27-40 (Spring 1973).

Scheier, A. and P. Kiry; "A Discussion of the pffects of Certain potential Toxicants on Fish and Shellfish in the opper Delaware Estuary." Academy of Natural sciences of Philadelphia. Penn. (Dec. 1973): (NTIS PB-231423) 
U.S. Department of the Interior, "Magnesium in Water - A Bibliography," office of water Resources Besearch Report, WRSIC 71-206, 152 Pp. (July 1971). (NTIS No. PB 201271 )

\section{MANGANESE}

Barica, J., M.P. Stainton, and A.I. Hamilton, "Mobilization of Some Metals in Water and Animal Tissue by NTA, EDTA and TPP," Water Research, 7:1791-1804.(1973).

Boothe, P.N. and G.A. Knauer, "Possible Importance of Pecal Material in the Biological mplification of Trace and Heary Metals," Limnoloqy and Oceanography, 17(2):270-275 (1972).

Bryan, G.W. and L.G. Hummerstone, "Adaptation of the polychate

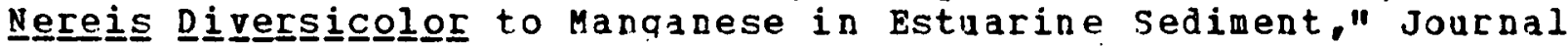
of the Marine Biological Association of the United Ringdom, $53: 85$ ? $-872(1973)$.

Calabrese, A., et al., "Toxicity of Heavy Metals to Embryos of the American oyster crasssostrea virgqinica," Marine Biology. $18: 162-166(1973)$.

Cross, F.A. and J.H. Brooks, "Concentrations of Manganese, Iron, and Zinc in Juveriles of Five Estuarine-Dependent Fishes," Radionuclides in Ecosystems, Vol, 2, D.J. Nelson, (ed.), Proceedings of the 3rd National Symposium on Radioecology, Oak Ridqe, Tenn., pp. 769-775 (May 10-12, 1971). (Available from NTIS)

Cumming, K.B. and D.M. Hill, "Stream Faunal Recovery after Manganese Strip Mining Reclamation," U.S. Environmental Protection Agency. Water Pollution Control Research Series No. 18050-D014 (June 1971).

Eisler, R.. "Acute Toxicities of Selected Heavy Metals to the Softshell clam, Mya arenarizi," Bulletin of Environmental contamination and Toxicology, 17:137 (1977).

Establier, F. and E. Pascual, "Studies on Copper, Iron,

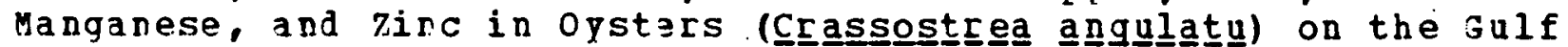
of Cadiz," Investigacion Pesquera, 38 (2):371-384 (Âpril 1974 ).

Frazier, J.M.. "The Dynamics of Metals in the american Oyster,

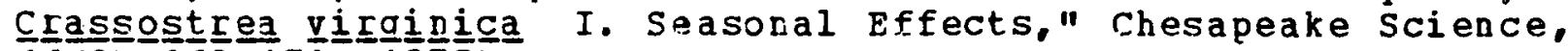
$16(3): 1 \frac{1}{6}-17 \frac{1}{1}\left(19 \frac{1}{7} 5\right)$.

Frazier, J.M., "The Dynamics of Metals in the American Oyster,

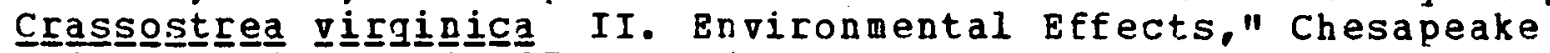
Science, $17(3): 188-197$ (1976). 
Gusseva, K.A., "Effect of Manganese on the Development of Algae," Water Pollution Abstracts, Vol. 20 (Feb. 1947).

Harvey, H.W." "Manganese and the Growth of Phytoplankton," Journal of the Marine Biological Association of the United Kingdom, $26: 562(1947)$.

Helz, G.R., B.J. Huggett, and J.M. Hill, "Behavior of Mn, Fe, Cu, $\mathrm{Zn}, \mathrm{Cd}$, and $\mathrm{Pb}$ Discharged from a Wastewater Treatment Plant into an Estuar ine Environment," Nater Research, 9:631-636 (1975).

Hem. J.D. "Chemical Pactors that Influence the Availability of Iron and Mananese in Aqueous systems," Geological Societ Anerica Bulletin, 83:443-450 (1972).

H111, D.M.." "Stream Faunal Recovery After Manqanese strip dine Reclamation," Ph.D. thesis, Oniversity of Michigan, Ann arbor (1972).

Hiltibran, R.C., "Effects of Cadmium, Zinc, Manganese, and Calcium on Oxygen and Phosphate Metabolism of Bluegili Liver Mitochondria," Journal of the vater Pollution Control Federation. $43(5): 818-823$ (1971).

Iwao, T.. "Comparative Investigations of the Toxicity of Various Metals," Journal of the Hater Pollution Control Federation, 32:67 $(1960)$.

Jenne, E.A.. "Controls on Hn, Fe, Co, Ni, Cu, and Zn Concentrations in Soils and Nater: The Significant Role of Hydrous $n$ and Fe Oxides," Advanced Chemistry. 73:337-387 (1968).

Jones, J.R.E.. "Antagonism Between Salts of the Heavy and Alkaline-Earth Metals in Their Toxic Action on the Tadpole of the

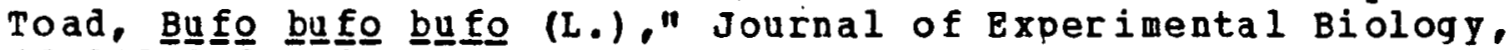
$16: 313-3 \frac{3}{3}(1939)$.

Jones, J.R.E., "The Relation Between the Electrolytic Solution Pressures of the Metals and Their Toxicity to the stickleback

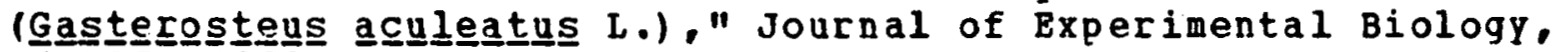
$16: 425(1939)$.

Karpevich, A.F. and A.T. Shurin, "Effect of Different Salinities and Manqanese Ion on the Survival Respiration of the Baltic Flounder [ lequrgonectes flesus trachurus (Dunker)] of the Gulf of Riga," Joureal of IChthyology, 5:753-763 (1973).

Knauer, G.A. and J.H. Martin, "Seasonal Variations of Cadmium, Copper. Manganese, Lead, and zinc in water and Phytoplankton in Monterey Bay, California," Limnology and Oceanography, 18(4) 597-604 (1973).

Kubena, M. "Resistance of Preshwater Fish Toward Potassiun Permanqanate," Water Pollution Bbstracts, 22 (July 1949). 
Lewis, M. "Fffects of Low Concentrations of Manganous Sulfate on Rags and Pry of Rainbow Trout," Progressive Fish-culturist, $38(2): 63-65(1976)$.

Iudemann, D.. "Toxicitv of Manganese to Pish, Crabs, and Animals Forming the Food of Fish," Nater Pollution Abstracts, 28:2342 (1955).

Morqan, J.J., "Chemical Equilibria and Kinetic Properties of Manaanese in Natural Vater." Principles and Applications of Water Chenistry, 4th Rudolfs Research Conference, S.D. Faust and J.V. Bunter, (eds.), Wiley, New York, pp. 561-624 (1967).

Patrick, P.M. and.M. Ioutit, "Passage of Metals in Effluents, Through Bacteria to Higher organisms," Nater Research, 10:333-335 (1976).

Patrlck, R., B. Crum, and J. Coles, "Temperature and Manganese as Determining Factors in the Presence of Diatom or Blue-Green Algal Flor as in streans," Proceedings of the National Academy of sciences, 64:472-487 (1969).

Pentreath, R.J.. "The Accumulation and Retention of $652 \mathrm{n}$ and $54 \mathrm{Mn}$ by the Plaice, Ple urgnegtes platessa L." Journal of Experimental Marine Biology and Bcology, 12(1):1-18 (1973).

Pentreath, R.J., "The Accumulation from water of $65 \mathrm{zn}, 54 \mathrm{Mn}$, 58Co, 59pe by the Mussel Mytilus edulis," Journal of the varine Bloloaical Association of the United Kingdom, 53:127-143 (1973).

Rosco, J.J. and J.W. Rachlin, "Effects of copper, zinc, Cobalt, and Manganese on the Growth of the Marine Diatom Nitzchia clostering," Bulletin of the Torrey Botanical Club, 102:100 $(1975)$.

Ruthven, J.A. and J. Cairns, Jr., "Response of Fresh-Kater protozoan Artificial Communities to Metals," Journal of protozooloqy, 2C(1):127-135 (1973).

Salzinger, K., et al., "Behavior of the Goldfish as an Early Warning system for the Presence of Pollutants in Water," Journal of Environmental Systems, 3(1):27-40 (Spring 1973).

Scheier, A. and P. Kiry, "A Discussion of the Effects of Certain Potential Toxicants on Fish and Shellfish in the Jpper Delavare Fistuary." Academy of Natural Sciences of Philadelphia, Penn. (Dec. 1973). (NTIS PB-231 423)

Shapiro, J. and G.E. Glass, "Synergistic Effects of Phosphorus and Manganese on Growth of Lake Superior Algae;" Verhandlungen Internationale fur Theoretische und Angewande limnologie. 19:395-404 (1975). 
0.S. Departwent of the Interior, "Manganese in Water - A Bibliography," Office of Water Resources Research Report HRSic 71-205, 127 Pp. (July 1971) • (NTIS No. PB 201270 )

Nolfe, D.A.. et al.. "The Flux of Mn, Fe, and $z n$ in an Estuarine Ecosystem," proceedings of the symposiun on Radioactive Contamination of the Marine Environment. International atomic. Energy Agency. Seattle, Washington, 159 pp. (1973) .

Wolfe, R.S., "uicrobial Concentration of Iron and Manganese in, Water with Low Concentrations of These Elements," Journal of the American Materworks Association, 52:1335 (1960).

\section{A ER CTRY}

Ackefors, H.. "III. Effects of Particular Pollutants. Mercury Pollution in sweden with Special Reference to conditions in the Water Habitat," Proceedings of the Royal Society of London. Series B: Biological Sciences, 177:365 (1971).

Ackefors, H., G. Lofroth, and C.-G. Rosen, "a survey of the Mercury Pollution Problem in Sweden with special Reference to Fish," Oceanography and Marine Biology Annual Review, 8:203-224 $(1970)$.

Akiyama, A., "Acute Toxicity of Tro organic Mercury Compounds to the Teleost, Oryzias latipes, in Different stages of Development," Bulletin of the Japanese society of scientific. Fisheries, $36(6): 563-570$ (1970).

Anend. D.F.. N.T. Yasutake, and R. Morgan, "Some Pactors Influencing susceptibility of Rainboy Trout to the Acute poxicity of an Ethyl Mercury Phosphate Formulation. "Transactions of the American Fisheries Society. 98:419-425 (1969).

Aubert, M. et al. "utilization of a Trophodynamic Chain of a Pelagic Type for the Study of Transfer of Metallic Pollution," Revue Internationale d'oceanographie Medicale, 28:27-52 (1972).

Aubert, M.. et al. "Ose of a Neritic Trophodynamic Chain of Molluscs for the study of the Transfer of Metallic pollutants," 6 th symposium of the Internationale d.oceanographie Hedicale, Portoroz, Yuqoslavia (Sept. 26-30, 1973): Revue Internationale d'Oceanographie Medicale, 33:7-30 (1973). (NTIS CONP-7309103-1)

Backe, C.A.. W.H. Gutenmen, and D.J. Lisk, "Residues of Total Mercury and Methylmercuric salts in Lake Trout as a Punction of Age," Science, 172:951-952 (1971). 
Barnes, H. and F.A. Standbury, "Toxic action of copper and Mercury Salts Both Separately and when Mixed on the Harpactacid Copepod Nitocㄷa spinipes (Boeck)," Journal of Experimental Biology, $25: 270-275(1948)$.

Battelle Pacific Northwest Laboratories, "A Comparison of the Lethality of various Combinations of Heavy Metals and Nater Temperature to Juvenile Rainbow Trout," 5 pp. (1973). (NTIS BNWL-SA-4704)

Baughan, G.t.. et. al.. "Chemistry of organomercurials in Aquatic Systems," Southeastern Environmental Research Laboratory, Athens, Ga.. T.S. Environmental Protection Agency, EPA-660/3-73-012 (1973).

Ben-Bassat, D. and A.M. Mayer, "Volatilization of Mercury by Algae," Physiologia Plantarum, 33:128-132 (1975).

Ben-Bassat, D., et al.. "Growth of Chlamydomonas in a Medium Containing Mercury," Nature, 240 (5375):43-44 (1972).

Betz, M., "Investiqations on the simultaneous uptake and Release

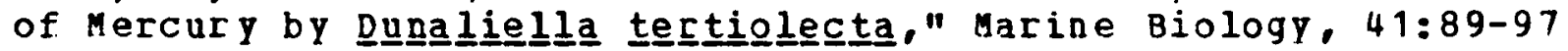
(1977).

Biesinger, K.E.. "Testimony in the Matter of proposed Toxic Pollutant. Bffluent standards for Aldrin-Dieldrin, et al.." Pederal water Pollution Control administration (307) Docket No. 1. Exhibit No. 14 (1974).

Biesinger, K.E. and G.M. Christensen, "Effects of Various Metals on Survival, Growth. Reproduction, and Metabolism of 므므hㅡㅁㅡㅡ magna," Journal of the Fisheries Besearch Board of Canada, 29(12): 1691-1700.(1972).

Binet, I. and P. Nicolle, "Influence of the salinity of the Ambient Medium on the Toxicity of Mercuric Chloride for the Stickleback," Water Pollution Abstracts, Vol. 15 (Jan. 1942).

Birge, W.J. and J.J. Just, "Sensitivity of Vertebrate Embryos To Heavy Metals as a Criterion of Water Quality," Kentucky Nater Besources Institute, Lexington. (1973). (NTIS PB-226-850)

Birqe, W.J., et al.." "Sensitivity of Vertebrate Embryos to Heavy Metals as a Criterion of Nater quality. Phase I, " Kentucky Nater Pesources Institute, Lexington (1974). (NTIS PB-226-850/LL)

Birge, H.J., et al.., "Embryopathic Effects of Naterborne and Sediment-Accumulated Cadmium, Mercury, and zinc on Reproduction and Survival of Fish and Amphibian populations in Kentucky," Research Report 100, Water Resources Research Institute, University of Kentucky, Lexington, 28 pp. (1977); OWRT/A-061-KY(1), U.S. Department of Commerce, NTIS, sprinqfield, Va. (1977). 
Bishop, J.N. and B.P. Neary, "The Form of Mercury in Preshwater Fish," Proceedings of the International Conference on Transport of Persistent Chemicals in Aquatic Ecosystems, May 1-3, 1974, Ottawa, National Research Council of Canada, Pp. III(25) -
III(29) (1974).

Bisogni, J.J., JI. and A.H. Lavrence, "Kinetics of Microbially Mediated Methrlation of Mercury in Aerobic and Anaerobic aquatic Environuents," Cornell University. Mater Resources and uarine Sciences Center. Ithaca, N. Y.. Technical Report 63; submitted to Office of Water Resources Research, O.S. Department of the Interior, Hashington, D.C., 180 pp. (Hay 1973).

Bisoqni, J.J.. Jr. and A.N. Lawrence, "Kinetics of Mercury Methvlation in Aerobic and Anaerobic Aquatic Environments," Journal of water Pollution Control Federation, 47(1): 135-152 (1975).

Blanton, M.G.. C.J. Blanton, and M.C. Robinson, "Ecological Impact of Mercury Discharge on an Enclosed Secondary Bay," Fort Dorth, Texas, Environmental Monitors, 231 pp. (1972).

Bliqh, E.G., "Mercury and the Contamination of Freshwater Fish," Journal of the Fisheries Research Board of Canada. MS Report No. 1088,27 pp. (1970).

Boetius, J., "Lethal Action of Mercuric Chloride and Phenplmercuric acetate on Fishes," Nater Pollution Abstracts, 34:1742 (1961).

Boney, A.D.. "Sublethal Effects of Mercury on Marine Algae," Marine Pollution Bulletin, 2(5):69-71 (1971).

Bothner, H.H. and R. Carpenter, "Sorption-Desorption Reactions of Mercury with Suspended Matter in the Columbia River," Presented at the International atomic Energy agency symposium on the Interaction of Radioactive Contaninants with the Constituents of the Marine Environment, Seattle, (July 10-14, 1972).

Brkovic-poporic, I. and H. Popovic, "Effects of Heary Metals on Survival and Respiration Rate of Tubificid Horms: Part I Fffects on Survival," Environmental Pollution, 13:65-72 (1977).

Brkoric-poporic. I. and M. Popovic, "Effects of Heary Metals on Survival and Respiration Rate of Tubificid Norms: Part II Effects on Respiration Rate," Environmental pollution, 13:93-98 (1977).

Buhler, D.R., (ed.). "Hercury in the Western Environnent," Proceedings of a Workshop. Portland, Ore.. Feb. 25-26, 1971, Continuing Education Publications, Corvalis, ore., 360 pp. (1973). 
Buikema, A.L., JI., J. Cairns, Jr., and G.W. Suliivan,

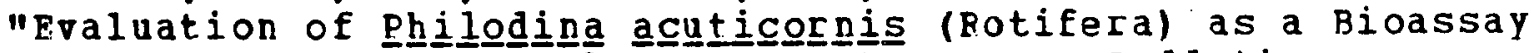
organism for Beavy Metals," Water Resources Bulletin, $10(4): 648-661$ (1974).

Burkett, R.D.. "Influence of Temperature on Dptake of

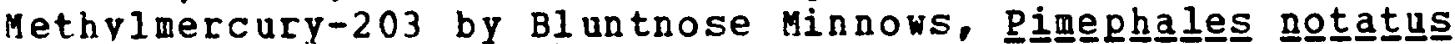
(Rafinesque)," Bulletin of Bnvironmental Contamination and Toxicology, 12:703 (1974).

Burkett, R.D.; "Optake and Release of Uethylmercury-203 by

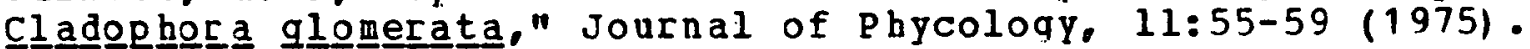

Burrows, W.D. and P.A. Krenkel, "Studies on Optake and Loss of Methylmer cury-203 by Bluegills (Lepomis macrochㅡ드는 Rafinesque)." Environmental Science and Technology, 7(13):1127-1130 (1973).

Burrows, R.D.. K.I. Taimi, and P.A. Krenkel, "The Optake and Loss of Methylmercury by Freshwater Fish," In: Congreso Internacional del Mercurio, Analysis, Contamination, Biological Effects, Applications and Miscellaneous, Proceedings of Symposium, Barcelona, Spain, pp. 283-291 (May 6-10, 1974).

Calabrese, A.. et al., "Effects of Cadmium, Mercury and Silver on Marine Animals," Marine Fisheries Review, 39:5 (1977).

Calabrese, A., et al.. "Survival and Growth of Bivalve Iarvae under Heavy-Metal stress," Marine Biology, 41:179-184 (1977).

Carter. J.W. and I.L. Cameron, "Toxicity Bioassay of Heavy Metals

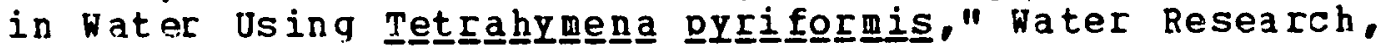
$7(7): 951-961(1973)$.

Cheremisinoff, P. and. Y. Habib, "Cadmium, Chromium, Lead, and Mercury - Plenary Account for Hater Pollution I. Occurrence, Toxicity, and Detection," Hater and Sewage Norks, 119:73 (1972).

Childs, E.A., et al.. "Exposure of Dogfish Shark Fetuses to Mercury," Bulletin of Environmental Contamination and Toxicology. $9(5): 276(1973)$.

Christensen, G.M.. "Effects of Metal Cations and Other Chenicals Upon the in ritrso Activity of $T$ wo Enzymes in the Blood Plasma of

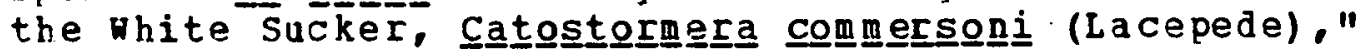
Chemica 1-Biological Interactions. 4:351-361 (1971).

Christensen, G.M.. "Biochemical Effects of Methylmercuric Chloride, Cadmium Chloride and Lead Nitrate on Embryos and Alerins of the Brook Trout, salvelinus fontinaliis. "Toxicology and pplied Pharmacology, 32:191 (1975).

Colwell, R.R. and J.D. Nelson, "Metabolism of Mercury Compounds in Microorganisms," EPA-600/3-75-007 (1975). 
Conner, P.M., "Acute Toxicity of Heavy Metals to some Marine Larvae," Marine Pollution Bulletin, 3(12):190-193 (1972).

Corner, E.D.S. and F.H. Rigler, "Modes of Action of Toxic Agents

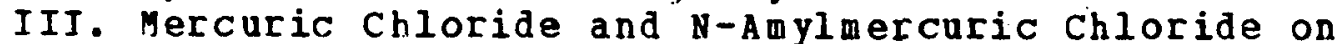
Crustaceans," Journal of the Marine Bioloqical Association of the United Kingdom, 37:85-96 (1958).

Corner, E.D.S. and B.W. Sparrow, "Hodes of Action of Toxic Agents I. Observation of the Poisoning of Certain Crustaceans by Copper and Meccury." Journal of the Marine Biological Association of the United kingdom, 35:531-548 (1956).

Corner, E.D.S. and B.H. Sparrow, "Modes of Action of Toxic Agents II. Factors Influencing Toxicities of Mercury compounds to Certain Crustacea," Journal of the Marine Biological association of the United Kingdom, 36:459-472 (1957).

Curtis, B.H.. "Influence of Temperature and Methylmercury Chloride Concentration on the Direct optake of Methylmercury

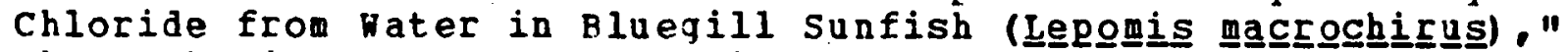
Ph.D. thesis, Northwestern Oniversity, Evanston, Ill.. 188 PP. $(1974)$.

Danie1, J.W.. "The Biotransformation of Organomercury Compounds," Proceedings of the Biochemical Society. Biochemical Journal, $130: 64 p-65 p(1972)$.

Davies, A.." "The Growth Kinetics of Isochngysisis gạlbạna in Cultures containing sublethal concentrations of Mercuric Chloride," Journal of the Marine Biological association of the onited Kingdom, 54 (1): 157-169 (1974).

Davies, A., "An Assessment of the Basis of Mercury Tolerance in Duna liél la tertiolectą." Journal of the Marine Biological Association of the United kingdom, 56:39-57 (1976).

DeCoursey. D.J. and W.B. Vernberg, "Effect of Mercury on Survival. Metabolism, and Behavior of Larval 므a pugiílatoror (Brachyura)." Oikos, 23:241-247 (1972).

D'Itri, F.M.. "The Environmental Mercury Problem," Chemical Rubber Co. Press, Cleveland, 124 pp. (1972).

D'Itri, P.M.. "Mercury in the Aquatic Ecosystem," In: Bioassay Techniques and Environmental Chemistry, G.E. Glass, (ed.), Ann Arbor Science Publishers, Ann Arbor, Mich.. pp. 3-60 (No Date).

Dorn. P.. "The Effects of Mercuric Chloride Upon Respiration in

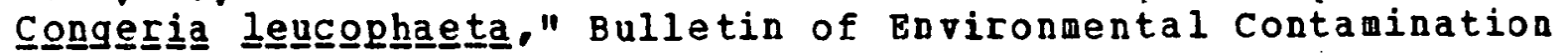
and Toxicology, $12(1): 86-91$ (1974). 
Drummond, R.A., G.F. Olson, and A.R. Batterman, "Cough Response

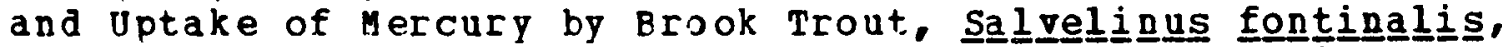
Exposed to Mercuric Compounds at Different Hydrogen-ion Concentrations," Transactions of the American Fisheries society, $103(2): 244-249$ (1974).

Bisler, R. and R.J. Hennekey, "Acute Toxicities of Cd2+, Cr6+, Hg2+, Ni2t and Zn2t to Estuarine Macrofauna," Archives of Environmental Contamination and Toxicology, 6:315-323 (1977).

Bly, R.B.. "Methylmercury Poisoning in Fish and Human Beings," Modern Medicj.ne, 135 (Nov. 1970).

Eriksson, C. and D.C. Mortiuer, "Mercury optake in Rooted Higher Aquatic plants," Verhandlungen. Internationale Vereinigung fur Theoretische und Angewunde Limnologie, 19:2087 (1975).

Fagerstrom, T. and B. Asell, "Methylmercury Accumulation in an quatic Food Chain. A lodel and Some Implications for Research. Planning," Ambio, 2:164-171 (1973).

Pagerstrom. T. and A. Jernelov, "Some Aspects of the Quantitative Ecology of Mercury." Water Research 6(10):1193-1202 (1972).

Fagerstrom. T...et al.. "Statistical Parameters as a Criteria in Model Evaluation: Kinetics of Mercury Accumulation in Pike, Esox lucius. " Oikos, 26:109 (1975).

Federation of sewage and Industrial wastes Associations, "Toxicity of Mercuric chloride, Chromic sulfate, and sodium Chromate in the Dilution B.0.D. Test," Sewage and Industrial Wastes, 26.(4):536-538 (1954).

Ferens, M.C.. "Impact of Mercuric Ions on Benthos and Periphyton of artifical streams," Ph.D. thesis, Oniversity of Georgia, Athens, 100 pp. (1974).

Filip, D.S. and R.I. Lynn, "Mercury accumulation by the Presh

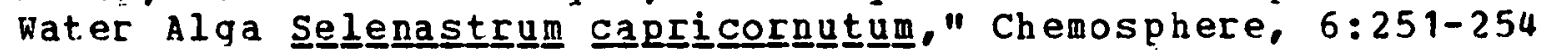
$(1972)$.

Fisheries Pesearch Board of Canada, "Mercury in the Aquatic Enviconment: A Summary of Research Carried out by the preshwater Institute 1970-1971," MS Report No. 1167, pp. 23-26 (1972):

Friberg, L. and G.F. Nordberq, (eds.), "Mercury in the Environment," Chemical Rubber Co. Press, Cleveland (1972).

Fuita, M. and K. Hashizume, "Accumulation of Mercury by Freshwater Planktonic Diatoms," Chemosphere, 1 (5):203-207

Eujita, M.. K. Iwasaki, and E. Takabatake, "Intracellular Distribution of Mercury in Freshwater Diaton, SYned ra Cells," Environmental Research, 14:1-13 (1977). 
Furukava, K. and $K$. Tonomura, "Metallic Mercury Releasing Bnzyme in Mercury Resistant Pse

Chenistry, 36:217-226 (1972).

Gaechter, R., "Heavy Metal Toxicity and Syneraism to Natural

phytoplankton in the Eutrophic Lake Alpnach and the lesotrophic Horw Bay," Schweizerische Zeitschrift fur Hydrologie, 38 (2):97 (1976).

Ganther, H.E., et al.. "Selenium: Relation to Decreased Toxicity of Methylmercury added to Diets Containing Tuna," Science, 175: 1122 (1972).

Gardner, G.R.. "Chemically Induced Lesions in Estuarine or Marine Teleosts," Pathology of Fishes, W. E. Bibelin and G. Migaki, (eds.), Oniversity of Hisconsin Press, Madison, pp. 657-693 (1975).

Gardner, W., et al., nconcentrations of Total hercury and Methyluercury ir Fish and Other Coastal orgarisms: Implications to Mercury Cycling," Mineral Cycling in Southeastern Ecosystems (1975). (NTIS CONF-74 0513)

Gatz, M.. "Investigations on the Simultaneous Optake and Release of Mercury by Duna (1977).

Gavis, J. and J.F. Ferguson, "The Cycling of Mercury Through the Environment," Nater Research, 6:989-1008 (1972).

Giblin, F.J. and E.J. Massaro, "Pharmacodynamics of Methylmercury in the Bainbow Trout (sa

Distribution and Excretion," Toxicology and Applied Pharmacology. $24(1): 81-91$ (1973).

Gillespie, D.C. and D.P. Scott, "Mobilization of Mercuric Sulfide from Sediment into Fish Under Aerobic Conditions," Journal of the Fisherjes Research Board of Canada, 28(11):1807-1808 (1971).

Glooschenko, M. "Accumulation of $203 \mathrm{Hq}$ by the Marine Diatom

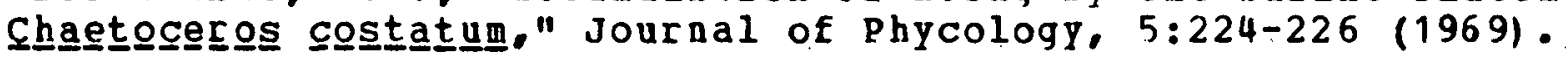

Gray. J.S.. "Synergistic Effects of Three Heavy Metals on Growth Rates of a Marine Ciliate Protozoan," In: Pollution and Physiology of Marine Organisms, F.J. Vernberg and H.B. Vernberg. (eds.). Academic Press, New York, Pp. 465-485 (1974).

Gray, J.S. and R.J. Ventilla, "Growth Rates of Sediment-Living Marine Protozoan as a Toxicity Indicator for Heavy letals," Ambio, $11(4): 118-121$ (1973).

Great Lakes Laboratory. "Chromium, Cadmium, Arsenic, selenium, Mercury, and aquatic Life: A Brief Literature Review," State University Colleqe at Buffalo, N.Y., Special Report No. 9. (1971). 
Guarino, A.M. and J.B. Anderson, "Tissue Distribution of (14C)

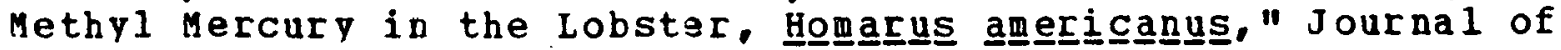
Toxicology and Environmental Health, $2: 13-24(1976)$.

Guerra, M. and N. Comodo, "Evaluation of Tolerance Limits of Some Toxic Substances in Industrial Naste Naters by the Icthyo-Toxicity Test," Bolletino della sociata Italiano di Bioloqia Sperimental, $48(22): 989$ (1972).

Hahne, H.C. and W. Kroontje, "Significance of pH and Chloride Concentration on Behavior of Heavy Metal pollutants: Mercury (II), Cadmium (JI), Zinc (II), and Lead (II)." Journal of Environmental Quality, 2:444-451 (1973).

Hahne, H.C. and W. Kroontje, "Simultaneous Effect of pH and Chloride Concentrations opon Mercury (II) as a Pollutant." proceedings of the Soil science Society of Amica, 37:838-843 $(1974)$.

Hamdy, M.K.. "Biochemical Transformation and Detoxification of Mercury in Aquatic Environment," Report No. ERC 02-77. ONRT/B-69-GA(3), U.S. Department of Commerce, NTIS, springfield,

Va. (1977).

Hannan, P.J. and C. Patouillet, "Effect of Mercury on Algal Growth Rates," Biotechnology and Bioengineering, 14:93-101 (197?).

Hannerz, L., "Experimental Investiqations on the Accumulation of Mercury in Water Crganisms," Fisheries Board of Sreden, Institute of Preshwater Research, Report No. 48, Drottningholm, Sweden, pp. $120-176(1968)$.

Hara, T.J., et al.. "Effects of Mercury and Copper on olfactory

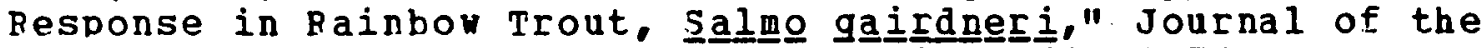
Fisheries Research Board of Canada, 33:1568 (1976).

Harriss, R.C., D.B. White, and R.B. MacFarlane, Mercury compounds Reduce Photosynthesis by Plankton," Science, 170:736-737 (1970) .

Hasselrot. T.B., "Investigations with Caged Fish as Indicators of pollution from Kraft Pulp Mills," Vattenhygien, 2:74-83 (1964).

Hasselrot, T.B. and A. Gothberg, "The Ways of Transport of Mercury to Fish," Proceedings of the International Conference on Transport of Persistent Chemicals in Aguatic Ecosystems, ottawa, ontario, May 1-3, 1974, pp. III(37) - III(47). National Research council of Canada (1974).

Heisinger. J.F. and W. Green, "Mercuric Chloride Optake by Eggs of the Ricefish and Resulting Teratogenic Effects," Bulletin of Enviconmental contamination and Toxicology. 14:665 (1975). 
Heit, M. and M. Fingerman, "The Influences of Size, Sex and Temperature on the Toxicity of Mercury to Tuo species of crayfishes," Bulletin of Environmental Contamination and Toxicology, $18(5): 572$ (1977).

Holden, A.V., "Mercury in Fish and Shellfish - A Reriev," Journal of Federal Technoloqy. 8:1 (1973).

Holderness, J., M.G. Penwick, and D.L. Lynch, "The Effect of Methyl Mercury on the Growth of the Green Alga, Coelastraum mi croporu므 Naeg. Strain 280," Bulletin of Environmental

Contamination and Toxicology, 13(3):348-350 (1975).

Holm, H. . and M.F. Cox, "Mercury in aguatic Systems:

Methylation, oxidation-Reduction, and Bioaccumulation," National

Environmental Research Center, Corvallis, ore., o.S.

Enviconnental protection Agency Report EPA-660-3-74-021, 38 pp. $(1974)$.

Huckabee, J.H. and B.G. Blaylock, "Transfer of Mercury and Cadmium from Terrestrial to Aquatic Ecosystems," Metal Ions in Biological Systems, S.K. Dhar, (ed.), Plenum, New York, pp. $125-160$ (1973) .

Huckabee, J.W. and R.A. Goldstein, "Dynamic Redistribution of Methylmercury in a Pond Ecosystem," Proceedings of the lst annual NSF Trace Contaminants Conference, Oak Ridge, Tenn, pp. 226-238 (Aug. 8-10, 1973).

Huckabee, J.M. and N.A. Griffith, "Toxicity of Mercury and

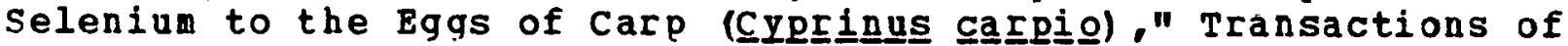
the American Fisheries Society. $103(4): 822-825$ (1974).

Hudson, K.M., "Fffects of Mercury Compounds on Algae," Ph. D: dissertation, University of Southern Mississippi, Hattiesburg. MSEP-73-016 (1973).

Hunter, W.R.. "Poisoning of Maring gammaras maiinus by Cupric Sulphate and Mercuric Chloride," Journal of Experimental Biology. $26(2): 113-124(1949)$.

Hutchinson, T.C., "Comparative studies of the Toxicity of Heavy Metals to Phytoplankton and Their Synergistic Interactions," Nater Pollution Research in Canada, 8:68-90 (1973).

Imura, N., S.K. Pan, and T. Okita, "lethylation of Inorganic Mercury ith Liver Homogenate of Tuna Fish," Chemosphere, 5:197-201 (1972). 
Jarvenpaa, T., M. Tillander, and J.K. Miettinen, "Methylmercury: Halftime of Elimination in Flounder, Pike, and Eel," presented to the Pood and agriculture Crganization Technical conference on Marine Pollution and Its Effect on Living Resources and Fishing, Rome (Dec. 9-18, 1970); Suomen Kenistilehti B., 43:439-442 (1970).

Jenkins, D.H., "Flow of Toxic Metals in the Environment," International Conference on Environmental sensing and assessment, Vol. I. Las Vegas, Nev. (Sept. 14-19, 1975).

Jenne, R.A. and W. Saunders, "Literature of Mercury: Availability of Enqlish Translations," Journal of Water Pollution Control Federation, 45:1952 (1973).

Jensen, S. and A. Jernelov. "Biological Methylation of Mercury in Aquatic Orqanisms," Nature, 223 (5207):753-754 (1969).

Jernelov, A., "Mercury Food Chains," Fnvironmental Mercury Contamination, P. Hartung and B.D. Dinman, (eds.), Ann arbor Science Publishers. Ann Arbor, Mich.. p. 174 (1972).

Jernelov, A., "Methylation by Microorqarisms in Fish Slime," Enviconmental Mercury Contamination, R. Hartung and B.D. Dinnan, (eds.). An Arbor Science Publishers, Ann Arbor, Mich.. pp. 176-177 (1972).

Johnels, A.G., et al.. "Pike (Esox lucius L.) a nd some other Aquatic organisms in Sweden as Indicators of Mercury Contamination in the Environment," Oikos, 18:323-333 (1967).

Jones, J.R.E.. "Antagonism Between Salts of the Heavy and Alkaline-Earth Metals in Their Toxic Action on the Tadpole of the

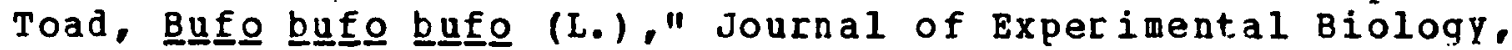
$16: 313-3 \frac{3}{3}(1939)$.

Jones, J.R.E.. "Tre Relation Between the Electrolytic Solution Pressures of the Metals and Their Toxicity to the Stickleback

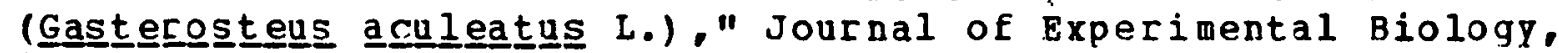
$16: 425(1939)$.

Jones, J.R.E., "The Toxicity of the Double Chlorides of Mercury and sodium $I$. Experiments with the Minnow phoxoxinus phox (I.)." Journal of Experimental Biology, 17: $325-330(1940)$.

Jones, M.B.. "Influence of Salinity and Temperature on the Toxicity of Mercury to Marine and Brackish Water Isopods (Crustacea)," Estuarine and Coastal Marine Science, 1:425-431 (1973). 
Kania, H.J., R.I. Knight, and R.J. Beyers, "Fate and Biological Effects of lercury Introduced into artificial Streams," O.S. Environmental Protection Agency. Environtental Research Laboratory, office of Besearch and Development, Athens, Ga. (Aug. 1970).

Kania, H.J.. R.I. Knight, and R.J. Beyers, "Fate and Biological Effects of Mercury Introduced into Artificial streams," Savannah River Ecology Laboratory, Aiken, S.C.. U.S. Environmental

Protection Aqency Report EPA-600/3-76/060, athens, Ga., 141 pp. (1976).

Keckes, S. and J.K. Miettinen, "A Review of Mercury as a Marine Pollutant," PAO Technical Conference on Marine pollution and its Effects on Living Resources and Fishing, Food and agriculture Organization, Rome (Dec. 9-18, 1970).

Kempf, C. and B. Sittler, "Mercury and Organochlorine Pollution in Rhine River Basin - Its Rffects Upon Bird and Fish

Populations," La Terre et la Vie (in French), 31:661. (1977).

Kendall. M. . "Acute Rffects of Methylmercury Toxicity in Channel Catfish (I Environmental Contamination and Toxicology, 13:406 (1975).

Kenda11. M. ., "Acute Effects of Methylmercury Toxicity in Chandel Catfish (I ctala Environmental Contamination and Toxicology. 18:143 (1977).

Kihlstrom, J.E. and L. Hulth, "Effect of Phenylmercuric acetate opon the Frequency of Hatching of Eggs from Zebrafish, "Bulletin of Environmental Contamination and Toxicology. 7:111-114 (1972).

Kihlstrom, J.E., C. Lundberg, and L. Hulth, "Number of Eggs and

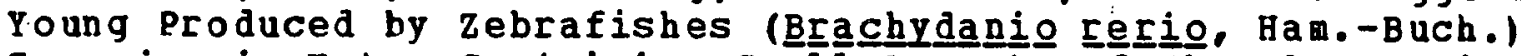
Spawning in pater Containing small aounts of phenylmercuric Acetate," Environmental Research, 4 (4):355-359 (1971).

Kin, J.H.. et al.. "Protective Action of Selenium against Mercury in Northern Creek Chubs," Bulletin of Environmental Contamination and Toxicology, 17:132 (1977).

Klaunig, J., S. Koepp, and M. McCormick, "Acute Toxicity of a Native Humichog Population (Fundulus hetergoclitiuss) to uercury." Bulletin of Rnvironmental contamination and Toxicolog. $14(5): 534-536$ (1975).

Knauer, G.A. and J.H. Martin, "Lercury in a Marine Pelagic Pood Chain," Limnology and Oceanography, 17(6):868-876 (1972).

Koelling, J.J.. "Kelationship of Trace Elements to Algae Growth," Ph.D. thesis, Washington state University, Puilman (1971). 
Kolb, L.P., et al.. "Ecological Implications of Dimethyl Mercury in an Aquatic Food Chain," U.S. Department of Commerce Report No. PB-222 971, Utah State oniversity, Logan (1973).

Koli. A.K., et al.. "Mercury Levels in Freshwater Pish of the State of South Carolina," Bulletin of Environmental Contamination and Toxicology, 17 (1):82-89 (1977).

Kudo, 1., "Hercury Transfer fron Bed Sediments to Freshwater Fish (Guppies)." Journal of Environmental ouality. 5(4):427-430 $(1976)$.

Langley, D.G.; "Mercury Methylation in an Aquatic Environment," Journal of the nater Pollution Control Federation, 45:44-51 (1973).

Lask. D.J.. et al.. "Rapid Uptake of Mercuric Ion by Goldfish," Environmental Science and Technology 5(11):1138-1139 (1971).

Laumond, F.. et al.. "Experimental Investigations, at Laboratory. on the Transfer of Mercury in Marine Trophic Chains," Revue Internationale d'Oceanographie Medicale, 31/32:47-53 (1973).

I.awrence, A.".." "Rinetics of Microbioloqically Mediated

Transformations of Heary Metals in aquatic Environments," Cornell University. Ithaca, N.Y.. (1974). (NTIS PB-239 148)

Lepple, F.K.., "Mercury in the Environment, A Global Review Including Recent studies in the Delavare Bay Region, "University of Delaware, Newark, COM-73-10620 (1973).

Linberg, S.E. and R.C. Harriss, "yercury Enrichment in Bstuarine Plant Detritus," Marine Pollution Bulletin, 5:93-95 (1974).

Iindberq. S.E. and R.C. Harriss, "Release of Mercury and organics from Resuspended Near-Shore Sediments," Journal of the water Pollution Control Federation, 49(12):2479-2487 (1977).

Lock, R.A.C., "Uptake of Methylmercury by Aquatic Orqanisms from nater and Food," In: Sublethal Effects of Toxic Chemicals on. Aguatic Aimals, J. Koeman and J. Strik (eds.), Elsevier, New York (1975).

Lockhart. W.L., "Studies on Methylmercury in Northern Pike (Esox. lucius, L.)," In: The 6th Symposium on Trace Substances in Environmental Health, D.D. Hemphill, (ed.), University of Missouri, Columbia, pp. 115-118 (1973).

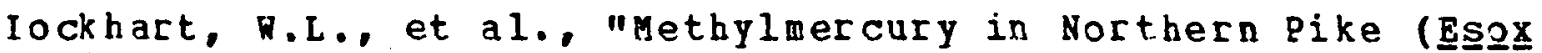
lucius : Distribution, Elimination, and Some Biochemical Character istics of Contaminated Fish," Journal of the Fisheries Research Board of Canada, 29:1519-1523 (1972). 
Luoma, S.N.. "The Optake and Interorgan Distribution of Mercury in a Carnivorous crab," Bulletin of Environdental Contamination and Toxicology, $16(6): 719-724$ (1976).

Luoma, S.N., "The Dynamics of Biologically available Mercury in a Small Estuary," Estuarine and coastal Marine Science, 5:643 (1977).

Luoma, S.N., "Physiological Characteristics of Mercury Optake by Two Estuarine Species," Marine Biology, 41:269-273 (1977).

McKim, J.M. "Testimony in the Matter of Proposed Toxic Effluent Standards for Aldrin-Dieldrin, et al.." Federal Nater pollution Control Administration (307) Docket No. 1 (1974).

MCKim, J.M., et al., "Long-term Effects of Methylmercuric Chloride on Three Generations of Brook Trout (Salvelinus

fontinalis): Toxicity. Accumulation, Distribution, and Elimination," Journal of the Fisheries Research Board of Canada, 33:2726-2739 (1976).

Mckone, C.E., et al.. "Rapid Optake of Mercuric Ion by Goldfish," Analptical Chemistry, 5(11):1138-1139 (1971).

Bacleod, J.C. and B. Ressah, "Temperature Effects on Mercury Accumulation, Toxicity, and Metabolic Rate in Rainbow Trout (Salmo ga irdneri)." Journal of the Fisheries Research Board of Canada, $30(4): 485-492$ (1973).

Majori, L. and F. Petronin, "Marine Pollution by Metals and Their Accumulation by Biological Indicators (Accumulation Pactor);" Revue Internationale d'oceanographie Medicale, 31/32:55-90 (1973).

Malacea. I.. "Contributions to the knowledge of Toxic effects of Cyanides, Ammonia, Mercury, and Arsenic on Some Fish species and on Dạphnia." studii de protectia di Epurarea Apelor, 7:751-792 $(1966)$.

Mathis, B.J. and N.R. Kevern, "Distribution of Mercury, Cadmium, Lead and Thallium in a Eutrophic Lake," Hydrobiologia, $46(2-3): 207-222$ (1975).

Matida, Y.. J.M. MCKim, et al.. "Toxicity of Mercury Compounds to Aquatic organisms and Accumulation of Compounds by the Orqanisms," Bulletin of the Freshwater Fisheries Research Laboratory, 21 (2): 197-227 (1971).

Matson, R.S.. G.E. Mustoe, and S.B. Chang, "Mercury Inhibition of Lipid Biosynthesis in Freshwater Algae," Environmental Science and Technology, $6(2): 158-160$ (1972). 
Matsui, S. and E.F. Gloyna, "Radioactivity Transport in Water-Biological Accumulation of Mercuric and Methyl Mercury by

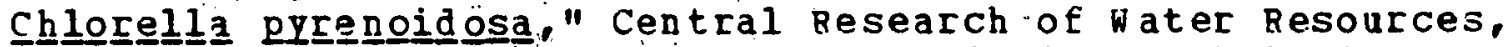
Austin, Texas, D.S. Atomic gnergy Commission Technical Report No. 22,251 pp. (1972).

Mayer, F.L. and J.L. Hamelink, "Aquatic Toxicoloqy and Hazard Evaluation," American Society for Testing and Materials, STP 634 (1977).

Mellinger, P.J.. "The Comparative Metabolism of Two Mercury Compounds as Environmental Contaminants in the Freshwater ussel,

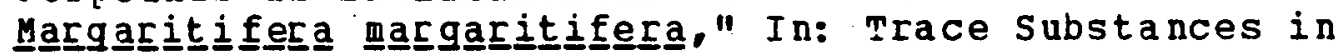
Environmental Health - VI. Proceedinqs of the Sixth Annual Conference on Trace substances in Environmental Health. University of Missouri, Columbia, June 13-15, 1972, D.D. Hemphill, (ed.), pp. 173-180 (1973).

Menasveta, P., "Effects of certain Food Aditives ón Mercury Accumulation, Distribution, and Elimination in Salmonid Pishes and Results on Growth," Ph.D. thesis, University of Nashington. seattle (1974).

Merlini, M.. et al.." "The Biological Pathwy of zinc (65Zn) in Freshwater Fish and Its Alteration by Heary Metals," Radionuclides in Ecosystems, Vol. I, D.J. Nelson, (ed.), Proceedings of the 3rd National symposium on Radioecology, Oak Ridge, Tenn., pp. 285-306 (May 10-12, 1971). (Available Erom NTIS)

Meyer, D.K.. "Effects of Mercuric Ion on Sodium Movement Through the Gills of Goldfish." Federation Proceedings, Federation of American Societies for Experimental Biology. 11:107 (1952).

Mierle, G. and P.M. Stokes, "Heavy Metal Tolerance and Metal Accimulation by Planktonic Algae," Trace Substances in Environmental Health - $X$, Oniversity of Missouri, Columbia, 113 (1976).

Miettinen, V.. et al., "Preliminary study on the Distribution and Effects of Two Chemical Porms of Methylmercury in Pike and Rainbow Trout," FAO Technical Conference on Marine Pollution and Its Effects on Living Resources and Fishing, Rome, pp. 1-12. $(1979)$.

Mills, H.L.." "Water Quality Bioassay Using selected Protozoa II. The Effects of Zinc on Population Growth of Eugleena qraci Journal of Environmental Science and Health, $1 \frac{1}{1}(8$ and 9$): 567$ $(1976)$.

Morqan, R.P., II., et al. isublethal Effects of Baltimore Harbor

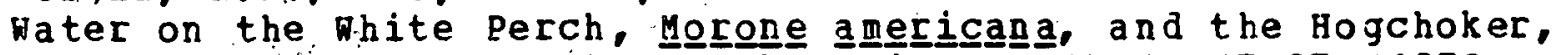

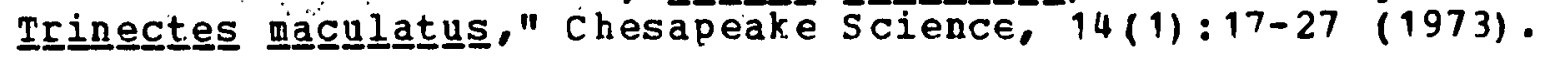


Mount, D.I., "Chronic Toxicity of Methylmercuric Chloride to the Fathead Minnow," In: Testimony in the Matter of Proposed Toxic Effluent standards for Aldrin-Dieldrin, et al.. Federal water Pollution Control administration (307) Docket No. 1, Exhibit No. $4(1974)$.

Murdock, H.R.. "Industrial Yastes: Some Data on Toxicity of Metals in wastes to Fish Life are Presented," Industrial Engineering and Chemistry, 45:99A (1953).

National Academy of Sciences, "An Assessment of Mercury in the Environaent," Report by the Panel on Mercury of the coordinating Committee for scientific and Technical assessments of

Environmental pollutants, Environmental studies Board, Commission on Natural Resources, National Research Council, Washington, D.C. (1978).

Nelson, D.A.. et al.." "Biological Effects of Heary Hetals on Juvenile Bap Scallops, Argopecten irfádians, in Short-Term Exposures," Bulletin of Environmental Contamination and Toxicology. 16:3 (1976).

Nelson, J.D., Jr., and R.R. Colvell, "Ecology of Mercury-Resistant Bacteria in Chesapeake Bay," Microbial Ecology, $1: 191$ (1975).

Nomiyama, K., "Toxicity and Physiology I. Toxicity of Heavy Metals Including Mercury," In: Heavy Metals in the aquatic Enviconment. Proceedings of a symposium at vanderbilt university. Dec. 4-7, 1973, Nashville, renn. (1973).

Noren, $K$. and G. Westoo, "Methylkvichsilver $i$ fisk," Var Poda, $2: 13-17(1967)$.

Nuzzi, R., "Toxicity of Mercury to Phytoplankton," Nature, 237 $(5349): 38-39(1972)$.

O'Connor, D.V. and P.O. Fromm, "Fffect of Methylmercury on Gill Metabolism and Elood Parameters of Bainbow Trout," Bulietin of Environmental Contamination and Toxicology, 13 (4):406-411 (1975).

office of Water Research and Technology, "Mercury in Water, A Bibliography, Volume 2," Nashington, D.C. (May 1975). (NTIS $\mathrm{PB}-242$ 940)

office of Water Pesearch and Technoloqy, "Mercury in water, A Bibliography, Volume 3," Report No. ONRT/KRSIC 77-202, U.S. Department of Commerce, NTIS, Springfield, Va. (1977).

Olson, G.F., et al.. "Mercury Residues in Fathead Minnows,

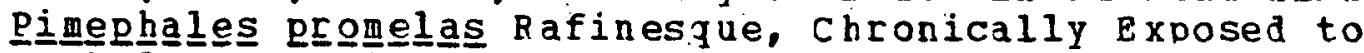
Methplmercury in water," Bulletin of Environmental contamination and Toxicology. $14(2): 129-134$ (1975). 
Olson, K.R. and R.C. Harrel, "Effect of Salinity on Acute Toxicity of Mercury. Copper, and Chromiun for Rạngia caunea (Pelecypoda, Mactridae)." Contributions in Marine Science, $17: 9-13(1973)$.

Olson, K.R.. P.O. Fromm, and W.L. Frantz, "ultrastructural Changes on hainbow Trout Gills Exposed to Methylmercury or Mercuric Chloride," Federation Proceedings, Federation of American Societies for Experimental Biology, $32: 261$ (1973).

Olsson, M." "Mercury Levels in Biota from Morrum River During a 10 Year Clean-up Period," Institute of Freshwater Research, 55:71 $(1976)$.

Overnell, J., "Inhibiti on of Marine Algal Photosynthesis by Heavy Metals," Marine Biology, 38:335 (1976).

Parizek, J., "Interactions of Selenium with Mercury, cadmium, and nther Toxic letals." Proceelings of the Symposium on Trace Element Metabolism in Animals. University of Wisconsin, Madison (1973).

Parks, G.A." "Trace Elements in Water: Origin, Fate, and control I. Mercury," National Science Foundation, Stanford University. Report of Progress, March 1, 1972-Feb. 1, 1973, Stanford, Calif.. 247 pp. (1973).

Parks, G.A., et al., "pelease, Fixation, and Transport of Mercury," Trace Elements in Water: origin, Fate, and Control I. Mercury," Progress Report, stanford Oniversity. Stanford, Calif.. 65 (1973).

Peakall, D.B. and R.J. Lovett, "Mercury: Its Dccurrence and Effects in the Ecosystem," Bioscience, 22:20-25 (1972).

Pennacchioni, A., R. Marchetti, and G.F. Gaggino, "Inability of Fish to Uethylate vercuric Chloride in vivo," Journal of Environmental Quality, $5(4): 451-454(1976)$.

Pentreath, P.J.. "The Accumulation of Mercury from Food by the

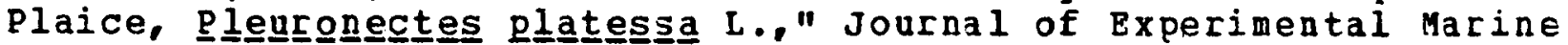
Bioloqy a nd ecology. 25:51 (1976).

Pentreath, R.J., "The Accumalation of organic Mercury from Sea water by the Plaice, Pleuronectes platesssa L." Journal of Experimental Marine Biology and Ecology, $24: 121$ (1976).

Prabhu, N.V. and.M.K. Hamdy, "Behavior of Mercury in Biosystems I. Uptake and Concentration in.Food-chain. Bulletin of Enviconmental Contamination and Toxicology, 18(4):409-417 (1977).

Ramamoorthy, S. a d D.J. Kushner, "Binding of Mercuric and other Heavy Metal Ions by Microbial Growth Media," Microbial Ecology. $2: 162(1975)$. 
Rehfus, B., A.H. Priddy, and M.E. Barnes, "Mercury Contamination in the Natural Fnvironment," Bureau of Commercial Fisheries, Ann. Arbor, Mich. (July 1970). (NTIS PB-192 910)

Rehwoldt, R.. et al., "Effect of Increased Temperature opon the Acute Toxicity of Some Heavy Metal Ions," Bulletin of

Environmental Contamination and roxicology, 8(2):91-96.(1972).

Reish, D.J., et al.. "The Effect of Heavy Metals on Laboratory Populations of. Two Polychaetes with Comparisons to the Water Quality Conditions and stanjards in Southern California Marine Waters," Mat er Research, 10:299-302 (1976).

Renfro, J.I., et al.. "Methyl Mercury and Inorganic Mercury: optake, Distribution, and Effect on Osmoregulatory Mechanisms in Fishes," In: Pollution and Physiology of Marine organisas, F.J. Vernberq and W. B. Vernherg, (eds.). Academic Press, Neu York, pp. $101-122(1974)$.

Renzoni, A. and E. Baccl, "Bodily Distribution, Accumulation, and Excretion of Mercury in a Freshwater lussel, "Bulletin of Enviconmental contamination and Toxicology, $15(3): 366$ (1976).

Ridley, W.P.. et al.. "Biomethylation of Toxic Elements in the Environment," Science, 197:329 (1977).

Rivers, J.B., J.E. Pearson, and C.D. Shultz, "Total and Organic Mercury in Marine Fish," Bulletin of Environmental contamination and Toxicology, 5:257-266 (1972).

Roales, R.R. and A. Perlmutter, "Toxicity of Methylmercury and Copper. Applied singly and Jointly to the Blue Gourami.

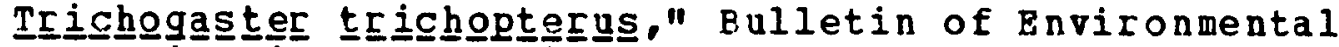

contanination and Toxicology, 12(5):633-639 (1974).

Roales, R.R. and A. Perloutter, "The Effects of Sub-Lethal Doses of Methylmercury and Copper applied Singly and Jointly, on the Immune Response of the Blue Gourami (Trichogaster tricichopterus) to Viral and Bacterial Antigens." Archives of Environmental contamination and Toxicology, 5:325-331 (1977).

Robinson, S. and W.B. Scott, "A Selected Bibliography on Hg. in the Rnvironment, with Subject listing," The Royal ontario Museum, Toronto, (1974).

Poesifadi, G.. et al.. "Survival and Chloride Ion Regulation of the Porcelain Crab petrolisthes armatus Exposed to Mercury." Marine Biology, $27: \overline{213-217}(1974)$.

Rucker, R.R. and D.F. Amend, "Absorption and Retention of organic Mercurials by Rainbow Trout and Chinook and Sockeye Salmon," Progressive Pish-Culturist, 31:197-201 (1969). 
Rzewuska, E. and A. Nernikowska-Ukleja, "Research on the Influence of Heary Metals on the Development of Scenedes quadricauda (Turp.) Breb. I. Mercury." Polskie Archiwum Hy drohiologie, 21 (1):109-117 (1974).

Salzinger, K., et al.. "Behavior of the Goldfish as an Early Narning system for the presence of pollutants in pater, "Journal of Environmental Systems, 3(1):27-40 (Spring 1973).

Sartory. D.P. and B.J. Lloyd, "The Toxic Effects of selected Heavy Metals on nnadapted Populations of Vor Var Similis," Water Besearch, 10:1123 (1976).

Scheier, A. and P. Kiry, "A Discussion of the Effects of Certain Potential Toxicants on Fish and Shellfish in the opper Delaware Estuary." Academy of Natural Sciences of philadelphia, Penn. (Dec. 1973). (NTIS PB-231 423)

Scher er, E., F.A.J. Armstrong, and S.H. Nowak, "Effects of

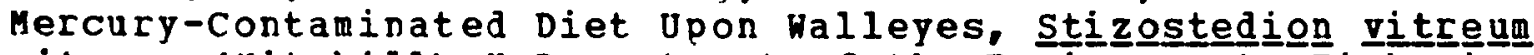
vitreum (Mitchill)." Department of the Environment, Fisheries and Marine Service Technical Report No. 597. Winnipeq, Manitoba (1975).

Schindler, J.E. and J.J. Alberts, "Behavior of Mercury, Chromiun, and Cadnium in Aquatic systems," O.S. Enviconmental protection Agency, EPA-600/3-77-023, Athens, Ga. (1977).

Scott, D.P., "Mercury Concentration of White Muscle in Relation to A ge, Growth, and Condition in Four species of Fishes from Clay Lake, Ontario," Journal of the Fisheries Research Board of Canada, $31: 1723(1974)$.

Scott, D.P. and F.A.J. Armstrong, "Mercury Concentration in Relation to size in Several species of Preshwater Fishes from Manitoba and Northwestern Ontario," Journal of the Fisheries Research Board of Canada, 29(12):1685-1690 (1972).

Shealey, M.H., Jr. and P.A. Sandifer, "Effects of Mercury on

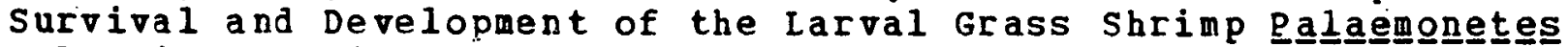
uㅡㄴaㅡ동.s." Marine Riology, 33(1):7-16 (1975).

Sick, I.B. and H.I. Windom, "Effects of Environmental Levels of Mercury and Cadmium in Rates of Metal Uptake and Growth Physiology of Selected Genera of uarine Phytoplankton." Proceedings of the Symposium on Mineral Cycling in Southeastern Ecosystems, Augusta, Ga., pD. 239-249 (1975).

Sigmon, C.F., H.J. Kania, and R.J. Beyers, "Reductions in Biomass and Diversity Resulting from Exposure to Mercury in Artificial Streams," Journal of the Fisheries Research Board of Canada. $34(4): 493-500(1977)$. 
Smith, A.I., B.H. Green, and A. Lutz, "Optake of Mercury by Freshwater Clams (family onionidae)," Journal of the Fisheries Research Board of Canada, 32 (8):1297-1303 (1975).

Sodergren, S. "Ecological Effects of Heary Metal Discharge in a Salmon River," Drottningholm, sweden. Institute of Freshwater Research, Report 55:91 (1976).

Sonntag. N.C. and H. Greve, "Investigation of the Impact of Mercury on Enclosed Water Colums Using. a Zooplankton Simulation Hodel," Journal of the Fisheries Research Board of Canada, $34: 2295$ (1977).

Spangler, W.J.. et al.. "Hethylmercury: Bacterial Degradation in Lake Sediments," Science, 180:192-193 (1973).

Sumers, A.O. and E. Levis, "Volatilization of Mercuric Chloride

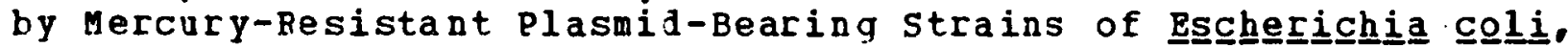

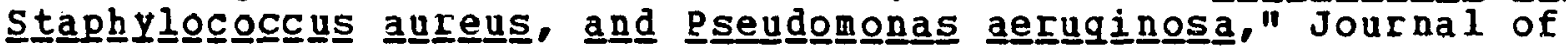
Bacteriology, 113(2): 1070-1072 (1973).

Summers, A.0. and S. Silver, "Mercury Resistance in a Plasmid-Bearing Strain of Es chher Bacteriology, $112(2): 1228-1236$ (1972).

Tarao, R., et al.. "The Accumulation of Mercury in the Fishes Reared in the sea Nater Contaminated by suspended solids Containing Mercury." (in Japanese with English Sumary), Bulletin of the Japanese Society of Scientific Fisheries, 42:1411 (1976).

Taylor, D., "A Sumary of the Data on the Toxicity of Various Materials to Aquatic Li fe," Imperial Chemical Industries, Vols. 1 and 2 (1977).

Tomoyeda, M., et al., "Recovery of Heavy Metal Compounds by Microorganisms II. Incorporation of phenylmercuric and Mercuric Acetate into Microorqanisms Tolerant to Thel," Nippon Nogei Kagaku Kaishi (in Japanese), 47:51 (1973).

Tompkins, T. and D. R. Blinn, "The Effect of Mercury on the Growth

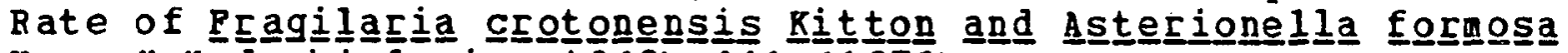
Hass," HY drobiologia, $49(2): 111$ (1976).

Tsai, S. C.. "Influence of Aguatic Environmental Factors on optake and Toxicity of Mercurials in Fish," Ph.D. thesis, oniversity of Wisconsin, Madison (1976).

Tsai, S.-C., et al. "Importance of Nater pH in Accumulation of Inorganic Mercury in Pish," Bulletin of Environmental Contamination and Toxicology. 13.(2):188-193 (1975). 
Turner, R.R. and S.E. Lindberq, "Behavior and Transport of Vercury in River-Reservoir System Downstream of Inactive Chloralkali plant." Environmental science and Technology, $12(8): 918-923(1978)$.

Ji. J.. "Mercury Pollution of Sea and Freshwater: Its Accumulation Into Nater Biomass." Revue Internationale d'Oceanographie Medicale, 22/23:79-128 (1971).

n.S. Department of the Interior, "Mercury in Water - A Bibliography." Vol. I. , Office of Water Resource Research Report WRSIC 72-207, 294 pp. (Jan. 1972) . (NTIS PB-206-535)

U.S. Department of the Interior, "Mercury in Water - A Bibliography," Vol. II.. Office of Water Research and Technology Report OWRT/RRSIC 75-203, $308 \mathrm{pp}$. (May 1975) . (NTIS PB-242-940)

U.S. Department of the Interior, "Mercury in Water - A Bibliography," Vol. III., Office of Nater Research and Technology Report owRT/WRSIC 77-202, 159 pp. (April 1977). (NTIS PB-267-079)

Uthe, J.F., F.M. Atton, and I.M. Royer, "Uptake of Mercury by Caged Rainbow Trout (Salimo gaiirgneri) in the South Saskatchewan River." Journal of the Fisheries Research Board of Canada, $30(5): 643-650$ (1973).

Varanasi, II. P.A. Robisch, and D.C. Malins, "Structural Alterations in Fish Eoidermal Mucus Produced by waterborne Lead and vercury," Nature, 258(5534):431-432 (1975).

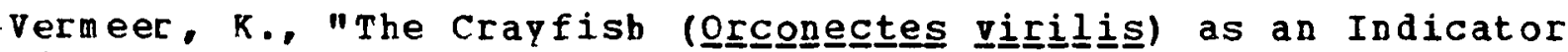
of Mercury Contamination," Canadian Field Naturalist. $86(2): 123-126$ (1972).

vernberg. W.B.. "Synergistic Effects of Temperature, Salinity. and Mercury on Survival and Metabolism of the Adult Fiddler Crab,

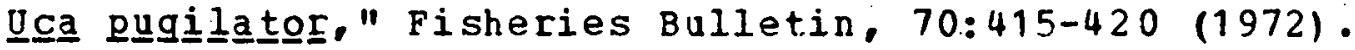

Vernberq, W. B. and J. O'Hara, "Temperature-Salinity stress and Mercury optake in the Fidaler Crab, Jca pugi latoor, "Journal of the Fisheries Research Boart of Canada, 29(10):1491-1494 (1972).

Walker, J.D. and R.R. Colvell, "Mercury-Resistant Bacteria and Petroleum Degradation," Applied Mic:robioloqy. 27(1):285-287 $(1974)$.

Weis, J.S. and P. Weis, "Effects of Heary Metals on Development

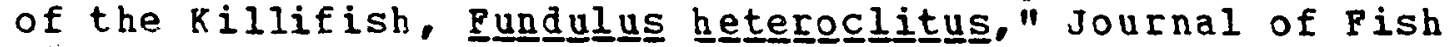
Biology, 11:39 (1977).

Weisbart, M.. "Distribution and Tissue Retention of Mercury-203

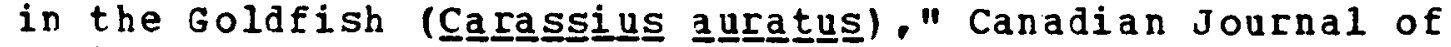
Zooloqy, 51:143-150 (1973). 
Hier, P.A. and C.H. Hine, "sffects of Various letals on Behavior of Conditioned Goldfish." Archives of Environmental Health. $20(1): 45-51(1970)$.

Williams, P.M. and H.V. Weiss, "Mercury in the Marine Environment: Concentration in sea Water and in a Pelaqic Food Chain." Journal of the Fisheries Research Board of Canada, $30(2): 293-295$ (1973).

Wintom, H., et al., "The Bole of Methylmercury production. in the Transfer of Mercury in a Salt Marsh Ecosystem," Estuarine and Coastal Marine Science, 4:579-583 (1976).

Nisely, B. and R.A.P. Blick, "Mortality of Marine Invertebrate Larvae in Meccury. Copper, and Zinc Solutions," Australian Journal of Marine and Freshwater Research, 18(1):63-72 (1967).

Wobeser, G., "Acute Toxicity of Methylmercury Chloride and Mercuric Chloride for Rainbow Trout (Salno ga ir Finqerlings," Journal of the Fisheries Research Board of Canada, $32: 2005(1975)$.

Hobeser, G., "Prolonged Oral Administration of Methylmercury Chloride to Rainbow Trout (sallmo gair of the Fisheries Research Board of Canada, 32:2015 (1975) .

Wood, J.M.. "Metabolic Cycles for Toxic Elements in aqueous Systems," Revue Internationale d 'Oceanographie Medicale, 31/32:7-16 (1973); Bioloqical Abstracts, 58:46415 (1974).

Yamanaka, S, and. K. Ueda, "High Ethyl-Mercury in River Fish by Man-made Pollution," Bulletin of Environmental Contamination and Toxicology, 14:469 (1975).

Yasunaqa, Y.." "The Influence of Some Pollutants on the Survival of Egqs and Larvae of Two Species of Flatfish, Limang da yokahangae

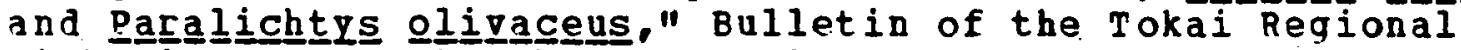
Fisheries Research Laboratory (in Japanese). (86):81-112 (1976).

Zeller, H.D. and J.H. Finqer, "Investigations of Mercury Pollution in the Aquatic Environgent of the Southeastern United states," Presented at the 10th Annual Environmental and Nater Resources Engineering Conference, Nashville, Tenn. (June 3-4, 19711 .

\section{MOL YBDENOM}

Abbott, 0.J.. "The Toxicity of Amonium Molybdate to Marine Invertebrates," Marine Pollution Bulletin, 8:204 (1977). 
Bringmann, G. and R. Kuhn. "The Toxic Effects of waste Water on Aquatic Bacteria, Algae, and Small Crustaceans," Gesundheits-Ingenieur, 80:115 (1959).

Brkovic-poporic, I. and M. Popovic, "effects of Heavy Metals on Survival and Respiration Rate of Tubificid worms: Part. I Effects on Survival," Environmental Pollution, 13:65-72 (1977).

Brown, V.M., "Aspects of Heary Metals Toxicity in Fresh Waters," Proceedings of the International Joint Commission's Norkshop on Toxicity to Biota of Metal Porms in Natural Nater, october 7-8, 1975, Dulutb, Minn., pp. 59-75 (April 1976).

Chappe11, R.R. and R.K. Petersen, (eds.), "Molybdenum in the Environment (in Two Volumes)," Proceedings of an International Symposium on Molybdenum in the Environment, Marcel Dekker, Inc., New York (1976).

Colmano, G., "Molybdenum Toxicity: Abnormal Cellular Division of Teratogenic Appearance in Euglena graciㅣㄹㅗ. " Bulletin of

Environmental Contamination and Toxicology, 9 (6):361-364 (1973).

Cordone, A.J. and S.J. Nicola, "The Influence of Molybdenum on the Trout and Trout Pishing of Castle Lake," California Pish and Game, $56(2): 96-108$ (1970).

Easterday, R.I. and R.F. Miller, "Acute Toxicity of Molybdenum to the Bluegill," Proceedings of the Virginia Journal of Science, pp. 199-200 (1963).

Peterson, J.R.. (ed.). "Molybdenum and Pish," Industrial Water and Engineering, $11(3): 6$ (1974) .

Sharenkova, K. and K. Gabrovski, "Effect of Molybdenum Phosphate Glàsses Containing Trace Rlements on the productivity of

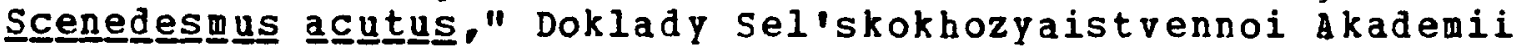
(USSR), $6: 1 \frac{1}{(1973)}$.

Tarzwe11, C.M. and C. Benderson, "Toxicity of Some of the Less Common Metals to Fishes," Transactions of the seminar on Sanitary Engineering Aspects of the Atomic Energy Industry, Robert A. Taft Engineering Center Report. TID-7517 (1956).

Halker, J.B., "Inorganic Micronutrient Requirements of chllorellia. I. Requirements for Calcium (or Strontium). Copper, and Molybdenuw," Archives of Biochemistry and Biophysics, 46:1-11 (1953).

Ward, J.V., "Molybdenum Concentrations in Tissues of the Rainbow

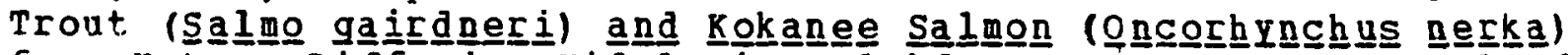
from Waters Differing widely in Molybdenum content, "Journal of the Fisheries Research Board of Canada, 30:841-842 (1973). 
NICKEL

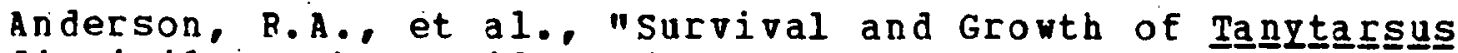
dissimilas (Chronomidae). Bxposed to Copper, Cadmium, Zinc, and Nickel," National Envi conmental Research Laboratory, Duluth. Minn.. Quarterly Reports (1975).

Ashton, M.M., "Nickel Pollution," Nature, 237:46-47. (1972).

Biesinger, R.E. and G.M. Christensen, "Effects of Various Metals on Survival, Growth, Reproduction, and Metabolism of Dạphnnia 뜸q므. " Journal of the Fisheries Research Board of Canada, 29(12): 1691-1700 (1972).

Brkovic-Poporic, I. and M. Poporic, "Effects of Heavy Metals on Survival and Respiration Rate of Tubificid Norms: Part I Effects on Survival," Environmental Pollution, 13:65-72 (1977).

Brkovic-Popovic, I. and M. Popovic, "Effects of Heary Metals on Survival and Respiration Rate of Tubificid Norms: Part II -

Fffects on Respiration Rate," Environmental Pollution, 13:93-98 (1977).

Broderius, S.J.. "Determination of Molecular Hydrocyanic acid in water and Studies of the chemistry and Toxicity to Fish of the Nickelocyanide Complex," M.S. thesis, Oregon state oniversity, Corvallis (1970).

Brown, V.M., "The Calculation of the Acute Toxicity of Mixtures of Poison to Rainbow Trout," Nater Research, 2(10):723-733

$(1968)$.

Brown, V.M. and R.A. Dalton, "The Acute Lethal Toxicity to Rainbow Trout of Mixtures of Copper, Phenol, Zinc and Nickel," Journal of Fisheries. Biology, 2:211-216 (1970).

Buikema, A.I.. Jr., J. Cairns, Jr., and G.W. Sullivan,

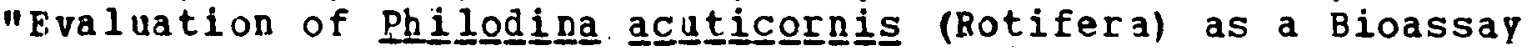
orqanism for Heavy Hetals," Water Resources Bulletin, $10(4): 648-661(1974)$.

Calabrese, A.. et al.. "Toxicity of Heavy Metals to Embryos of

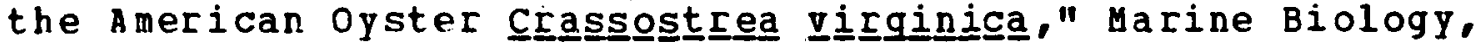
$18: 162-166$ (1973).

Calabrese, A., et al., "Survival and Growth of Bivalve Larvae under hearp-Metal Stress," larine Biology, 41:179-184 (1977).

Corbet, A.B., C. Wirsen, and G.E. Jones, "Effect of Nickel on a

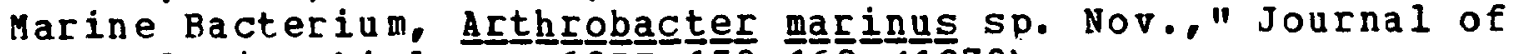
General Microbiology. 62 IJ:159-169 (1970). 
Doudoroff, P., G. Luduc, and C.R. Schneider, "lcute Toxicity to Fish of Solutions Containing Complex Metal Cyanides, in Relation to concentrations of Molecular Hydrocyanic acid." Transactions of the American Fisheries Society, 95(1):6-22 (1966).

Eisler, R.. "Acute Toxicities of Selected Heavy Metals to the Softshell Clam, yㅡㅁ a Contamination and Toxicology, 17:137 (1977).

Friedrich, A.R. and F.P. Filice, "optake and Accumulation of the Nickel Ion by 1 ytilus edulíis," Bulletin of Environmental Contamination and Toxicology, 16(6):750-756 (1976).

Hutchinson, T.C., "Comparative studies of the Toxicity of Heavy Metals to Phytoplankton and Their Synergistic Interactions," water Pollution Research in Canada, 8:68-90 (1973).

Hutchinson, T.C. and H. Czyrska, "Heavy Metal Toxicity and synergism to Ploating Aquatic weeds," Verhandlungen Internationale Vereiniqung fur Theoretische und Angewunde Limnoloqie, 19:2102-2111 (1975).

Jenkins, D.W., "Flow of Toxic Metals in the Environment," International Conference or Environmental Sensing and Assessuent, vol. I, Las Vegas, Ner. (Sept. 14-19, 1975).

Jenne, E.A., "Controls on Mn, Fe, Co, Ni, Cu, and Zn Concentrations in Soils and vater: The Significant Role of Hydrous Mn and Fe Oxides," Idvanced Chemistry, 73:337-387 (1968).

Kerfoot, W.B. and G.A. Redmann, "Permissible Ievels of Heavy Metals in Secondary effluent for Use in a Combined sewage Treatment-Marine Agriculture System II. Development of Guidelines by Method of Additions," proceedings of the conference on wastewater ose in the production of Pood and Fiber, oklahoma city, okla.. pp. 79-101 (March 5-7, 1974).

Paschal, D.C. and W. McNamara, "uptake of Cadmium and Nickel by Salviniag," Transactions of the Illinois state Academy of Science, 68:132 (1975).

Pickering, O.H.: "Chronic Toxicity of Nickel to the Fathead Minnow," Journal of the Water Pollution Control Federation. $46(4): 760-765 \quad(1974)$.

Pickerjng, Q.H. and C. Henderson, "Acute Toxicity of Some Heavy Metals to Different Species of Warm Hater Pishes," International Journal of Air and yater Pollution, 10:453-463 (1966).

Poon, C.P.C. and K.H. Bhayahi, "Metal Toxicity to sewage Organisms," Proceedinas of the American Society of Civil Engineers, Journal of the Sanitary Engineering Division, Vol. 97 (1970). 
Rehwoldt, R.. G. Bida, and B. Nerrie, "Acute Toxicity of Copper, Nickol and Zinc Ions to Some Hudson River Fish Species," Bulletin of Pnvironmental Contamination and Toxicology, $6(5): 445-448$ (1971).

Scheier, A. and P. Kiry. "A Discussion of the Effects of Certain Potential Toxicarts on Fish and Shellfish in the Upper Delaware Estuary," Acadeny of Natural Sciences of Philadelphia. Penn. (Dec. 1973). (NTIS PB-231423)

Sodergren. S., "Ecological effects of Heary Metal Discharge in a Salmon River," Drottningholm, Sweden, Institute of Preshwater Research, Report 55:91 (1976).

Stokes, P.M., "uptake and Accumulation of Copper and Nickel by Metal-Tolerant strains of scenedesmus," Verhandlungen Internationale vereinigunq $f u r$ Theoretische und Angewandte Iimnoloqie, 19:2128-2137 (1975).

Stokes, P.M.. "Adaptation of Green Algae to High Levels of Copper and Nickel in Aguatic Environments." International Conference on Heavy Metals in the Environment, Vol. II. Pathways and Cycling. Institute of Environmental Studies, Mniversity of Toronto, 137 (1977).

Tabata, K.. "Studies on the Toxicity of Heavy Metals to Aquatic Animals and the Factors to Decrease the roxicity $I$. on the Formation and the Toxicity of Precipitates of Heavy Metals," Bulletin of Tokai Regional Fisheries Research Laboratory, $58: 203-214$ (1969).

Tabata, K.. "Studies on the Toxicity of Heavy Metals to Aquatic Animals and the Pactors to Decrease the Toxicity II. Art-7nnistis Artion of yardnoss componorts ir water on the "oxicity of Heavy Metal Ions," Bulletia of roiai Reyional Fisheries Research Laboratory, 58:215-232 (1969).

Tabata, K.. "Studies on the Toxicity of Heary Metals to Aquatic Animals and the Factors to Decrease the Toxicity IV. on the Relation Between the Toxicity of Heary Metals and the ouality of Environmental Nater," Bulletin of Tokai Regional Fisheries Research Laboratory. 58:243-253 (1969).

Trollope, D.R. and B. Evans, "Concentrations of Copper, Iron, Lead, Nickel and Zinc in Freshwater Algal Blooms," Environmental Pollution, 11:109-116 (1976).

0.S. Environmental protection Agency, "preliminary Investigation of Effects on the Environment of Boron, Indium, Nickel, Selenium, Tin, Vanadium and Their Compounds III. Nickel," U.S. EPA Report EPA $560 / 2-75 / 005 C$ (Auq. 1975). (NTIS PB-245 986/5ST) 
U.S. Bnvironmental Protection Agency, "Quality criteria for Water," Office of Hater Planning and Standards Report EPA 440/9-76/023,537 pp. (1976). (NTIS PB-263943/3ST).

Warnick, S.L. and H.L. Bell, "Acute Toxicity of Some Heary Metals to Different Species of Aguatic Insects," Journal of the llater pollution Control Federation, 41(2):280-284 (1969).

Whitley, I.S. and R.A. Sikora, "Effect of Three Common Pollutants on the Respiration Rate of Tubificid Horms," Journal of the Hater Pollution Control Federation, Part 2, pp. R57-R66 (1970).

pH

Baas-Becking, L.G.M.. I.R. Kaplan, and D. Moore, "Limits of the Natural Environment in Terms of $\mathrm{pH}$ and oxidation-Reduction Potentials," Journal of Geology, 68:243-284 (1960).

Beamish, R.J., "Lethal pH for the white Sucker (Catosostomus commersong society. 101:355-358 (1972).

Bell. H.L.. "Effects of $\mathrm{pH}$ on the Life cycle of the Midge, Tanytarssus dissimilis." Canadian Entomology, 102(5):636-639 (1970).

Bell, H.L.. "Effect of Low pH on the Survival and Emergence of Aquatic Insects," Water Res sarch, 5:313-319 (1971).

Bell. H.L. and A. V. Nebeker, "Preliminary Studies on the Tolerance of Aquatic Insects to Low pH," Journal of the Kansas Entomological Society, 42 (2):230-236 (1969).

Bisoqni, J.J., Jr. and A.W. Lawrence, "Kinetics of Mercury Methylation in Aerobic and Anaerobic Aquatic Environments," Journal of Water Pollution Control Federation, 47 (1): 135-152 (1975).

Boyer, J.F. and V.E. Gleason, "Coal and Coal Mine Drainage," Journal of the Water Pollution Control Federation, $49(6): 1163-1172$ (1977).

Broderius, S.J. and I.L. Smith, Jr., "Effect of Hydroqen sulfide on Fisb and Invertebrates II. Hydrogen sulfide Determination and Relationship Between $\mathrm{pH}$ and Sulfide Toxicity," U.S. Environmental protection Agency Report EPA-600/9-76/062b (1976).

Brown, V.M.. "The Calculation of the Acute Toxicity of Mixtures of Poison to Rainbow Trout," Nater Research, 2(10):723-733

(1968). 
Brown, V.M., "Aspects of Heavy Metals Toxicity in Fresh Waters," proceedings of the International Joint Commission's Workshop on Toxicity to Biota of letal porms in Natural water, October 7-8, 1975. Duluth, Minn.. pp. 59-75 (April 1976).

Brunqs, H.A., et al... "Effects of Pollution on Freshuater Fish," Journal of the Water pollution control Federation.

$49(6): 1425-1493$ (1977).

Cairns, J., Jr., et al., "The Effects of pH, solubility and Temperature opon the Acute roxicity of Zinc to the Bluegill

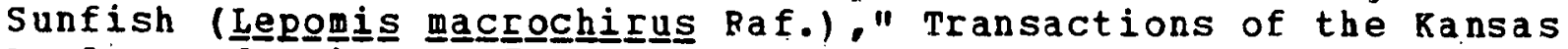
Academ of Science, $74(1): 81-92$ (1971).

Calabrese, A. and H.C. Davis, "pH Tolerance of Embryos and Larvae

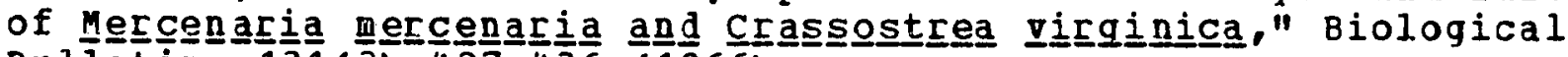
Bulietin, $131\left(\frac{1}{3}\right): 427-4 \frac{1}{6}(1966)$.

Chapman, G.. "Effect of Heary Metals on Fish," Oreaon state Universit $Y$ Water Resources Research Report NO. SENN-NR-D16.73, pp. 141-162 (Jan. 1973).

Chipman. W.A.. "Role of $\mathrm{pH}$ in Determining the Toxicity of Amonium Compounds," Water pollution Abstracts, Vol. 18 (March/April 1945).

Creaser, C.n.." "Belative Importance of Hydrogen Ion, Temperature, Dissolved Oxygen, and Carbon Dioxide Tension on Habitat Selection by Brook Trout," Ecology, 11:246-262 (1930).

Dauqherty, A.M. and L.C. Attman, "Influence of Hydrogen Ion Concentration. Salinity, and Oxygen upon the Rheotaxis of Some Marine Fish," Publishings of the Puget Sound Marine Biology station, 3:365-368 (1925).

Daye, P.G. and E.T. Garside, "Lethal Levels of pH for Brook Trout, Sa 1 velelinus fontinalis (Mitchill)," Canadian Journal of Zoolo gy. 53:639-641(1975).

Daye, P.G. and E.T. Garside, "Histopathologic Changes in Surficial Tissues of Brook Trout, salvelingus fongtingalis (Bitchill). Exposed to Acute and Chronic Levels of pH," Canadian Journal of Zoology, 54:2140-2155 (1976).

Doudoroff, P., G. Luduc, and C.R. Schneider, "Acute Toxicity to Fish of Solutions containing Complex Metal cyanides, in Relation to Concentrations of Molecular Hydrocyanic Acid," Transactions of the merican Fisheries Society, 95 (1):6-22 (1966).

Drummond, R.A., G.F. Olson, and A.R. Batterman, "Cough Response

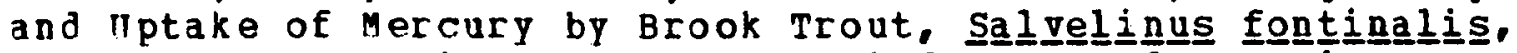
Exposed to Mercuric compounds at Different Hydroqen-ion Concentrations," Transactions of the American Fisheries society. $103(2): 244-249$ (1974). 
Dyk, V.. "Ability of Fish to Resist Fluctuations of pH Values and to Becover from Damage by Acidified Nater," Nater Pollution Abstracts, Vol. 17 (1940).

Emerson, K.. et al.. "Aqueous Amonia Equilibrium Calculations: Effect of $\mathrm{pH}$ and Temperature," Journal of the Pisheries Research Board of Canada, $32(12): 2379-2383$ (1975).

Emigh, 月.C.. "Alqae Growth Raises $\mathrm{pH}$ of Hater. Some Observations at the Costesville Water Works," Waterworks and Sewerage, 81:275 $(1935)$.

European Inland Fisheries Advisory Commission, "Water Quality Criteriz for European Freshwater Fish, Report on Extreme pH Values and Inland Fisheries," Water Research, 3:593-611 (No datel.

Everhart, W.H. and R.A. Freeman, "Effects of Chemical Variations in Aquatic Environments: Volume II. Toxic Effects of Aqueous Aluminum to Rainbow Trout." 0.S. Environmental Protection agency Report EPA-R3-73-0116 (1973). (NTIS PB-221 344).

Falk, D.L. and W.A. Dunson, "The Effects of Season and Acute Sub-Lethal Exposure on Survival Times of Brook Trout at Low pH," water Research, 11 (1):13-15 (1977).

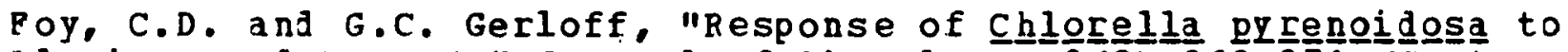
A luminum and Low pH," Journal of Phycology. $8(3): 268-271$ (Sept. 19721 .

Fremling, C.R., "Acute Toxicity of the Lampicide 3-Trifluoromethyl-4-Nitrophenol (TFM) to Nymphs of Mayflies (Hexagenia sp.)." Investigations in Fish control, U.S. Department of the Interior, Fish and Wildlife service, Nashington, D.C. (1975).

Hahne, H.C. and H. Kroontje, "Significance of pH and Chloride Concentration on Behavior of Heavy Metal Pollutants: Mercury (II), Cadmium (II), Zinc (II), and Lead (II), "Journal of Enviconmental Quality, 2:444-451 (1973).

Hargis, J.R., "Ventilation and Metabolic Rate of Young Rainbow

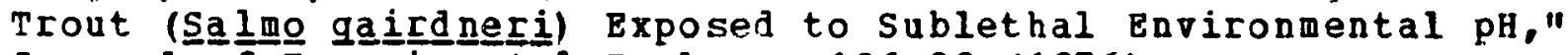
Journal of Experimental Zoology, 196:39 (1976).

Hargreares, J.H. and B.A. Whitton, "Effect of pH on Tolerance of

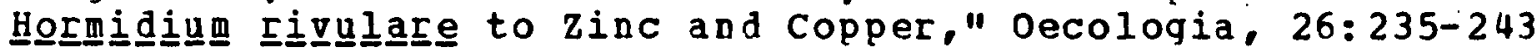
$(1976)$.

Hill, D.M., "Stream Paunal Recovery After Manganese Strip Mine Reclamation," Ph.D. thesis, University of Michigan, Ann Arbor (1972). 
Huckabee, J.H., C.P. Goodyear, and R.D. Jones, "Acid Rock in the Great Smokies: Unanticipated Impact on Aquatic Biota of Road Construction in Regions of Sulfide Mineralization," Transactions of the American Fisheries Society. 104 (4):677-684 (1975).

Janssen, R.G. and D.J. Randill, "Effects of Changes in pH and C02 in Blood and Water on Breathing in Rainbow Trout, sallmo gair d.

Johansson, N. and J.E. Kihlstrom, "pikes (Esox to be Affected by Low $p H$ Values During First Veeks after Hatching." Environmental Research, 9:12 (1975).

Johansson, N., J.E. Kihlstrom, and A. Nahlberg, "Low pH Values Shown to Affect Developing Bish Eggs (Brachydanio reiㅡ응 Hamilton-Buchanan)."Ambio, 2(1/2):42-43 (1973).

Keeney, D.R., "Fate of Nitrogen in aguatic Bcosystems," Rutrophication Information Program. Iiterature Review No. 3, University of Wisconsin Nater Resource Center, Madison (1972). (NTIS PB-209 217)

Rimmel, W.G. and D.C. Hales, "Acute Toxicity of Low pH to Aquatic Insects," Fish Food organisms in Acid line haters of Pennsylvania, U.S. Environmental Protection Agency Report EPA-R3-73-032, pp. 125-158 (19.73).

Koellinq. J.J.." "Pelationship of Trace Elements to Alqae Growth," Ph.D. thesis, Washington State University, Pullman (1971).

Krishna, D.. "Effect of Changing pH on Developing Trout Eggs and Larvae," Nature, 17:434 (1953).

Lansing, A.I. "Some effects of Hydrogen Ion Concentration, Total Salt Concentration, Calcium and citrate on Longevity and Fecundity of the Fotifer," Journal of Bxperimental zoology, 92:195-212 (1942).

Leivestad, H. and I.P. Muniz, "Fish Kill at Low pH in a Norwegian River," Nature, 259:391 (1976).

Lloyd, R. "Rater Quality Criteria for European Freshwater Pish. Report on Extreme pH Values and Inland Fisheries," Buropean Inland Pisheries Advisory Commission Technical Paper No. 4 $(1968)$.

McKin, J.M.. et al.. "Effects of Pollution on Freshwater Bish," Journal of the water pollution control pederation. $45(6)$ : 1370-1407 (June 1973).

Mahdi. M.. "studies of Factors Affectina Survival of Nile Fish in the Sudan. I. The Effect of Hydrogen Ion Concentration," Marine Biology, $18(2): 89-92$ (1973). 
Marking, L.I. and L.E. Olson; "Toxicity of the Lampricide 3-Trifluoromethyl-4-Nitrophenol (TFM) to the Nontarget Fish in Static Tests," Investigations in Fish Control, U.S. Department of the Interior, Fish and Wildife Service, washinaton, D.C. (1975).

Menendez, R.. "Chronic Effects of Reduced pH on Brook Trout

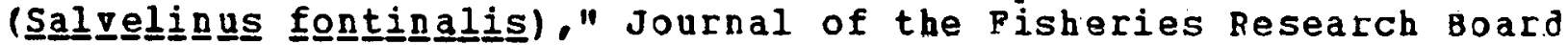
of Canada. $33: 118-123$ (1976).

Merlini, M. and G. Pozzi, "Lead and Freshwater Fishes: Part 1 Lead Accumulation and Water pH," Environmental Pollution, $12: 167-172$ (1977) .

Merlini, M. and G. Pozzi, "Lead and Freshwater Fishes: Part 2 Ionic Lead Accumulation," Environmental pollution, 13:119-126 $(1977)$.

Mierle, G. and P.M. Stokes, "Heary Hetal Tolerance and Metal Accumulation by Planktonic. Algae," Trace substances in Rnvironmental Health - $x$, oniversity of Missouri, Columbia, 113 (1976).

Mount, D.I., "Effect of Total Hardness and pH on Acute Toxicity of Zinc to Fish," International Journal of Air and Water Pollution, 10:49-56 (1966).

Mount, D.I., "Chronic Effect of Low pH on Fathead Minnow Survival, Growth and Reproduction," Hater Research, 7(7):987-993 (1973).

Mudqe, J.E.. "Influence of Low pH on Electrolytes and Interrenal Histochenistry in Brook Trout (Salvelinus fontinalis)." Ph. D. thesis, The Pennsylvania State University, Oniversity Park (1972).

Packer, R.K, and W.A. Dunson, "Effects of Low Environmental pH on Blood pH and Sodium Balance of Brook Trout," Journal of Experimental Zoology, 174:65-72 (1970).

Packer, R.K. and W.A. Dunson, "Anoxia and Sodium Loss Associated with the Death of Brook Trout at I.ow pH," Comparative Biochemistry and Physiology, 41A:17-26 (1972).

Pagenkopf, G.K., R.C. Russo, and R.V. Thurston, "effect of Complexation on Toxicity of Copper to Fishes, "Journal of the Pisheries Research Board of Canada, 31:462-465 (1974).

Porter, K.R. and D.E. Hakanson, "Toxicity of Mine-Drainage to

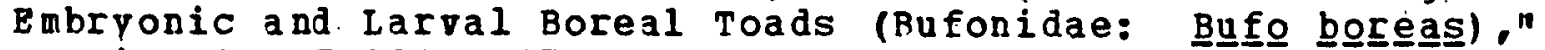
Copeia, 2:327-331 (1976). 
Powers, E.B., "Physiology of the Respiration of Fishes in Relation to the Hydrogen Ion Concentration of the Medium," Journal of General Physiology, 4:305 (1922).

Reihl, M.H., H.H. Weiser, and B.T. Rheims, "Survival of Bacteria in High $\mathrm{pH}$ Maters," Public Health Engineering Abstracts

(Nov./Dec. 1950).

Robinson, G.D., et al., "Differences in Low pH Tolerance among

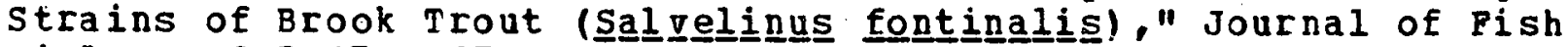
Bioloqy, 8:5-17 (1976).

Sano, H., "The Role of $\mathrm{pH}$ on the Acute Toxicity of sulfite in Water," Water Research, 10:139-142 (1976).

Sheridan, J.R., "Fish Population: Influences of Strip Mining on the Hydrobiologic Environment of Parts of Beaver Creek Basin, Ky.. 1955-1966," 0.5. Geological Survey Professional Paper No. 427-C, pp. C50-C53 (1970).

Singh, S.B., S.C. Banerjee, and P.C. Chakrabarti, "preliminary Observations on Response of Young ones of Chinese Carps to various Physico-Chemical Factors of Water," Proceedings of the National academy of sciences, India, 37 (111):320-324 (1967).

Sparks, R.E., J. Cairns, Jr., and F.B. Cross, "Some Effects of a Neutral Mixture of Calcium oxide and Sulfuric Acid on Channel

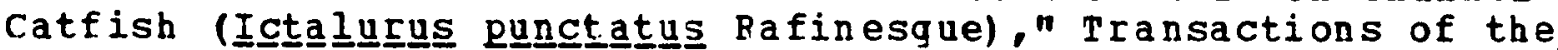
Kansas Academp of science, $72(1): 1-15$ (1969).

Stiemke, R.E. and W.W. Eckenfelder, "Practical Method for Predicting the Fffect of Common Acids and Alkalies on the survival of Fish," Abstracts of the Sewage Works Journal, 20:592 $(1948)$.

Tomiyama, T. and A. Yamagawa, "Effect of pH Upon Toxic Effects of Sulfide and of sulfate to Yound Carp," Nater Pollution abstracts, $26(5): 140(1953)$.

Trama, F.B., "PH Tolerance of the Common Blueqill (Lẹpomis

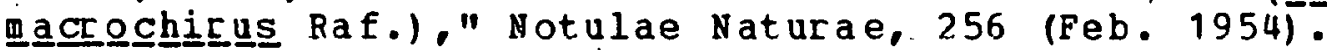

Trojnar, J.R., "Egg and Larval Survival of White Suckers

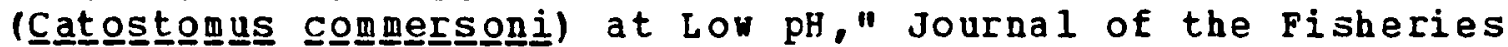
Research Board of Canada, 34 (2):262-266 (1977).

Trofnar, J.R.. "Egg Hatchability and Tolerance of Brook Trout

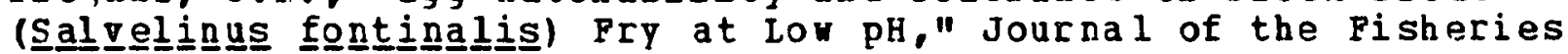
Research Board of Canada, 34 (4):574-579 (1977).

Trussel, R.P.. "The Percent Un-Ionized Ammonia in Aqueous Amonia Solutions at Different pH Levels and Temperatures," Journal of the Fisheries Research Board of Canada, 29(10):1505-1507 (1972). 
Tsai, S.-C.. et al.. "Importance of Water pH in accumulation of Inorganic Mercury in Fish," Bulletin of Environmental

Contamination and Toxicology, 13(2):188-193 (1975).

Vivier, P., "Influence of $\mathrm{pH}$ of Haste Hater on the "Fish Fauna," fair, 41:101 (1954).

Water Pollution Pesearch Laboratory. Stevenage, England, "Fish and vater Quality Criteria," Notes on Hater Pollution, No. 65 (June 1974).

日ells, M. M." "Reactions and Resistance of Fishes in the Natural Environment to Acidity, Alkalinity, and Neutrality," Biological Bulletin, 29:221-257 (1915).

Went, A.E.J. and W.E.'Frost, "River Iiffey Survey V. Growth of Brown Trout (Salmo trutta L.) in Alkaline and Acid Naters," Proceedings of the Bopal Irish Acadeny. Vol. 68, Section B, No. 7. $p D .67-84$ (1942).

Whitley, I.S. and R.A. Sikora, "Fffect of Three Common Pollutants on the Respiration Rate of Tubificid Horms," Journal of the rater pollution Control Federation, Part 2, pp. R57-R66 (1970).

Niebe, A.H., "Notes on the Exposure of Several Species of Pond Fishes to sudden Changes in $\mathrm{pH}$," Transactions of the American Microscopical Society, 50:390-393 (1931).

Niebe, A. H.jo "Notes on Exposure of Several Species of Fish to sudden Changes in the Hydrogen-ion concentration of the Nater and to an Atmosphere of Pure oxygen," Transactions of the American Fisheries society, 61:216-224 (1931).

Yasunaga, Y., "The Influence of Some Pollutants on the Survival of Eqgs and Larvae of Two Species of Flatfish, Limanda yokaha haaㅡ and Paralichtys olizaceus," Bulletin of the Tokai Regional Fisheries Research Laboratory (in Japanese), (96):91-112 (1976).

PHENOL

Alekseyer, V.A. and N.Y. Uspenskaya, "Toxicological Characteristics of Acute phenol Intoxication in some Freshwater norms," Gidrobiologicheskii Zhurnal, 10:48 (1974).

Beer. D., "Effect of Phenols on Microorganisms in the River pleisse," Hasserwirtschaft-Wassertechnik, 4:125-131 (1954).

Brandt, H.J., "Losses to Fish Life Due to Phenolic Naste Waters," Wasserwirtschaft-Wassertechnik, 5:290 (1955). 
Brown. V.M.. "The Calculation of the Acute Toxicity of aixtures of Poison to Rainbow Trout," Rater Research, 2(10):723-733 $(1968)$.

Brown, V.M., B.A. Tiller, and.D.H.M. Jordan, "Acute Toxicity to Rainbow Trout of Fluctuating Concentrations and Mixtures of Ammonia; Phenol, and Zinc," Journal of Fish Biology. 1:1-9 (1969).

Brown, V.M. and R.A. Dalton, "The Acute Lethal Toxicity to Rainbow Trout of Mixtures of Copper, Phenol, Zinc and Nickel," Journal of Pisheries Biology, 2:211-216 (1970).

Brown, V.H.. D.H.M. Jordan, and B.A. Tiller, "gffect of Temperature on the Acute Toxicity of Phenol to Rainbow Trout in Hard Water," Water Research, 1:587-594 (1967).

Brown, V.M.. D.G. Shurben, and J.K. Favell, "Acute Toxicity of Phenol to Rainbow Trout in saline waters," "ater Research. $1: 683-685(1967)$.

Bucke, D. "Neoplasia in Roach (Rutilus rutuiuuㅗ L.) from a Polluted Environment," Progress in Experimental Tumor Research, $20: 205(1976)$.

Buikena, A.L.. Jr., D.R. Lee, and J. Cairns, Jr., "A Screening Bioassay Using Dạhnia pulex for Refinery Wastes Discharged into Freshwater," Journal of Testing and Evaluation, 4(2):119-125 (1976).

Bulicek, J., "Phenol Waste in Waters," Pavlivo, 30:308 (1950).

Cole, A. R.. "Effects of Pollutional wastes on Fish life," symposium on Hydrobiology. Oniversity of Risconsin, Madison, $p$. $241(1941)$.

Cole, S.L. and J. Wilhm. "Effect of Phenol on oxygen Jptake Rate of Laboratory Population of Chírongomus atțenua Research, $7(11): 1691-1700$ (1973).

De I.G. Solbe, J.F.. "Relation Between water Quality and tho status of Fish Populations in willow Brook," tater Treatment and Examination, $22(1): 41-61$ (1973).

European Inland Fisheries Advisory Commission, "nater Quality Criteria for European Freshvater Fish. Report on Monohydric Phenols and Inland Fisheries," EIFAC Technical Paper No. 15 (1972): Water Research, 7:929-941 (1973) .

Foge1s, A and J.B. Sprague, "Comparative Short-Term Tolerance of Zehrafish, Flagfish, and Rainbow. Trout to Eive Poisons Including potential Reference Toxicants." Nater Research, 11:811. (1977). 
Premling, C.R., "Acute Toxicity of the Lampricide 3-Trifluoromethyl-4-Nitrophenol (TFH) to Nymphs of Mayflies (Hexagenia sp.)." Investigations in Fish Control, J.S. Departinent of the Interior, Pish and Wildife Service, Washington, D.C. (1975).

Gersdorff, W.A. and L.E. Smith, "Effect of Introduction of the Halogens into the Phenol Molecule on Toxicity to Goldfish. I. Monochlorophenols," American Journal of Pharmacology, 112:197-204 $(1940)$.

Glickman, A.H., et al.. "Studies of Dptake, Metabolisa, and Disposition of pentachiorophenol and pentachloroanisole in Rainbow Trout," Toxicology and Applied Pharmacology, 41:649 (1977).

Goncharov, G.D. and V.R. Mikryakov, "Effect of Low Concentrations of Phenol on Antihody Pormation in Carp, Cyprinus cángio L. ." Bureau of Commercial Fisheries, (June 1971). (NTIS PB-203 804T)

Guerra, M. and N. Comodo, "Evaluation of Tolerance limits of Some Toxic Substances in Industrial waste waters by the Icthyo-Toxicity Test," Bolletino della Societa Italiano di Biologia Sperimental, $48(22): 989$ (1972).

Hasler, A. and Misby. "Ose of Fish for the olfactory assay of Pollutants (Phenols) in rater," Transactions of the American Fisheries society. 79:64-70 (1949).

Havelka, J. and M. Effenberger, "Symptoms in Phenol Poisoning of Fish," Sport Fishing Abstracts, 2:196 (1957).

Herbert, D.M.M. and J.M. Vandyke. "The Toxicity to Fish of Mixtures of poisons II. Copper-Ammonia and $\mathrm{Z}$ inc-phenol Mixtures," Annals of Applied Biology, 53:415-421 (1964).

Jones, J.R.E., "Peactions of the Minnow (Phoxxingus phoxingus L.) to Solutions of Phenol, Ortho-cresol, and para-cresol," Journal of Experimental Biology, 28:261-270 (1951).

Kawatski, J.A. and M.A. Bittner, "Optake, Blimination and Biotransformation of the Lanpricide

3-Trifluoronethyl-4-Nitrophenol (TFM) by Larvae of the Aquatic

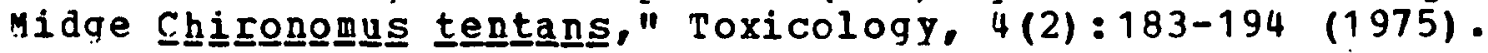

Kobayashi, R.. et al., "studies on the Metabolism of Chlorophenols in Fish 6. Turnover of absorbed Phenol in Goldfish," Bulletin of the Japanese Society of Science and Fisheries, $42: 45$ (1976).

Kopperman, J.L., et al., "Aqueous Chlorination and Ozonation Studies I. Structure-Toxicity Correlations of Phenolic Compounds to Dạ phㅡㅡㄹㅡ maggna.," Chenico-Biological Interactions, $9(4): 245$ (1974). 
Kostyaer. V. Ya.. "Effect of Phenol on the Hydrochemical Regime, Phytoplankton, and plant overgrowth in Artificial Bodies of water," Trudy Instituta Biologii vodokhranilishch, Akademiya nauk SSSR, 24:119-151 (1973).

Krombach, K. and J. Barthel, "Investiqation of a Small Watercourse Accidently polluted by phenol Compounds," Advances in Water Pollution Besearch, Proceedings of tho First International Conference, London, 1962, Vol. 1, pp. 191-203 (1964).

Krist offerson, R., S. Broberg, and A. Oikari, "Physiological Effects of a Sublethal concentration of Phenol in the pike (Esox lucius L.) in Pure Nater;" Annales zoologici, Pennici, 10:392- 397 $(1973)$.

Lamering, M.W. and N.C. Burbank, "Toxicity of Phenol, o-chlorophenol and o-nitrophenol to Bluegill Sunfish," proceedings of the Industrial paste Conference of purdue Oniversity (English Extension Series), 15(106):541-555 (1968).

Maloseja, Z.. Z. Parletic, and I. Munjko, "Biological Decomposition of Phenol by Mixed and Pure Cultures of Algae," Acta Botanica Croatica, 31:129-138 (1972).

Marinescu, A.G., et al.. "The Influence of an Organic Pollutant (Phenol) on the survival and Respiratory Metabolism of Tro

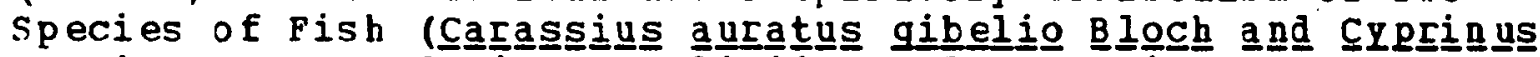
cancpion L.)," Academia Repubici populare Romine, Bucharest, studi si Cercetari de Biologie, seria Biologie mimala, $28(2): 109-115(1976)$; Aquatic Sciences and Fisheries Abstracts. $7(5): 705572(1977)$.

Marking, L.I. and L.E. Olson, "Toxicity of the Lampricide 3-Trifluoromethy1-4-Nitrophenol (TFM) to the Nontarget Fish in static Tests," Investigations in Fish Control, 0.S. Department of the Interior, Fish and rildife service, lashington, D.C. (1975).

Matef. V.E.. "Effects of Phenol on the Central Nervous and Neuroendocrine Systems of Teleosts," In: Antbropogenic Factors and Aquatic Life, N.V. Butorin and M. M. Kamshilov, (eds.). 97 Nauka Publishers, Leningrad, oSSR (1975): Aquatic sciences and Fisheries abstracts, 6,6011796 (1976).

Miller, D.L. and D.M. Ogilvie, "Temperature Selection in Brook Trout (Salvelínus fontinalis) Following Exposure to DDT, PCB, or Phenol," Bulletin of Environmental Contamination and Toxicology. $14(5): 545-551(1975)$.

Mitrovic, v.v., et al.. "Some Pathological effects of sub-acute and Acute Poisoning of Rainbow Trout by Phenol in Hard Nater," water Research, 2:249-254 (1968). 


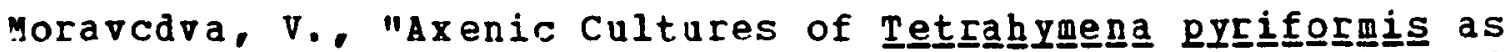
Toxicological Tools," Acta Hydrochimica et Hydrobiologica, 1(4):2 (1976).

Reynolds, J.H., et al. "Effects of Temperature on oil Refinery Waste Toxicity." Journal of the Water Pollution control Federation, $47(11): 2674-2693$ (1975).

Ruthren, J.A. and J. Cairns, Jr., "Response of Fresh-Water Protozoan Artificial Commuities to Metals," Journal of Protozoology, 20(1):127-135 (1973).

Skrapek, K., "Toxicity of Phenols and Their Detection in Fish," Public Health Engineering Abstract, 44:272 (1964).

Sollmann, T." "Correlation of the Aquarium Goldfish Toxicities of Some Phenols, Quinnones, and other Benzene Derivatives with Their Inhibition of. Auto-oxidative Reactions," Journal of General

Physiology. 32:671-679 (1949).

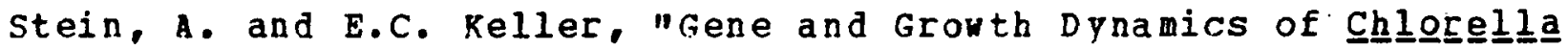
nnder Continuous culture During Phenol Stress," Proceedings of the West virainia Academy of Science, $45(2): 103-111$ (1973).

Stom, D.I.. et al.. "Influence of Phenols and Their Oxidation Products on aquatic plants and their content of sulfhydryl Groups," Doklady Biochemistry, 216(1-6):233-236 (1974).

Trama, F.B., "Acute Toxicity of Phenol to the Common Bluegill

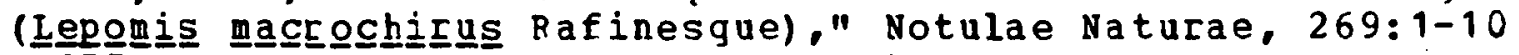
$(1955)$.

Waluqa, D.. "Phenol-Induced Changes in the peripheral Blood of

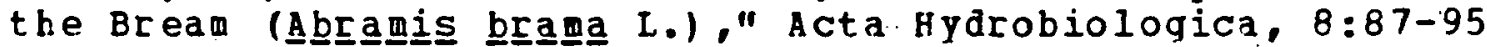
$(1966)$.

Waluga, D.. "Zmiany anatomo-histologiczne u leszcza pod wplywen fenolu. Phenol Effects on the Anatomico-Histophathological Changes in Bream (Ábrangis braama I.)," Acta Hydrobiologica, 8: 55-78 (1966).

Water Pollution Research Laboratory, Stevenage, England, "Fish and Water Quality Criteria," Notes on Nater Pollution, No. 65 (June 1974).

Whit ley, L.S: and R.A. Sikora, "Effect of Three common Pollutants on the Respiration Rate of Tubificid Norms," Journal of the Water Pollution Control Federation, Part 2, Pp. R57-R66 (1970).

Yasunaqa, Y.. "The Influence of Some Pollutants on the Survival of Eggs and Larvae of Two species of Flatfish. Limang

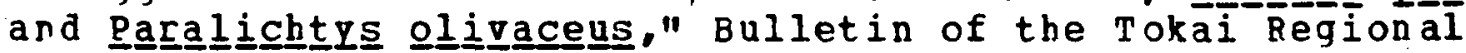
Fisheries Research Laboratory (in Japanese), (86):81-112 (1976). 
POTASS IOM

Bodine, JoH., "Action of Sodium, Potassium, and Calcium Chlorides

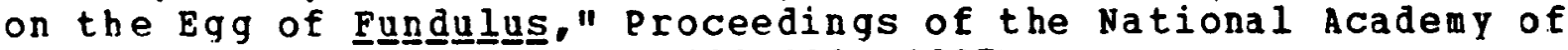
Sciences of the U.S.A.. 13:698-699 (1927).

Bodine, J.H., "Action of Salts on Fundulus Egg I. Action of Na, $K$. and Ca Chlorides Opon the Egg of Fungduluㅗㅇ, "Biological Bulletin, 54:396-404 (1928).

Frahm, J.P., "Toxicity Tolerance studies Dtilizing Periphyton (Toxitoleranzversuche an Hassermoosen)," Gewasser und abwasser, 57/58:59-66 (1975).

Guerra, $M$. and N. Comodo, "Evaluation of Tolerance limits of Some Toxic Substances in Industrial Haste $N$ aters by the

Icthyo-Toxicity Test," Bolletino della Societa Italiano di Biologiz Sperimental, $48(22): 989$ (1972).

Imlav, M.J.. "Effects of Potassium on Survival and Distribution of Freshwater Mussels," Malacoloqia, 12(1):97-113. (1973).

Salzinger, K., et al.. "Bebavior of the Goldfish as an Early warning System for the Presence of Pollutants in Nater," Journal of Environmental systems, 3(1):27-40 (Spring 1973).

Tabata, K.. "Studies on the Toxicity of Heary Metals to Aquatic Animals and the Factors to Decrease the roxicity II. Antaqonistic action of Hardaess components in nater on the Toxicity of Heavy Metal Ions," Bulletin of Tokai Regional Fisheries Research Iaboratory, 58:215-232 (1969).

Trama, F.B.. "Acute Toxicity of Some common salts of Sodiun, Potassium, and Calcium to the Common Bluegill (Leponis ma Sciences of Philadelphia, 106:185-205 (1954).

\section{SEIENI UM}

Adams, W.J., "The Toxicity of Residue Dynamics of Selenium in Fish and Aquatic Invertebrates," Dissertations Abstracts. $37-27,056(1976)$.

Beal, A.P.. "Selenium in Fish Tissue," Journal of the Fisheries Besearch Board of Canada, 32:249 (1975).

Rringmann, G. and R. Kuhn, "The Toxic effects of raste Nater on Aquatic Bacteria, Algae, and Small crustaceans." Gesundheits-Inaenieur, 80:115 (1959). 
Cardwell, R.D., et al.. "acute Toxicity of selenium Dioxide to Freshwater Fishes, "Archives of Environmental Contamination and Toxicology. $4(2): 129-144$ (1976).

Copeland, F., "Selenium: The Unknown Pollutant," Limnos, 3:7-9 (1970).

E11is. M. M., et al.. "Selenium Poisoning in Fishes," Proceedings of the society for Experimental Biology and Medicine. $36: 519-522$ (1937).

Fowler, S.W. and G. Benayoun, "Influence of Environmental Factors on Selenium Flux in Two Marine Invertebrates," Marine Biology. $37: 59-68$ (1976).

Ganther, H.B." "Selenium, the Biological Effects of a Highly Active Trace Substance," Trace substances in Environmental Health, Vol. VI, D.D. Hemphill, (ed.), Oniversity of Missouri, Columbia (1972).

Ganther, H.E., et al.. "Protective Effects of Selenium Against Heav Metal Toxicities," Trace Substances in Bnvironmental

Health, Vol. VI, D.D. Hemphill, (ed.). Oniversity of Missouri, columbia, pp. 247-252 (1972).

Ganther, H.F.. et al.. "Selenium: Relation to Decreased Toxicity of Methylmercury Aded to Diets Containing runa," Science, 175: 1122 (1972).

Great Lakes Laboratory. "Chromiun, Cadmiun, Arsenic, Selenium, Mercury, and aquatic Life: A Brief Iiterature Review," state University College at Buffalo, N.Y.. Special Report No. 9 (1971).

Huckabee; J.W. and N:A. Griffith, "Toxicity of Mercury and Selenium to the Egas of Carp (CYprinns carpio), "Transactions of the American Pisheries Society, $10 \frac{3}{3}(4): 822-825$ (1974).

Hutchinson, T.C., "Comparative studies of the Toxicity of Heavy Metals to Phytoplankton and Their Synergistic Interactions," Water pollution Research in Canada, 8:68-90 (1973).

Kim. J.H.. et al.. "Protective Action of selenium Against Mercury in Northern Creek Chubs," Bulletin of Environmental Contamination and Toxicology, 17: 132 (1977).

Kumar, H.D. and G. Prakash, "Toxicity of selenium to the

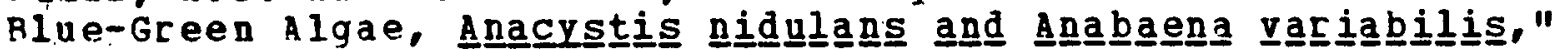
Annals of Botany, $35: 697-705$ (1971).

Lakin. H..." "Selenium in our Environment," Trace Elements in the Environment, O.S. Geological Survey, Denver, Colo. pp. 97-111 (1972). 
Nelson, J.J.." "A Model for the Movement of Selenium in a closed Aquatic System," University of Oklahoma, Norman. (1974).

Niimi, A.J. and O.N. LaHam, "Selenium Toxicity on the Early Stages of Zebrafish (Brachydanio reriol, " Journal of the Fisheries Research Board of Canada, $32(6): 803-806$ (1975).

Niimi, A.J. and Q.N. LaHam, "Relative Toxicity of Organic and Inorqanic Compounds of Selenium to Newly Hatched Zebrafish (Erachydanio re도으)," Canadian Journal of Zoology. 54:501-509 $(1976)$.

Parizek, J.. "Interactions of selenium vith Mercury, Cadmium, ànd other Toxic letals," Proceedings of the symposium on Trace Element Metabolism in Animals, University of Wisconsin, Madison (1973).

Rosenfeld, I, and O.A. Beath, "Selenium Geobotany, Biochemistry; Toxicity, and Nutrition," Azademic Press, New York (1964).

Sakurayama, H., "Studies on Selenium Poisoning 7. Experimental Studies on Rearing of Fishes, Shells and Duckweed in selenicus Acid Solution," Shikoku acta medica, 16:122-127 (1960).

Sandholm, M., H.E. Okanen, and L. Pesonen, "Uptake of selenium by Aquatic Organisms," Limnology and Oceanography, 18(3):496-499 (1973).

Schrift, A.." "Sulfur, Selenium Antagonism 1. Antimetabolite Action of Selenate on the Growth of Chblorsell Journal of Botany. 41:223-230 (1954).

Schwarz, K.. "Effects of Trace Amounts of Selenium," proceedings of the Conference on the Physiological Effects of Water Quality, p. $79(1960)$. "Selenium in Plankton," Marine Pollution Bulletin. $2(5): 69(1971)$.

U.S. Environmental Protection Agency. "preliminary Investigation of Fifects on the Environment of Boron, Indium, Nickel, Selenium, Tin, Vanadium and Their Compounds IV. Selenium," Report BPA $560 / 2-75 / 005 d$ (1975). (NTIS PB-245987/3ST)

wier. P.A. and C.H. Hine, "Effects of Various Metals on Behavior of Conditioned Goldfish," Archives of Environmental Health, $20(1): 45-51(1970)$.

Weswig, P.H., "Seleniun in the Environment," Heary Metals in the Environment, oreqon State University Rater Resources Research Institute Report SEMN WR 016.73. pp. 183-203 (1973) . 


\section{SIIVER}

Amiard, J.C., "Experimental study of Acute Toxicity of salts of Cobalt, Antimony, Strontium and Silver in crustaceans and Their Larvae and in Some Teleosts," Revue Internationale d'Oceanoqraphie Medicale, (in French).43:79-95 (1976); Selected water Resources Abstracts, 10: W77-07728 (1977).

Bard, C.C., et al., "Silver in Photoprocessing Effluents," Journal of the Hater pollution Control Pederation, $48(2): 389-394$ $(1976)$.

Bryan, G.W., "Some Aspects of Heavy Metal Tolerance in Aquatic Organisms," A.P.M. Lockrood, (ed.), Cambridge Oniversity Press, N. Y. 35 pp. (1977).

Buikema, A.L., Jr., J. Cairns, Jr., and G.W. Sullivan, "Evaluation of Philodina acuticornis (Rotifera) as a Bioassay Organism for Heavy Metals," Water Resources Bulletin, $10(4): 648-661$ (1974).

Calabrese, A., et al.. "Toxicity of Heavy Metals to Embryos of

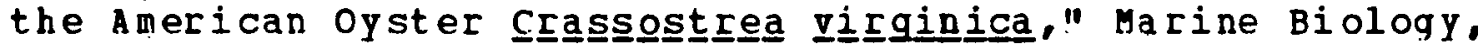
18:162-166 (1973) .

Calabrese, A.. et al., "Effects of Cadmium, Mercury and Silver on Marine Animals," Marine Fisheries Review, 39:5 (1977).

Calabrese, A.. et al.. "Survival and Growth of Bivalve Larvae under Heavy-Metal Stress," Marine Biology, 41:179-184 (1977).

Cearley, J.F., "Toxicity and Bioconcentrations of Cadmium,

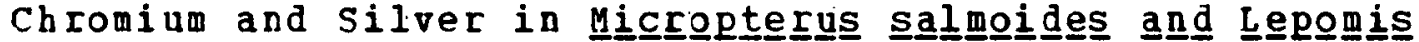
macrochhisus," Ph.D. thesis, University of Oklahoma, Norman, 76 pp. (1971).

Christensen, G.M., "Eefects of Metal Cations and Other Chemicals Opon the in vitro Activity of Two Enzymes in the Blood plasma of the white Sucker, Catostostormera commersoni (L acepede) " Chemical-Biological Interactions, 4:351-361 (1971).

Coleman, R.I. and.J.E. Cearley, "Silver Toxicity and Accumulation in Largemouth Bass and Bluegill," Bulletin of Environmental Contamination and Toxicology, 12(1):55-61 (1974).

Cowe11, B.C., "Effects of sodium Arsenite and silvex on the Plankton Populations in Farn Ponds," Transactions of the American Pisheries Society, 94 (4):371-377 (1965).

Doudoroff, P., G. Luduc, and C.R. Schneider, "Acute Toxicity to Fish of Solutions Containing Complex Metal cyanides, in Relation to Concentrations of Molecular Hydrocyanic Acid," r.ransactions of the american Fisheries Society, 95(1):6-22 (1966). 
Gardner, G.R., "Chemically Induced Lesions in Estuarine or Marine Teleosts," Pathology of Fishes, W. E. Ribelin and G. Migaki. (eds.), University of Hisconsin Press, Madison, pp. 657-693 $(1975)$.

Hale, J.G., "Toxicity of Metal Mining Wastes," Bulletin of Environmental Contamination and Toxicology, 17:66 (1977).

Hannan, P.J. and C. Patouillet, "Effect of Mercury on algal Growth Rates," Biotechnology and Bioengineering, 14:93-101 (1972).

Hutchinson, T.C., "Comparative studies of the Toxicity of Heary vetals to phytoplankton and Their synergistic Interactions," water Pollution Re search in Canada, 8:68-90 (1973).

Hutchinson, T.C. and H. Czyrska, "Heavy Metal Toxicity and Synergism to Floating Aquatic Weeds," Verhandlungen Internationale Vereiniguna fur Theoretische und Angewunde Limnologie, 19:2102-2111 (1975).

Jackim, E.. "Influence of Lead and other Metals on Pish Delta-Aminolevulinate Dehydrase Activity, "Journal of the Fisheries Research Board of Canada, 30 (4):560-562 (1973).

Nelson, D.A., et al.. "Bioloqical Effects of Heary Metals on Juvenile Bay Scallops, Argopecten irradians, in Short-Term Exposures," Bulletin of Environmental Contamination and Toxicology, $16: 3$ (1976).

Poon, C.P.C. and K.H. Bhayahi, "Metal Toxicity to serage Organisas," Proceedings of the American Society of Civil Engineers, Journal of the Sanitary Engineering Division, Vol. 97 $(19.70)$.

Thurberg, F.P. and R.S. Collier, "Bespiratory Response of Cunners to Silver," Marine pollution Bulletin, 8(2):40 (1977).

Thurberg, F.P., A. Calabrese, and H.A. Dawson, "Effects of silver on Oxygen Consumption of Bivalves at various Salinities," In: Pollution and Physiology of Organisms, F.J. Vernberg and W.B. vernberq, (eds.), Academic Press, New York, pp. 67-78 (1974).

Whitton. B.A., "Toxicity of Heavy Metals to Freshrater algae: A Beview," Phykos, $9(2): 116-125$ (1970).

Young, R.G. and D.J. Lisk, "Effect of Copper and Silver Ions on Algae," Journal of the Water Pollution Control Federation, $44(8): 1643-1647$ (1972). 


\section{SODIIIM}

Anderson, B.G., "Toxicity Thresholds of Various sodiun Salts

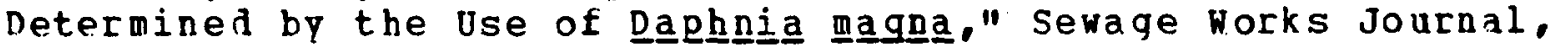
$18: 82(1946)$.

Bodine, J.H., "Action of Sodium, Potassium, and Calcium Chlorides on the Egg of Fundulu Sciences of the 0.S.A., 13:698-699 (1927).

Bodine, J.H., "Action of Salts on Fundulus Egg I. Action of $N$, $K$, and Ca Chlorides upon the Egg of Funduuㅡㄴ. Bulletin, 54:396-404 (1928).

Costa, H.H., "Responses of Preshwater Animals to Sodium Cyanide Solutions," Ceylon Journal of Sciences, Biological Sciences, 5:41 $(1965)$.

Promm, P.o., "Toxic Action of water soluble pollutants on Freshwater Fish," EPA Water Pollution Control Research Series No. 18050DST, U.S. Government Printing office, Washington, D.C. (1970); Michigan State Oniversity Nater Pollution Control Research Series, East Lansing (1970). (NTIS PB-201 650)

Jones, J.R.E., "A Study of the Relative Toxicity of Anions with

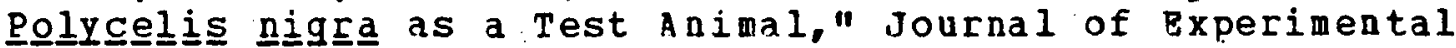
Bioloqv. 18:170-181 (1941).

Nishikawa, $K$. and $K$. Tabata, "Studies on the Toxicity of Heavy Metals to Aquatic Animals and the Factors to Decrease the Toxicity III. On the Low Toxicity of some Heary Metal complexes to Aquatic Animals," Bulletin of Tokai Reaional Fisheries Research Laboratory, 58:233-241 (1969).

Scheuring, L.. "Experiments on the Action of Na2so4 on Fish and other Water Organisms," Bioloqical Abstracts, 25:26463 (1951); nater Pollution Abstracts, $27(8): 191$ (1952).

Trama, F.B., "Acute Toxicity of some common salts of sodium, Potassium, and Calcium to the Common Blueqill (Lepomis

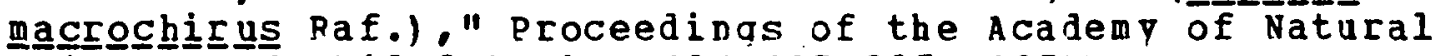
Sciences of Philadelphia, 106:185-205 (1954).

\section{STRONTIUM}

Amiard, J.C., "Fxperimental study of Acute Toxicity of salts of Cobalt. Antimony. Strontium and Silver in Crustaceans and Their Larvae and in Some Teleosts," Revue Internationale d'Oceanographie Vedicale, (in French). 43:79-95 (1976); Selected water Resources Abstracts, 10:w77-07728 (1977). 
Harver, R.S. and R. Patrick, "Concentration of $137 \mathrm{Cs}, 65 \mathrm{zn}$, and $855 r$ by Fresh water Algae," Biotechnoloqy and Bioengineering; $9: 449-456(1967)$.

Loev, 0.. "Concerning the Effect of Strontium Salts on Algae," Flora, 2:96 (1911).

Owens, M.. et al.. "Uptake and Release of Radioactive strontium by Freshwater Plants," Proceedings of the society for Nater Treatment and Examination, 10:53 (1961).

Bice, T.R., "The Accumulation and Exchange of Strontium by Marine Planktonic Algae," Limnology and Oceanography, 1:123 (1956).

Salzinger, R.. et al., "Behavior of the Goldfish as an Early warning system for the Presence of Pollutants in Water," Jouraal of Environmental Systems, 3(1):27-40 (Spring 1973).

Saurov, M. "Fadioactive Contamination of Fish in Mater Containing strontium," Nater Pollution Abstracts, 32:3,107 (1959).

Spooner, G.M.. "Observations of the Absorption of Radioactive Strontium and Yttrium by Marine Algae," Journal of the larine Biological Association of the united Kinqdom, 28:587-726 (1949).

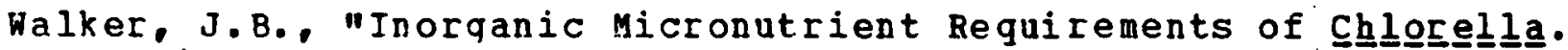
I. Requirements for Calcium (or Strontium), Copper, and Molybdenum," Archives of Biochemistry and Biophysics, 46:1-11 $(1953)$.

Walker, J.B.. "Strontium Inhibition of Calcium otilization by a Green Alga," Archives of Biochemistry and Biophysics, 60:264-265 $(1956)$.

Yoshii, G..N. Natabe, and Y. Ohada. "studies on the Optake of P32, S35, Ca45, Sr89 in the Tissues of Fish," Bulletin of the Japanese Society of Science and Pisheries, 22:240 (1955).

\section{SULFATE}

Becker. A.J.. Jr. and E.C. Keller, Jr.. "Effects of Iron and Sulfate compounds in the Growth of Chlorella," Proceedings of the West Virginia Academy of Science, 45:127 (1973).

Huckabee, J.W...C.R. Goodyear, and R.D. Jones, "Acid Rock in the Great smokies: Inanticipated Impact on Aquatic Biota of Road Construction in Regions of Sulfide Mineralization," Transactions of the American Fisheries Society, 4:677-684 (1975). 
Macfadyen, W. A.. "Sulfates in African Inland Waters," Nature, $171: 769$ (1953).

Macfadyen. N.A.. "Sulfates in African Inland Naters," Letter to the Editor, Nature, $172: 595$ (1953).

Scheuring, L.. "Experiments on the Action of $\mathrm{Na} 2 \mathrm{SO} 4$ on Fish and Other Water Organisms," Biological Abstracts, 25:26463 (1951); Water Pollution Abstracts, 27 (8): 191 (1952).

Yasunaqa, Y., "The Influence of Some pollutants on the Survival of Eggs and Larvae of Two Species of Flatfish, Li and Paaㅣ도드ys olivaceus," Bulletin of the Tokai Reqional Fisheries Research Laboratory (in Japanese), (86):81-112 (1976).

\section{SULFIDE}

Adelman, I.R. and L.L. Smith, "Effects of Hydrogen sulfide on Northern Pike Eqgs and Sac Pry," Transactions of the american Fisheries Society, 99:501-5)9 (1970).

Adelman, I.R. and L.L. Smith, Jr.. "Toxicity of Hydrogen Sulfide

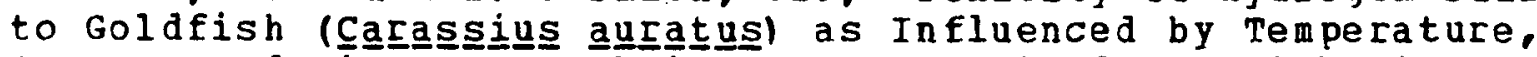
oxyqen, and Bioassay Techniques," Journal of the Fisheries Pesearch Board of Canada, 29:1309-1317 (1972).

Bella, D.A.." "Benthal sulfide Release in Aquatic systems," Oregón Water Resources Research Institute, Corvaliis (1974). (NTIS $P B-2370741$

Bonn, E.H. and B.J. Follis, "Effects of Hydrogen sulfide on Channel Catfish (I ctalurus punctatuss)." Transactions of the American Fisheries Society. 96(1):39-36 (1967).

Broderius, S.J. and L.I. Smith, Jr.. "Effect of Hydrogen Sulfide on Fish and Invertebrates II. Hydrogen Sulfide Determination and Relationship Between $p H$ and Sulfide Toxicity," U.S. Environmental Protection Aqe nCY Report ERA-600/9-76/062b (1976).

Brown, A.C.. "Effect of Hydrogen Sulphide on Bullia (Gastropoda)." Nature, 203 (4941):205-206. (1964).

Chen, K.Y. and J.C. Morris, "Kinetics of Oxidation of Aqueous sulfide by 02 " Environmental Science and Technoloqy. $6(6): 529-537$ (1972).

Christensen, G.M., "Effects of Metal Cations and other chemicals Jpon the in vitrro Activity of $T$ wo Enzymes in the Blood plasma of the white Sucker, Catostormera commersoni (Lacepede) " Chemical-Biological Interactions, 4:351-361 (1971). 
Gillespie, D.C. and D.P. Scott, "Mobilization of Mercuric Sulfide from Sedimert into Fish onder Aerobic Conditions," Journal of the Fisheries Research Board of Canada, 28(11):1807-1808 (1971).

Huckabee, J.W., C.R. Goodyear, and R.D. Jones, "Acid Rock in the Great Smokies: Onanticipated Impact on Aquatic Biota of Road Construction in Regions of Sulfide Mineralization," Transactions of the American Fisheries Society, 4:677-684 (1975).

Kurihara, T., et al., "studies on the Tolerance of the Guppy.

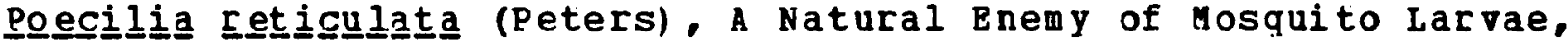
to the Septic Pollution of Hater," Japanese Journal of Sanitation and Zoology, 2,4 (2):165-174 (1973).

Oseid, D.M. and L.L. Suith, Jr.. "Chronic Toxicity of Hydrogen Sulfide to Gammar Fisheries society. $103(4): 819-822$ (1974).

Oseid, D.M. and L.L. Smith, Jr., "Pactors Influencing acute Toxicity Estimates of Hydrogen Sulfide to Preshwater

Invertebrates," Hater Research, 8:739 (1974).

Oseid, D.M. and L.L. Smith, Jr., "Long-term Effects of Hydrogen Sulfide on Hexaganenia limbata (Ephemeroptera), " Environmental Entomology, $4(1): 15-18(1975)$.

Sinqh, S.B.. S.C. Banerjee, and P.C. Chakrabarti, "Preliminary orservations on Response of Young ones of Chinese Carps to Various Physico-Chemical Factors of Nater," Proceedings of the National Academy of Sciences, India, 37 (111):320-324 (1967).

Skidmore, ".J.. "An Investigation of Carbon Dioxide, Ammonia, and Hydrogen sulfide as Factors Contributing to Fish Kills in Ice covered Lakes," Progressive Pish-Culturist, 19:124-127 (1957).

Smith, L.L. and D.M. Oseid, "Effects of Hydrogen Sulfide on Pish Eggs and Fry," Nater Research, 6(6):711-720 (1972).

Smith, L.I... Jr. and D.M. Oseid, "Effect of Hydrogen Sulfide on the Development of Eight Freshwater Fish species," proceedings of the International symposium on Early Life History of Fish, oban, Scot l and (1973).

Smith, L.L., Jr, and D.M. Oseid, "Chronic Effects of Low Levels of Hydrogen Sulfide on Freshwater Pish," Hater Pollution Research Proceedings,. S.H. Jenkins, (ed.). Pergamon, New York, Pp. 599-605 (1975): Progress in Water Technology, $7(3 / 4): 599-605$ (1975).

Smith, l. L., Jr., et al.. "Toxicity of Hydrogen sulfide to

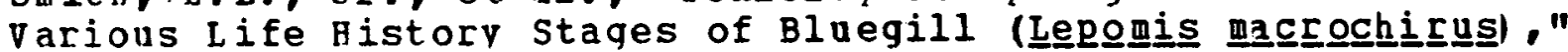
Transactions of the American Fisheries society. 105:442 (1976). 
Smith, L.L...JI.. et al., "scute and Chronic Toxicity of Hydrogen sulfide to the Fathead uinnow, pi

Fnviconmental science and Technology. 10:565 (1976).

ziehell, C.D., et al.. "Field Toxicity studies and Juvenile Salmon Distribution in Port Angeles Harbor, Washington," Journal of the water Pollution Control Federation, 42 (2):229-236 (1970).

SULFOF

Dahl, J., "Transformation of Iron and sulfur compounds in soil. and Its Relation to Danish Inland Fisheries, "Transactions of the American Fisheries Societ $7,92: 260-264$ (1963).

Harkawa, C.. "Preliminary Report on the Toxicity of colloidal Sulfur to Fish," Transactions of the American Fisheries Society. $52: 219(1922)$.

Schrift, A.." "Sulfur, Selenium Antagonism 1. Antimetabolite

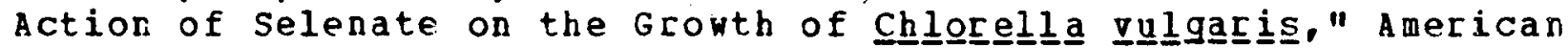
Journal of Botany, 41:223-230 (1954).

Yoshii, G.. N. Watabe, and Y. Ohada, "Studies on the Uptake of P32, S35, Ca45, Sr89 in the Tissues of Fish," Bulletin of the Japanese society of Science and Fisheries, 22:240 (1955).

\section{SUSPENDED SOLIDS}

Bothner, M.H. and R. Carpenter, "Sorption-Desorption Reactions of Mercury with Suspended Matter in the columbia River," presented at the International Atomic Eneray Agency Symposium on the Interaction of Padioactive contaminants with the Constituents of the Marine Environment, Seattle, (July 10-14, 1972).

Brown, V.M.." "Aspects of Heavy Metals Toxicity in Fresh Waters," Proceedings of the International Joint Commission's Workshop on Toxicity to Biota of Metal Forms in Natural Water, October 7-8, 1975. Duluth, Minn.. pp. 59-75 (April 1976).

Buck, H.D.. "Effects of Turbidity on Fish and Fishing," Transactions of the North American wildife Conference, $21: 240-261(1956)$.

Cairns, J.. Jr.. "Suspended solid Standards for the Rrotection of Aquatic Organisms," Proceedings of the 22 nd Industrial waste Conference, Purdue Enqineering Bulletin, 129(1):116-127 (1968). 
Campbell, H.J., "Effect of siltation from Gold Dredging on the Survival of Rainbow Trout and Byed Eggs in Powder River, Oregon," oreqon state Game Commission. 3 pp. (1954).

Cordone, A.J. and D.W. Kelley, "The Influences of Inorganic Sediment on the Aguatic Iife of Streams," California Pish and Game, $47(2): 189-228$ (1961).

Cumming. K.B. and D.H. Hill, "Stream Faunal Recovery After Manqanese Strip Mining Reclamation," U.S. Environmental Protection Agency, Water Pollution Control Research Series No. 18050-D014 (June 1971).

Curt1s, H.R.., "Strip-Mining, Erosion and sedimentation," Transactions of the American society of Agricultural Engineers, $14(3): 434-436$ (1971).

Davis, H.C.. "Effects of Turbidity Producing Materials in.

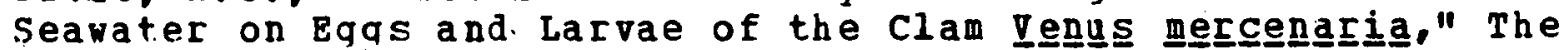
Biological Bulletin, 118:1 (1960).

Doudoroff, P.. "Water Quality Requirements of Pishes and Effects of Toxic Substances," The Physiology of Pishes, Vol. 2, H.E. Brown, (ed.). Academic Press, New York, pp. 403-4.30 (1957).

Ellis, M.M., "Erosion silt as a Factor in Aquatic Environments," Ecology $17(1): 29-42$ (1936).

European Inland Fisheries Advisory Comission, "Water Quality Criteria for European Freshwater Fish, Report on Finely Divided solids and Inland Fisheries," International Journal of Air and water Pollution, 9:151-168 (1965).

Gammon, J.R.. "Effect of Inorqanic Sediment on Stream Biota," O.S. Environmental Protection Agency. Water poliution Control Series Peport EPA-18050-DWC-12/70 (1970).

Greenfield, J.P. and M.P. Ireland, "A Survey of the Hacrofauna of a Coal-Waste Polluted Lancashire Fluvial system," Environmental pollution, 16:105 (1978).

Griffin, I.E. "Experiments on the Tolerance of Young Trout and Salmon for suspended Sediment in water," In: placer Mining on the Rogue River, oreqon, in its Relation to the Fish and Fishing in that stream. by Henry Baldwin Ward, oregon Department of Geology and Mineral Industries, Bulletin 10, Appendix B, Pp. 28-31 $(1938)$.

Hahn, H.H. and R. Klute, "Pollutional Effects of Suspended, Sedimented, and Eroded Particulate Material in the Aqueous Environment," International conference on Environmental sensing and Assessment, Vol. 1, Las Vegas, Ner. (Sept. 14-19, 1975). 
Hellman, H., "Adsorption of Heavy Hetals by suspended Solids in Rhine River. Examination Pertaining to Rhine rater Contamination," Deutsche Gewasserkundliche Mitteilungen, 14:42 $(1970)$.

Herbert, D.W.M. and J.C. Merkens, "Effect of Suspended Mineral Solids on the Survival of Trout," International Journal of Air and water pollution, 5:46-55 (1961).

Herbert, D.W.M. and J.M. Richards, "Growth and Survival of Fish in Some Suspensions of Solids of Industrial origin,"

International Journal of Air and water Pollution, 7:297-302 $(1963)$.

Hoehn, R.C. and D.R. Sizemore, "Acid Mine Drainage (AMD) and Its Impact on a Small virqinia Stream," Water Resources Bulletin, $13(1): 153-160$ (1977)

Kellev. D.W., "Fffects of Siltation on Production of Fish Food Organisms," Proceedings of the 5th symposium of the Pacific Northwest on Siltation--Its Sources and Effects on the Aquatic Environment, Portland, Ore. (March 23-24, 1959).

Lackey, J.B.: G.B. Morqan, and O.H. Hart, "rurbibity Effects in Natural vaters in Relation to nrqanisms and the nptake of Radioisotopes," University of Florida Engineering and Industrial Experimental Station, College of Engineering, Vol. 13, No. 8, Technical Paper 167. 9 pp. (1959).

I.anqlois, T.H.. "Two processes operating for the Beduction.in Abundance or Elimination of Fish species from Certain Types of Water Areas," Transactions of the North American Wildife conference, 6:189 (1941).

Lewis, A.G., P.H. Whitfield, and A. Ramnarine, "Some Particulate and Soluble Agents Affecting the Relationship between Metal Toxicity and organism survival in the Calanoid Copepod Euchạaeta Jäpannica․" Marine Biology, 17:215-221 (1972).

Paffenhofer, G.-A.. "The Influence of 'Red Mud' on Mortality and Body Weight of Juvenile Stages of the Marine planktonic Copepod

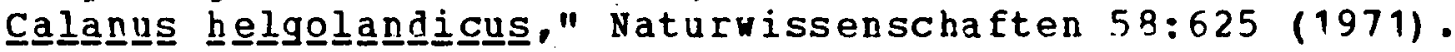

Paffenhofer, G.-A., "The Effects of suspended 'Red Mud' on Mortality. Body Weight, and Growth of the Marine Copepod, Cálangus helgollandicus," Water, Air, and Soil Pollution, 1:314-321 (1972).

Peters, J.C.. "The Effects of Stream sedimentation on Trout Embryo Survival," Biological Problems in Water Pollution, C. M. Tarzwell, (ed.), Washington, D.C., M.S. Public Health Service Publishing No. 999-KP-25, pp. 275-279 (1962). 
Phinney, H.K., "Turbidity, Sedimentation, and Photosynthesis, Siltation - It.s sources and Effects on the Aquatic Environment," 5th Symposium of the Pacific Northwest, 0.s. Public Health Service water Supply and Water Pollution Control Program, Portland, Ore.. pp. 4-12 (1959).

Robertson. M.. "Effects of Suspended Materials on the Reproductive Rate of Daphnia magna," Publications of the Institute of Marine science, University of Texas, 4:265-277 (1957): Sewaqe and Industrial wastes, 31:765 (1959).

Sinah, S.B., S.C. Banerjee, and P.C. Chakrabarti, "Preliminary Observations on Response of Young ones of Chinese Carps to Various Physico-chemical Factors of Hater, "Proceedings of the National Academy of Sciences. India, 37 (111):320-324 (1967).

Smith, E.J., "Bffects of Lime Neutralized Iron Hydroxide Suspensions on Selected species of North American Fish," Ph.D. thesis, Oniversity of Pittsburah, Graduate school of Public Health (1973).

Smith, E.J. and J.L. Sykora, "Early Developmental Effects of Iime-Neutralized Iron Hydroxide Suspensions on Brook Trout and Coho Salmon," Transactions of the American Pisheries society. 105: 308 (1976).

Smith, O.R.." "Placer Mining silt and its Relation to salmon and Trout on the Pacific Coast," Transactions of the American Fisheries society, 69:225-230 (1939).

Sykora, J.L.,.E.J. Smith, and M.A. Shapiro, "Chronic Effect of Perric Hydroxide on Certain species of Aquatic Animals," Proceedings of the 4 th symposiun on Coal Mine Drainage Research, Mellon Institute, Pittsburgh, p. 347 (April 26-27, 1972).

Sykora, J.I., E.J. Smith, and M. Synak, "Effect of Lime Neutralized Iron Hydroxide Suspensions on Juvenile Brook Trout

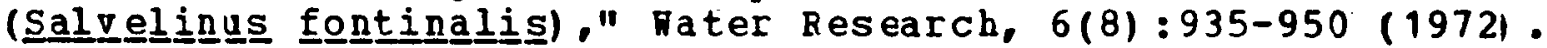

Sykora, J.L., et al., "Some observations on spawning of Brook

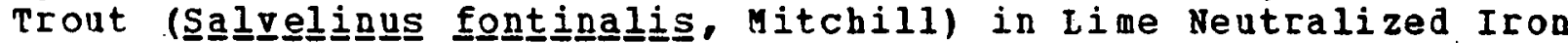
Hydroxide Suspensions," Hater Research, 9(4):451-458 (1975).

Tarao, R., et a 1., "The Accumulation of Mercury in the Fishes Reared in the sea Water Contaminated by suspended solids containing Mercury," (in Japanese with English Summary), Bulletin of the Japanese Society of Scientific Fisheries, 42:1411 (1976).

Tebo, L.B.. Jr., "Effects of Siltation, Resulting from Improper Loggina, on the Rottom fauna of a small Trout stream in. the Southern Appalachians," proqressive Fish-Culturist, 17(2):64-70 (1955). 
Tebo, L.B., Jr., "Effects of siltation on Trout Streams," proceedings of the 1956 Meeting of the society of anerican Foresters, pp. 198-202 (1957).

wallen. I.E., "Direct Effect of Turbidity on Fishes," Bulletin of the Oklahoma Agrjcultural and Mechanical College, Arts and

science studies, Biology series vol. 48, No. 2, 27 p. (1951).

wallen, I.E.. W.C. Greer, and R. Lasater, "Toxicity to Gạmbusía affinis of: Certain Pure Chemicals in Turbid Waters," Sewaqe and Industrial wastes, 29 (66):695-711 (1957).

Water Pollution Research Iaboratory, Stevenage, England, "Fish and Water Quality Criteria," Notes on Water Pollution, No. 65 (June 1974).

Wilson, J.N., "P.fects of Turbidity and Silt on Aquatic Life," seminar on the Biological Problems in Water Pollution. R.A. Taft Sanitary Enqineering Center, Cincinnati, Ohio, pp. 235-239 $(1957)$.

Ziebell, C.D., "Silt and Pollution," Mashington Pollution Control Commission, Information Series No. 57-1, 4 pp. (1957).

\section{THA I.L I UM}

Dilling, W.J. and C.W. Healey, "Influence of lead and the Metallic Ions of Copper, Zinc, Thorium, Beryllium, and Thallium on the Germination of Frogs' Spawn and on the Growth of Tadpoles," Annals of Applied Bioloqy, 13(2):177-188 (1926); Biological Abstracts, 2:3485 (1928).

Downs, W.L.. et al.. "Acute and Sub-Acute Toxicity studies of Thallium Compourds," American Industrial Hygiene association Journal, 21:5,399 (1960).

Mathis, B.J. and N.R. Kevern, "Distribution of Mercury, Cadmium, Lead and Thallium in a Eutrophic Lake," Hydrobiologia. $46(2-3): 207-222(1975)$.

Zitko, V., "Toxicity ard Pollution Potential of Thallium," The Science of the Total Environment, 4:185-192 (1975).

Zitko, $\nabla$. . "Chemistry, Applications, Toxicity and Pollution Potential of Thallium," Fisheries and Marine Service, Environment Canada, Technical Report No. 518 (1975).

Zitko, V., W. v. Carson, and W.G. Carson, "Thallium: Occurrence in the Environment and Toxicity to Fish," Bulletin of Environmental contanination and Toxicology, 13(1):23-30 (1975). 


\section{VAN ADI OM}

Jenkins, D.W.. "Flow of Toxic Metals in the Environment," International conference on Environmental Sensing and Assessaent, vol. I, Las Vegas. Nev. (Sept. 14-19, 1975).

Kalk. M., "Absorption of Vanadium by Tunicates," Nature, 198:1010-1011 (1963).

Kustin, K., K.V. Ladd, and G.C. Mcleod, "Site and Rate of

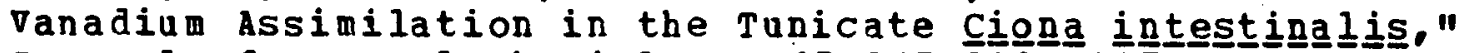
Journal of General Physiology, 65:315-328 (1975).

Meisch, H.J. and H.J. Bieliq, "Effect of Vanadium on Growth, Chlorophyll Formation, and Iron Metabolism in onicellular Green Algae." Archive fuer Mikrobiologie, 105:77 (1975).

Montiel, A.. "Vanadium in Rainwater and Effects on Surface Water." Water Pollution Research Proceedings, S.H. Jenkins, (ed.), Pergamon, New York, pp. 743-751 (1975): Progress in Hater Technoloqy, $7(3 / 4): 743-751$ (1975).

Soremark, R., "Vanadium in Some Biological specimens," The Journal of Nutrition, 92:183-190 (1967).

Tarzwe11, C.M. and C. Henderson, "Toxicity of Some of the Less Common Metals to Fishes," Transactions of the seminar on sanitary Engineering Aspects of the Atomic Energy Industry, Robert A. Taft Engineering Center Report TID-7517 (1956).

0.S. Environmental Protection Agency, "Preliminary Investigation of Effects on the Environment of Boron, Indium, Nickel, Seleniug, Tin, Vanadium and Their Compounds VI. Vanadium," Report No. FPA-560/2-75/005F (Aug. 1975). (NTIS PB-245999/9ST)

\section{ZINC.}

Affleck, A.J.. "zinc Poisoning in a Trout Hatchery," Australian Journal of Marine and Freshwater Research, 2:142-169 (1952).

Ahsanullab, M.. "Acute Toxicity of Cadmium and Zinc to seven Invertebrate species from Hestern Port, Victoria," Australian Journal of Marine and Freshwater Research, 27 (2):187-196 (1976).

Alekseenko, V.A.. et al.. "Migration of Lead and zinc in Surface Waters During the Sharp Enrichment of the Haters with sulfides of the Metals," Izvestiya Akademii Nauk Kazakhskoi SSR, Seriya Geoloqich eskaya (USSR), 30 (2):76 (1973); Chemical abstracts, $79: 209$ (1973). 
Anderson, R.A., et al.. "Survival and Growth of Tangy dissimilas (Chronomidae) Fxposed to Copper, Cadmium, zinc, and Nickel," National Environmental Research Laboratory. Duluth, Minn.. Quarterly Reports (1975).

Anderson, R.V., "Cadmium, Copper, Lead, and zinc: Tracemetal Pollutants in an Aquatic Ecosystem," NSF-SOS Grant GY-10814 Final Report, National science Poundation, Washington, D.C., 275 pp. (1973).

Anderson, P.V.. "The Occurrence of Cadmium, Copper, Lead, and Zinc in uacroinvertebrates of the Fox River, IIIinois," Onpublished M.S. thesis, Department of Biological science, Northern Illinois University; Dekalb, 134 pp. (1975).

Anderson, R.V., "Concentration of Cadmium, Copper, Lead, and zinc in Thirty-Five Genera of Freshwater Macroinvertebrates From the Fox River, Illinois and Wisconsin," Bulletin of Environmental contamination and Toxicology, 18(3):345-349 (1977).

Anderson, R.V., "Concentration of Cadmium, Copper, Lead and zinc in Six species of Freshwater Clams," Bulletin of Environmental Contamination a nả Toxicology, 18(4):492 (1977).

Anderson, R.V., H.S. Vinikour, and J.E. Brower, "The Distribution of $\mathrm{Cd}, \mathrm{Cu}, \mathrm{Pb}$ and $\mathrm{Zn}$ in the Biota of Two Preshwater sites with Different Trace Metal Inputs," Holarctic Bcology, 1:377-384 (1978).

Aubert, M.. et al.. "Utilization of a Trophodynamic chain of a Pelagic Type for the study of Transfer of letallic Pollution," Revue Internationale d'oceanographie Medicale, 28:27-52 (1972).

Aubert, M... et al.. "Use of a Neritic Trophodynamic Chain of Molluscs for the study of the Transfer of Metalic pollutants," $6 t h$ Symposium of the Internationale doceanographie Hedicale, Portoroz, Yugoslavia (Sept. 26-30, 1973): Revue Internationale doceanographie Medicale, 33:7-30 (1973). (NTIS CONF-7309103-1)

Bachman, R.H.. "Zinc-65 in studies of the Freshwater zinc Cycle," Radioecology, V. Schultz and A. H. Klement, Jr., (eds.), Reinhold, Washington, D.C., N.Y. and American Institute of Biological sciences, PD. $485-496$ (1963).

Ball. I.R.. "The Relative susceptibilities of some species of Freshwater Fisb to. Poisons II. Zinc," Water Research, 1:777-783 $(1967)$.

Barica, J.. M.P. Stainton, and.A.L. Hamilton, "Mobilization. of Some Metals in Water and Animal Tissue by NTA, EDTA and TPP," Water Research, 7:1791-1804 (1973). 
Barsdate, R.J.. "Pathways of Trace Elements in Arctic Lake Ecospstems," University of Alaska, Fairbanks, Institute of larine Science, (1972). (NTIS RLO-2229-T2-1)

Bartlett, L., F.W. Rabe, and H.H. Funk, "Effects of Copper, zinc

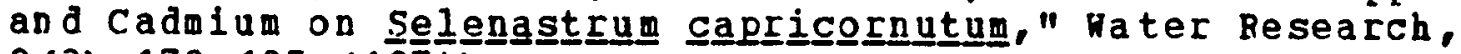
$B(3): 179-185(1974)$.

Bengtsson, B.-E., "Effect of zinc on the ability of the Minnow, phoxinus phoxinus $L$., to compensate for Torque in a Rotating water Current," Bulletin of Environmental Contamination and Toxicology, 12:654(1974).

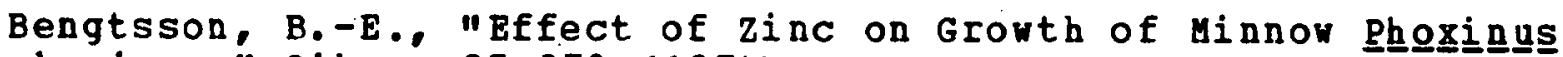
gh오iㅡㄴㅡ. " Oikos. 25:370 (1974).

Bengtsson, B.-E.. "Effect of zinc on the Movement Pattern of the

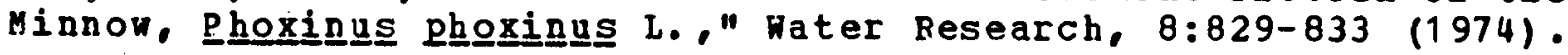

Bengtsson, B.-E.. "The Effects of zinc on the lortality and Reproduction of the Uinnow, Phoxinus phoxinus L." Archives of Environmental Contamination and. Toxicology, 2 (4):342-355 (1974).

Benifts-claus, C. and F. Benifts, "Effect of Low Lead and zinc Concentrations on the Larval Development of the vudcrab Rhith Chemicals on Aquatic Animals," Proceedings of the Swedish-Netherlands Symposium, Wageningen, Neth., 43 (1975).

Biesinger, K.E. and G.M. Christensen, "Effects of Various Metals on Survival, Growth, Reproduction, and Metabolism of Dạphni magna." Journal of the Fisheries Research Board of Canada, 29(12): 1691-1700 (1972).

Birge. W.J. and J.J. Just, "Sensitivity of Vertebrate Bmbryos To Heavy Metals as a Criterion of Nater Quality, "Kentucky Nater Resources Institute, Lexington (1973). (NTIS PB-226-850)

Birqe, W.J.. et al.. "Embryopathic Effects of waterborne and Sediment-Accumulated Cadmium, Mercury, and zinc on Reproduction and Survival of Fish and Amphibian Populations in Rentucky," Research Report 100, Water Resources Research Institute, oniversity of Kentucky. Lexington, 28 pp. (1977):

OHRT/A-061-KY (1), U.S. Department of Commerce, NTIS, springfield, Va. (1977).

Bondietti, E.A., et al.. "Ecological Research," Ecology and Analysis of Trace Contaminants, progress Report, October 1974-December 1975, W.D. Shults and R.I. Van Hook, (eds.), Oak Ridqe National Laboratory Report ORNL-NSF-EATC-22 (1976).

Boothe, P.N. and G.A. Knauer, "Possible Importance of Fecal Material in the Biological Amplification of Trace and Heavy Meta 1s," Limnology and Oceanography. 17(2):270-275 (1972). 
Bougis, P., "Physiological Effects of Zinc in Seawater," Chenical Abstracts, 56:1851 (1961).

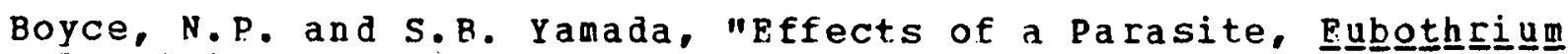
salvelini, (Cestoda Pseudophyllidea), on the Resistance of

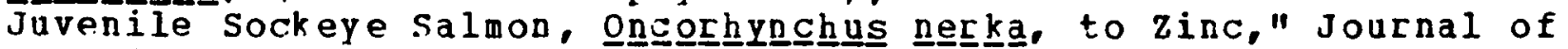
the Fisheries Research Board of Canada, 34:706 (1977).

Braek, G.S.G., J. Jensen, and A. Mohus, "Heavy Metal Tolerance of Marine Phytoplankton III. Combined Effects of Copper and zinc Ions on Cultures of Four Common species," Journal of Experimental Marine Bioloqy and Ecology, 25(1):37-50 (1976).

Brafield. A.F. and P. Matthiessen, "oxyqen Consumption by Sticklebacks (Gastergosteus aculeatus L.) Exposed to Zinc," Journal of Fish Biology, $9: 359(1976)$.

Brereton, A., et 31 . "Effect of $\mathrm{zinc}$ on Growth and Development of Larvae of the Pacific oyster 드모으느를 qigas," Marine Biology, 19(1): 96-101 (1973):

Brkovic-Popovic, I. and M. Popovic, "Fffects of Heavy Metals on Survival and Respiration Rate of Tubificid Worms: Part I Effects on Survival," Environmental Pollution, 13:65-72 (1977).

Brkovic-Popovic, I. and M. Popovic, "Effects of Heavy Metals on Survival and Respiration Rate of Tubificid Wor as: Part II -

Effects on Respiration Rate," Environmental pollution, 13:93-98 (1977).

Brown, B. E., "Effects of Mine Drainage on the River Hayle, Cornval1: A) Factors Affecting Concentrations of Copper, zinc and Iron in water. Sediments and Dominant Invertebrate Fauna," Hydrobiologia, $52(2 / 3): 221-233$ (1977); Biological abstracts, 13612 (1977):

Brown. B.E. and R.C. Newell, "Effect of Copper and zinc on the

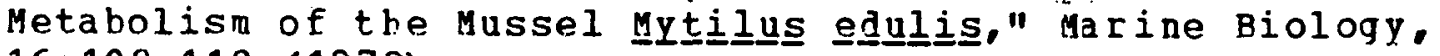
$16: 178-118$ (1972) .

Brown, V.M.. "The Calculation of the Acute Toxicity of Mixtures of Poison to Rainbow Trout," Hater Research, 2(10):723-733 $(1968)$.

Brown, V.M., "Aspects of Heavy Metals Toxicity in Fresh Waters," Proceedings of the International Joint Commission's Horkshop on Toxicity to Biota of Metal Porms in Natural Hater, october 7-8, 1975. Duluth, Minn.. pp. 59-75 (April 1976).

Brown, V.M. and R.A. Dalton, "The Acute Lethal Toxicity to Painhow Trout of Mixtures of Copper, Phenol, Zinc and Nickel," Journal of Fisheries Biology, 2:211-216 (1970). 
Brown, V.M., V.V. Mitrovic, and G.T.C. Clarke, "Effects of Chronic Exposure to zinc on Toxicity of a Mixture of Detergent and Zinc," Water Research, 2 (4):255-263 (1968).

Brown, V.M.. B.A. Tiller, and D.H.H. Jordan, "Acute Toxicity to Rainbow Trout of Fluctuating Concentrations and Mixtures of Ammonia, Phenol, and Zinc," Journal of Fish Biology, 1:1-9 (1969).

Brungs, H.A." "Chronic Toxicity of zinc to the Fathead Minnow, Pịephales promelas Rafinesque," Transactions of the American Fisheries society. 98:272 (1969).

Bryan, G.N.. "Metabolism of $\mathrm{zn}$ and $65 \mathrm{zn}$ in Crabs, Lobsters, and Freshwater Crayfish," Radioecological Concentration Processes, B. Aberq and F.P. Hungate (eds.), Pergamon, Oxford, England, pp. 1005-1016 (1966).

Bryan, G.W." "zinc Regulation in the Freshwater crayfish (Including some Comparative Copper analyses)." Journal of Experimental Biology, 46:281-296 (1967).

Bryan, G.W., "Some Aspects of Heary Metal Tolerance in Aquatic Organisms," A.P.M. Lockwood, (ed.). Cambridge Oniversity Press, N.Y., 35 pD. (1977).

Bryan, G.H. and I.G. Humerstone, "Adaptation of the Polychaete

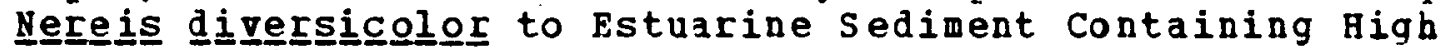
Concentrations of zinc and Cadmium." Journal of the Marine Biological Association of the United Kingdon, 53(4):839-857 (1973).

Bucke, D.. "Neoplasia in Roach (Rutilus rutílus L.) from a Polluted Environment," Progress in Experimental Tumor Research, 20:205 (1976).

Buikema, A.L., Jr., J. Cairns, Jr., and G.W. Sullivan,

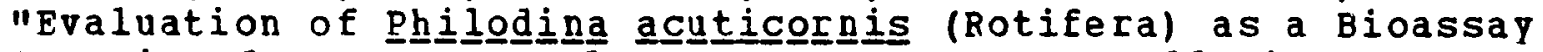
organism for Heavy Metals," Water Resources Bulletin. $10(4): 648-661 \quad(1974)$.

Burton, D.T., A.H. Jones, and J. Cairns, Jr., "Acute zinc Toxicity to Rainbow Trout (Sa almo gairgener i): Confirmation of the Hypothesis That Death is Related to Tissue Hypoxia," Journal of the Fisheries Research Board of Canada, 29(10):1463-1466 (1972).

Burton, D.T., E.I. Morgan, and J. Cairns, Jr., "Hortality Curves

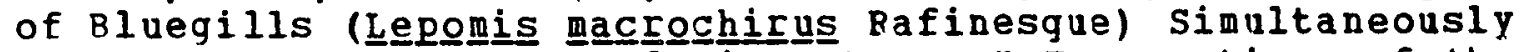
Exposed to Temperature and Zinc Stress." Transactions of the American Fisheries Society. 101 (3):435-441 (1972).

Cairns, J.. JI.." "Effects of Lapsed Time Since Feeding Upon the Toxicity of Zinc to Fish," Bulletin of Environmental

contamination and Toxicology, 13:269 (1975). 
Cairns, J., Jr. and K.L. Dickson, "Redustion and Restoration of the Number of Freshwater Protozoan species Following acute Exposure to Copper and zinc," Transactions of the Kansas Academy of Science, 73:1-10 (1970).

Cairns, J,, Jr. and A. Scheier, "Effects of Temperature and Hardnes of water Upon the roxicity of $Z$ inc to the common

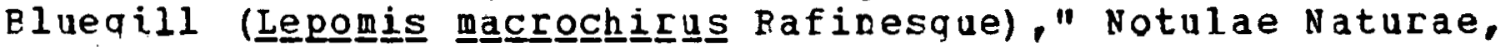
299: 12 (1957).

Cairns, J., Jr. and A. Scheier, "The Effects of Temperature and Hardness of water Upon the roxicity of zinc to the pond snail,

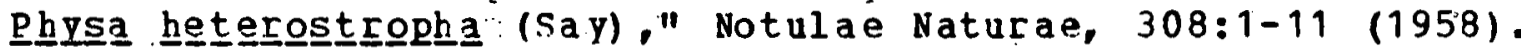

Cairns, J., Jr. and R.E. Sparks, "The use of Bluegill Breathing to Detect Zinc," U.S. Environmental Protection Agency Report EPA-18050-EDO (DeC. 1971). (NTIS PB-211332)

Cairns, J., Jr. and W.T. Waller, "The Use of Fish Movement Patterns to Monitor Zinc," U.S. Environmental Protection Agency Report EPA-18050-EDP (DeC. 1971). (NTIS PB-211333)

Cairns. J.. Jr.. et al.. "The Effects of oH, Solubility and Temperature Upon the Acute coxicity of zinc to the Bluegill

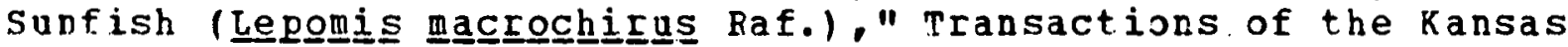
Academy of science, 74(1):81-92 (1971).

Calabrese, A.. et al., "Toxicity. of Heavy Metals to Bmbryos of the American oyster Cㄷassost $18: 162-166(1973)$.

Calabrese, A.. et al.. "Survival and Growtb of Eivalve Larvae under Heavy-Metal Stress," Marine Biology, 41:179-184 (1977).

Carson, W.G. and W.V. Carson, "Toxicity of Copper and Zinc to Juvenile Salmon in the Presence of Humic Acid and Lignosulfates," Fisheries Research Board of Canada MS Report No. 1181, 5 pp. $(1972)$.

Carter, J.W. and I.L. Cameron, "Toxicity Pioassay of Heavy Metals

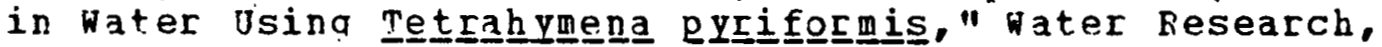
$7(7): 951-961(1 \overline{97} 3)$.

Chapman, G.. "Effect of Heavy Metals on Fish," oreqon State University Water Resources Research Report No. SEMN-WE-D16.73, pp. 141-162 (Jan. 1973).

Chipman, W.A., T.F. Rice, and T.J. Price, "Uptake and accumulation of Radioactive Zinc by Marine plankton, Fish, and Shellfish," J.S. Fish and Wildlife Service, Fisheries Bulletin, $135(58): 279-292$ (1958). 
Coleman, R.D.. P.L. Coleman, and E.I. Rice, "zinc and Cobalt Bioconcentration and Toxicity in selected algal species," Botanical Gazette, 132:102-109 (1971).

Conner, P.M.. "Acute Toxicity of Heavy Metals to Some Marine Larvae," Marine Pollution Bulletin, 3(12):190-193 (1972).

Cook, R.H. and R.P. Cote, "Influence of Rumic Acids on Toxicity of Copper and zinc to Juvenile atlantic Salmon as Derived from the Toxic onit Concept," Canadian Environmenta 1 Protection Service, US Report No. 72-2, 27 pp. (1972).

Cook, R.H...R.A.W. Hoos, and R. P. Cote, "Toxicity of Copper and Zinc to Atlantic Salmon; Laboratory and Field Evaluations with Special Emphasis on High Nater Hardness Concentrations," Canadian Research and Development Branch, MS Report 71-16,88 pp. (1971).

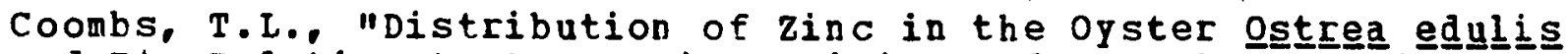
and Its Relation to Enzymatic Activity and to other letals," Marine Bioloqy, 12:170-178 (1972).

Coughtrey, P.J. and H.H. Martin, "The Uptake of Lead, zinc, Cadmium, and Copper by the pulmonate Mollusc, Helelix a aspers Muller, and Its Relevance to the Monitoring of Heavy Metal contamination of the Environment," Decologia, 27:65-74 (1977).

Crandall, C.A. and C.J. Goodnight, "The Effects of sublethal Concentrations of Several Toxicarts to the Common Guppy. Lebistes reti culataus." Transactions of the American Microscopical Society. $82: 59-73(1963)$.

cross, P.A. and J.H. Brooks, "Concentrations of Manganese, Iron; and Zinc in Juveniles of Five Estuarine-Dependent Fishes," Radionuclides in Ecosystems, Vol. 2, D.J. Nelson, (ed.), Proceedings of the 3rd. National Symposium on Radioecology, Oak Ridqe, Tenn.. pp. 769-775 (Hay 10-12, 1971). (Available from NTISI

Dean. J.M.. "Accumulation of $65 \mathrm{zn}$ and other Radionuclides by Tublficid Worms," Hydrohiologia, 45:33 (1974).

De I..G. Solbe, J.F., "Relation Between Water Quality and the Status of Fish Populations in Willow Brook," Water Treatment and Examination, $22(1): 41-61$ (1973).

De I.G. Solbe, J.F., "The Toxicity of zinc sulphate to Rainbow Trout in Verv Hard Water," Hater Research, 8(6):389-391 (1974).

De L.G. Solbe, J.F. and V.A. Cooper, "studies on Toxicity of Copper sulphate to stone lozch, Noemacheilus barbatulus (L.) in Hard Water," Nater Research, 10:52 3-527 (1.976). 
De I.G. Solbe, J.F. and V.A. Flook, "Studies on the Toxicity of

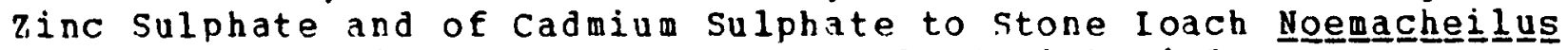

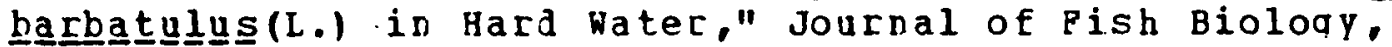
$7(4): 631-637(1975)$.

Deschiens, B., V. Molinari, and D. Bertirand, "Molluscacidal Action of 'Water of Zinc'."' Biological Abstracts, 32:5811 (1958).

Dilling. M.J. and C.W. Healey. "Influence of Lead and the Metallic Ions of Copper, 7inc, Thorium, Beryllium, and Thallium on the Germination of Frogs' spawn and on the Growth of Tadpoles," Anals of Applied Biology, 13(2):177-188 (1926): Biological Abstracts, 2:3485 (1928).

Eaton, J.G., "Chronic Toxicity of a Copper, Cadmium and zinc

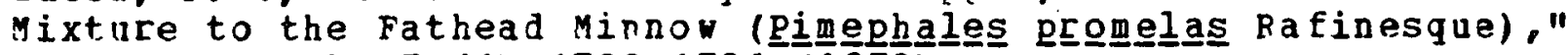
Water Research, 7(11):1723-1736 (1973).

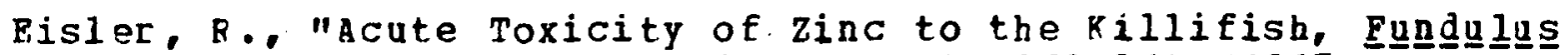

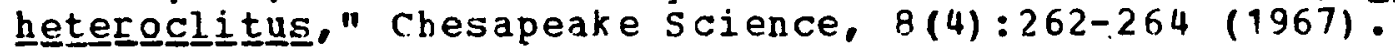

Eisler, R.. "Acute Toxicities of Selected Heavy Metals to the

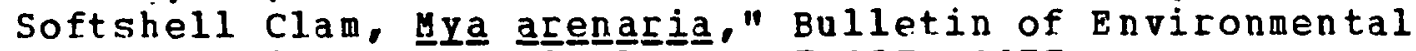

Contamination a na Toxicology, 17:137 (1977).

Eisler, R. and G.B. Gardner, "Acute Toxicology to an Estuarine Teleost of Mixtures of Cadmium. Copper, and zinc Salts," Journal of Fish Biology. 5:131-142 (1973).

Eisler, R. and R.J. Hennekey, "Acute Toxicities of Cd2+, Cr6+, Hg2+, Ni2+ and Zn2+ to Estuarine Macrofauna," Archives of Environmental Contamination and Toxicology, 6:315-323 (1977).

Fstablier, B. and, E. Pascual, "Studies on Copper, Iron,

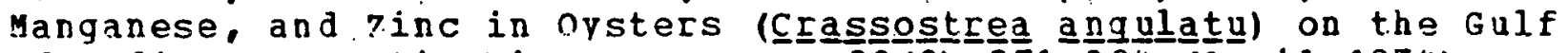
of Cadiz," Investigacion Pesquera, $38(2): 371-384$ (April 1974).

European Inland Fisheries Advisory Comission, "hater Quality Criteria for Puropean Freshwater Fish," Summary of a Report on Zinc and Freshwater Fish, EIFAC Technical Paper No. 21, Water Res ear ch, 8:683-684 (1974).

Federation of Sewage and Industrial wastes Associations, "Toxicity of copper and zinc Ions in tha Dilution BOD Test," Sewaqe and Industrial wastes, $28(9): 1168-1169$ (1956).

Frazier, J.M.. "The Dynamics of Metals in the American oyster,

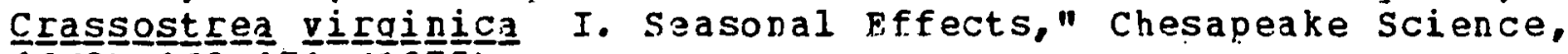
$16(3): 162-171$ (1975).

Prazier, J.4., "The Dynamics of Metals in the American Oyster,

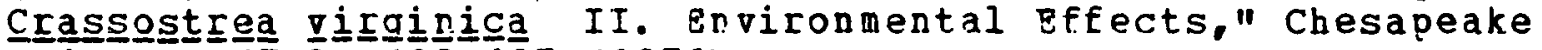
science, $17(\overline{3}): 188-197$ (1976). 
Gaechter, R., "Heavy Metal Toxicity and Synerqism to Natural Phvtoplankton in the Eutrophic Lake 1 pnach and the Mesotrophic Horw Bay," Schweizerische Zaitschrift fur. Hydroloqie, $38(2): 97$ $(1976)$.

Gardner, G.R.. "Chemically Induced Lesions in Estuarine or Marine Teleosts," Pathology of Fishes, W. E. Ribelin and G. Migaki, (eds.). University of Wisconsin Press, Madison, pp. 657-693 $(1975)$.

Goodman, J.R., "Toxicity of zinc for Rainbow Trout (Salmo gaidㅁe티)." California Fish and Game, 37 (2):191-194 (1951).

Grande, M.." "Effect of Copper and Zinc on Salmonid Fishes," Advances in Rater Pollution Research, Vol. I, Proceedings of the 3rd International Conference, Nater pollution Control Federation, Washingt on, D.C., Pp. 97-111 (1967).

Gray, J.S.. "Synergistic Effects of Three Heavy Metals on Growth Rates of a Marine Ciliate Protozoan," In: Pollution and Physiology of Marine Organisms, F.J. Vernberg and H. B. Vernberg, (eds.), Academic Press, New York, pp. 465-485 (1974).

Greene, J.C.. et al., "Toxicity of zinc to the Green Alga

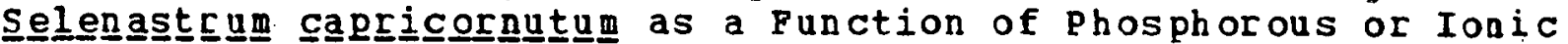
strenqth," proceedings of the Biostimulation and Nutrient Assessment workshop, Oct, 16-17, 1973, National Environmental Besearch Center, Corvallis, Ore., o.S. Environmental protection Aqency Beport EPA-660/3-75/034, pp. 28-43 (June 1975).

Gutnecht, J., "Mptake and Ratention of Cesium 137 and zinc 65 by Seaveeds," Iimnology and Oceanography, 10:58-66 (1965).

Hahne, H.C. and W. Kroontje, "Significance of pH and Chloride concentration on Eehavior of Heavy Metal pollutants: Mercury (II), Cadmium (II), Zinc (II), and Lead (II), "Journal of Environmental Quality, 2:444-451 (1973).

Harqreaves, J.W. and B.A. Whitton, "Effect of pH on Tolerance of

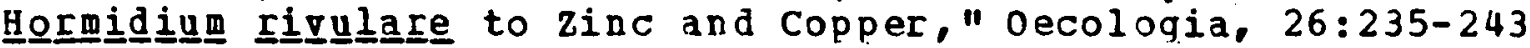
$(1976)$.

Harvey, R.S, and R. Patrick, "Concentration of 137Cs, 65zn, and 85Sr by Freshwater Alqae," Biotechnology and Bioengineering. $9: 449-456(1967)$.

He1z, G.R., R.J. Huggett, and J.M. Hill, "Beharior of In, Fe, Cu, Zn. $C d$, and $\mathrm{Pb}$ Discharged from a ristevater Treatment plant into an Estuarine Environment," Mater Research, 9:631-636 (1975).

Herbert, D.H.M. and D.S. Shurben, "The Toxicity to Pish of Mixtures of Poisons I. Salts of Ammonia and zinc," Annals of Applied Biology, 53:33-41 (1964). 
Herbert, D.M.M. and J.M. VanDyke, "The Toxicity to Fish of Mixtures of Poisons II. Copper-Ammia and Zinc-Phenol Mixtures," Annals of Applied Biology, 53:415-421 (1964).

Herbert, D.W.M. and A.C. Nakeford, "The Susceptibility of Salmonid Fish to poisons Jnder Estuarine Conditions I. Zinc Sulphate," International Journal of Air and water Pollution. $8: 251-256(1964)$.

Hiltibran, R.C.. "Effects of Cadmium, Zinc, Manganese, and Calcium on Oxygen and Phosphate Metabolism of Blueqill Liver Mitochondria," Journal of the Vater Pollution Control Federation. $43(5): 818-823(1971)$.

Hodson, P.V. and J.B. Sprague, "Terperature-Induced Changes in Acute Toxicity of Zinc to Atlantic Salmon (Sa of the Pisheries Research Board of Canada, $32(1): 1=10$ (1975).

Hoss, D.E., "Accumulation of zinc- 65 by F lounder of the Genus

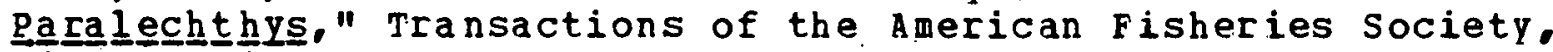
$93: 364-36 \frac{1}{8}(1964)$.

Hublou, W.F., J.W. Wood, and E.R. Jeffries, "Toxicity of Zinc or Cadmium for Chinook Salmon," Oregon Fish Commission, Research Briefs, $5(1): 8-14$ (1954).

Hutchinson, T.C. and H. Czyrskz, "Cadmium and zinc Toxicity and Spnergism to Floating Aquatic Plants," Water Pollution Research in Canada, 7:59-6.5 (1972).

Hutchinson, T.C. and H. Czyrska, "Heavy Metal Toxicity and Synergism to Floating aquatic Weeds," Verhandlungen

Internationale Vereinigung $f$ ur Theoretische und Angewunde Iimnoloqie, 19:2102-2111 (1975).

Ireland, M.P., "Result of Fluvial Zinc Pollution on the zinc Content of littoral and Sub-Littoral organisms in Cardigan Bay. wales," Environmental Pollution, 4:27-35. (1973).

Jackim. E.. "Influence of Lead and other Metals on Pish Delta-Aminolevulinate Dehydrase Activity, "Journal of the Fisheries Research Board of Canada, 30 (4):560-562 (1973).

Jenkins, D.W.." "Flow of Toxic Metals in the Environment," International Conference on Environmental sensinq and Assessment, vol. I. I as Vegas, Nev. (Sept. 14-19, 1975).

Jenne, E.A." "Controls on Mn, Fe, Co, Ni, Cu, and Zn Concentrations in Soils and Hater: The siqnificant Role of Hydrous Mn and Fe Oxides," Advanced Chemistry. 73:337-387 (1968). 
Jensen, A.. B. Rystad, and S. Melsom, "Heary Metal Tolerance of Marine Phytoplankton. I. The Tolerance of Three Algal Species to 7inc in Coastal Sea Water," Journal of Experimental Marine Biology and Ecology, 15(2):145-157 (1974).

Jones, J.R.E.. "The Relative Toxicity of Salts of Lead, zinc and

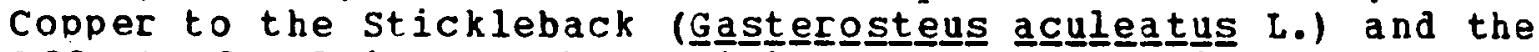
Refect of Calcium on the Toxicity of Lead and zinc Salts," Journal of Experimental Biology, 15:394-407 (1938).

Jones, J.R.E., "A Study of the Zinc Polluted River Ystwyth in North Cardiganshire, Hales," An nals of Applied Biology, $27: 368-378$ (1940).

Joyner, T.. "Exchange of Zinc with Environmental solutions by the Brown Bullhead," Transactions of the American Risheries Society. $90(4): 444-448 \quad(1961)$.

Joyner, T. and R. Eisler, "Retention and Translocation of Radioactive Zinc by Salmon Fingerlings," Growth, 25:151-156 (1961).

Kerfoot, M.B. and G.A. Redmznn, "Permissible Levels of Heary Metals in Secondary Effluent for Use in a combined sewage Treatment-Harine Agriculture system II. Development of Guidelines by Method of Additions," Proceedings of the Conference on wastewater Jse in the production of Food and Fiber, Oklahoma City, Okla., pp. 79-101 (March 5-7, 1974).

Knauer, G.A. and J.H. Martin, "Seasonal Variations of Cadmium, Copper, Manganese, Lead, and zinc in Water and phytoplankton in Monterey Bay, California," Limnology and Oceanography, 18 (4) 597-604 (1973).

Koelling, J.J.. "Relationship of Trace Elements to Algae Growth," Ph.D. thesis, Washington State oniversity, pullman (1971).

Kuenzler, F.J., "Flimination of Iodine, Cobalt, Iron and zinc by Marine Zooplankton," Symposium on Radioecology. D.J. Nelson and F.C. Evans, (eds.), Oak Ridge, U.S. Atomic Energy Commission Technical Information Division, pp. 462-473 (1969).

Lawrence, A.W., "Kinetics of Microbiologically Mediated Transformations of Heavy Metals in Aquatic Environments," Cornell University, Ithaca, N.Y., (1974). (NTIS PB-239 148)

Lebedeva, G.D. and R.A. Kuznetsova, "Absorption of Radioactive zinc by Freshwater Fish (an Experimental Investigation)," Gigiena i Sanitariya, 34:151-15.3 (1969). 
Lewis, S.D. and W.M. Lewis. "Effect of zinc and Copper on the

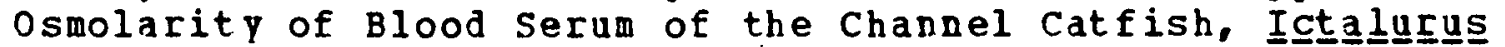
punctatus Rafinesgue, and Golden Shiner, Notemigonus chrysoleucas itchili," Transactions of the American Fisheries society, $100(4): 639-643$ (1971).

Lloyd, R.. "Toxicity of zinc sulphate to Rainbow Trout," Annals of Applied Biology, $48(1): 84-94$ (1960).

Lloyd; R:. "The Toxicity of Mixtures of Zinc and Copper sulfates to Rainbow Trout (Salmo gaíraneri Richardson). "Annals of applied Biology, 49:535-538(1961).

Lorz, H. and B.P. McPherson, "Effects of Copper and zinc on Smoltification of Coho Salmon," 0.S. Environmental protection Agen CY, EPA-600/3-77-032, Corval1is, Ore. (1977) . (NTIS PB-268 304)

Lu, P.. et al.. "Model Ecosystem Studies of Lead and Cadmium and of Urban Sewage sludge containing These Elements," Journal of Bnvironmental Quality, 4:505 (1975).

McIntosh, A. and H. Bishop, "Distribution and Effects of Heary Metals in a Contaminated Lake," Technical Report No. 85 . ORRT/A-036-IND (1), U.S. Department of Commerce, NTIS, Springfield, Va. (1976).

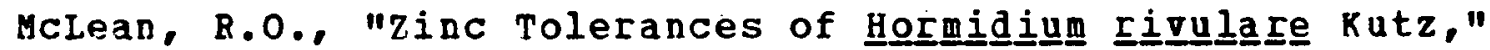
British Phycology Journal, 10:3.13 (1975).

Matthiessen, P. and A.E. Brafield, "The Effects of Dissolved Zinc on the Gills of the Stickleback Gasterosteus a Journal of Fish Biology, 5:607-613 (1973).

Matthiessen, P. and A.E. Brafield, "Uptake and Loss of Dissolved

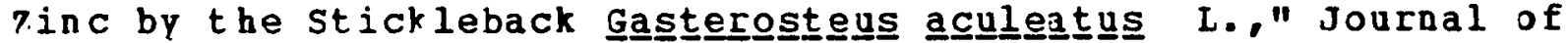
Fish Biology, 10(3):399-410 (1977).

Merlini, M.. et al.. "The Biological Pathway of zinc (65Zn) in Freshwater Pish and Its Alteration by Heavy Metals,"

Radionuclides in Ecosystems, Vol. I, D.J. Nelson, (ed.), Proceedings of the 3rd National Symposium on Radioecology, Oak Ridge, Tenn., pp. 285-306 (May 10-12, 1971). (Available from NTIS)

Mills, H.L." "Water Quality Bioassay Usina select Protozoa II. The Effects of Zinc on Population Growth of Euglena," Journal of Environmental science and Health, A $11(8 / 9): 567-572$ (1976).

Morqan, E.L., D.T. Burton, and J. Cairns, Jr.. "A Time Until Death study of Bluegill sunfish (Lepomis magrochirgus Rafinesque) Exposed to simultaneous Thermal and zinc stress," ÁsB Bulletin, $18(2): 47$ (1971). 
Morqan, R.P., II., et al., "Sublethal Effects of Baltimore Harbor Water on the lhite Perch, Morone a mericanga, and the Hogchoker,

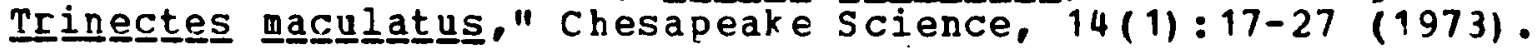

Morry, C.J. and L.J. Cole, "Limnology and Fish Populations of Red Indian Lake, a Multi-Use Reservoir." Technical Report No. 691. Fisheries and Marine Service, Environment Canada, St. John's, New found land, (1977).

Mount, D.I.. "Effect of Total Hardness and pH on Acute Toxicity of zinc to Fish," International Journal of Air and water Pollution, 10:49-56 (1966).

Nakani, D.V. and M.N. Korsak, "Effect of Chromium, Cadmium, and zinc on the Rate of Photosynthesis in Short-Term Experiments," Bioloqicheskie nauki, 19(9):84 (1976).

Nakatani, R.E., "Biological Responses of Rainbou Trout (Sal $\underline{\text { mo }}$ gairdneril Inqesting Zinc-65," Disposal of Radioactive wastes in Seas, Oceans, and surface Waters, IAEA, Vienna, pp. 809-823 $(1966)$.

Namminga, H.E., J.E. Scott, and S.I. Burks, "Distribution of Copper, Lead, and zinc in selected components of a Pond Ecosystem," Proceedings of the oklahoma Academy of Science, $54: 62-64(1974)$.

Negilski, D.S. "Acute Toxicity of Zinc, Cadmium and Chromium to

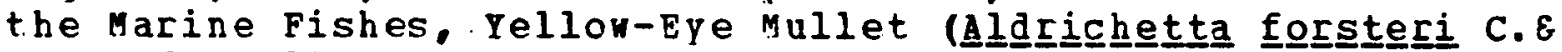
V.) and Small-Houthed Hardyhead (Atherinasoma microstoma Whitley)." Australian Journal of Marine and Freshwater Research. $27: 137$ (1976).

Nehring, R.B. and J.P. Goettl, Jr., "Acute Toxicity of a zinc-Polluted stream to Four Species of Salmonids," Bulletin of Environmental Contamination and Toxicology. $12(4): 464-469$ (1974).

o'Rear, C.W., Jr.. "Some. Environmental Influences on the zinc and

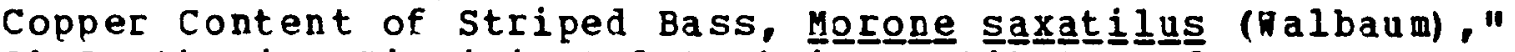

Ph.D. thesis, virginia Polytechnic Institute and state Iniversity, Blacksburg, 70pp. (1971).

overnell, J., "Inhibition of Marine Algal Photosynthesis by Heary Metals," Marine Biology, 38:335 (1976).

Patrick, F.M. and M. N. Loutit, "Passage of Metzls in Effluents, Through Bacteria to Higher Organisms," Water Research, 10:333-335 $(1976)$.

patrick, R.. J. Cairns, Jr., and A. Scheier, "Relative Sensitivity of Diatoms, snails, and Fish to rwenty Common constituents of Industrial Wastes," Progressive Fish-culturist, $30(3): 137-140$ (1968). 
pentreath, R.J." The Accumulation and Retention of $65 \mathrm{zn}$ and $54 \mathrm{mn}$ by the Plaice, pleuronectes platessa L.," Journal of Experimental Marine Biology and. Ecology, 12(1):1-18 (1973).

Pentreath, R.J." "The Accumulation from Water of 65z n, 548n, $58 \mathrm{Co}, 59 \mathrm{Fe}$ by the Mussel yytilus edulis," Journal of the Marine Biological Association of the United Kingdom, 53:127-143 (1973).

Phillips, D.J.H., "Common ussel Mytilus edulis as an Indicator of Pollution by zinc, Cadmium, Lead, and Copper I. Effects of Environmental. Variables on Uptake of Metals," Harine Biology, $38: 59-69(1976)$.

Phillips, D.J.H., "Rffects of salinity on the Net Optake of Zinc

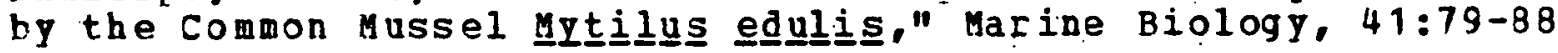
(1977).

Pickering, Q.H., "Some Effects of Dissolved oxygen Concentrations

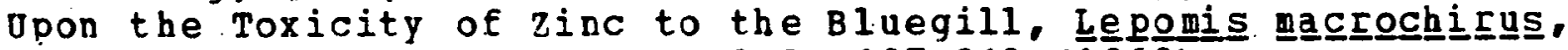
Rafinesque," Dater Research, 2(3):187-213 (1968).

Pickering, Q.H. and $C$. Henderson," "Acute Toxicity of Some Heary Metals to Different Species of Narm Nater Fishes." International Journal of Air and hater Pollution. 10:453-463 (1966).

Pickering, Q.H. and H.N. Vigor, "Acute Toxicity of Zinc to Eqgs and Fry of the Fathead Minnow," Progressive Fish-Culturist, $27(3): 153-157$ (1965).

poon. C.P.C. and K.H. Bhayahi. netal Toxicity to sewage organisms, "proceedings of the American society of civil Engineers, Journal of the Sanitary Engineering Division, Vol. 97 $(1970)$.

Porter, K.R. and D.E. Hakanson, "Toxicity of Mine-Drainage to Fmbryonic and Larval Boreal Toads (Bufonidae: Bufo bogregs , " Copeia, $2: 327-331$ (1976).

Rabe, F. W. and C.W. Sappington. "Acute Toxicity of Zinc to Cutthroat Trout, Salmo clakㅗ‥" Biological productivity of the Coeur d'alene River as Related to Rater Quality, Completion Beport for the water Resources Research Institute, oniversity of Idaho, Moscow, pp. 1-16 (1970); Sport. Fishing Abstracts, No. $13665(1971)$.

Babe, F.H., R.C. Wissmar, and K.F. Winter, "Plankton Populations and Some Effects of Mine-Drainage on Primary Productivity of the Coeur d'Alene River, Delta, and Lake," oniversity of Idaho, Water Resources Institute Completion Report, Moscow, 20 pp. (1973). (NTIS PB-216 211)

Rachlin, J.W. and M. Parran. "Growth Besponse of the Green Algae Chlorelia vulgaris to Selective Concentrations of Zinc," Nater pesearch, 8:575-577 (1974). 
Rachlin, J.W. and A. Perlmutter, "Response of an Inbred Strain of Platyfish and the Fathead Minnow to Zinc," Progressive Fish-Culturist, $30: 203-207$ (1968).

Rachlin, J.W. and A. Perlmutter, "Response of Rainboy Trout Cells in culture to selected concentrations of zinc sulfate."

Progressive Fish-Culturist, 31:94-98. (1969).

Ray. S. and W. White, "Selected Aquatic plants as Indicator species for Heavy Metal pollution," Journal of Environmental Science and Health, A-11(12):717-725 (1976).

Rehwoldt, R., G. Bida, and 3. Nerrie, "Acute Toxicity of Copper, Nickel and Zinc Ions to some Hudson Biver Fish Species," Bulletin of Enviconmental Contamination and Toxicology, 6(5):445-448 (1971):

Rehwoldt, R.. et al.. "Effect of Increased Temperature Opon the Acute Toxicity of Some Hearr Metal Ions," Bulletin of Enviconmental contamination and Toxicology, 8(2):91-96 (1972) .

Rehwoldt, R., et al.. "The Acute Toxicity of Some Heary Metal Ions Toward Benthic Organisms," Bulletin of Environmental Contamination and Toxicology, $10(5): 291-294$ (1973).

Reish, D.J., et al.. "The Effect of Heary Metals on Laboratory Populations of Two polychaetes vith Comparisons to the later Quality Conditions and Standards in Southern California Marine Waters," Water Research, 10:299-302 (1976).

Renfro. W.C.. "Transfer of $65 \mathrm{Zn}$ from Sediments of Marine Polychaete Worms," Marine Biology, 21(4):305-316 (1973).

Renfro; H.C., R.V. Phelps, and T.F. Guthrie, "Influence of Preservation and Storage on Radiozinc and Total zinc Concentrations in Pish," Iimnology and Oceanography, 14:168-170 (1969).

Renfro, N.C., et al., "Relative Importance of Food and Hater Pathways in the Bioaccumulation of zinc," International Atomic Enerqy agency Technical Report IAEA-163, pp. 11-20 (1974).

Roales, B.B. and A. Perlmutter, "Toxicity of Zinc and Cygon, Applied Singly and Jointly, to Zebrafish Embryos," Bulletin of Environmental Contamination and Toxicology. 12 (4):475-480 (1974).

Romeril, M.G.. "Optake and Distribution of Zn65 in Oysters," Marine Bioloqy, 9:347-354 (1971).

Rosco, J.J. and J.M. Rachlin, "Effects of Copper, Zinc, Cobalt, and Manganese on the Growth of the Marine Diatom Nitzzchia closteriun." Bulletin of the Torrey Botanical Club, 102:100 $(1975)$. 
Ruthven, J.A. and J. Cairns, Jr., "Response of Fresh-Hater Protozoan Artificial Communities to Metals," Journal of Protozoology, 20(1):127-135 (1973) :

Sabodash; V.M. "The Size of Eggs and Larvae from Carp Females of Different ages onder Normal Conditions and Inder the Effect of Elevated Concentrations of zinc Sulphate," Biologicheskie nauki, 3:62-67 (1977); Aguatic Sciences and Fisheries abstracts, $7(9): 7011415$ (1977).

Saiki, M. and T. Mori, "Studies on the Distribution of Aduinistered Radioactive zinc in the Tissues of Fishes," Bioloqical Abstracts, $31: 23,478$ (1957).

Saliba, L.J. and R.M. Krzyz, "Fffect of Heary Metals on Hatching of Brine Shrimp Eggs," Marine Pollution Bulletin, 7(10):181-182 $(1976)$.

Salzinger, K., et al., "Behavior of the Goldfish as an Early warning Systew for the presence of pollutants in Mater," Journal of Environmental systems, 3(1):27-40 (spring 1973).

Sappington, C.W.. "The Acute Toxicity of zinc to cutthroat Trout," M.S. thesis, oniversity of Idaho (1969).

Sartory, D.P. and B.J. Lloyd, "The Toxic Effects of Selected Heavy Metals on onadapted Populations of Vorticella cong Var Similis," Water Research, 10:1123 (1976).

Saunders, R.L. and J.B. Sprzgue, "Effects of Copper-Zinc Mining Pollution on a spawing vigration of Atlantic salmon," Water Research $1(6): 419-432$ (1967).

Scheler, A. and P. Kiry, "A Discussion of the Effects of Certain Potential Toxicants on Fish and Shellfish in the opper Delaware Estuary." Academy of Natural Sciences of Philadelphia, Penn. (Dec. 1973). (NTIS PB-231 423)

Schott. W.." "Sensitivity of Trout to zinc," Water Pollution A bstracts, 26:1142 (1953).

Sellers, C.M., A.G. Heath, and H.I. Bass, "The Effect of Sublethal Concentrations of Copper and $z$ inc on ventilatory Activity. Blood oxygen and $\mathrm{pH}$ in Rainbow Trout (Sa 1 mo gairdneri)." Water Research, 9:401-408 (1975).

Shaikh, Z.A. and $0 . J$. Lucis, "Biological Differences in Cadmium and zinc Turnover," Archives of Environmental Health, 24:410-418 (19.72).

Sinley, J.R., J.P. Goettl, JI., and P.H. Davies, "The Effects of Zinc on Rainbow Trout ( a a $\underline{\text { Ino }}$ ga Bulletin of Environmental Contamination and Toxicology. $12(2): 193-201(1974)$. 
Skidmore, J.F.. "Toxicity of zinc Compounds to Aquatic Animals, with Special Reference to Fish," Quarterly Review of Biology. 39 (3): $227-247(1964)$.

Skidmore, J.F.. "Resistance to zinc sulphate of the Zebrafish

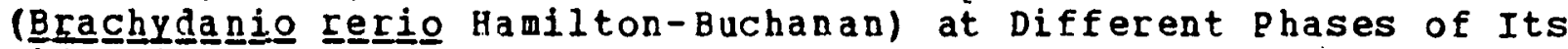
Life History," Annals of Applied Biology, 56 (1):47-53 (1965).

skidmore, J.F.. "Resistance to Zinc sulfate of Zebrafish (Brachhydangio reㄷiog) Embryos After Removal or Rupture of the juter Egq Membrane," Journal of the Fisheries Research Board of Canada, $23(7): 1037-1041(1966)$.

skidmore, J.F.. "Respiration and osmoregulation in Rainbow Trout with Gilis Damaged by Zinc Sulfate," Journal of Experimental Biology, $52(2): 481-494$ (1970).

Skidmore, J.F. and P.W.A. Tovell, "Toxic Effects of Zinc suifate on the Gills of Rainbow Trout," Water Research, 6(3):217-230 (1972).

Slater, J.V.. "Comparative Accumulation of Radioactive zinc in Young Rainbow, Cutthroat and Brook Trout," Copeia, 27: 158-161 (1961).

Small, L.F. and S.W. Powler, "Turnover and Vertical Transport of Zinc by the Euphasiid Meganyctiphanes norgegica in the Ligurian sea," Marine Biology, 18:284-290 (1973).

Sodergren, S.. "Ecological Effects of Heavy Hetal Discharge. in a Salmon River," Drottningholm, Sweden, Institute of Freshwater Research, Report 55:91 (1976).

Sparks, R.E.. "Using the Respiratory Responses of Bluegill Sunfish (Lepomis macrochirus Rafinesque) to Monitor Zinc Concentrations in Water," $\mathrm{Ph}$. D. thesis, oniversity of Michigan. Ann Arbor $(1971)$.

Sparks, R.E., J. Cairns, Jr., and A.G. Heath, "Use of Bluegill Breathing Rates to Detect Zinc," Nater Research, 6:895-911 (1972).

Sparks, R.E., A.G. Heath, and J. Cairns, Jr.. "Some Effects of Zinc on the EKG and Breathing Signal of Bluegills (Lepomis macㅗㅇㅡhㅗ프노 Rafinesque)," ASB Bulletin, 16(2):69 (1969).

Sparks, R.E., W.T. Haller, and J. Cairns, Jr., "Effect of Shelters on the Resistance of Dominant and subrissive Bluegilis

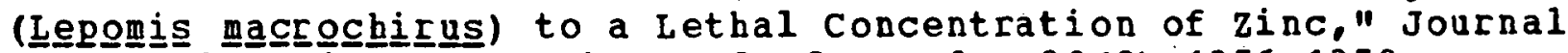
of the pisheries Research Board of Canada, 29 (9):1356-1358 (1972). 
Sparks, R.E.. et al.. Monitoring Zinc Concentrations in Water

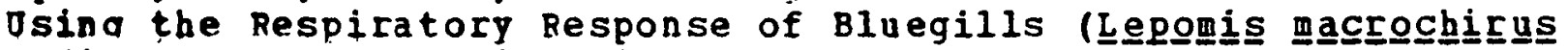
Ratinesquel." Hydrobiologia, 40 (3):361-369 (1972).

Spebar, R.I.. "Cadmium and Zinc Toxicity to Jordanella fla (Goode and Bean): Effects on Growth, Reproduction, Survival, and Behavior," Thesis, Oniversity of Minnesota (1974).

Spehar, R.I.. "Cadminn and zinc Toxicity to flagfish, Jordanellia flor idae." Journal of the Pisheries Research Board of Canada, 33:1939=1945 (1976).

Spehar. R.I.. "Cadmium and zinc Toxicity to Jorgananell O.S. Environmenta 1 Protection Agency Report EPA-600/3-76/096 $(1976)$.

Speranza, A.H., et al.. "The Effect of Sublethal Concentrations of zinc on Reproduction in the Zebrafish (Brachydanio rerio Haditon-Buchanan)." Environmental Pollution., 12:217 (1977).

Spraque, J.B.. "Avoldance of Copper-zinc solutions by Young Saloon in the Laboratory," Journal of the Hater Pollution Control Pederation, 36:990 (1964).

Spraque, J.B. . "lethal concentrations of Copper and zinc for Young Atlantic Salmon," Journal of the Fisheries Research Board of Canada, 21:17-26(1964).

Spraque, J.B.. "Effects of Sublethal concentrations of zinc and Copper on Migration of Atlantic Salmon." Biological problems in Dater pollution, Third Seminar, Cincinnati, Ohio, O.s. Public Healtb Service Publishing No. 999-wP-25, pp. 332-333 (1965).

Spraque, J.B.. "Avoidance Reaction of Rainbow Trout to Zinc Sulphate Solutions," Nater Research, 2:367-372 (1068).

Spraque, J.B.. "Promising anti-Pollutant: Chelating agents NTA protects Fish from Copper and ?inc," Nature, 220:1345-1346 $(1968)$.

Spraque, J.B. and B.A. Ransay, "Lethal Levels of Mixed Copper-zinc solutions for Juvenile Salmon," Journal of the Flsheries Research Board of Canada, 22:425 (1965).

Spraque, J.B.. P.F. Elson, and R.L. Saunders, "Sublethal Copper-zinc pollution in a Salmon River - A Field and Laboratory Study." International Journal of Air and nater pollution, 9: $531-543(1965)$.

Sreenivasah, A. and R.S. Raj, "Toxicity of zinc to Fish," Current science (India), $32(8): 363$ (1963). 
Stein, J.N. and M.D. Miller, "An Investigation into the Effects of a zinc-Lead Mine in the aquatic Environment on Great slave Lake," Technical Feport, Besource Management Branch, Department. of the Environment Pisheries and Marine Service, Winnipeg, Manitoha, $56 \mathrm{pp}$. (1972).

Sullivan, G.H., "Acute Bioassays for Assessing the Toxicity of Six Heavy Metals and Factors Affecting zinc Toxicity to the Rotifer, Phhillodina (nea Polytechnic Institute and state Oniversity. Blacksburg, (1973).

Sullivan, G.H. and A.L. Buikema, "The Effect of Hardness on the Toxicity of Zinc sulfate to the Rotifer Philiodina sp. " ASB Rulletin 19:104 (abstract) (1972).

Tabata, K., "Studies on the Toxicity of Heary Metals to Aquatic Animals and the Factors to Decrease the Toxicity $I$. On the Formation and the Toxicity of Precipitates of Heary netals," Bulletin of Tokai Regional Eisheries Research Laboratory,

58:203-214 (1969).

Tabata, K., "Studies on the Toxicity of Heary Metals to Aquatic Animals and the Factors to Decrease the Toxicity II. Antaqonistic action of Hardness Components in water on the Toxicity of Heary Metal Ions," Bulletin of Tokai Regional Fisheries Research Laboratory, 58:215-232 (1969).

Tabata, K.. "Studies on the Toxicity of Heavy Metals to Aquatic Animals and the Factors to Decrease the roxicity IV. On the Relation Between the Toxicity of Heary Metals and the Quality of Environmental Water," Bulletin of Tokai Regional Fisheries Besearch Laboratory, 58:243-253 (1969).

Thorp, V.J. and P.S. Lake, "Toxicity Bioassays of Cadmium on Selected Preshwater Invertebrates and the Interaction of Cadmium and Zinc on the Freshwater Shrimp, Paratyya tasmanieng Australian Journal of Marine and Freshwater Besearch, $25(1): 97-104(1974)$.

Trollope, D.P. and B. Evans, "Concentrations of Copper, Iron, Lead, Nickel and zinc in Freshwater Algal Blooms," Environmental Pollution, 11:109-116 (1976).

0.S. Department of the Interior. "zinc in water - A Bibliography," office of Water Resources Research Report WRSIC 71-208, $138 \mathrm{pp}$. (July 1971). (NTIS PB 201272)

Van Loon, J.C. and R.J. Beamish, "Heavy Metal Contamination by Atmospheric Fallout of Several Flin Flon Area Lakes and the Relation to Fish Populations," Journal of the Fisheries Research Board of Canada, 34:899 (1977). 
Vinikour, W.S., "Concentrations of zinc, Copper, Cadmium, and lead in selected Fish species of the Pox River from Locations with Varying Potential Metal Inputs," M.S. thesis, Northern Illinois oniversity, DeKalb, $103 \mathrm{pp}$. (Dec. 1977).

Vladimirov, V.I.. "Dependence of the Embryonic Development and Viability of the carp on the Trace Element zinc," problems in Ichthyoloqy, 9 (5):687-696 (1969).

Waller, W.T. and J. Cairns, Jr.. "nse of Fish Movement Patteras to Monitor Zinc in Nater," Nater Research, 6:257-269 (1972).

Warnick, S.I. and H.L. Bell, "Acute Toxicity of Some Heavy Metals to Different species of Aquatic Insects," Journal of the water pollution Control Federation, 41 (2):280-284 (1969).

water pollution Research Laboratory, stevenage, England, "Fish and water Quality Criteria," Notes on Nater pollution, No, 65 (June 1974).

Datson, T.A. and B.A. Mckeown, "The Effects of Sublethal Concentrations of zinc on Growth and Plasma Glucose Levels in

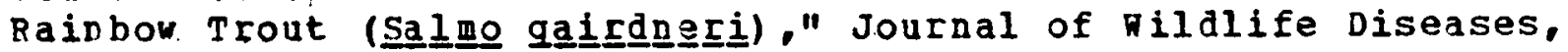
$12: 263(1.976)$.

Hedemeyer, G., "Uptake and Distribution of $2 \mathrm{n} 65$ in the Coho Salmon Eqg (Oncorhynchus kisutch)." Comparative Biochepistry and Physiolooy, $26(1): 271-279(1968)$.

Whitton. B.A.' "Toxicity of zinc, Copper, and Lead to Chlorophyta from Flowing Haters," Archiv fuer Uikrobiologie, 72:353-360 $(1970)$.

Mildish, D.J., W.G. Carson, and W. V. Carson, "The Effect of Humic

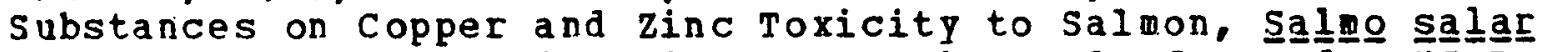
L.." Journal of the Fisheries Research Board of Canada, MS Report $1160,8 \mathrm{pp} .(1971)$.

Williams, L.G. and D.I. Mount, "Influence of zinc on periphyton Communities," American Journal of Botany, $52(1): 25-34$ (1965).

yisely, B. and R.A.P. Blick, "Mortality of Marine Invertebrate Larvae in Mercury. Copper, and zinc Solutions," Austrailian Journal of Marine and Freshwater Research, 18(1):63-72 (1967) .

Holfe, D.A., et al., "The Plux of Hn, Fe, and $\mathrm{Zn}$ in an Estuarine Ecosystem," Proceedings of the symposium on Radioactive Contamination of the Marine Environment, International Atomic Energy Agency, Seattle, Mashington, 159 pp. (1973).

Wurtz, C.B., "zinc Effects on Freshwater Mollusks," Nautilus, $76(2): 53-61(1962)$. 
Yound, M.L., "Transfer of $65 \mathrm{zn}$ and 59Pe Along Tro Marine Food Chains," Ph.D. thesis, Univarsity of East Anglia, Norwich, England (1974).

7itko, V. and W.G. Carson, "A Mechanism of the Effects of Water Hardness on the Lethality of Heary letals to Pish," Chemosphere, 5: 299-303 (1976).

zitko, V. and W.G. Carson, "Seasonal and Developmental Variation in the Lethality of zinc to Juvenile atlantic salmon (salano salar ${ }^{2}$," Journal of the Pisheries Research Board of Canada, $34: 139(1977)$. 


\section{AUTHOR INDEX}

Abbott, 0.J. 7, 70, 178

Abegg, R. 98, 130

Academy of Natural Sciences 7, 70

Ackefors, H. 158

Ad ams, E.S. 145

Ad ams, W.J. 194

Adelman, I.R. 7, 98, 130, 201

Adema, D. 117

Affleck, A.J. 208

Ahsanul lah, M. 7, 81, 123, 208

Aiba, S. 49, 104, 125

Akiyama, A. 158

Alabaster, J.S. 70

Alberts, J.J. 45, 93, 104, 175

Alderdice, D.F. 76

Alekseenko, V.A. 7, 145, 208

Alekseyev, V.A. 189

Alexander, M. 77

Amend, D.F. 158,174

Ami ard, J.C. 7, 75, 105, 197, 199

Anderson, B.G. 7, 70, 76, 80, 97, 130,199

Anderson, J.B. 165

Anderson, R.A. 7, 81, 107, 180, 208

Anderson, : R.0. 75

Anderson, R.V. 7, 8, 81, 82, 107 , $108,145,209$

Andrew, R.W. 8, 105, 108, 131

Angelovic, J.W. 136

Antia, N.J. 80

Anwar, R.A. 8, 82, 98

Appalachian Regional Commission 8, 59

Appelgate, V.C. 8

Apts, C.W. 115

Arima, K. 76

Arkin, G.F. 73

Armstrong, F.A.J. 17.5

Aronson, A:L. 145

Arthur, J.W. 108

Ase11, B. 163

Ashley, L.M. 141

Ashton, W.M. 180

Associate Committee on Scientific

Criteria for Environmental Quality 98

Attman, L.C. 184

Atton, F.M. 177

Aubert, M. 8, 98, 108, 145, 158, 209

Bass-Becking, L.G.M. 183
Bacci, E. 174

Bachman, R.W. 209

Backe, C.A. 158

Baker, J.T.P. 108

Baker, R.A. 78

Baksi, W.F. 60

Bal1, I.R. 70, 82, 209

Banerjee, S.C. $47,67,74,134,188$, 202,206

Bard, C.C. 197

Barica, J. $8,98,108,141,145$, 155,209

Barnes, H. $8,108,158$

Barnes, M.E. 174

Barsdate, R.J. 8, 108, 145, 209

Barthel, J. 192

Bart lett, L. $8,82,108,210$

Bass, M.L. 45, 124, 223

Batch, D.L. 11

Bates, R. 28, 62

Battelle Pacific Northwest

Laboratories 9, 159

Batterman, A.R. 162,184

Baughman, G.L. 159

Beal, A.R. 194

Beamish, R.J. 9, 53, 59, 126, 183, 226

Beath, O.A. 196

Beauchamp, J.J. 21

Becker, A.J., Jr. 141, 200

Becker, C.D. 3, 9

Beer, W.D. 189

Beers, J.R. 108

Bell, H.L. 54, 59, 94, 105, 144, $153,183,227$

Be11a, D.A. 201

Ben-Bassat, D. 159

Benayoun, G. 82, 86, 195

Benes, P. 9

Bengtsson, B.-E . 82, 210

Benijts-C1 aus, C. 9, 146,210

Benijts, F. 9, 146, 210

Bennett, H.T. 20

Benoit, D.A. $82,99,109,119$

Benoit, R.J. 104, 105

Bent ley-Mowat, J.A. 9, 109

Beppu, M. 76

Berland, B.R. 9

Bertrand, D. 215

Betz, M: 159

Betzer, S.B. 109 
AUTHOR INDEX (Contd.)

Beyerly, G.B. 109

Beyers, R.J. 167, 168, 175

Bhayahi, K.H. $42,103,122,181$, 198,221

Bible, J.L. 59

Bida, G. $43,122,181,222$

Bieb 1, R. 131

Bielig, H.J. 208

Biesecker, J.E. 9

Bies inger, K.E. $10,79,82,105$, $108,109,131,141,159,180,210$

Bilinski, E. $10,82,109$

Binet, L. 131, 159

Birge, W.J. $10,80,83,146,159$, 210

Bishop, J.N. 160

Bishop, W. $35,90,102,150,219$

Bisogni, J.J., Jr. 160,183

Bittner, M.A. 139,191

Blaber, S.J.M. 135

Black, G.A.P. 109

Black, I.H. 61

Black, J.A. 80,109

Blanton, C.J. 160

Blanton, W.G. 160

Blaxter, J.H.S. 109

B1 aylock, B.G. $10,28,88,166$

Blick, R.A.P. $56,127,178,227$

Bligh, E.G. 160

Blinn, D.W. 176

Bloomfield, R.A. 75

Boccardy, J.A. 10

Bodine, J.H. 95, 97, 131, 194, 199

Boetius, J. 160

Boisseau, D. 116

Bolts, J.C. 55

Bondietti, E.A. $10,83,210$

Boney, A.D. 160

Bonn, E.W. 201

Boothe, P.N. 11, 76, 83, 99, 105, $109,141,146,155,210$

Boschetti, M.M. 76

Bothner, M.H. 11, 160, 203

Bott, T. 41

Bougis, P. 211

Bovee, E.C. $11,83,95,110,141$

Bowen, H. J. M. 11

Boyce, N.P. 211

Boyden, C.R. 11

Boyer, J.F. 11, 59, 183

Braek, G.S.G. 11, 110, 154, 211
Brafield, A.E. $96,211,219$

Braman, R.S. 76

Brandt, H.J. 189

Branson, B.A. 11

Bremmer, I. 11

Brereton, A. 211

Brett, J.R. 76

Brezina, E.R. 12, 59

Brezonick, P.L. $16,77,80$

Bridges, h.R. 128

Bringmann, G. 12, 75, 99, 110, 136, 178,194

Brkovic-Popovic, I. $12,66,83,99$, $110,137,160,179,180,211$

Broberg, S. 192

Broda, E. 90

Broderius, S.J. 128, 129, 180, 183, 201

Brooks, J.H. 18, 141, 155, 214

Brower, J.E. 82, 108, 145, 209

Brown, A.C. 201

Brown, B.E. 12, 110,141, 146, 211

Brown, H.W. 62

Brown, V.M. $12,13,46,66,70,83$, $99,110,111,124,128,131,137$,

$146,179,180,183,189,190,203$, 211,212

Browning, E. 13

Brungs, W.A. 13, 111, 131, 184, 212

Bruun, L.H. 125.

Bryan, G.W. 13, 83, 111, 146, 155, 197,212

Buchanan, W.D. 76

Buck, H.D. 203

Bucke, D. 13, 70, 83, 111, 146, 190, 212

Buehler, K. 83

Buhler, D.R. 160

Buikema, A.L. 14, 50, 140, 226

Buikema, A.L., Jr. 14, 70, 84, 99 , $105,111,146,160,180,190,197$; 212

Bulicek, J. 190

Bulow, F.J. 38, 42, 64, 65

Bulthuis, D. 14

Bumbu, Y.V. 14

Burbank, N.C. 192

Burdick; G.E. 128

Burkett, R.D. 161

Burkhalter, D.E. 70

Burks, S.L. 37, 121, 151, 220 
AUTHOR INDEX (Contd.)

Burr, J.G. 136

Burrows, R.E. 71

Burrows, W.D. 68,161

Burton, D.T. 212, 219

Butler, R.L. $1.4,59$

Button, D.K. 14,77, 112

Byerrum, R.U. 8, 19, 35, 82, 85, 90, $98,100,102$

Cairns, J., Jr. 14, 15, 41, 44, 48, $50,65,66,69,70,73,84,96$, $99,100,103,105,106,111,112$, $123,128,137,138,146,151,157$, $160,180,184,188,190,193,197$, $203,212,213,219,220,222,224$, 227

Calabrese, A. 15, 68, 84, 100, 112, $135,155,161,180,184,197,198$, 213

Calamari, D. 15, 71, 112

Cambe11, R.S. 12, 59

Cameron, I.L. 16, 84, 105, 146, 161, 213

Campbel1, H.J. 203

Campbell, R.S. 15, 26, 33, 59, 62, 63,67

Canton, S. 54

Cardwell, R.D. 15, 194

Carpenter, K.E. 15, 16, 146

Carpenter, R. $11,160,203$

Carriker, N.E. $16,77,80$

Carson, W.G. 16, 56, 57, 60, 66, 95, $112,127,141,207,213,227,228$

Carson, W.V. $16,56,60,66,112$, $127,207,213,227$

Carter, J.A. 27

Carter, J.W. 16, 84, 105, 146, 161, 213

Cearley, J.E. 16, 84, 100, 197

Cedenoma, A. 112

Chai semartin, C. 100

Chakrabarti, P.C. 47, 67, 74, 134, $188,202,206$

Chan, L:K. 115

Chang, S.B. 170

Chapman, G. 16, 60,66, 84, 112, $138,147,184,213$

Chappe11, W.R. 179

Charnot, A. 131, 136, 138

Chen, C.W. 16
Chen, K.Y. 201

Cheng, J.Y. 80

Cheng, T.C. 50, 112

Cheremisinoff, P. $16,84,100,147$, 161

Chi, L. 56

Childs, E.A. 161

Chipman, W.A. 184, 213

Chow, T.J. 1.47

Christensen, G.M. $10,16,79,82$, $84,109,112,119,141,147,159$, $161,180,197,201,210$

Christie, A.E. 30,63

Clarke, G.T.C. 211

Clarke, R. McV. 3, 16, 17

Claugh, G.W. 128

Clel and, K.W. 17

Clemens, H.P. 131

Clubb, R.W. 84

Cole, A.E. 17, 71, 147, 190

Cole, L.J. 37, 120, 220

Cole, S.L. 190

Coleman, R.D. 17, 105, 213

Coleman, R.L. 17, 84, 105, 197, 213

Coles, J. 157

Collett, M.E. 60

Collier, R.S. $51,85,94,126,198$

Colmano, G. 179

Colmer, A.R. 17

Colt, J. 71

Colwe11, R.R. 161, 172, 177

Comodo, N. 25, 165, 191, 194

Conner, P.M. 17, 112, 161, 214

Cook, R.H. 17, 60, 112, 113, 138, 214

Cooke, W.B. 17, 60

Cooley, H.L. 119

Coombs, T.L. 17, 87, 113, 214

Cooper, A.T. 119,129

Cooper, E.L. 17, 60

Cooper, V.A. $19,85,113,138,214$

Copeland, R. 195

Copenhaver, E.D. 3, 77, 85

Corbet, A.B. 180

Cordone, A.J. 179, 204

Corner, E.D.S. 18, 113, 162

Cornet, D. 113

Cornick, J.W. 137

Cossa, D. 85

Costa, H.H. 18, 128, 199

Costlow, J.D., Jr. 92, 134 
AUTHOR INDEX (Contd.)

Cote, R.P. 17, 18,60, 112, 138, 214 Coughtrey, P.J. 18, 85, 113, 147 , 214

Courtois, L.A. 113

Cowel1, B.C. 18, 77, 197

Cox, D.P. 77

Cox, M.F. 166

Craig, G.R. 60

Craig, S. 18

Cram, P. 91

Crance, J.H. 113

Crandal 1, C.A. 18, 147, 214

Creaser, C.W. 184

Cross, F.A. 18, 141, 155, 214

Cross, F.B. $48,66,96,188$

Crum, B. 157

Cumming, K.B. 155, 204

Curtis, E.H. 162

Curtis, W.R. 204

Cushman, R.M. 27

Czapowskyj, M.M. 3, 18

Czensky, R. 60,128

Czyrska, H. 29,88, 117, 181, 198, 217

D'Agostino, A. $18,85,113$

D'Amelio, V. 18

D'Itri, F.M. 162

Dabrowski, K.R. 77

Dah1, J. 19, 141, 203

Dalton, R.A. $12,111,180,190,211$

Dams, R. 19

Daniel, J.W. 162

Daniels, R.R. 113, 142

Daugherty, A.M. 184

Davenport, J. 113, 131

Davies, A. 162

Davies, P.H. 19, 85, 131, 138, 140, 147,223

Davis, E.L. 29, 77, 117,139

Davis, G.J. 133

Davis, H.C. 184, 204

Dawson, A.B. 147

Dawson, M.A. $51,94,126,135,198$

Daye, P.G. $60,66,184$

Dayton, L. 147

De Calventi, I.B. 113

De L.G. Solbe, J.F. 19, 71, 85, 113, $138,190,214$

Dean, J.M. 214
Decker, C: 19

Decker, C.F. $19,68,85,100,142$

DeCoursey, D.J. 162

Delhaye, W. 113

DeMann, J.G. 53, 81, 105, 153

deRoos, C.D. 136

Deschiens, R. 215

Dettman, E.H. 19, 39

Dhar, S.K. 19

Dickson, K.L. 14, 112, 213

Dieh1, W.T. 20, 60

Dietz, F. 20

Dilling, w.J. 20,80, 114, 148, 207 , 215

Dimitroff, J.M. 86

Dively, J.L. 61

Dorfman, D. 148

Dorn, P. 162

Doudoroff, M. 73

Doudor off , P. 3, 20,61, 114, 128 , $180,184,197,204$

Dowden, B.F. 20,132

Down, C.G. 20

Downa, W.L. 4, 137

Downing, K.M. 71,128

Downs, W.L. 207

Drucker, H. 20

Drummond, R.A. 114, 162, 184

Drury, D.E. 48

Dugger, W.M. 116

Dulka, J.J. 20

Dunker, S.S. 14, 77, 112

Dunson, W.A. 52, 61, 185, 187

Dvorak, A.J. 20

Dyk; V. 61,185

Easterday, R.L. 179

Eaton, J.G. 21, 85, 86, 114, 215

Ebeling, G. 21, 142

Eckenfelder, W.W. 68,188

Edminster, J.0. 21, 61,.97

Effenberger, M. 191

Egan, A.R. 38

Eisler, R. 3, $21,86,100,114,148$, $155,163,181,215,218$

E1der, J.F. 142

Elis, D.V. 30

E11is, M.M. 195, 204

Elmaraghy, M.A. 74

Elson, P.F. 49, 124, 225 
AUTHOR INDEX (Contd.)

E1wood, J.W. 21

E1y, R.B. 163

Emerson, K. 21, 71, 185

Emigh, W.C. 185

Enk, M.D. 22, 86, 148

Epifanio, C.C. 71

Eppley, R.W. 116

Erdman, H.E. 88, 95, 139, 154

Erichsen, L.V. 22

Erickson, S.J. 114

Eriksson, C. 163

Establier, R. 22, 114, 142, 155, 215

European Inland Fisheries Advisory Commission $71,86,185,190,204$, 215

Evans, B. $52,126,144,153,182$, 226

Everhart., W.H. $67,69,147,185$

Everson, W.A. 46;66

Eyman, L.D.: 21

Fagerstrom, T. 163

Fairchild, E.J. 100,132

Falk, D.L. 61; 185

Falk, M.R. 22

Farran, M. 221

Farre11, M.P. 127

Faubin, H.E. 136

Faust, S.L. 115

Fawe11, J.K. 131, 190

Federation of Sewage and Industrial Wastes Associations 22, 100, 114 , 163,215

Fedkenheuer, P.J. 22, 148

Fenwick, M.G. 166

Ferens, M.C. 163

Ferguson, J.F. 164

Fielding, A.H. 114

Filice, F.P. 181

Filip, D.S. 163

Fingal, W. 114

Finger, J.H. 178

Fingerman, M. 165

Finnel1, J.C. 131

Finney, C. 18, 85, 113

Fisher, A. 114

Fisheries Research Board of Canada 163

Fitzgerald, G.P. 22, 71, 114, 115

Fiussello, N. 148

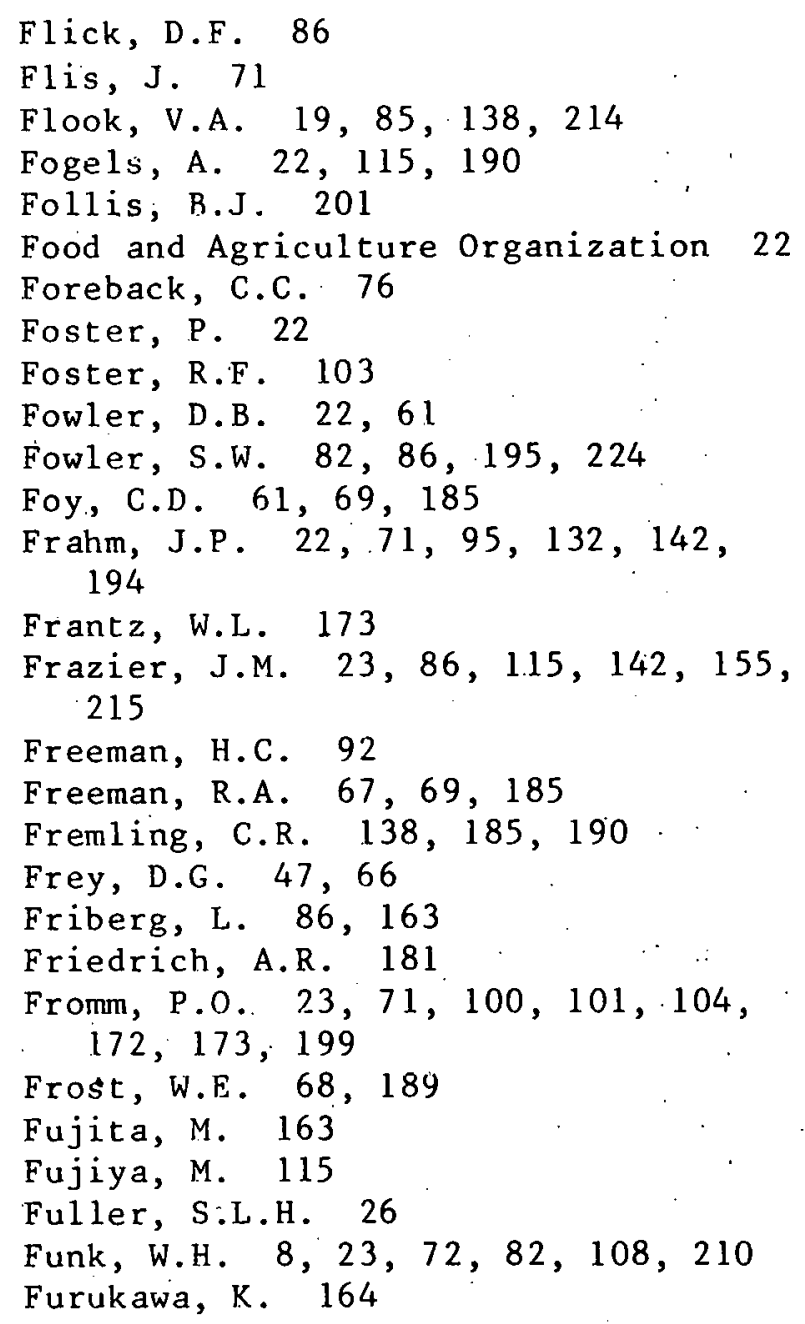

Gabrovski, K. 46, 179

Gaechter, R. 23, 86, 115, 148, 164 , - 215

Gaggino, G.F. 173

Gale, N.L. 23, 148, 149

Gamble, J.C. 122

Gammon, J.R. 204

Ganther, H.E. 24, 164, 195

Gardner, G.R. 21, 24, 86, 87, 114 , $115,164,197,215,216$

Gardner, W. 164

Garrey, W.C. 132

Garrison, P.J. 54

Garside, E.T. $60,66,184$

Garton, R.R. 24, 101

Gasper, D.C. 24

Gast, M. 111

Gast, M.H. 91 


\section{AUTHOR INDEX (Contd.)}

Gatz, M. 164

Gaufin, A.R. 50,84

Gavis, J. 164

Geckler, J.R. 111, 115

Gehrs, C.W. 104

Geldiay, R. 24

George, J.R. 9

George, S.C. 87

Gerloff, G.C. $61,69,185$

German, M.J. 61

Gersdorff, W.A. 191

Giblin, F.J. 164

Gibson, C.E. 115

Gibson, C.I. 115

Gibson, V.R. 115

Giesy, J.P. 87

Giesy, J.P., Jr. 24

Gilderhus, P.A. 77

Gillespie, D.C. 164, 201

Gillespie, W.T. $16,77,80$

Gillette, L.A. 24

Glass, G.E. $105,108,131,157$

Gleason, V.E. 3,11, 24, 59, 183

Glenn-Lewin, D.C. 3, 24

Glickman, A.H. 191

Glooschenko, W.A. 164

Gloyna, E.F. 170

Goering, J.J. 116

Goettl, J.P., Jr. 19, 140, 220, 223

Goldman, C.R. 117

Goldstein, R.A. 166

Goncharov, G.D. 191

Gooding, D. 24

Goodman, J.R. 216

Goodnight, C.J. 18, 147, 214

Goodyear, C.P. 28,62, 67, 142, 185 , 200,202

Gosner, K.L. 61

Gothberg, A. 165

Gough, L.P. 25

Graham, D.W. 101

Grande, M. 25, 116, 216

Gray, J.S. 25, 149, 164, 216

Gray, J.W. $21,61,97$

Great Lakes Laboratory 4, 25, 77, $87,101,164,195$

Green, G.H. 81

Green, R.H. 175

Green, W. 165

Greene, J.C. 216

Greenfield, J.P. 142, 204
Greenshields, J. 25, 61

Greer, W.C. 54, 70,81, 137, 207

Gregory, R.W. 54

Greichus, Y.A. 25

Greve, W. 176

Grice, G.D. 62, 115

Griffin, L.E. 204

Griffith, N.A. 28, 166, 195

Griffiths, W. 118

Grindley, J. 25, 77, 101

Gross, R.E. 116

Groth, E., III. 136

Gruendling, G.K. 151

Grushkin, B. 46, 124

Guarino, A.M. 165

Guerin-Ancey, 0.72

Guerra, M. 25, 165, 191, 194

Guillard, R.L. 125

Gusseva, K.A. 155

Gutenmen, W.H. 158

Guthrie, T.F. 222

Gutnecht, J. 216

Haberer, K. 25

Habib, Y. $16,84,100,147,161$

Hahn, H.H. 204

Hahne, H.C. 25, 87, 97, 149, 165, 185,216

Haider, G. 149

Hakanson, D.E. $42,122,143,187$, 221

Hale, J.G. 25,198

Hales, D.C. $63,67,186$

Hall, E.P. 26

Hamdy, M.K. 165,173

Hamelink, J.L. $36,69,90,171$

Hamilt on, A.L. $8,98,108,141,145$, 155,209

Hamlin, J.M. 29,149

Hampson, B.L. 72

Hann, R.W., Jr. 30

Hannan, P.J. 26, 87, 116, 149, 165, 198

Hannerz, L. 165

Hara, T.J. 26, 116, 165

Hardisty, M.W. 26

Hargis, J.R. 185

Hargreaves, J.W. 26, 95, 116, 185 , 216

Harkawa, C. 203 
AUTHOR INDEX (Contd.)

Harp, G.L. 26, 62

Harrel, R.C. $40,102,121,133,172$

Harrison, A.D. 26,62

Harrison, E.A. 4, 26

Harrison, S.E. 116

Harrison, W.G. 116

Harriss, R.C. 133, 165, 169

Harry, H.W. 57

Hart, C.W., Jr. 26

Hart, O.H. 205

Harvey, H.H. 59, 62

Harvey, R.S. 26, 199, 216

Hasfurther, W.A. 102

Hashizume, K. 163

Hasler, A. 191

Hassall, K.A. 116

Hasselrot, T.B. 165

Hattingh, J. 72

Hattori, A. 116

Haupt, H. 62

Havelka, J. 191

Hawley, J.R. 26

Haze 1, C.R. 116

Healey, C.W. 20,80,114, 148, 207, 215

Heath, A:G. 45, 124, 223, 224

Heisinger, J.F. 165

Heit, M. 26, 165

Hellman, H. 26, 204

Helz, G.R. 27, 87, 116, 142, 149, 156,216

Hem, J : D . $27,142,156$

Hemens, J. 136

Hemphi.11, D.D. 27

Henderson, C. $41,51,76,80,92$, $103,122,128,152,179,181,208$, 221

Henley, D.E. 78

Henly, J.P. 27,62

Hennekey, R.J. 21,86, 100, 163, 215

Henry, J.A.C. 89,139

Herbert, D.M. 70

Herbert, D.W.M. 27, 34, 72, 73, 116 , $129,132,136,191,205,216,217$

Hermann, E.R. 27, 101

Hernandez, T. 89

Herricks, E.E. 27, 62

Hervey, J.R. 101

Hessler, A. 149

Hiatt, V. 87

Hildebrand, S.G. 21, 27
Hil1, C.H. 117

Hi11, D. 28,62

Hil1, D.M. 28, 155, 156, 185, 204

Hil1, J.M. $27,87,116,142,149$, 156,216

Hill, R.A. 28

Hiltibran, R.C. $28,87,95,156,217$

Hine, C.H. $56,79,153,177,196$

Hinkle, M.E. 17

Hirshfield, H.I. 83

Hoagl and, E. 62

Hodgson, E.S. 132

Hodson, P.V. 217

Hoehn, R.C. ' 28, 62, 205

Hoffer, K. 69

Holcombe, G.W. 149

Holden, A.V. 166

Holderness, J.: 166

Holl and, G.D. 28

Holm, H.W. 166

Hoos, R.A.W. 17, 113, 138, 214

Hopkins, R. 28

Hoppert, C.A. $8,19,35,82,85,90$, $98,100,102$

Horne, A. 117

Horne, A.J. 142

Hoskins, K.D. 108

Hoss, D.E. 217

Houston, A.H. $89,132,139$

Howard, A.G. 28

Hublou, W.F. 28, 87, 217

Hubschman, J.H. 117

Huckabee; J.W. $28,62,67,88,142$, $166,185,195,200,202$

Hudson, K.M. 166

Hueck, H.J. 117

Huff, J.E. 87

Huggett, R.J. 27, 87, 116, 142, 149, 156,216

Hughes, J.S. 29

Hulth, L. 168

Hummerstone, L.G. 13,83, 111, 155, 212

Hummon, W.D. 64

Hunt, E.P. 119

Hunter, W.R. 29, 117, 166

Hutchinson, G.F. 154

Hutchinson, T.C. $29,49,79,88$, $106,117,149,166,181,195,198$, 217 
AUTHOR INDEX (Contd.)

Imlav, M.J. 194

Imura, N. 166

Inglis, A. $29,77,117,139$

Ingols, R.S. 101

Irel and, M.P. 142, 204, 217

Ishak, M.M. 117

Ishio, S. 29

Ito, T. 72

Iverson, R.L. 133

Iwao, T. 29, 156

Iwas aki, K. 163

Ja, E.C. 134

Jackim, E. $29,88,117,149,198$, 217

Janssen, R.G. 186

Jarvenpaa, T. 91,166

Jeffries, E.R. 28, 87, 217

Jenkins, C.R. 65

Jenkins, D.W. $30,75,77,88,101$, $106,117,150,167,181,208,217$

Jenne, E.A. $30,106,117,142,156$, $167,181,217$

Jensen, A. 11, 110, 154, 211, 217

Jensen, P.A. 30

Jensen, S. 167

Jernelov, A. 89, 163, 167

Jewe 1, M.E. 62

Jewe 11, M.E. 95

Johansson, N. 63,64, 186

Johnels, A.G. 167

Johnson, D.W. 63

Johnson, M.G. 30,63

Johnșon, W.W. 72

Jonas, R.E.E. $10,82,109$

Jones, A.A. 30

Jones, A.H. 212

Jones, A.K. 35

Jones, G.E. 180

Jones, J.R.E. 30, 79, 95, 98, 101 ,

$118,150,156,167,191,199,218$

Jones, L.H. 118

Jones, M.B. $31,132,167$

Jones, N.V. 118

Jones, R.D. 28, 62, 67, 142, 185, 200,202

Jones, W.H. 131

Jordan, D.H.M. 13, 64, 70, 137, 190, 212

Joseph, J.M. 31,63
Joyce, J.C. 56

Joyner, T. 218

Jude, D.J. $31,72,88$

Just, J.J. $10,83,146,159,210$

Kaemmerer, K. 22

Kain, J.M. 28

Kalabina, N.M. 31,150

Kalk, M. 208

Kamp-Nielsen, L. 125

Kania, H.J. 167, 168, 175

Kapkov, V.I. 118

Kapkov, V.T. 118

Kaplan, H.M. 114,118

Kaplan, I.R. 183

Kapoor, M.N. 118

Karbe, L. 31

Karpevich, A.F. 132, 156

Karsten, A. 129

Kato, T. 31

Katz, M. 3, 20, 31, 63

Kawatski, J.A. 139,191

Kaya, C.M. 70

Keckes, S. 132,168

Keeney, D.R. ' 4, 72, 132, 186

Keller, E.C. 193

Keller, E.C., Jr. 141, 200

Kelley, D.W. 204, 205

Kelley, W.H. 34

Kemp, H.T. 31

Kempf, C. 168

Kendall, M.W. 168

Kerfoot, W.B. $31,88,102,118,150$, 181

Ketch am, B.H. 32

Kevern, N.R. 36, 90, 119, 151, 170, 207

Khobot'ev, V.G. 118

Kihlstrom, J.E. 168,186

Kim, J.H. 32, 168, 195

Kimbal1, K.D. 118

Kimme1, W.G. $63,67,186$

Kinkade, M.L. 88, 95, 139, 154

Kinnison, R.R. 150

Kirkpatrick, E.S. 101

Kiry, P. 45, 69, 93, 104, 124, 143, $152,154,157,175,182,223$

Klass, E: 88

Klassen, C.W. 102

Klaunig, J. 168 
AUTHOR INDEX (Contd.)

Kleerekoper, H. 98, 118, 132

Klute, R. 204

Knauer, G.A. $11,32,76,83,89,99$, $105,109,118,141,146,150,155$, $156,168,210,218$

Kneip, T.J. 89

Knepp, G.L. 73

Knight, R.L. 167,168

Kobayashi, K. 191

Koelling, J.J. 32, 67, 76, 102, 106, $143,168,186,218$

Koenst, W.M. 129

Koepp, S. 168

Ko1b, L.P. 168

Koli, A.K. 169

Kopp, J .F . 32, 102

Kopperman, J.L. 191

Korsak, M.N. 37, 90, 102, 220

Koryak, M. 32, 63

Kostiuk, S.J.M. 22

Kostyaev, V. Ya. 192

Krauter, K. 49.

Kraybill, H.F. 86

Krenke 1, P.A. 32, 161

Krishna, D. 186

Krist of ferson, R.

192

Krombach, H. 192

Kroner, R.C. 32, 102

Kronfield, J. 32

Kroont je, w. $25,87,97,149,165$, 185,216

Krzyz, R.M.:44, 123, 143, 151, 223

Kubena, M. 156

Kudo, A. 169

Kuenzler, E.J . 32, 106, 143, 218

Kuhn, R. 12, 75, 99, 110, 136, 178, 194

Kumad a, H. 89

Kumar, H.D. 195

Kurihara, I. 73, 202

Kushner, D.J. 42, 173

Kustin, K. 208

Kuznetsova, K.A. 218

Kwain, W. 63

Lackey, J.B. 33, 63, 205

Ladd, K.V. 208

LaHam, Q.N. 196

Lake, P.S. 51, 89, 94, 226

Lakin, H.W. 195
Lammering, M.W. 192

Lande, E. 33

Landner, L. 89

Lanford, C.E. 33

Langley, D.G.' 169

Langlois, T.H. 205

Lansford, C.M. 120

Lansing, A.I. 33, 96, 133, 186

LaRiviere, M.G. 4, 33

LaRoche, G. 115

LaRoze, A. 143

Larson, R. 41

Larsson, A. 89

Lasater, R. 54,70,81, 137, 207

LaSher, M.F. 4, 137

Lask, D.J. 169

Laumond, F. 169

Lawrence, A.W. $33,160,169,183$, 218

Lawrence, J.M. 77

Lebedeva, G.D. 218

Leclerc, E. 80

Leduc, G. 129

Lee, D.R. 14, 70,99, 190

Lee, Y.L. 33

Lehmann, C. 129

Leivestad, H. 63,186

Le 1 and, H.V. 33, 46, 150, 152

Lelt, P.F. 118

Leonard, E.N. 108, 111

Leonard, J. 42, 65

Lepple, F.K. 169

Lewin, R.A. $147,152,154$

Lewis, A.G. 33, 119, 205

Lewis, E. 176

Lewis, M. 157

Lewis, S.D. 33, 119,218

Lewis, W.M. 33, 119, 143, 218

Liden, L.H. 33

Lind, D.T. 129

Lind, 0.T. 33, 63, 67

Lindberg, S.E. 169,176

Lingerg, S.E. 169

Lipschuetz, M. $119,128,129$

Lisk, D.J. $57,127,158,198$

Little, A.D., Inc. 34

Lloyd, B.J. 44, 152, 175, 223

Lloyd, R. $34,63,64,67,73,119$, 186,219

Lock, R.A.C. 169

Lockhart, W.L. 169 
AUTHOR INDEX (Contd.)

Lockwood, A.P.M. 34

Loeb, H.A. 34

Loew, O. 200

Lofroth, G. 158

Lords, J.L. 84

Lorz, H.W. 34, 119, 219

Loutit, M.W. 33, 34, 40, 41, 103, $121,143,151,157,220$

Lovett, R.J. 173

Lu, P. $34,89,119,150,219$

Lubinski, K.S. 34

Lucis, 0.J. 45, 93, 223

Ludemann, D. 157

Luduc, G. $20,61,128,180,184,197$

Lues chow, L.A. 77

Luh, M.D. 78

Lum-Shue-Chan, K. 115

Lundberg, C. 168

Lunde, G. 78

Lundgren, D.G. 34

Luoma, S.N. 33, 35, 169, 170

Lutz, A. 175

Lynch, D.L. 166

Lynn, R.I. 163

Macf adyen, W.A. 200, 201

MacFarlane, R.B. 165

MacInnes, J.R. 35, 90

Mackenthun, K.M. 119

Mackenzie, R.D. $35,90,102$

Mackereth, F.J. 119

MacLeod, J.C. 170

MacPhee, C. 35

Mahd i, M.A. 64,67, 186

Maine Department of Environmental

Protection $67,120,139$

Major, C.W. 124

Majori, L. $35,90,120,151,170$

Malacea, I. $36,73,78,129,170$

Malanchuk, J.L. 151

Malaney, G.W. 36

Malins, D.C. 53, 153, 177

Maloney, T.E. 36, 120

Maloseja, Z. 192

Malthus, R.S.. 34

Mandel1i, E.F. 120

Mang, S. 90

Marcellus, P. 23, 148

Marchetti, R. 15, 71, 112, 173
Marinescu, A.G. 192

Marking, L.L. $139,186,192$

Martin, J.H. $32,36,89,118,150$, $156,1,68,218$

Martin, M.H. $18,85,113,147 ; 214$

Martin, R. 61

Marvin, K.T. 120

Massaro, E.J. 88,164

Matej, V.E. 192

Mathis, B.J. 22, 36, 86, 90, 148, $151,1.70,207$

Matida, Y. 170

Matis, J. 118

Matrone, G. 117

Matson, R.S. 170

Matsui, S. 170

Mattey, D.L. 91

Matthiessen, P. 96, 211, 219

Mayer, A.M. 159

Mayer, F.L. 36, 69, 90, 171

Maynard, E.A. 4, 137

McBride, B.C. 78

McCarty, L.S. 89,139

McCashland, B. 129

McCormick, M. 168

McFeters, G. 39

McGahee, C.F. 133

McIntosh , A. 35, 90, 102, 150, 219

McIntosh, A.W. 119

McIntyre, A.D. 35

Mckee, J.E. 35

Mckeown, B.A. 227

McKim, J.M. 35, 111, 119, 133, 170, 186

McKone, C.E. 170

McLean, R.0. 35, 219

McLease, D.W. 120, 133

McLeod, G.C. 208

McLoughlin, T.F. 76

McLusky, D.S. 120

McNamara, W. $40,91,181$

McNurney, J.M. 150

McPherson, B.P. 34, 119; 219

McRoy, C.P. 131.

Mechan, O.L. 79

Meisch, H.U. 208

Meith; S.J. 116

Mellinger, P.J. 171

Melsom, S. 217

Menasvet a, P. 171

Menendez, R. 19,64, 68, 142, 187 
AUTHOR INDEX (Contd.)

Merkens, J.C. 71, 129, 205

Merlini, M. 36, 151, 171, 187, 219

Meyer, D.K. 171

Meyers, S.P. 36

Michalski, M.F.P. $30 ; 63$

Middaugh, D.P. 90

Mierle, G. 36, 64, 96, 1.71, 187

Miettinen, J.K. $132,166,168$

Miettinen, V. 171

Mikryakov; V.R. 191

Milbrink, G. 63, 64

Miller, D.L. 24, 192

Miller, M.D. 22, 49, 152, 225

Miller, R.F. 179

Mills, C.F. 35

Mills, W.L. $36,90,120,171,219$

Minkina, A.L. $37,69,143$

Minogue, J.E. 55

Mitrovic, V.V. 139, 192, 211

Mohamed, A.M. 117

Mohus, A. 11, 110,154, 211

Mokryak, A.S. 14

Molinari, V. 215

Monk, J.T., Jr. 56

Monroe, G.B. 37

Montiel, A. 208

Moore, D. 183

Moran, R.E. 37

Moravcdva, V. 192

Morgan, E.L. 33, 212, 219

Morgan, G.B. 205

Morgan, J.J. 157

Morgan, R. 158

Morgan, R.P., II. 37, 90, 102, 120 ,

$143,171,219$

Mori, T. 223

Morris, A.W. 37

Morris, J:C. 201

Morris, O.P. 120,123

Morxy, C.J. 37, 120, 220

Mortimer, D.C. 163

Moulton, E.Q. 37,64

Mount, D.I. $64,67,120,121,139$, $171,187,220,227$

Mudge, J.E. 187

Muniz,.I.P. 63,186

Munjko, I. 192

Murdock, H.R. 37, 102, 172

Murphy, T.P. 143

Mustoe, G.E. 170

Myers, D.J. 78
Myers, V.R. 133

Nakagawa, II. 29

Nakahara, M. 106

Nakani, D.v. 37, 90, 102, 220

Nakatani, R.E. 220

Namminga, H.E. 37, 121, 151, 220

Nash; H.D. 55

Nat arajan, K.V. 73

National Academy of Science and National Academy of Engineering 37

National Academy of Sciences 172

National Coal Association and

Bituminous Coal Research, Inc. 37

National Research Council 121

Natural Resource Ecology Laboratory $4,37,38$

Natusch, D.F.S. 38

Navrot, J. 32

Neary, B.P. 160

Nebeker, A.V. 59,183

Neel, J.K. 67, 73, 96, 1.33, 139, 154

Neff, A. 137

Negilski, D.S. 38, 90, 102, 220 .

Nehring, R.B. 38, 220

Neil, J.H. 129

Neilson, A.H. 73

Nelson, D.A. 15, 38, 78, 91, 172, 198

Ne1son, J.D. 161

Nelson, J.D., Jr. 172

Nelson, J.J. 195

Nerrie, B. . 43, 122, 181, 222

Neuhold, J.M. 136, 137

Newel1, R.C. 12, 110, 211

Newman, J.P., Jr. 38

Nicholos, D.J.D. 38

Nichols, L.E. 38,64

Nicola, S.J. 179

Nicolle, P. 131, 159

Nielson, S.S. 38, 121, 143

Niimi, A.J. 196

Nilsson, R. 91

Nishikawa, K. $38,106,121,199$

Nomi y ama, K. 39,172

Nordberg, G.F. 86, 163

Noren, K. 172

Normann, S. 25 
AUTHOR INDEX (Contd.)

Nowak, S.H. 175

Nusch, E.A. 39

Nuzzi, R. 172

O'Connor, D.V. 172

O'Halloran, M.J. 92

0'Hara, J. 91, 121, 133, 135, 177

O'Rear, C.W., Jr. $40,121,220$

Office of Water Research and

Technology 4, 5, 39, 64, 172

Office of Water Resources Research 4, 102

Ogden, R.D. 48

Ogilvie, D.M. 192

Ohada, Y. 57, 97, 200, 203

Ohio River Valley. Water Sanitation Commission 42

Oikari, A. 192

Okanen, H.E. 196

Okazaki, R.K. 121

Olafsen, J. 123

Oliff, W.D. 136

Olsen, R.D. $19,39,45$

Olson, G. 39

Olson, G.F. $114,162,172,184$

Olson, K.R. $40,102,121,133,172$, 173

O1son, L.E. $139,186,192$

Olson, P.A. 103

Olsson, M. 173

Orciari, R.D. 64

Oregioni, B. 82

Orr, L.D. 73

Oseid, D.M. 202

Oshida, P.S. 103

Overnel1, J. $40,91,121,173,220$

Overrein, L.N. 64

Owens, M. 200

Pace, E. 129

Pacific Northwest Symposium 52

Packer, R.K. 187

Paffenhofer, G.-A. 205

Pagenkopf, G.K. 40, 67, 121, 133, 187

Palmer, M. 36, 120

Pan, S.K. 166

Parizek, J. 40, 91, 173, 196

Parks, G.A. 173
Parletic, Z. 192

Parsons, J.D. 40,64,65

Parsons, J.W. 5, 40,65

Paschal, D.C. $40,91,181$

Pascoe, D. 91

Pascual, E. 22, 114, 142, 155, 215

Patouillet, C. $26,87,116,149$, 165,198

Patrick, F.M. 33, 34, 40, 41, 103, $121,143,151,157,220$

Patrick, R. 26, 41, 73, 157, 199, 216,220

Pavicic, J. 91

Peaka11, D.B. 173

Pearson, J.E. 174

Peden, J.D. 41

Pegg, W.J. 65

Penaz, M. 74

Pennacchioni, A. 173

Penrose, W.R. 78

Pentreath, R.J. 41, 106, 143, 157 , $173,220,221$

Perlmutter, A. 43, 123, 174, 222

Perrin, D.D. 41

Persoone, G. 41

Pesonen, L. 196

Pessah, E. 170

Peters, J.C. 205

Petersen, K.K. 179

Peterson, J.R. 179

Peterson, L.A. 113, 142

Petronio, F. 35, 90, 120, 151, 170

Pfeifer, E. 154

Phelps, R.V. 222

Phillips, A.M., Jr. 65, 122, 133

Phillips, C.N.K. 120

Phillips, D.J.H. 41, 91, 122, 134 , 151,221

Phinney, H.K. 205

Pickering, Q.H. 41, 91, 92, 103, $122,181,221$

Pilson, M.E.Q. 109

Pipes, W.0. 104

Piscator, M. 86

Pittwe11, L.R. 42

Pollard, C.B. 134, 139

Pomela, C.S. 80

Poon, C.P.C. 42, 103, 122, 181, 198, 221

Popovic, M. 12, 66, 83, 99, 110, $137,160,179,180,211$ 
AUTHOR INDEX (Contd.)

Porter, K.R. 42, 122, 143, 187, 221

Powers, E.B. $134,187$.

Pozzi, G. 151,187

Prabhu, N.V. 173

Prakash, G. 195

Perlmutter, A. $43,123,174,222$

Perrin, D.D. 41

Persoone, G. 41

Pesonen, L. 196

Pessah, E. 17.0

Peters, J.C. 205

Petersen, K.K. 179

Peterson, J.R. 179

Peterson, L.A. 113,142

Petronio, F. 35, 90, 120, 151, 170

Pfeifer, E. 154

Phelps, R.V. 222

Phillips, A.M., Jr. 65, 122, 133

Phillips, C.N.K. 120

Phillips, D.J.H. 41, 91, 122, 134 , 151,221

Phinney, H.K. 205

Pickering, Q.H. 41, 91, 92, 103, $122,181,221$

Pilson, M.E.Q. 109

Pipes, W.O. 104

Piscator, M. 86

Pittwe 11, L.R. 42

Pollard, C.B. 134, 139

Pomela, C.S. 80

Poon, C.P.C. 42, 103, 122, 181, 198, 221

Popovic, M. 12,$66 ; 83,99,110$, $137,160,179,180,211$

Porter, K.R. 42, 122, 143, 187, 221

Powers, E.B. 134, 187

Pozzi, G. 151,187

Prabhu, N.V. 173

Prakash, G. 195

Prescott, L.M. 42

Presley, B.J. 47

Preston, E.M. 103

Price, T.J. 213

Priddy, A.H: 174

Pringle, B.H. 42,46

Pugno, P. 116

Pulley, T.E. 69

Quillen, R. 36

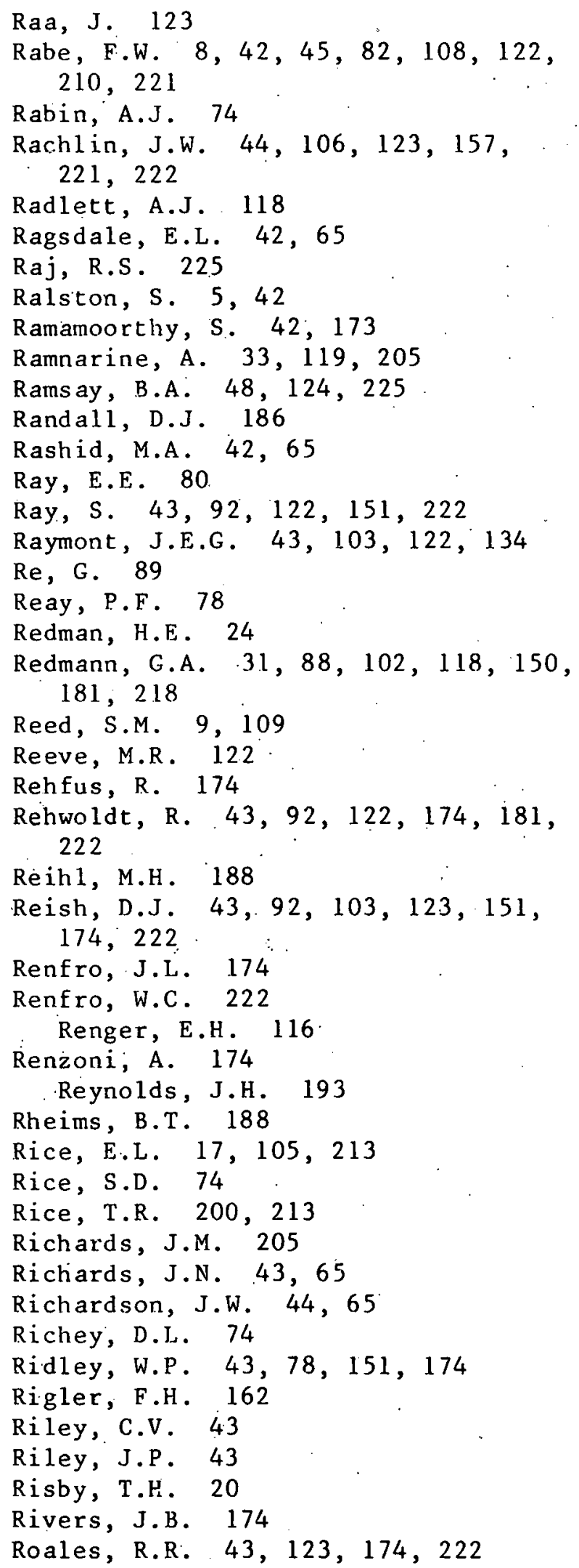




\section{AUTHOR INDEX (Contd.)}

Koback, S.S. 44, 65

RobertB, B.A. 134

Roberts, O.W. 10

Robertson, M. 206

Robinette, H.R. 74

Robinson, G.D. 65,188

Robinson, M.C. 160

Robinson, S. 5, 174

Robisch, P.A. 53, 153, 177

Rods aether, M.C. 123

Roesijadi, G. 98, 174

Romeril, M.G. 11, 222

Rosco, J.J. 44, 106, 123, 157, 222

Roseboom, D.p. 74

Rosen, C. - G. 158

Rosenberg, R. 92,134

Rosenfeld, I. 196

Rosenthal, H. 94, 135

Roth, I. 43

Rothstein, A. 44

Rowe, D.W. 88

Royer, L.M. 177

Ruby, S.M. 65

Rucker, R.R. 174

Rudolfs, W. 5, 44

Ruelle, R. 35

Ruesink, R.G. 44, 103

Rukhadze, E.G. 118

Russe11, G. 114, 120, 123

Russel1, H.H. 3, 24

Russo, R.C. $40,51,52,67,121$, 133,187

Ruthven, J.A. 44, 65, 69, 103, 106, $123,151,157,193,222$

Rutschky, C.W., III. 55

Rystad, B. 217

Rżewuska, E. 44, 174

Sabodash, V.M. 223

Saiki, M. 223

Sakur ayama, H. 65,196

Saliba, L.J. 44, 123, 143, 151, 223

Salzinger, K. 44, 69, 92, 96, 106 , $139,151,154,157,175,194,200$, 223

Sanborn, N.H. 44, 69

Sanders, H.O. 72

Sandholm, M. 196

Sand ifer, P.A. 175

Sangalang, G.B. 92
Sano, H. 188

Sappington, C.W. 221, 223

Sartory, D.P. 44, 152, 175, 223

Saunders, J.W. 134

Saunders, R.L. 44, 49, 123, 124 , 223,225

S aunders, W. 167

Saurent, P. 103

Saurov, M.M. 200

Sauter, S. 45, 92, 104, 123, 152

Savage, N.L. 45

Savannah River Ecology Laboratory 45

Saward, D. 32,123

Sayce, I.G. 41

Sayrs, R.L., Jr. 92

Schaefer, E.D. 104

Scheier, A. 14, 15, 41, 45, 69, 73, $93,99,100,104,124,128,137$, $138,143,152,154,157,175,182$, 213,223

Scherer, E. 175

Scheuring, L. 134, 199, 201

Schiffman, R.H. 101, 104

Schindler, J.E. 45, 93, 104,175

Schmidt-Nielsen, B. $45,134^{\circ}$

Schmitt, J.B. $65^{\circ}$

Schneider, C.R. $20,61,128,180$, 184,197

Schneider, R.F. 45

Schofield, C.L. 66

Schott, W. 223

Schrift, A. 196, 203

Schubert, J.P. 45

Schulz-Baldes, M. 152

Schwarz, K. 196

Schweiger, G. 45

Scott, D.P. $164,175,201$

Scott, J.E. 37, 121, 151, 220

Scott, W.B. 5, 174

Seibert, D.L.K. 126

Seifriz, W. 45, 134

Selesi, D. 74

Sellers, C.M. 45, 124, 223

Shacklete, H.T. 25

Shaikh, Z.A. 45, 93, 223

Shanholtz, V.0. 27

Shapiro, J . 157

Shapiro, M.A. $32,50,63,68,96$, 144,206

Sharenkova, K. 46, 179

Shaw, D. 13 


\section{AUTHOR INDEX (Contd.)}

Shaw, T.L. $46,111,124$

Shaw, W.H.R. 46, 124

Shay, D.E. 31,63

Shealey, M.H., Jr. 175

Shearer, R.E. 46, 66

Sheets, W.D. $36,46,81$

Sheridan, J.R. $46,66,188$

Shields, J. 43, 103, 122,134

Shuettle, K.H. 46

Shukla, S.S. 46,152

Shultz, C.D. 174

Shumway, S.E. 134

Shurben, D.G. 13,111, 131, 190

Shurben, D.S. 72, 132, 136, 216

Shurbern, D.S. 27

Shurin, A.T. 132, 156

Shuster, C. 46

Sick, L.B. 46, 93, 175

Siesennop, G.D. 7, 98, 130

Sigel, H. 46

Sigler, W.F. 136, 137

Sigmon, C.F. 175

Sikora, R.A. $56,153,183,189,193$

Silaichuk, E.V. 46, 104, 129

Silleck, R.E. 16

Sills, J.B. 5, 96

Silver, S. 176

Silverberg, B.A. 93

Sins, K.R. 47

Singer, P.C. 47,74

Singh, S.B. $47,67,74,134,188$, 202,206

Sinha, E. 5, 47

Sinley, J.R. 140, 223

Sittler, B. 168

Sizemore, D.R. 28, 47,62, 66, 205

Skidmore, J.F. 224

Skidmore, w.J. 47, 74, 202

Skogerboe, R.K. 51, 52

Skrapek, K. 193

S1 ater, J.V. 107, 224

Slatkin, D. 47

Slonim, A.R. $47,80,140$

Slonim, C.B. $47,80,140$

Sma11, L.F. 224

Smart, G. 74

Smith, A.L. 175

Smith, B.D. 93

Smith, E.J. 47, 50,68, 96, 144, 206

Smith, L.E. 191

Smith, L.L. 201, 202
Smith, L.L., Jr. 7, 44, 98, 103, $129,130,183,201,202$

Smith, M.W. 124,134

Smi.th, O.R. 206

Smith, R.T. 130

Smith, R.W. 47, 66

Smyly, W.J.P. 119

Snyder, C.B. 147

Snyder, H.G. 147

Sobsey, M. 74

Sodergren, S. 47, 107, 124, 144, $176,182,224$

Sollmann, T. 193

Sonis, S. 29, 149

Sonntag, N.C. 176

Soremark, R. 208

Sorensen, E.M.B. 78, 79

Southgate, C.A. 130

Spangler, W.J. 176

Sparks, R.E. 48,66,96, 188, 224

Sparrow, B.W. $18,113,162$

Spaulding, W.M., Jr. 10,48

Spehar, R.L. $48,93,225$

Speranza, A.W. 225

Sperling, K.R. .94, 135

Spooner, G.M. 200

Spoor, W.A. 114

Sprague, J.B. 22, 44, 48, 49, 115, $123,124,190,217,223,225$

Sprague, R.W. 81

Sreenivasah, A. 225

Srna, R.F. 71

Stainton, M.P. 8, 98, 108, 141, 145, 155,209

St andbury, F.A. $8,108,158$

St anley, R.A. 49

Starkey, R.L. 144

Stebbing, A.R.D. 49

Steemann Nielsen, E. 125

Steffens, W: 74

Stein, A. 193

Stein, J.N. 49, 152, 225

Steinnes, E. 9

Stephen, C.E. 121

Stewart, G.L. 108

St ewart, J.E. 137

Stewart, J.G. 152

Stiemke, R.E. 68,188

Stiles, W. 49

Stocks, J. 20 
AUTHOR INDEX (Contd.)

Stokes, P.M. 36, 49, 64, 74, 96, $125,171,182,187$

Stokes, K.M. 101

Stom, D.I. 193

Strik, J. 104

Struckmeyer; B.E. 113,142

Stupka, R.C. 152

Styron, C.E. 135

Sudo, R. 49, 104,125

Sullivan, G.W. $14,49,50,84,99$, $105,111,140,146,160,180,197$, 212,226

Sullivan, J. 50,112

Summers, A.0. 176

Sund $a$, W. 125

Surber, E.W. $50,79,104,125,130$

Swader, J.A. 112

Sykora, J.L. $32,47,50,63,68,96$, 144,206

Synak, M. 50, 68, 96, 144, 206

Tabata, K. 38, 50, 93, 94, 106, 107 , $121,125,126,140,182,194,199$, 226

Tabity, F.R. 34

Taimi, K.L. 161

Takabatake, E. 163

Tarao, R. 176, 206

Tarzwe11, C.M. 50, 51, 76, 80, 152, 179,208

Taylor, D. 51, 94, 176

Tchobanoglous, G. 71

Tebo, L.B., Jr. 206

Teeter, J.W. 135

Terhaar; C.J. 51

Th at cher, T.0. 9, 115

Thomann, R.V. 94

Thomas, A. 51

Thomas, W.H. 126

Thompson, J.A.J. 81

Thormann, D. 51, 94, 152

Thorp, V.J. $51,89,94,226$

Thurberg, F.P. 35, 51, 94, 126, 135, 198

Thurston, R.V. 40, 51, 52, 67, 121 , 133,187

Till ander, M. 106

Tiller, B.A. 13,70, 137, 190, 212

Tkachenko, V.N. 52

Toetz, D.W. 75
Tomiyama, T. 29, 188

Tomk iewicz, S.M., Jr.

Tomoyeda, M. 52, 176

Tompkins, T. 176

Tonomura, K. 164

Tovel1, P.W.A. 224

Trabalka, J.R. 104

Trama, F.B. 96, 104, 105, 135, 188, $193,194,199$

Trojnar, J.R. 140,188

Trollope, D.R. 52, 126, 144, 153, 182,226

Trussel, R.P. 75,188

Tsai, S.-C. 176, 188

Tupholme, C.H.S. 130

Turbak, S. 39

Turnbul1-Kemp, P. St. J. 126

Turnbul1, H. 53, 81, 105, 153

Turner, R.R. 176

Turner, W.R. 53

U.S. Department of the Interior 5, $6,53,79,105,126,153,154$, $157,177,226$

U.S. Environmental Protection Agency $6,53,81,153,182,196,208$

U.S. Federal Water Pollution Control Administration 53

Ueda, K. 178

Ui, J. 177

Ukeles, R. 53

Ukita, T. 166

Underwood, G. 23, 148

Uspenskaya, N.Y. 189

Uthe, J.F. 177

Uysal, H. 24

Uyttersprot, G. 41

Vaccaro, R.F. 126

Vamos, R. 74

Van Hook, R.I. 53

Van Loon, J.C. 53, 126, 226

Van Winkle, W., Jr. 135

VanDyke, J.M. 27, 72, 116, 191, 216

VanLoon, J.C. 9, 59

Varanasi, U. 53, 153, 177

Vaughan, B.E. 53

Ventilla, R.J. 25, 149, 164

Vermeer, K. 177 
AUTHOR INDEX (Contd.)

Vernberg, F.J. 54

Vernberg, W. B. 94, 135, 162, 177

Veselov, E.A. 135

Vesta1, J.R. 34

Vigor, W.N. 221

Wurty, A. 81

Wurtz, C.B. 227

Yager, C.M. 57

Yamada, S.B. 211

Yamagawa, A. 188

Yamanaka, S. 178

Yasunaga, Y. $57,76,178,189,193$, 201

Yasutake, W.T 158

Yevich, P.P. 87, 109

Yocum, T.W. 55

Yoh, L. 118

Yoshi i, G. 57, 97, 200, 203

Young, M.K. 102

Young, M.L. 57, 144, 227

Young, R.G. 57, 127, 198

Young, R.T. 68, 136, 140

Zavodnik, N: 154

Zehmp fenning; R.G. 105, 130

Zeller, H.D. 178

Zellmer, S.D. 45

Ziebe11, C.D. 203, 207

Zitko, v. $32,57,66,95,127,140$,

$141,207,228$ 
Distribution for ANL/EMR-5

\section{Interna1:}
J. E. Bogner
R. P. Carter
E. J. Croke
L. K. Daniels
T. F. Daniels
D. E. Edgar
J. G. Ferrante
R. M. Goldstein
P. F. Gustafson
W. Harrison
R. J. Henning
J. D. Henricks
R. R. Hinchman
R. H. Huebner
D. O. Johnson
A. B. Krisciunas
K. S. Macal
C. A. Malefyt
W. E. Massey
R. D. $01 \operatorname{sen}(50)$
J. I. Parker
E. G. Pewitt
J. J. Roberts
W. K. Sinclair
A. A. Sobek
R. W. Vocke
W. S. White
ANL Contract File
ANL Libraries (5)
TIS Files (6)

\section{External:}

DOE-TIC, for distribution per UC-11 (240)

Manager, Chicago Operations and Regional office, DOE

Chief, Office of Patent Counsel, DOE-CORO

President, Argonne Universities Association

Energy and Environmental Systems Division Review Committee:

E. E. Angino, U. of Kansas

R. E. Gordon, U. of Notre Dame

W. W. Hogan, Harvard U.

L. H. Roddis, Jr., Charleston, S.C.

G. A. Rohlich, U. of Texas, Aust in

R. A. Schmidt, Booz, Allen, \& Hamilton

C. R. Adams, Kentucky Dept. of Natural Resources, Frankfort

J. Adams, Florence \& Hutcheson, London, Ky.

A. B. Agnew, U.S. Geological Survey, Reston, Va.

A. F. Agnew, Library of Congress, Washington, D.C.

E. Aldon, Rocky Mountain Forest Experiment Station, Albuquerque, N.M.

S. R. Aldrich, U. of Illinois, Urbana

C. Anderson, Iowa State University, Ames

P. N. Angel, Madisonville Community College, Ky.

R. Armstrong, U.S. Corps of Engineers, Cincinnati, Ohio

C. R. Arnold, Southern Illinois University, Edwardsville

S. I. Auerbach, Oak Ridge National Lab.

D. Bailey, Wyoming Dept. of Environmental Quality, Cheyenne

S. Baldwin, Westmoreland Coal Company, Tams, W.Va.

H. Barem, U.S. Dept. of Agriculture, Washington, D.C.

R. I. Barnhise1, U. of Kentucky, Lexington

J. Barse, U.S. Dept. of Agriculture, Washington, D.C.

R. Barth, Colorado School of Mines, Golden

C. Barton, Miller, Wilbry and Lee, Nashville, Tenn.

D. C. Bayha, U. of Kentucky, Lexington

F. Beal, Illinois Inst. of Natural Resources, Chicago

C. A. Beasley, Office of Surface Mining, Region I, Charleston, W.Va.

J. C. Beatley, U. of Cincinnati, Ohio

G. Beech, Wyoming Dept. of Environmental Quality, Cheyenne

H. W. Beemer, U. S. Army Corps of Engineers, Cincinnati, Ohio 
R. E. Behling, West Virginia U., Morgantown

W. A. Berg, Colorado State U., Fort Collins

J. Blackburn, Office of Surface Mining, Knoxville, Tenn.

J. Block, Illinois Dept. of Agriculture, Springfield

R. W. Bollinger, Tennessee Valley Authority, Norris

E. Bolter, U. of Missouri - Rolla

J. Bonta, U.S. Dept. of Agriculture, Coshócton, Ohio

K. Bowden, Northern Illinois U., DeKalb

K. C. Bowling, Interstate Mining Compact Commission, Lexingtion, Ky:

S. Boyce, U.S. Geological Survey, Reston, Va.

J. Boyer, Bituminous Coal Research, Inc., Monroeville, Pa.

L. E. Brandenburg, Kentucky. Bureau of Surface Mining and Reclamation Enforcement, Frankfort.

J. Breaden, U.S. Army Corps of Engineers, Washington, D.C.

E. Brett, Natural Resources Center, University, Ala.

R. Brooks, Peter Kiewit Sons.' Co., Sheridan, Wyo.

A. P. Brown, Illinois Dept. of Conservation, Springfield

R. S. Brundage, Peabody Coal Co., Columbia, Mo.

H. E. Brown, U.S. Dept. of Agriculture, Washington, D.C.

W. R. Brynes, Indiana Dept. Forestry \& Natural Resources, W. Lafayette

E. R. Buckner, U. of Tennessee, Knoxville

L. H. Burke, Northrup King Co., Bulan, Ky.

A. Bush, W. Kentucky U., Bowling Green

H. Buxton, U. of South Carolina, Columbia

D. W. Byerly, U. of Tennessee, Knoxville

P. Cain, Virginia Div. of Mined Land Reclamation, Big Stone Gap

D. Calhoun, U.S. Dept. of Interior, Denver, Colo.

C. Call, Ohio Dept. of Natural Resources, Columbus

J. L. Calver, Virginia Div. of Mineral Resources, Charlottesville

J. P. Capp, Morgantown Energy Research Center, W.Va.

E. A. Carr, Tennessee Div. of Soil Conservation, Norris

J. E. Carrell, U. of Missouri - Columbia

D. Carson, Consolidation Coal Co., Evansville, Ind.

D. P. Carter, NERCO, Inc., Portland, Ore.

L. Casey, U.S. Forest Service, Broomali, Pa.

F. Charton, Roane State Community College, Harriman, Tenn.

S. Clark, St. George, Kan.

R. Clusen, U.S. Dept. of Energy, Washington, D.C.

W. K. Coblentz, U.S. Dept. of Energy, Washington, D.C.

E. Colburn, Texas A\&M U., College Station

D. Coleman, Colorado State U., Fort Collins

H. R. Collins, Ohio Dept. of Natural Resources, Columbus

J. B. Comer, U. of Tulsa, Okla.

W. Cook, Colorado State U., Fort Collins

R. Corbett, U. of Akron, Ohio

R. E. Corcoran, U.S. Bureau of Mines, Washingțon, D. C.

R. M. Cox, University, Ala.

G. A. Crabb, U.S. Dept. of Interior, Washington, D. C.

D. Crane, U.S. Dept. of Interior, Denver, Colo.

E. Crolkosz, University Park, Pa.

D. B. Crouch, Utah International, Inc., San Francisco, Calif.

J. A. Curry, Tennessee Valley Authority, Norris

W. R. Curtis, Northeastern Forest Experiment Station, Berea, Ky.

G. D'Allesio, U.S. Environmental Protection Agency, Washington, D.C. 
R. C. Dahlman, U.S. Dept. of Energy, Washington, D.C.

W. S. Dancer, U. of Illinois, Urbana

T. W. Daniel, Jr., Geological Survey of Alabama, University, Ala.

S. Darby, Georgia Div. of Environmental Protection, Macon

R. L. Darneal, U.S. Dept. of Energy, Washington, D.C.

G. Davis, Surface Environment and Mining Program, Billings, Mont.

W. H. Davidson, Surface Mined Area Restoration Research Project, Kingston, Pa.

J. Dearing, West Central Illinois Valley Regional Planning Comm., Carlinville

G. P. Dempsey, U.S. Forest Service, Princeton, W.Va.

D. G. Deveraux, Northern Energy. Resources Co., Portland, Ore.

G. Dials, Mining \& Reclamation Council of America, Washington, D.C.

B. Dickerson, IJ.S. Dept of Agriculture Forest Service, Morgantown, W.Va.

P. Dittberner, Western Energy \& Land Use Team, Fort Collins, Colo.

D. Donner, U.S. Bureau of Mines, Denver, Colo.

J. Dowe1l, Gulf State Paper Co., Tuscaloosa, Ala.

T. E. Dudley, The North American Coal Corporation, Bismarck, N.D.

D. Duster, Business \& Economic Development, Springfield, I11.

D. Dwyer, Utah State U., Logan

D. T. Eagle, Tennessee Dept. of Conservation, Norris

L. Eddleman, U. of Montana, Missoula

B. Edelston, Charles River Assoc., Cambridge, Mass.

M. Edwards, Lothian Regional Council, Edinburgh, Scotland

R. B. Erwin, West Virginia Geological \& Economic Survey, Morgantown

F. Evans, Geological Survey of Alabama, University, Ala.

K. Evans, NALCO Environmental Sciences, Northbrook, I11.

D. Everhart, International Minerals \& Chemical Corp., Libertyville, Ill.

B. Evilsizer, Illinois Dept. of Mines \& Minerals, Springfield

K. R. Faerber, S. Charleston, W.Va.

D. S. Fanning, U. of Maryland, College Park

J. H. Farber, National Ash Association, Washington, D. C.

L. Felde, Miller, Wilbry and Lee, Louisville, Ky.

J. Farrell, Allied Chemical, Jamesville, N.Y.

S. Fitzgerald, U.S. Dept. of Energy, Washington, D.C.

W. J. Fogarty, Jr., Old West Regional Commission, Billings, Mont.

R. F. Follett, U.S. Dept. of Agriculture, Beltsville, Md.

C. S. Fore, Oak Ridge National Lab.

K. Foster, U. of Arizona, Tucson

R. C. Fountain, Winter Haven, Fla.

T. G. Frangos, U.S. Dept. of Energy, Washington, D.C.

S. Frank, Economic Regulatory Commission, Washington, D.C..

R. Franklin, U.S. Dept. of Energy, Washington, D.C.

J. R. Freeman, Sturm Environmental Services, Bridgeport, W.Va.

A. Fry, Energy Resources Co., Inc., Washington, D. C.

W. H. Fuller, U. of Arizona, Tucson

S. Gage, U.S. Environmental Protection Agency, Washington, D.C.

C. H. Gaum, U.S. Army Corps of Engineers, Washington, D.C.

J. H. Gibbons, Office of Technology Assessment, Washington, D.C.

0. J. Gibson, Illinois Coal Operators Assoc., Springfield, Ill.

F. Glover, Morgantown, W.Va.

L. Glover, Virginia Dept. of Geological Sciences, Blacksburg

J. L. Gober, Tennessee Valley Authority, Knoxville

M. Gottlieb, U.S. Dept. of Energy, Washington, D.C.

J. Goris, U.S. Bureau of Mines, Spokane, Wash.

A. F. Grandt, Peabody Coal Co., St: Louis, Mo. 
E. Graves, U.S. Army Corps of Engineers, Washington, D.C.

B. B. Green, NERCO, Inc., Portland, Ore.

L. 0. Greene, Div. of Operations \& Enforcement, Madisonville, Ky.

F. Gregg, U.S. Bureau of Land Management, Washington, D.C.

R. Gregory, Montana State U., Bozeman

S. Grogan, Utah International, Inc., Fruitland, N. Mex.

A. Grosboll, Abandoned Mined Land Reclamation Council, Springfield, Ill.

C. Grua, U.S. Dept. of Energy, Washington, D.C. (3)

J. L. Guernsey, Indiana State U., Terre Haute

F. Guiher, U.S. Army Corps of Engineers, Cincinnati, Ohio

J. Gulliford, Iowa State U., Ames.

L. Hardin, Illinois Dept. of Mines \& Minerals, Springfield

G. Harris, U.S. Environmental Protection Agency, Cincinnat1, Ohio

B. Hawkins, Reclamation Services; Inc., Lakeland, Fla.

H. A. Hawthorne, General Electric Corp., Santa Barbara, Calif.

T. G. Healy, Morrison-Knudsen Co., Botse, Idaho

W. N. Heine, Office of Surface Mining, Washington, D.C.

S. Henning, Iowa State U., Ames

C. Henry, U. of Texas, Austin

R. E. Hershey, Tennessee Dept. of Conservation, Nashville

R. H111, U.S. Environmental Protection Agency, Cincinnat1, Ohio

W. T. Hinds, Battelle Pacific Northwest Lab.; Richland, Wash.

R. Hodder, Montana State U., Bozeman

H. Hollister, U.S. Dept. of Energy, Washington, D.C.

G. Hollett, Virginia Dept. of Conservation \& Economic Development, Big Stone Gap

R. W. Holloway, Southwestern Illinois Coal Corp., Percy

G. V. Holmberg, U.S. Dept. of Agriculture, Washington, D.C.

M. Homec, California Energy Commisston, Sacramento

W. C. Hood, Southern Illinois U., Carbondale

L. R. Hossner, Texas A\&M U., College Station

P. M. Howard, Greenwood Land \& Mining, Somerset, Ky.

R. C. Howe, Indiana State U., Terre Haute

R. T. Huffman, U.S. Army Corps of Engineers, Vicksburg, Miss.

E. Hughes, Montana Bureau of Land Management, Billings.

R. J. Hutnik, Pennsylvania State U., University Park

W. Hynan, National Coal Association, Washington, D.C.

E. Imhoff, Office of Surface Mining, Indianapolis, Ind.

M. T. Janis, Office of Management and Budget, Washington, D.C.

I. J. Jansen, U. of Illinois, Urbana

I. P. Jenkins, Mining Ventures, Shell 0il Co., Houston, Tex.

D. O. Johnson, Gas Research Institute, Chicago, I11.

T. Johnson, Local Government Affairs, Springfield, I11.

D. Jones, Office of Surface Mining, Kansas City, Mo.

J. R. Jones, Peabody. Coal Co., St. Louis, Mo.

L. M. Kaas, U.S. Bureau of Mines, Washington, D.C.

R. Kail, Jim Bridger Mining Co., Wyo.

D. E. Kash, U.S. Geological Survey, Reston, Va.

D. Kenney, Illinois Dept. of Conservation, Springfield

W. Klimstra, Southern Illinois U., Carbondale

C. Kolar, Southern Illinois U., Carbondale

E. W. Kruse, U.S. Dept. of Energy, Washington, D.C.

J. Lang, U. of Wisconsin, Madison

D. Larsen, Interagency Task Force, Salt Lake City, Utah 
L. Leistritz, Texas A\&M, College Station

S. S. Leung, Eastern Kentucky U., Richmond

D. W. Lewandowski, Purdue U., W. Lafayette

T. C. Linsey, Southern Illinois U., Carbondale

W. Long, Long Pit Mining Co., Knoxville, Tenn.

P. Loquercio, Illinois Institute of Natural Resources, Chicago

H. L. Lovel1, Pennsylvania State U., University Park

R. Lowrie, U.S. Dept. of Interior, Kansas City, Mo.

E. S. Lyle, Jr., Alabama Dept. of Forestry, Auburn

P. Lynch, Illinols Environmental Protection Agency, Springfield

D. McAllister, U. of California, Los Angeles

H. McCammon, U.S. Dept. of Energy, Washington, D.C.

P. M. McClain, Skelly \& Loy, Harrisburg, Pa.

C. McKe11, Utah State U., Logan

C. McKenzie, North Carolina Dept. of Natural \& Economic Resources, Raleigh

W. McMartin, North Dakota State U., Fargo

R. McNabb, Office of Surface Mining, Indianapolis

L. McNay, Office of Surface Mining, Washington, D.C.

R. D. McWhorter, Colorado State U., Fort Collins

J. Maddox, Office of Surface Mining, Knoxville, Tenn.

R. J. Major, AMAX Coal Co., Indianapolis, Ind.

C. R. Malone, National Research Council, Washington, D.C.

D. R. Maneval, Office of Surface Mining, Washington, D.C.

J. Markley, Office of Surface Mining, Washington, D.C.

W. T. Mason, Jr., U.S. Fish \& Wildlife Service, Harpers Ferry, W.Va.

S. Massie, Abandoned Mined Land Reclamation Council, Springfield, I11.

C. D. Másters, U.S. Geological Survey, Reston, Va.

M. Mauzy, Illinois Environmental Protection Agency, Springfield

D. Maxfield, Northern Illinois U., DeKalb

C. Medvick, Illinois Dept. of Mines \& Minerals, Marion

D. C. Mellgren, U.S. Dept. of Interior; Elkins, W.Va.

C. Messick, U.S. Dept. of Interior, Washington, D.C.

E. V. Miller, U.S. Dept. of Agriculture, Washington, D.C.

J. R. Miller, U. of Maryland, College Park

R. A. Minear, U. of Tennessee, Knoxville

J. H. Moeller, Arch Mineral Corp., St. Louis, Mo.

D. Moore, U.S. Geological Survey, Denver, Colo.

J. R. Moore, U. of Tennessee, Knoxville

J. Morgan, U.S. Dept. of Interior, Washington, D.C.

M. Morin, Southern Illinols U., Carbondale

R. Morris, Harvest Publishing Co., Cleveland, Ohio

W. Mott, U.S. Dept. of Energy, Washington, D.C.

J. Mullan, National Coal Association, Washington, D.C.

R. Murphy, Illinols Capital Development Board, Springfield

J. R. Nawrot, Southern Illinois U., Carbondale

R. Neas, Western Illinois U., Macomb

R. Neuenschwander, Missour1 Dept. of Natural Resources, Jefferson City

D. Novick, Lester B. Knight, Chicago, IIl.

M. A. Oates, T. K. Jessup, Inc., Greenville, Ky.

J. J. O'Toole, Iowa State U., Ames

R. J. Olson, Oak Ridge National Lab.

W. S. Osburn, Jr., U.S. Dept. of Energy, Washington, D.C.

M. E. Ostrom, State Geologist of Wisconsin, Middleton

D. E. Overton, U. of Tennessee, Knoxville 
J. Paone, U.S. Dept. of Interior, Washington, D.C.

D. Parkinson, U. of Calgary, Alberta

E. Pasch, U.S. Fish and Wildlife Service, Kearneysville, W.Va.

J. Patterson, Ecological Services Lab., Washington, D.C.

R. Payne, Railroad Commission of Texas, Austin

E. D. Pentecost, Office of Surface Mining, Kansas City, Mo.

C. H. Percy, U.S. Senator, Springfield, Ill.

J. C. Perkowski, Petro Canada, Calgary, Alberta

A. 0. Perry, office of Surface Mining, Indianapolis, Ind.

G. Petsch, Ruhr Regional Planning Authority, West Germany

G. J. Phillips, Consolidation Coal Co., Evansville, Ind.

J. E. Pitsenbarger, West Virginia Dept. of Natural Resources, Charleston

W. T. Plass, U.S. Forest Service, Princeton, W.Va.

L. R. Pomeroy, U. of Georgia, Athens

R. L. Powell, Bloomington, Ind.

J. Power, U.S. Agricu1tural Research Service, Mandan, N.D.

M. Price, U.S. House of Representatives, Washington, D.C.

J. Pugliese, U.S. Bureau of Mines, St. Paul, Minn.

S. Rebuck, Maryland State Bureau of Mines, Westernport

J. Reed, Peter Kiewit Sons' Co., Omaha, Nëb.

F. B. Reeves, Colorado State U., Fort Collins

P. Reeves, Office of Surface Mining, Washington, D.C.

J. A. Reinemund, U.S. Geological Survey, Reston, Va.

V. Ricca, Ohio State U.; Columbus

C. W. Rice, U. of Kentucky, Lexington

W. H. Rickard, Battelle Pacific Northwest Lab., Richland, Wash.

H. Runkle, BLM-EMRIA, Denver, Colo.

W. Sander, Illinois Economic \& Fiscal Commission, Springfield

F. Sandoval, U.S. Dept. of Agriculture, Mandan, N. Dak.

R. L. Sanford, U. of Wisconsin, Platteville:

D. P. Satche11, Southern Illinois U., Carbondale

R. H. Sauer, Battelle Pacific Northwest Lab., Richland, Wash.

G. W. Saunders, U.S. Dept. of Energy, Washington, D.C.

W. M. Schafer, Montana State U., Bozeman

W. B. Schmidt, U.S. Dept. of Energy, Washington, D.C.

T. C. Scott III, Southern Illinois U., Carbondale

W. D. Seitz, U. of Illinois, Champaign

J. C. Sencindiver, West Virginia U., Morgantown

L. V. A. Sendlein, Southern Illinois U., Carbondale

M. Shawhickerson, Orphan Land Reclamation, Nashville, Tenn.

R. Sheridan, U. of Montana, Missoula

D. C. Short, Office of Surface Mining, Knoxville, Tenn.

P. L. Sims, Agricultural Research Service, Woodward, Okla.

B. W. Sindelar, Montana State U., Bozeman

J. W. Skehan, Boston College, Weston, Mass.

D. H. Slade, U.S. Dept. of Energy, Washington, D.C.

E. Smith, Consolidation Coal Co., Evansville, Ind.

G. E. Smith, Inst. for Mining \& Minerals Research, Lexington, Ky.

J. M. Smith, Yara Engineering Corp., Sandersville, Ga.

M. J. Smith, U.S. Dept. of Interior, Washington, D.C.

M. Smith, U.S. Dept. of Interior, Washington, D.C.

G. A. Smout, Consolidation Coal Co., Pinckneyville, I1l.

G. Smrikarov, Mathtech, Inc., Princeton, N.J.

A. A. Socolon, Pennsylvania Dept. of Environmental Resources, Harrisburg 
S. T. Sorrell, Phillips Coal Co., Dallas, Tex.

W. E. Sowards, Utah International, Inc., San Francisco, Calif.

S. Stafford, Indiana Dept. of Natural Resources, Indianapolis

A. E. Stevenson, U.S. Senator, Old Senate Office Building, Washington, D.C.

R. Stewart, U.S. Fish \& Wildlife Service, Washington, D.C.

R. Strode, Consolidation Coal Co., Norris, Ill.

J. Sturm, Sturm Environmental Services, Bridgeport, W.Va.

H. Stutz, Brigham Young U., Provo, Utah

R. E. Sundin, Wyoming Dept. of Environmental Quality, Cheyenne

P. Sutton, OARDC, Caldwell, Ohio

J. Swinebroad, U.S. Dept. of Energy, Washington, D.C.

J. Tavares, National Research Council, Washington, D.C.

G. S. Taylor, Ohio State U., Columbus

J. Thames, U. of Arizona, Tucson

J. R. Thompson, Governor, Springfield, Ill.

R. V. Thurston, Montana State U., Bozeman

C. T. Trott, Northern I1linois U., DeKalb

W. Tucker, Tennessee Dept. of Conservation, Nashville

M. K. Udall, U.S. House of Representatives, Washington, D.C.

J. VanderWalker, U.S. Dept. of Interior, Fort Coll1ns, Colo.

J. Vimmerstedt, OARDC, Wooster, Ohio

K. C. Vories, Morrison-Knudsen, Inc., Boise, Idaho

G. Wagner, U. of Missouri - Columbia

M. Wallace, Texas Railroad Commission, Austin

R. Warder, National Science Foundation, Washington, D.C.

R. L. Watters, U.S. Dept. of Energy, Washington, D.C.

K. Weaver, Johns Hopkins U., Baltimore, Md.

V. L. Whetzel, West Virginia U., Morgantown

D. P. Wlener, Research - INFORM, New York, N.Y.

C. E. Wier, AMAX Coal Co., Indianapolis, Ind.

G. Wilmhoff, U. of Kentucky, Lexington

J. H. Wilson, U.S. Dept. of Energy, Washington, D.C.

J. E. Winch, Canadian Land Reclamation Assoc., Guelph, Ontario

V. P. Wiram, AMAX Coal Co., Indianapolis, Ind.

G. H. Wood, U.S. Geological Survey, Reston, Va.

M. Wood, South Carolina Land Resource Conservation Commission, Columbia

R. A. Wright, West Texas State U., Canyon

J. Yancik, National Coal Assoc., Washington, D.C.

H. Yocum, AMAX Coal Co., Indianapolis, Ind.

T. G. Zarger, Tennessee Valley Authority, Norris, Tenn. 